\title{
بعض قيم التسامح في الفكر التربوي الإسلامي \\ وكيفية تعزيزها داخل الجامعات المصرية لمواجهة العنف المجتمعي
}

إعــــداد

$$
\text { د / آمال محمد إبراهيه }
$$

مدرس بقسم أصول التربية

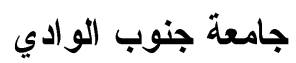

$$
\text { مدرس بقسم أصول التربية أحمد فؤاد }
$$


بعض قيم التسامح في الفكر التربوى الاسلامى وكيفية تعزيزها داخل الجامعات المصرية لمواجهة العنف المجتمعى آمال

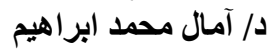

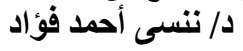

\section{بعض قيه التسامح في الفكر التربوي الإسلامي وكيفية تعزيزها داخل الجامعات المصرية لمواجهة المنف المجتمفي}

\section{د / آمال محمدل إبراهيي}

د / نتسي أحمد فؤاد

المستخلص: - (الص:

تهدف الدر اسة إلي الكثف عن مفهوم التسامح و العقبات التي تقف حائلاً في سـبـيل

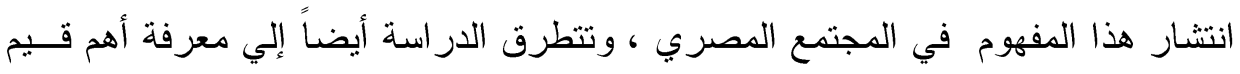

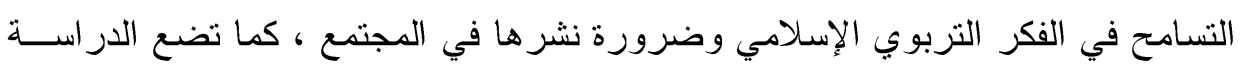

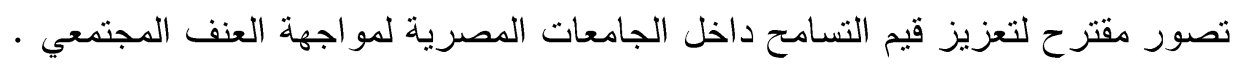

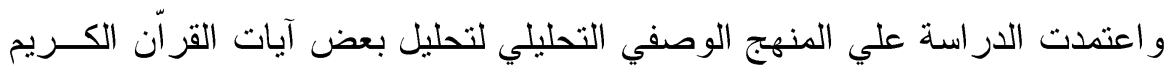

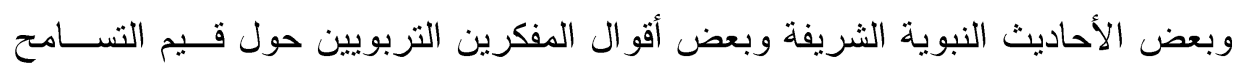

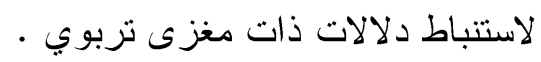

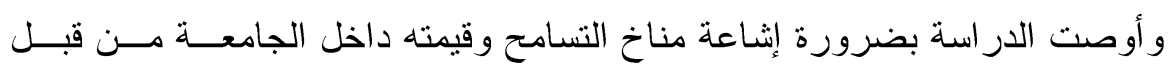

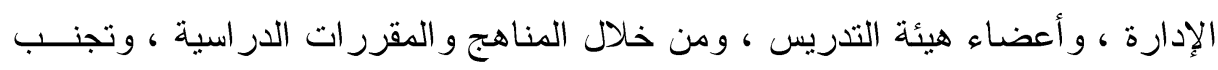

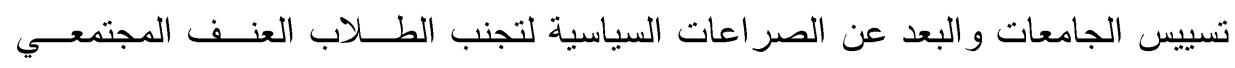
و الفوضى الفكرية ، و انهيار منظومة القيم الأخلاقية .

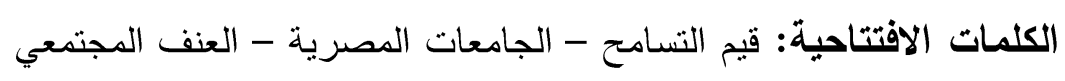


بعض قيم التسامح في الفكر التربوى الاسلامى وكيفية تعزيزها داخل الجامعات المصرية لمواجهة العنف المجتمعى د/ آمال محمد ابر اهيم المهن

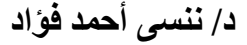

\title{
Some values of tolerance in the Islamic educational thought and how to strengthen them within the Egyptian universities to confront community violence
}

\author{
Dr. Nancy Ahmed fouad
}

Dr. Amal Mohamed Ibrahem

\begin{abstract}
:
Some registry values in educational thought Islamic and how to strengthen it. within the Egyptian universities to address community violence. The study aims to reveal the concept of tolerance and the obstacles standing in the way of the spread of this concept in the Egyptian society, the unfinished study also advertises the most important values of tolerance in the Islamic Educational thought and published in the community. It also study imagine a proposal to promote the values of tolerance within universities airline to face repressive violence. on the descriptive approach adopted analytical study to analyze some of the verses of the Qur'an and the hadith Sharif and some of the sayings of educational THINKERS on the values of tolerance to develop meaningful indications .

and recommended study of the need to foster a climate of tolerance and value within the links by Committee members in fldc through school curricula, presidential statements and avoid the politicization of the scholastic universities and avoiding conflicts transmits to avoid students community violence and chaos the intellectual collapse of moral values .
\end{abstract}

Keywords:- the value of the registry - Egyptian universities community violence 


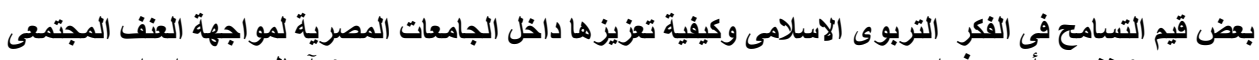
د/ آمال محمد ابر اهيم المنف المجنم

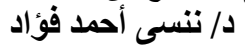

\section{مقدمة}

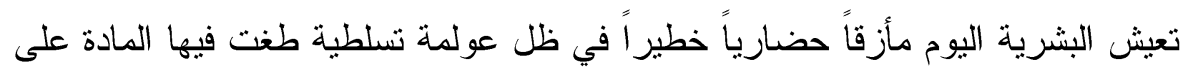

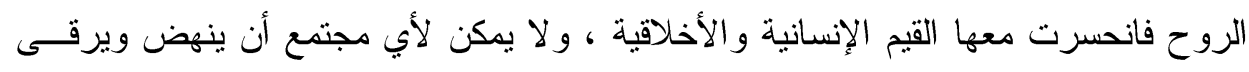

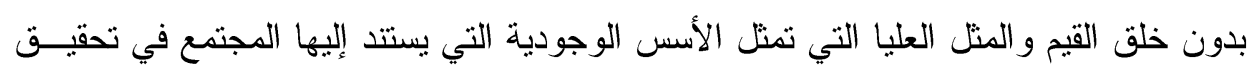

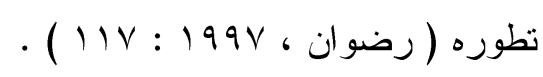

وباستقر اء موضوعي لتاريخ المجتمعات ، يتضح أن المجتمع الإسلامي هو المجتمع الذي

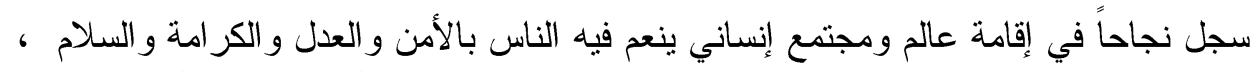

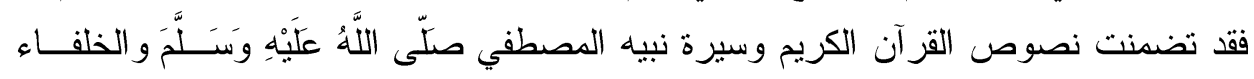

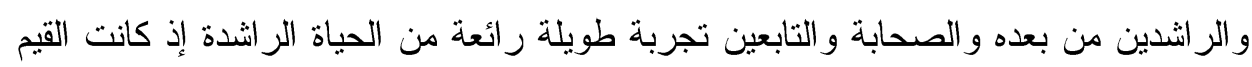

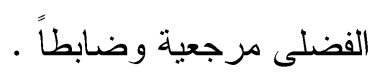

وقد ظهر في المجتمع المصري الآن نتيجة التخلي عن الكثير من المبادئ والقيم والتي

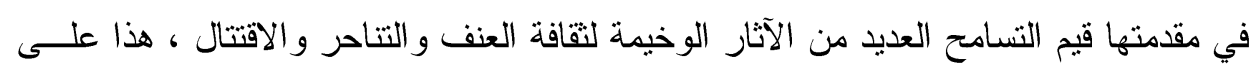

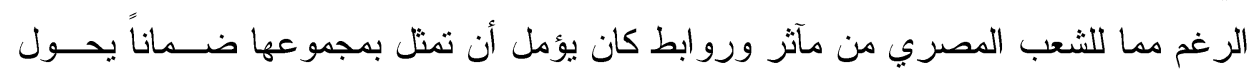

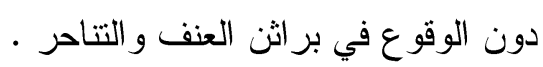
وبما أن مواجهة العنف و التسلط لا بمكن أن تأني عبر القرارات و القو انين النافذة ، و إنما

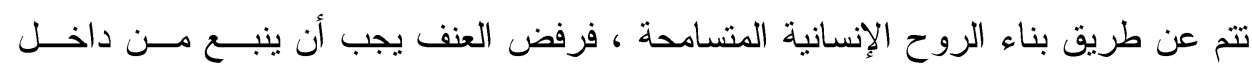

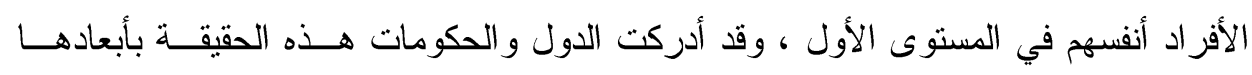

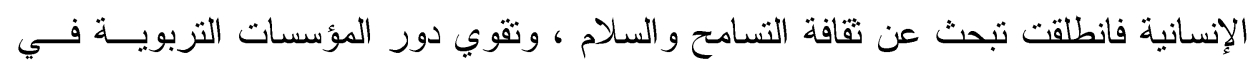
تأصيل قيم التسامح ومعانيه في نفوس أفر ادها .

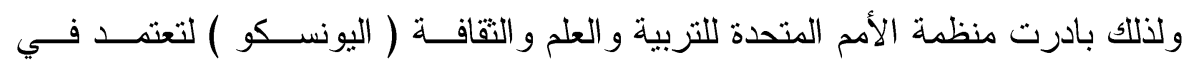
مؤتمرها العام في دورته الثامنة والعشرين في السادس عشر من نوفمبر للعام 1990 م م إعلان

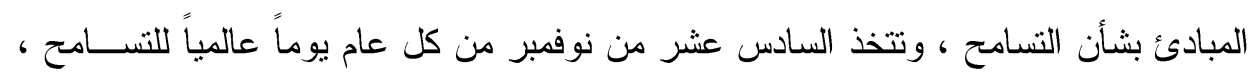

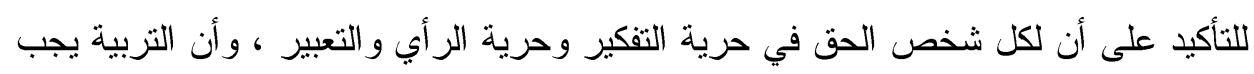

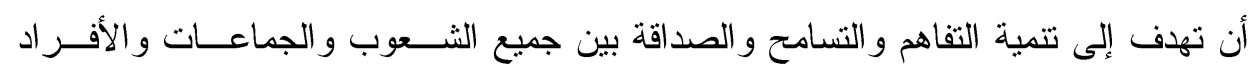

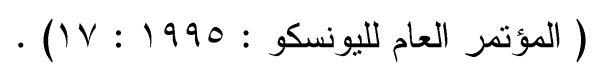

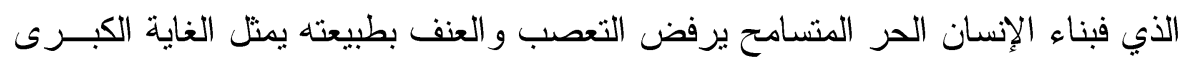

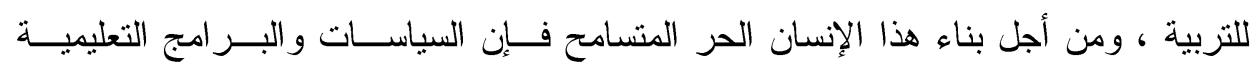

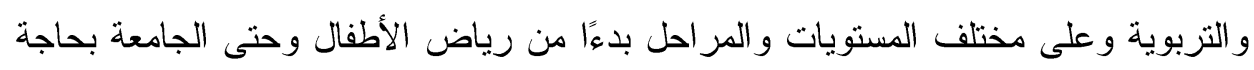

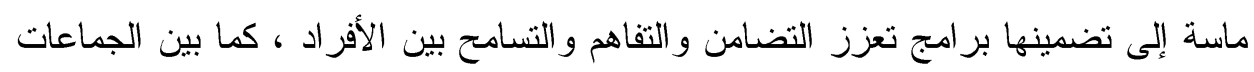


بعض قيم التسامح في الفكر التربوى الاسلامى وكيفية تعزيزها داخل الجامعات المصرية لمواجهة العنف المجتمعى

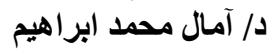

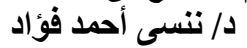

و المجتمعات على ما بينها من تباين واختلاف طبيعي وكوني ( عبد الحميد حسن الحسارث : . ( r...V

وحيث أن الجامعات من أهم مؤسسات إعداد وتأهيل الكو ادر البشرية ، إلى جانب قدرتها

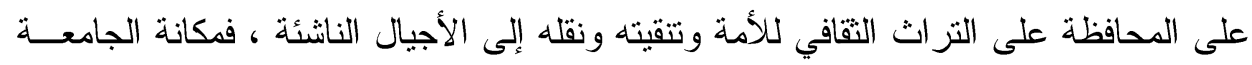

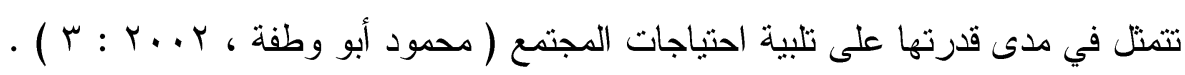

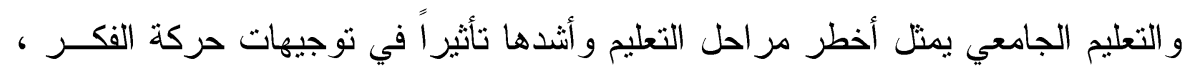
لأن الجامعات تنتقطب مجتمع الثباب الذين سيشكلون في المستقبل النخبة المثقفة ، القيادية ،

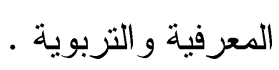

يتضح مما سبق ضرورة تكثيف الجهود وتتظيمها في الوسط الجامعي لتنتـــئة الطلبـــة و الطالبات على قيم التسامح حتى تنتقل هذه القيم من خلالها إلى المجتمع بأكمله وخاصة " أننا

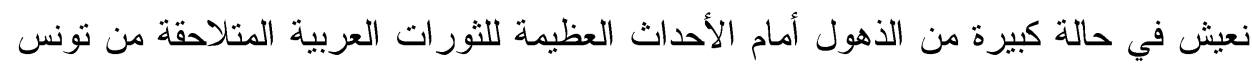

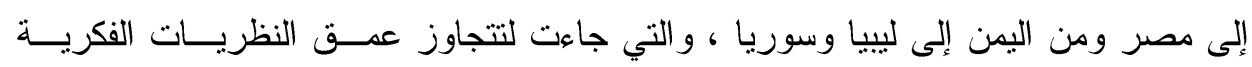

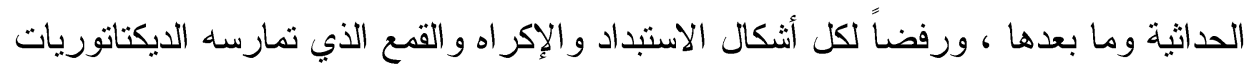

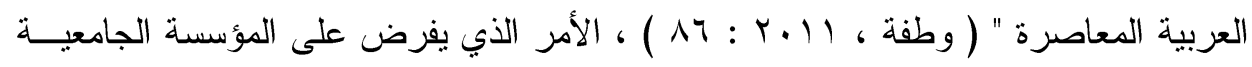

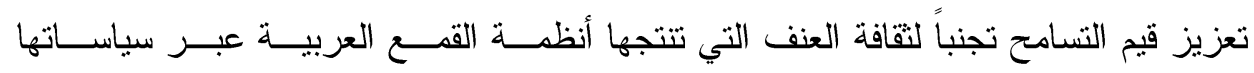
المختلفة .

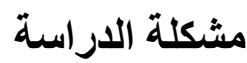

يشهـ العالم الإنساني منذ النصف الثاني من القــرن العشــرين جملـــة مــن التغيــرات

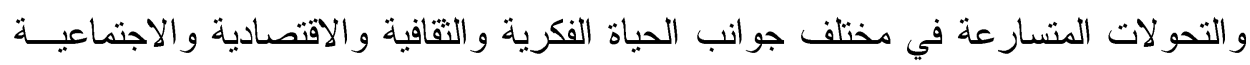

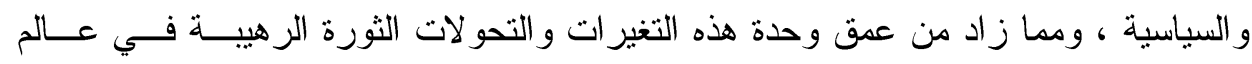

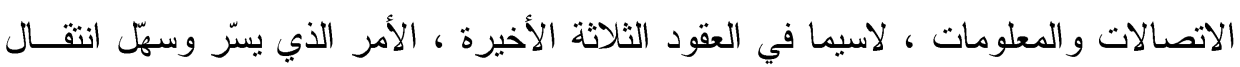

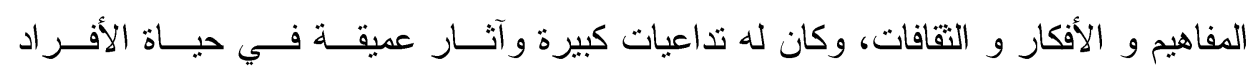

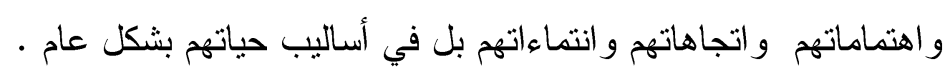

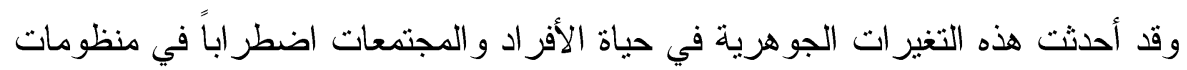

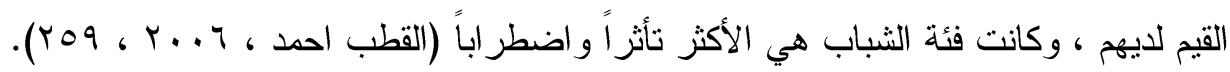

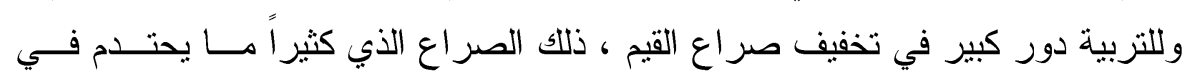

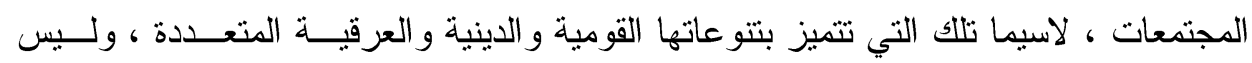

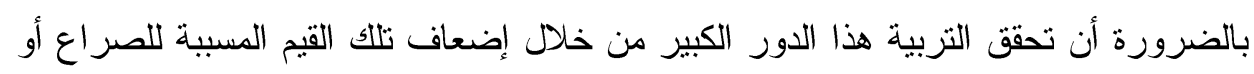

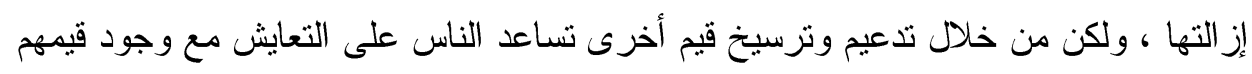


بعض قيم التسامح فى الفكر التربوى الاسلامى وكيفية تعزيزها داخل الجامعات المصرية لمواجهة العنف المجتمعى إلمال د/ آمال محمد ابر اهيم المهن

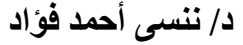

المختلفة ، ومن أهم هذه القيم التسامح الذي يعتبر بلا شك من الفضائل العظمى ويحتل مكانة

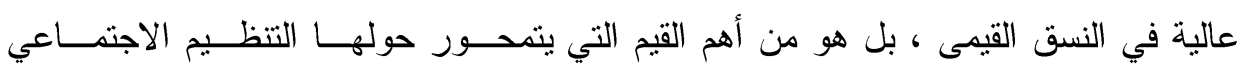

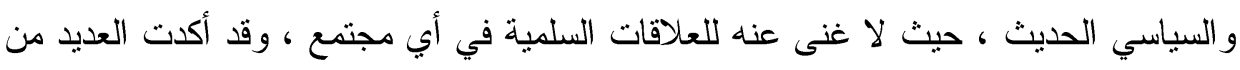

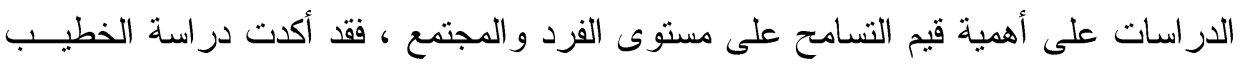

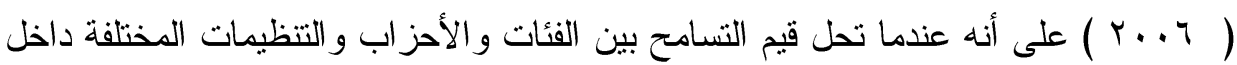

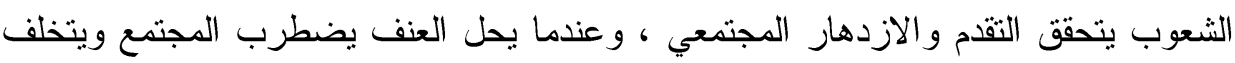

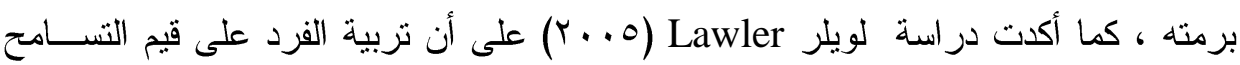

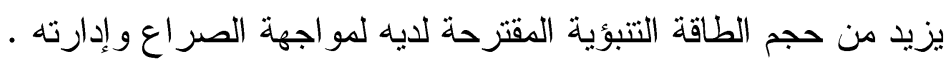

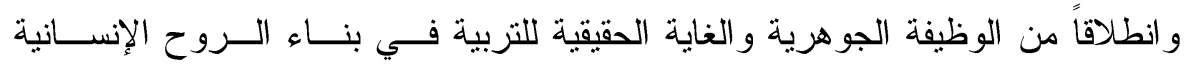

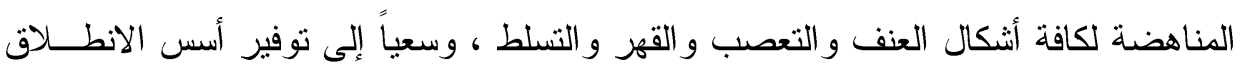

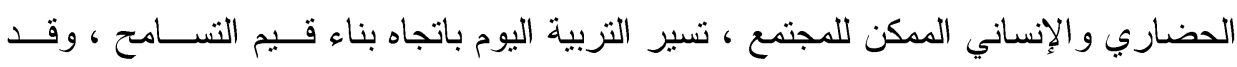

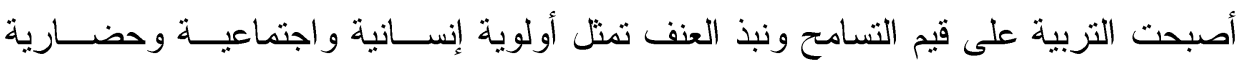

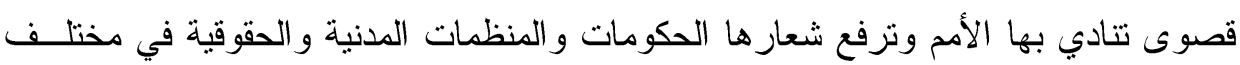

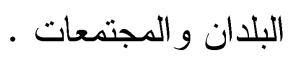

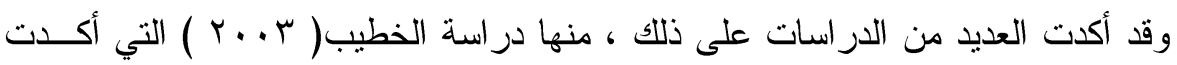

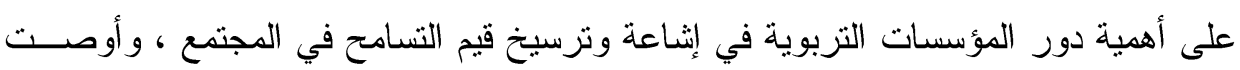
الدراسة المؤسسات التزبوية خاصة النظامية بضرورة تجاوز منهجية التعلم المجرد و التلقــين

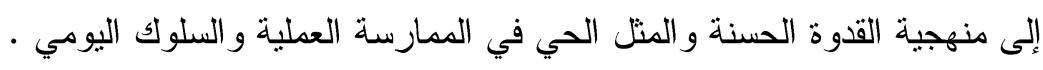

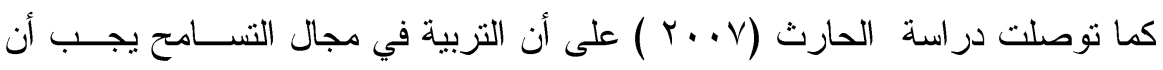
تستهدف مقاومة تأثثر العوامل المؤدية إلى الخوف من الآخرين ، ومساعدة النشه على على لتى نتمية

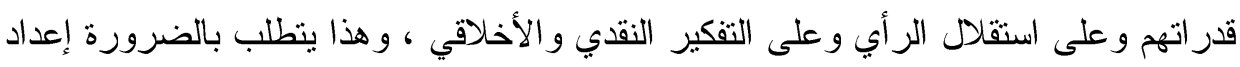

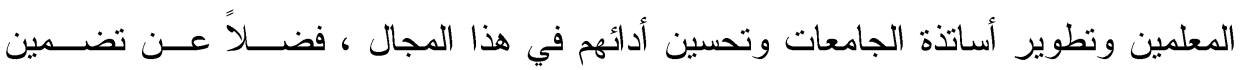

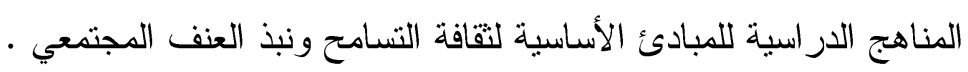

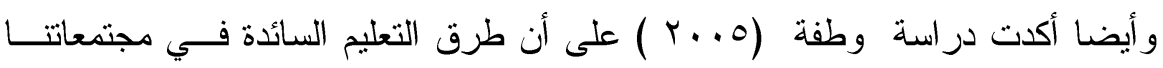

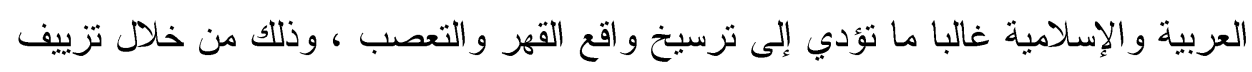

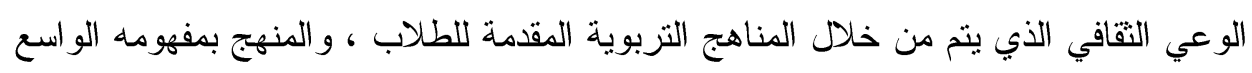
إما أن يكون أداة لبناء الإنسان الحر المتسامح أو وسيلة لتحقيق أيديولوجية الأنظمة المستبدة . 


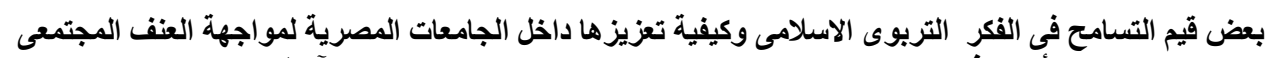
د/ آمال محمد ابر اهيم المهن

د/ تنسى أحمد فؤاد الفئر

كما نوصلت در اسة الخميسي ( ب999 (19) على وجود علاقــة جوهريسـة بـين ظــاهرة التعصب الفكري و العنف المجتمي وبين التعليم و إمكاناته الواقعية والجهد التربوي المعاصر

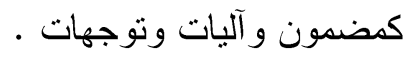

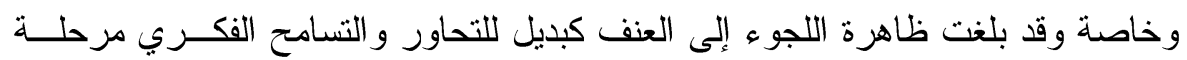

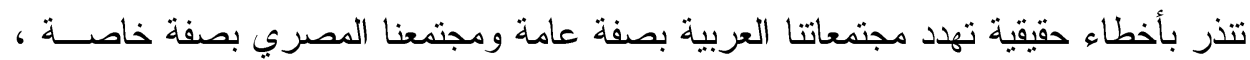

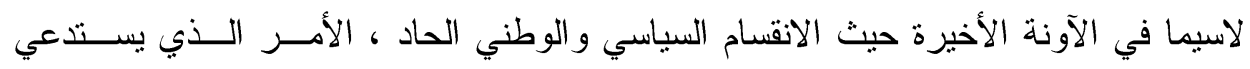

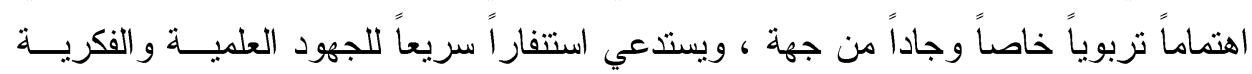
و التربوية من جهة ثانية ، وذلك لأن أداة ووقود العنف تكون في الغالب من مخرجات النظام

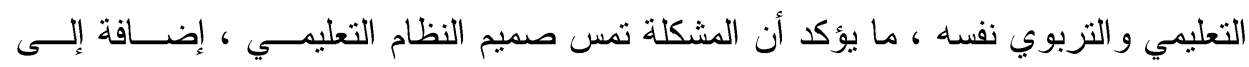

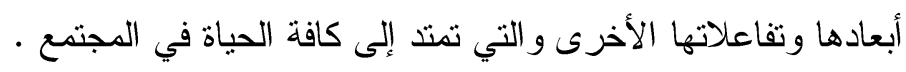

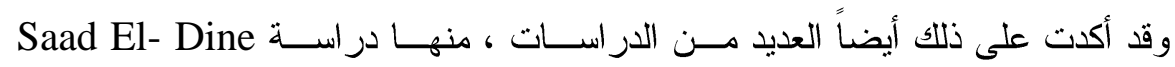

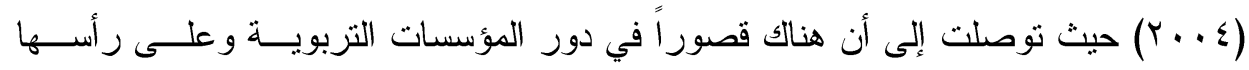

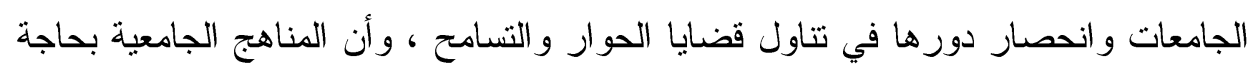

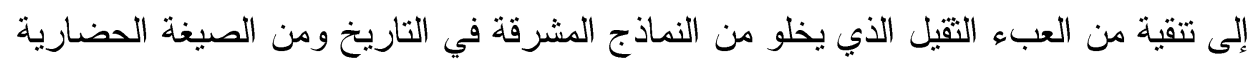
القائمة على العدالة وحقوق الإنسان .

ولكي تحقق التربية غايتها في غرس قيم التسامح في مجتمعاتتـــا العربيــة و الإســلامية

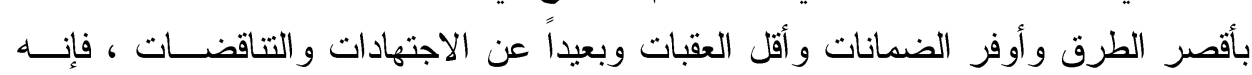

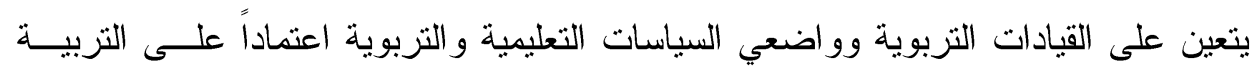

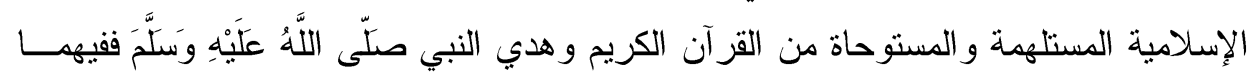

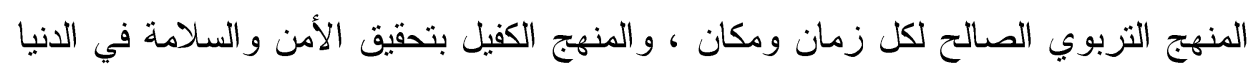
و والآخرة.

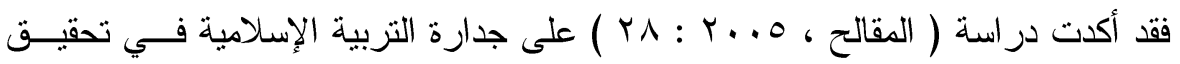

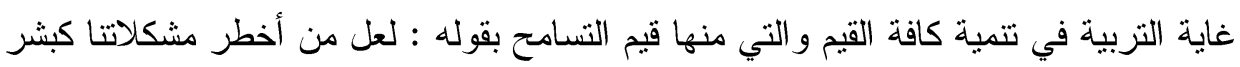

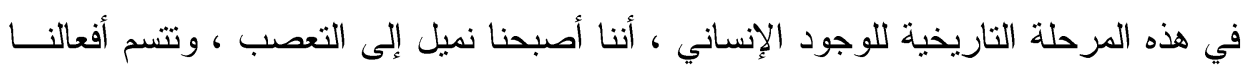

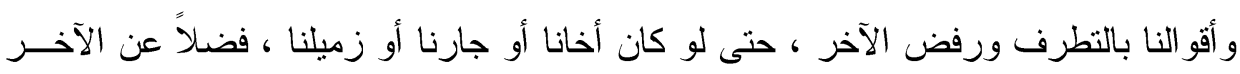

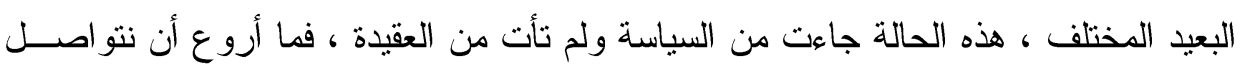

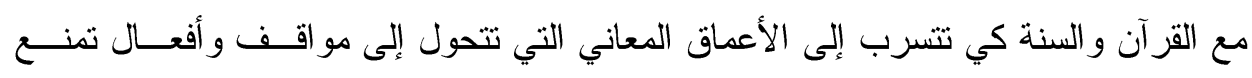

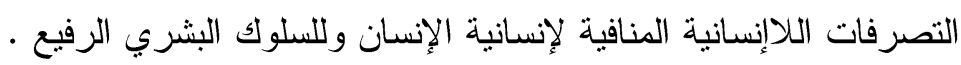


بعض قيم التسامح في الفكر التربوى الاسلامى وكيفية تعزيزها داخل الجامعات المصرية لمواجهة العنف المجتمعى

كما أكدت دراسة رمضان (ع . . r ) على ضرورة الكثف عن القيم الخلقية و التربوية المتضمنة في القرآن الكريم بصفة عامة وفي القصص القرآي بصفة خاصـــة ، وتوضــيح دورها في تربية النشء المسلم ، لأن القرآن الكريم والسنة النبوية المطهرة تزخران بمختلف وفي أنو اع القيم الخلقية و التربوية التي تعد نموذجاً لأية قضية تتطلق منها ، و التي يمكن توظيفهــا

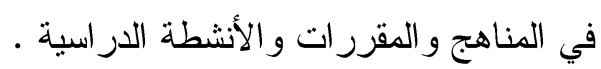
يتضح مما سبق ضرورة الحاجة إلى در اسة تحليلية لقيم التسامح في ضوء الفكر التربوي

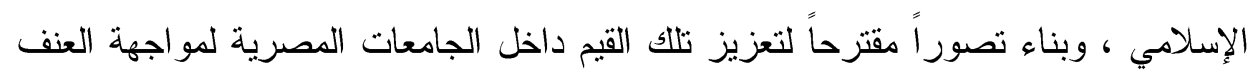
- المجتمعي

ومن هنا تبرز مشكلة الدراسة الحالية في الإجابة عن الأسئلة التالية :

ا- ما الأسس النظرية للتسامح في الأدبيات التربوية المعاصرة ؟ ץ- ما أهم القيم المتضمنة للتشامح في ضوء الفكر التزبوي الإسلامي ؟ ب- ما الأسس النظرية للعنف المجتمعي في الأدبيات التربوية المعاصرة ؟

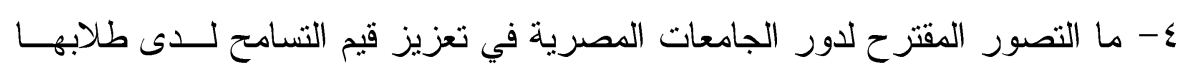

$$
\begin{aligned}
& \text { لمو اجهة العنف المجتمعي ؟ } \\
& \text { أهداف الدر اسة لهو اجة } \\
& \text { تسعى هذه الدر اسة إلى التعرف على : }
\end{aligned}
$$

ا- الأسس النظرية للتسامح في الأدبيات التربوية المعاصرة. r- أهم القيم المتضمنة للتسامح في ضوء الفكر التزبوي الإسلامي .

س- الأسس النظرية للعنف المجتمعي في الأدبيات التربوية المعاصرة.

צ- بناء تصوراً مقترحاً لدور الجامعات المصرية في تعزيز قيم التسامح لدى طلابهــا

$$
\begin{aligned}
& \text { لمو اجهة العنف المجتمعي. } \\
& \text { أهمبة الدر اسة اجة } \\
& \text { تكمن أهمية الدر اسة فيما يلي : }
\end{aligned}
$$

ا- تقديم الأسس العلمية للتصدي للمشكلات التي تواجه الثباب الجامعي ، وفي مقدمتها

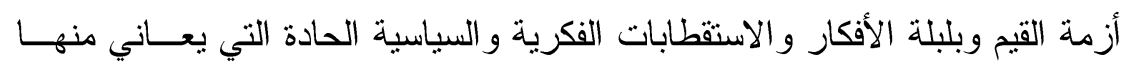

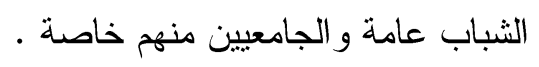
r- تسليط الضوء على دور الجامعات كواحدة من أهم المؤسسات التربوية و التعليمية في تعزيز قيم التسامح لدى طلبتها وتوجيهـم توجيها قيمياً و أخلاقياً صحيحاً . 
بعض قيم التسامح في الفكر التربوى الاسلامى وكيفية تعزيزها داخل الجامعات المصرية لمواجهة العنف المجتمعى

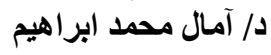

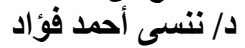

ب- توجيه أنظار القائمين على تخطيط الأنظمة التزبويــة و التعليميــة للـــشه داخــل

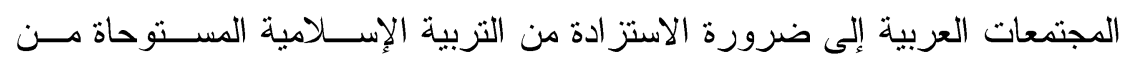

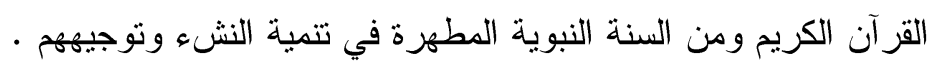

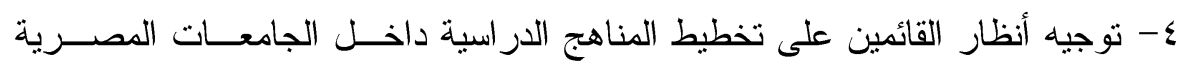

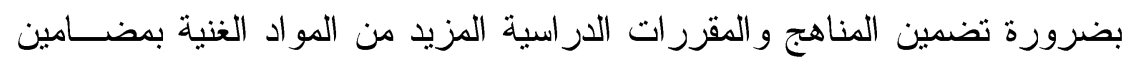

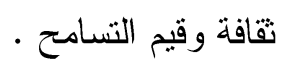

ه- إفادة وزارة التعليم العالي و الإدارات الجامعية من هذه الدراسة في وضع خططهـــا وسياساتها وبر امجها المستقبلية . ؟- إفادة الباحثين التزبويين والاجتماعيين في دراسة الظواهر التزبوية والاجتماعية ذات

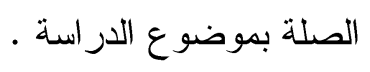

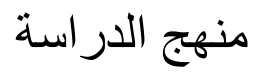

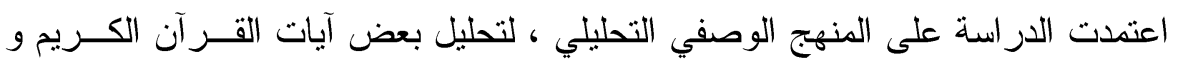

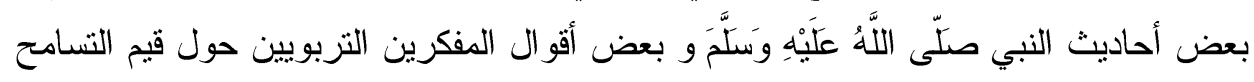

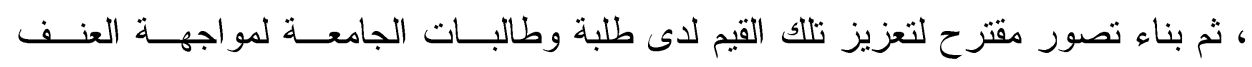

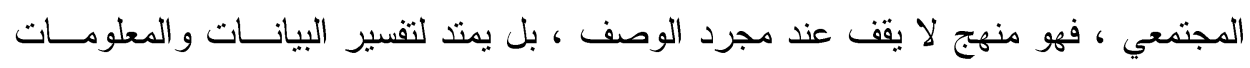

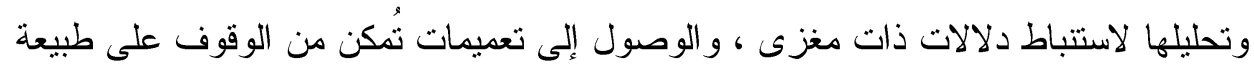

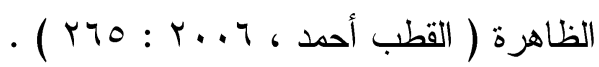

$$
\begin{aligned}
& \text { مصطلحات الدر اسة النة }
\end{aligned}
$$

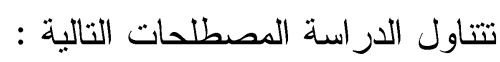

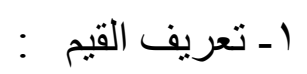

يمكن تعريف القيم لغةً ، فالقيمة : مفرد " قيم " لغة " من " قوم "و " قام المتاع بكـذا أي لئ تعدلت قيمته به ".

و القيمة : الثمن الذي يقوم به المتاع ، أي يقوم مقامه ، و الجمع : القيم ، مثل سدرة وسدر

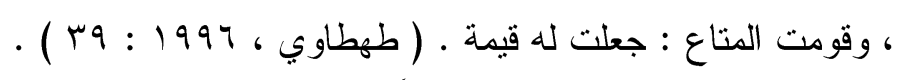

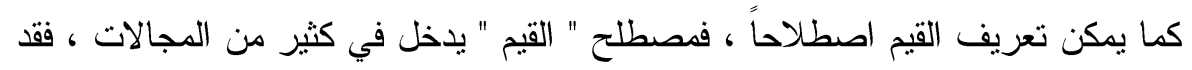

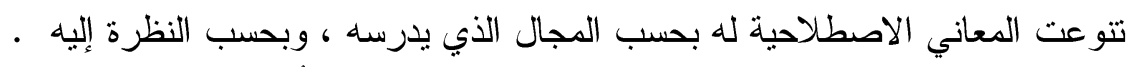

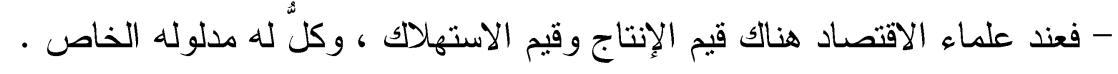


بعض قيم التسامح في الفكر التربوى الاسلامى وكيفية تعزيزها داخل الجامعات المصرية لمواجهة العنف المجتمعى

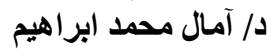

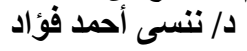

- و عند علماء الاجتماع : القيمة هي الاعتقاد بأن شيئًا ما ذا قدرة على إنثباع رغبة إنسانية،

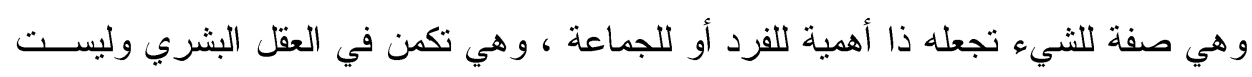

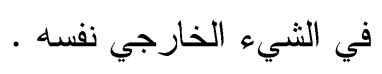

- و وعند الفلاسفة تعد القيم جزءاً من الأخلاق و الفلسفة السياسية .

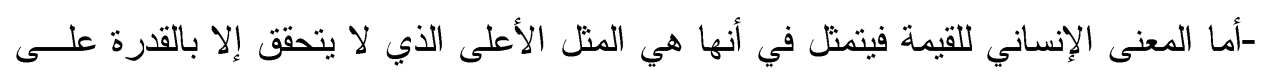
العمل و العطاء . العبن الان.

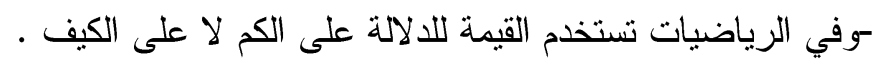

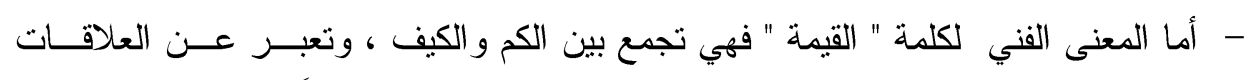

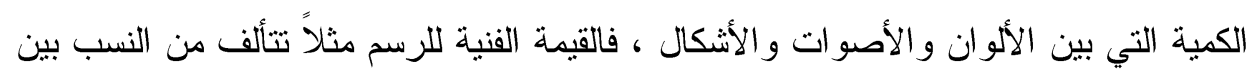

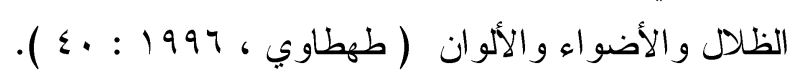

كو أما القيمة اللغوية ( وهي غير المعنى اللغوي للقيمة ) فهي قيمة اللغة ، وهي لا لانتأتَّى إلا في

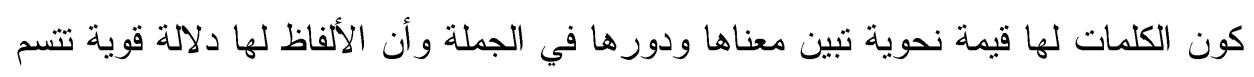

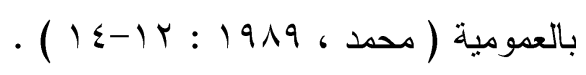

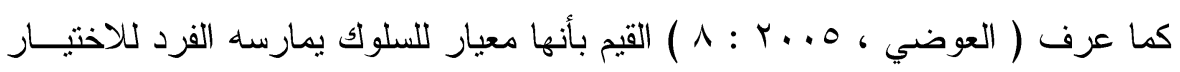

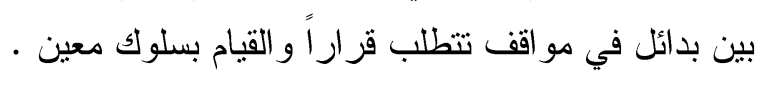
ويمكن تعريف القيم إجر ائيا كالتالي : بأبن

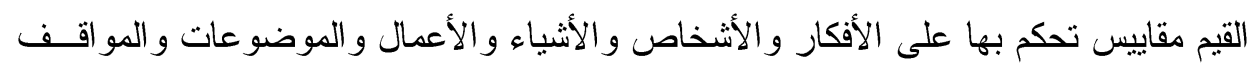

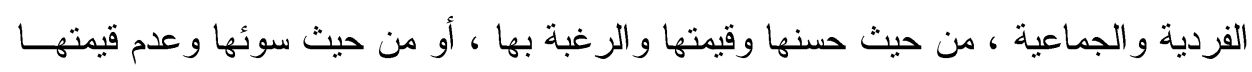

$$
\text { تعريف التسامح لغة : }
$$

يمكن تعريف التسامح لغةً ، فأصل كلمة التسامح في اللغة العربيــة يعــود إلــى مــادة

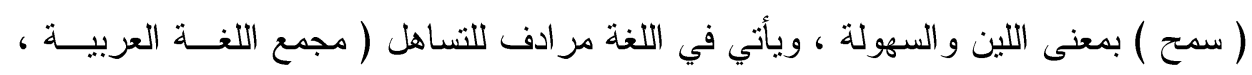
. ( $\leqslant \leqslant V: 1991$

وتحمل مر ادفة ( التسامح ) اختلافاً في المعنى بين اللغتين العربية و الانجليزية ، ويرجع

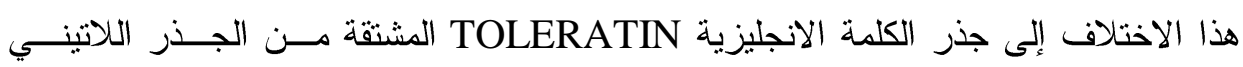
tolerare

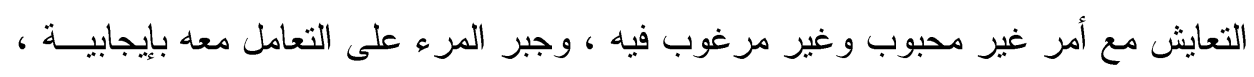

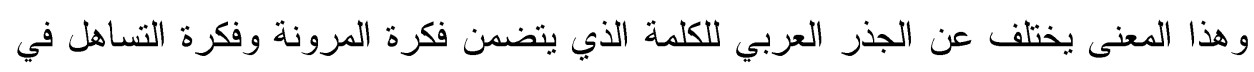


بعض قيم التسامح في الفكر التربوى الاسلامى وكيفية تعزيزها داخل الجامعات المصرية لمواجهة العنف المجتمعى آلمال د/ آمال محمد ابر اهيم المهن

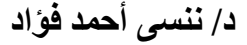

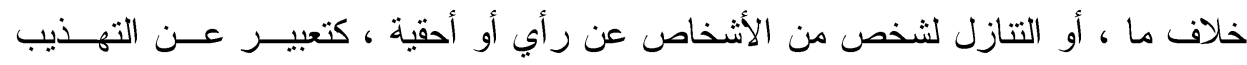

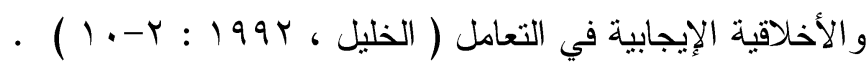

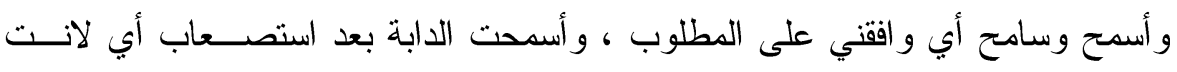

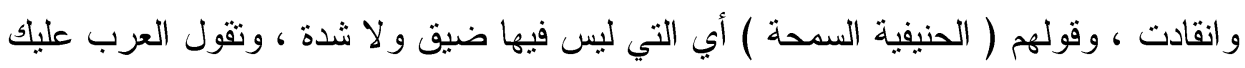

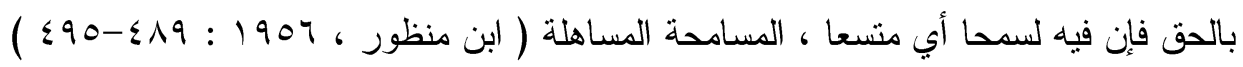

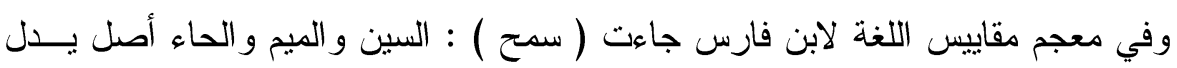
على سلاسة وسهولة ( ابن فارس ، $19 \vee 9$ 1 : 99 ) .

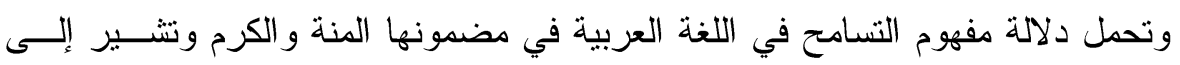

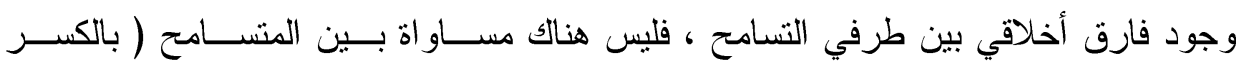

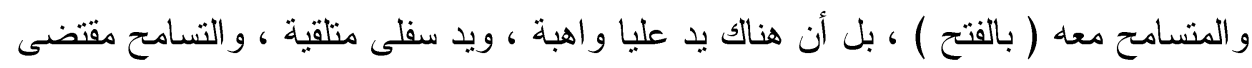

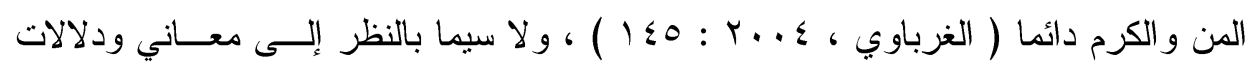

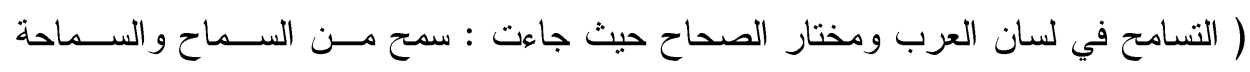

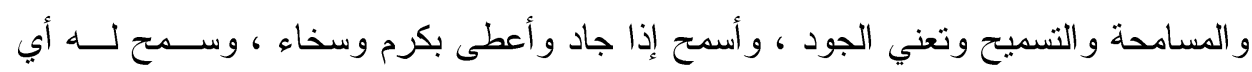

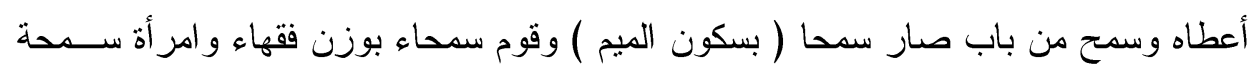

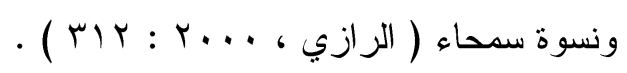

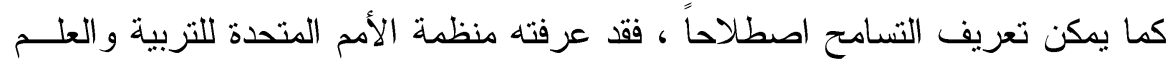

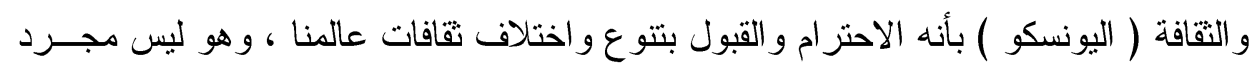
واجب أخلاقي ، ولكنه أيضا ضرورة سياسية وقانونية وهو فضيلة تجعل السلام ممكناً عالمياً

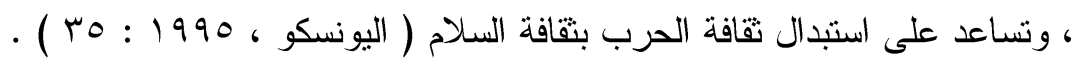

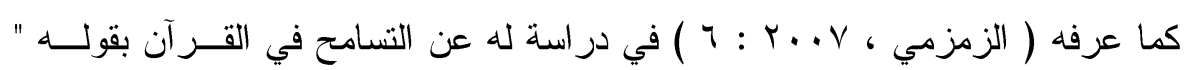

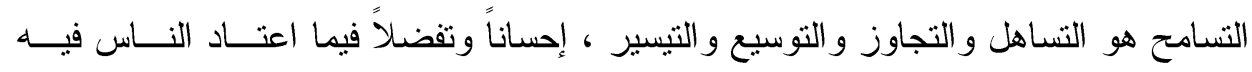

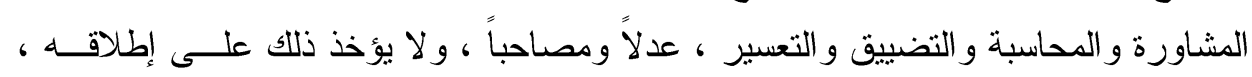
و إنما هو تسامح بضو ابط " .

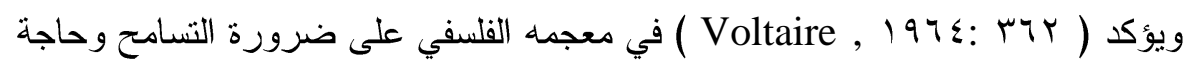
الإنسانية إلى تعميمها بقوله : إن استقصاء الطيعة الإنسانية ، و اكتثاف ما تحتويه من إمكانية

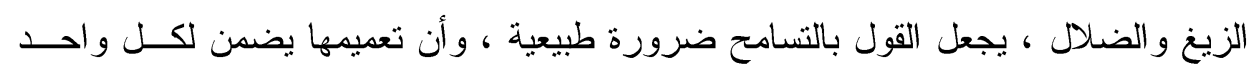

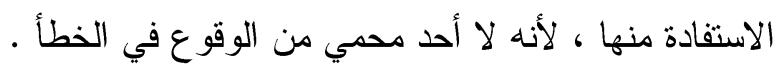

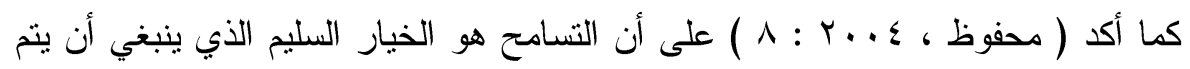

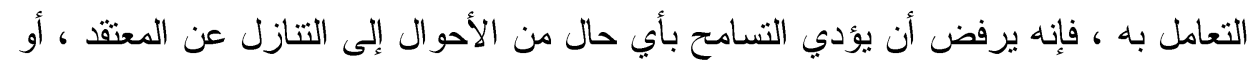


بعض قيم التسامح في الفكر التربوى الاسلامى وكيفية تعزيزها داخل الجامعات المصرية لمواجهة العنف المجتمعى

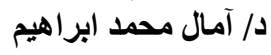

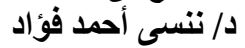

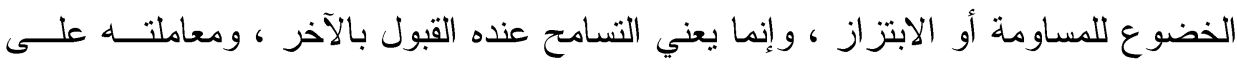

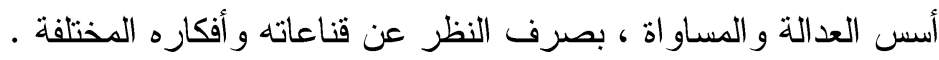

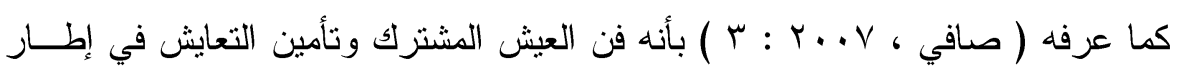

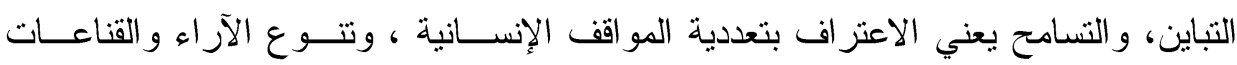

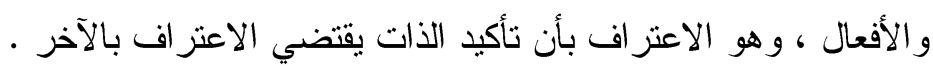

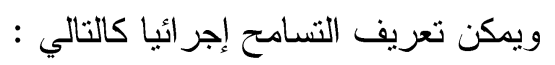

التسامح سلوك معبر عن امتثال الفرد لمنظومة من القـيم الإنســانية و الأخلاقيــة و الدينيــة

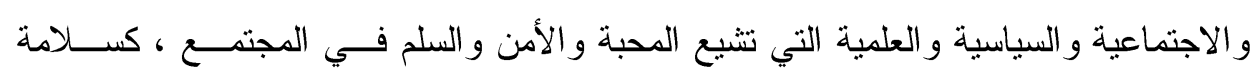
الصدر و الصفح و الإخاء وقبول الآخر . r- تعريف العنف

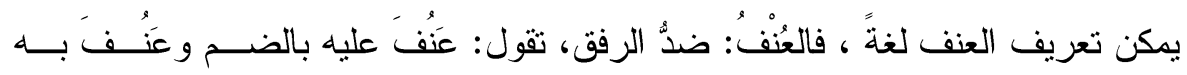

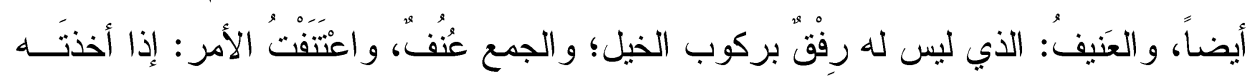

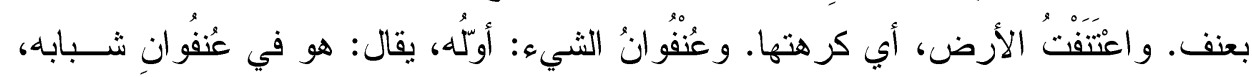

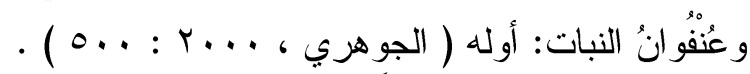

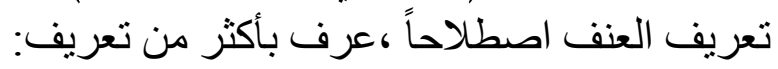

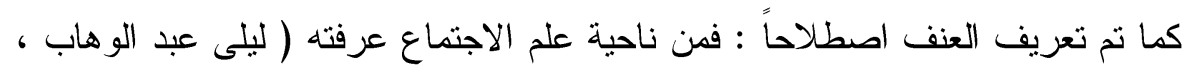

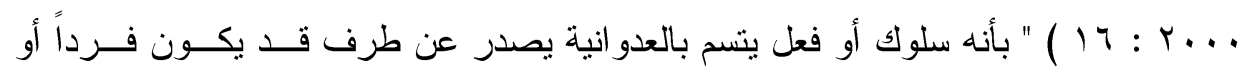

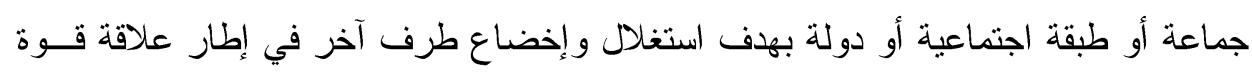

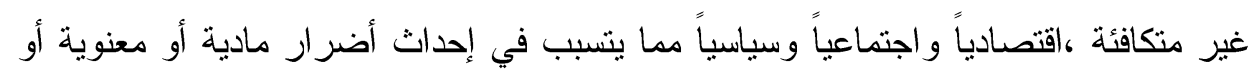
نفسية لفرد أو جماعة أو طبقة اجتماعية أو دولة أخرى" .

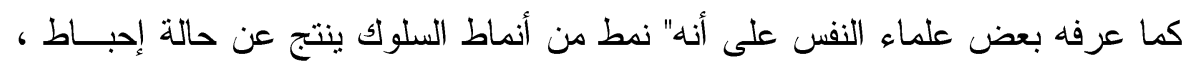

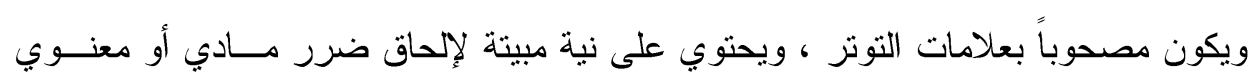

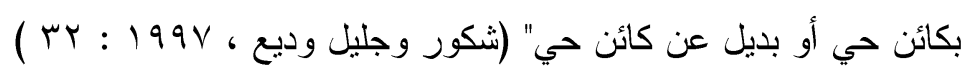
وعرفه أيضاً ( أبو زنيد ومحمد سالم ، ... . . : ع 1 ) بأنه استعمال القوة في غير محلها

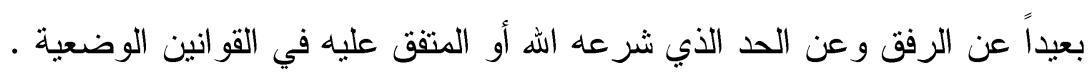

الدر اسات السابقة

تتتاول الدراسة الحالية العديد من الدراسات السابقة التي يمكن تحديدها فيما يلي : 
بعض قيم التسامح في الفكر التربوى الاسلامى وكيفية تعزيزها داخل الجامعات المصرية لمواجهة العنف المجتمعى آمال د/ آمال محمد ابر اهيم المنف المجنم د/ نتسى أحمد فؤاد الفري

$$
\text { أولاً : الدر اسات العربية }
$$

فيما يلي مجموعة من الدراسات العربية ذات الصلة بموضوع الدار الدة الحالية ، ومرتبة

$$
\begin{aligned}
& \text { وفق حداثتها من الأحدث إلى الأقدم . }
\end{aligned}
$$

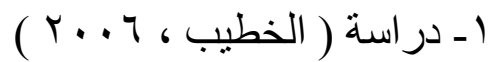

هدفت هذه الدراسة إلى التعرف على و اقع التسامح بين التنظيمات و الأحزاب السياسية ،

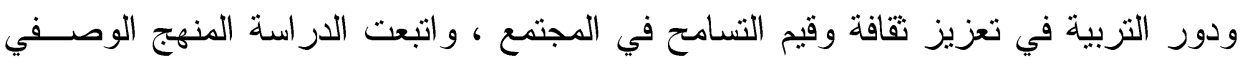
التحليلي ، وقد توصلت الدراسة إلى النتائج التالية :

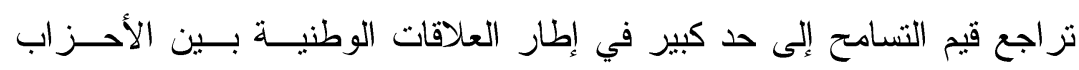
السياسية.

أنه عندما يحل التسامح بين فئات الأحزاب السياسية يتحقق التقدم والازدهــار ،

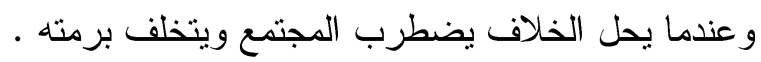

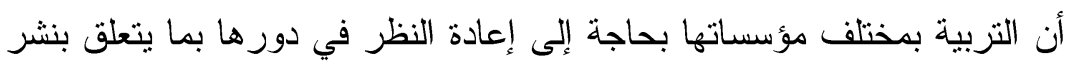

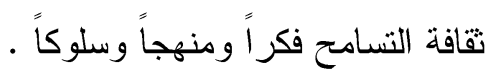

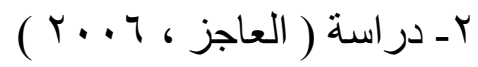

هدفت هذه الدراسة إلى التعرف على أهم القيم التي تتميها الجامعة الإسلامية لدى طلبتها

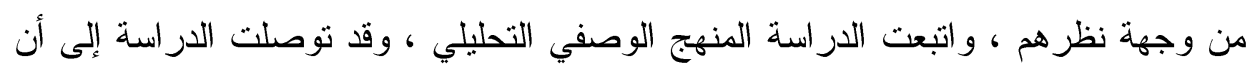

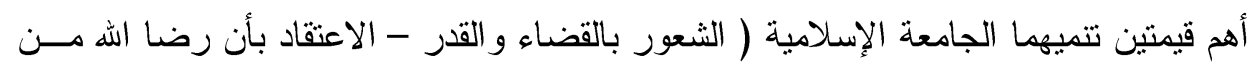

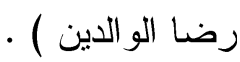

$$
\begin{aligned}
& \text { r- در اسة ( القطب أحمد ، } 7 \text {. . . T ) }
\end{aligned}
$$

هدفت هذه الدراسة إلى الوقوف على دور الجامعة و آلياتها في تعميق قيم الانتـــاء

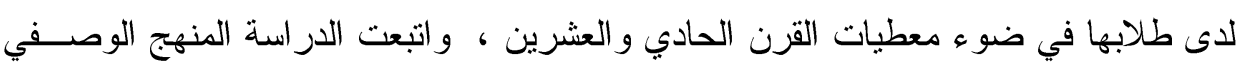

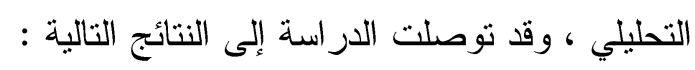

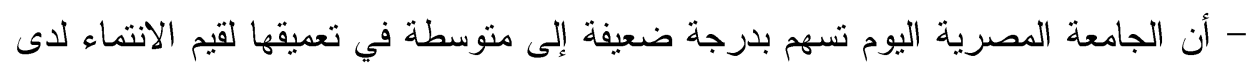

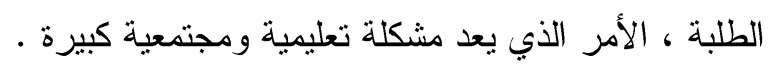

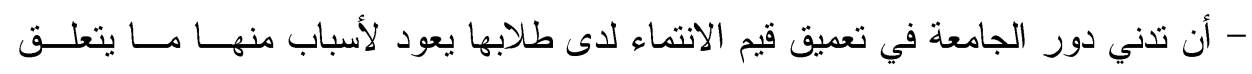
بالجامعة وقدرتها الذاتية على النهوض و المواكبة ، وطبيعة المقررات الدراسية ، و والإمكانات

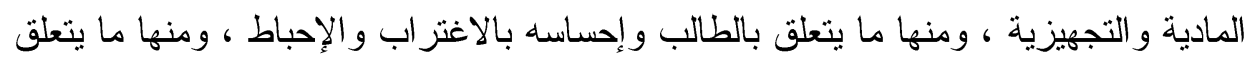

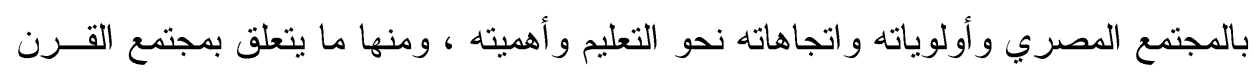


بعض قيم التسامح في الفكر التربوى الاسلامى وكيفية تعزيزها داخل الجامعات المصرية لمواجهة العنف المجتمعى

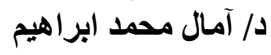

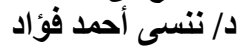

الحادي و العشرين ومعطياته وما تفرضه هذه المعطيات من تحديات أمام المجتمع ومؤسســاته

$$
\begin{aligned}
& \text { المختلفة . } \\
& \text { عـ در اسة ( التلولي ، } 0 \text {. . ب ) }
\end{aligned}
$$

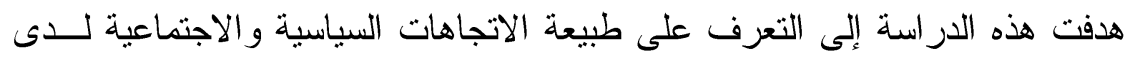

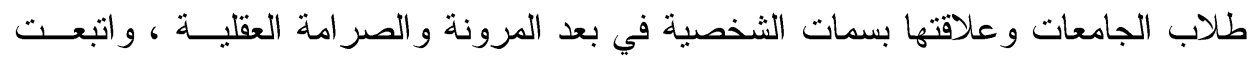

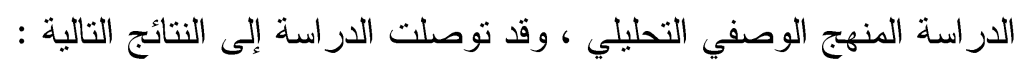
- وجود علاقة سالبة بين العدو انية وكل من التدين و التسامح و المسالمة .

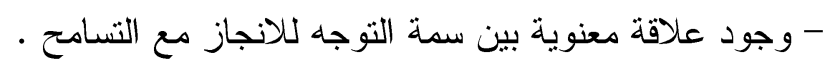

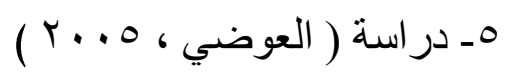

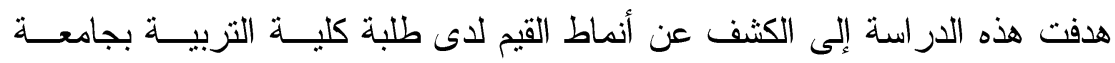

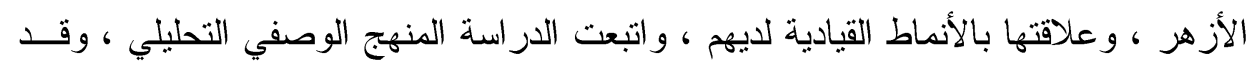
توصلت الدراسة إلى النتائج التالية: - أن ترتيب القيم عند الطلاب كان على النحو التالي : القيم الدينية ثم القيم السياسية ثم القـيم

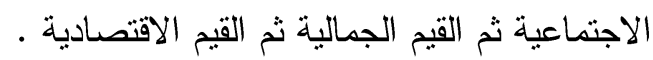

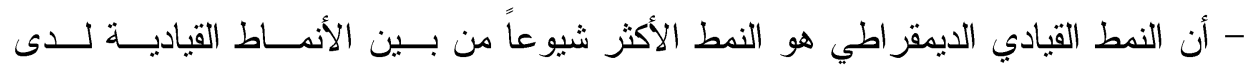
الطلاب . - وجود ارتباط موجب بين كل من القيم الدينية و الاجتماعية و النمط القيادي .

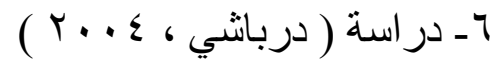

هدفت هذه الدراسة إلى التعرف على دور الجامعات في تتمية النسق القيمي لاى طلابها

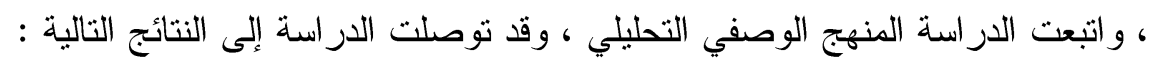
- أن القيم الدينية تأتي عادة في قمة الهرم القيمي لدى طلاب الجامعات تليها القيم الاجتماعية

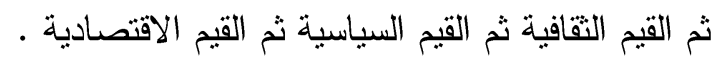

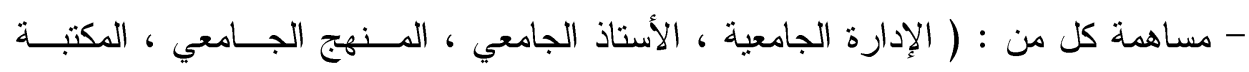

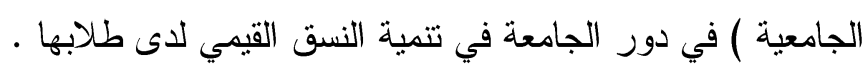

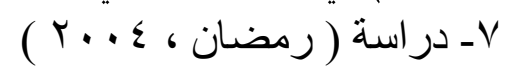

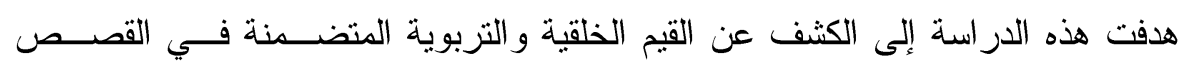

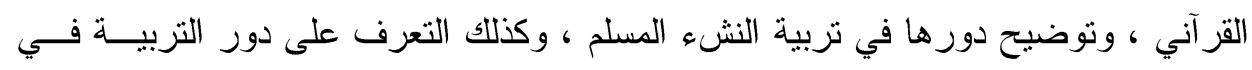


بعض قيم التسامح في الفكر التربوى الاسلامى وكيفية تعزيزها داخل الجامعات المصرية لمواجهة العنف المجتمعى

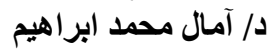

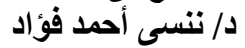

توظيف تلك القيم و الاستفادة منها ، و اتبعت الدراسة المنهج الوصفي التحليلي ، وقد توصـلت

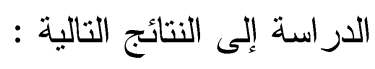
- أن القصص القرآني يزخر بالمئات من القيم الخلقية و التربوية و التي يمكن توظيفها و العمل

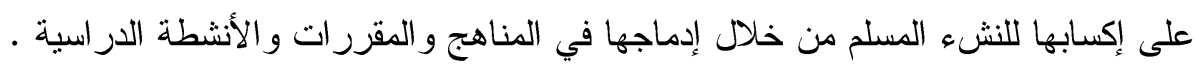

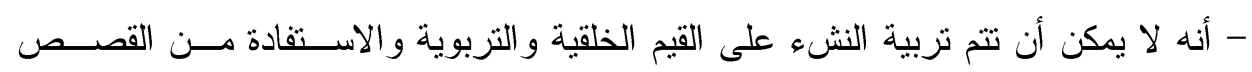

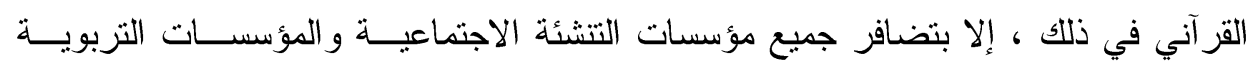

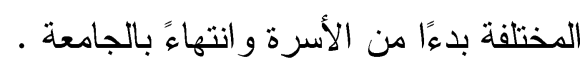
- أن الصدق والصبر و الرحمة و التسامح و العدل و العلم والعمل من أهم القيم الخلقية التربوية

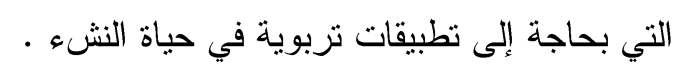

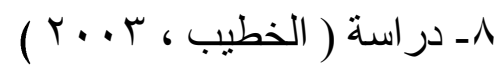

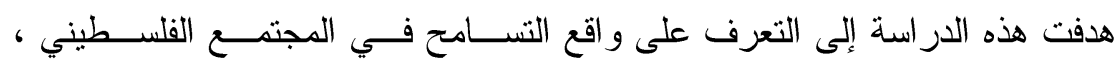

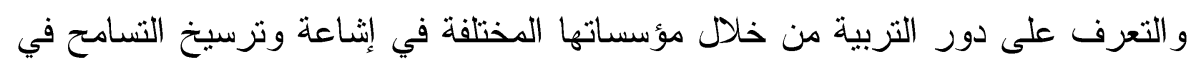

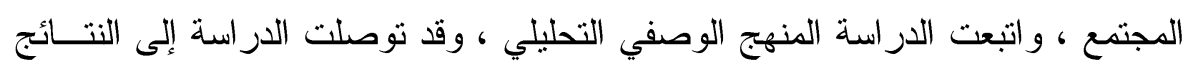
التالية : التجئم ،

- أن التربية من خلال مختلف مؤسساتها التربوية لاسيما النظامية منها ، بحاجة إلى تجـاوز

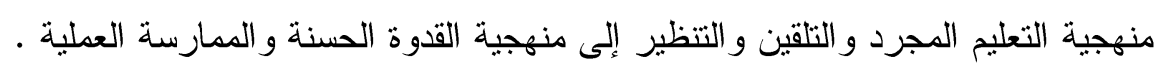

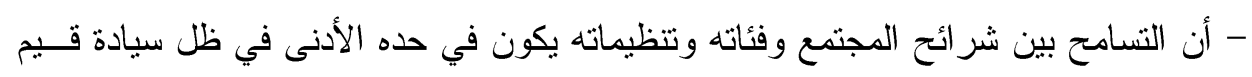

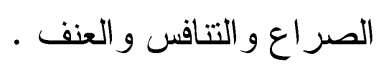

$$
\begin{aligned}
& \text { 9- در اسة ( المزيني ، ( . . ب ) }
\end{aligned}
$$

هدفت هذه الدراسة إلى الكثف عن مدى تمسكك قيم الجامعة الإسلامية بغزة بالقيم الدينية

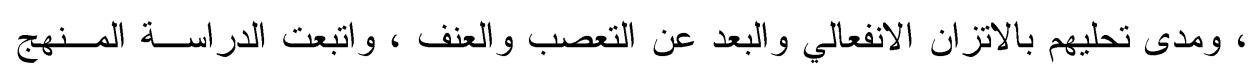

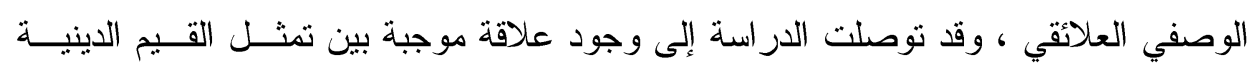

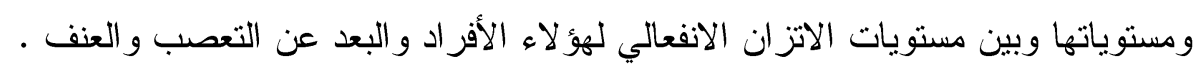

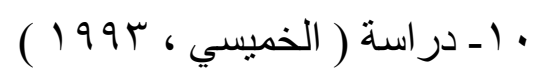
هدفت هذه الدراسة إلى الكشف عن بعض أوجه العلاقات بين ظاهرة التعصب الفكري

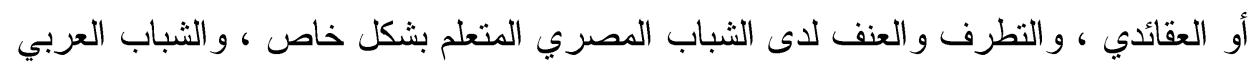

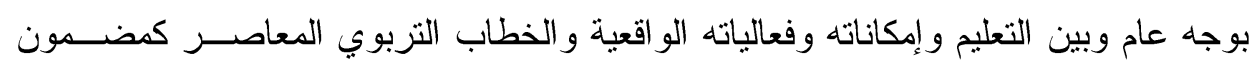

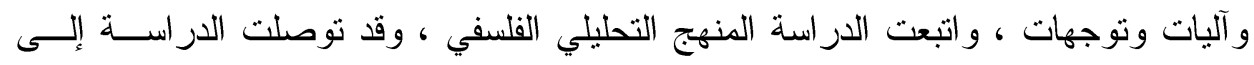
النتائج التالية : وتوجيات 
بعض قيم التسامح في الفكر التربوى الاسلامى وكيفية تعزيزها داخل الجامعات المصرية لمواجهة العنف المجتمعى آمال د/ آمال محمد ابر اهيم المنف المجنم

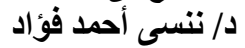

- أن مشكلة العنف و التعصب و التطرف هي في أصل نشوئها وتتاميها مشكلة تربوية ، لأنها تتعلق أساساً بغياب نقافتي التسامح و الحرية في مختلف مناحي الحياة .

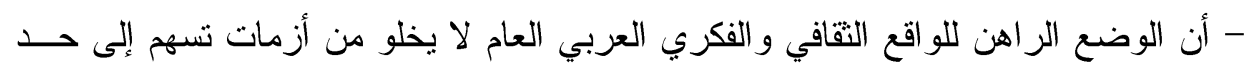

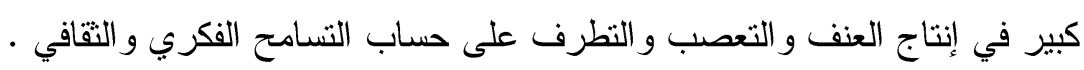
1)

هدفت هذه الدراسة إلى التعرف على دور كليات التزبية بجامعة أسيوط في تدعيم السلوك

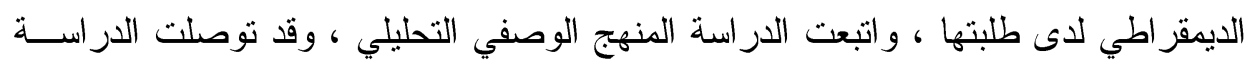

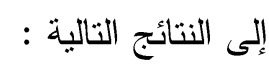
- أنه لم يكن للكلية دور و اضح في تدعيم القيم الديمقر اطية .

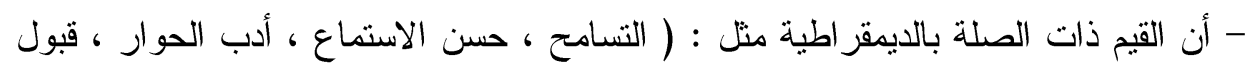

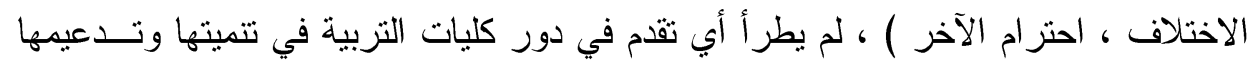

$$
\begin{aligned}
& \text { في سلوك الطلاب . } \\
& \text { ثانيا : الدر اسات الأجنبية }
\end{aligned}
$$

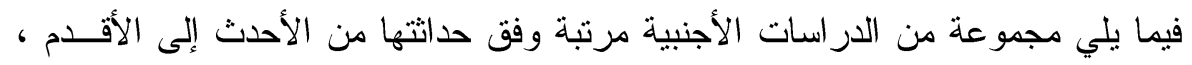

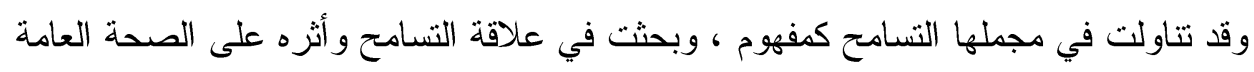

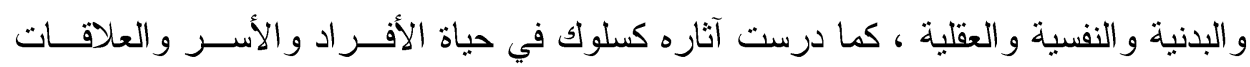

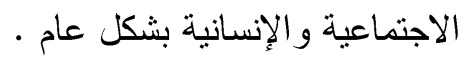

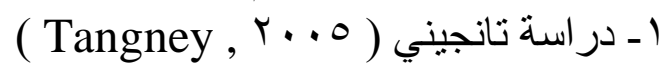

هدفت هذه الدر اسة إلى التعرف على النتائج النفسية و الاجتماعية لمسامحة الذات و العلاقة

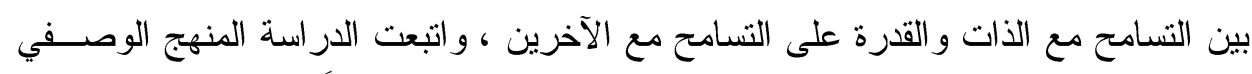

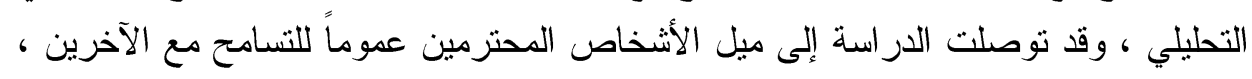

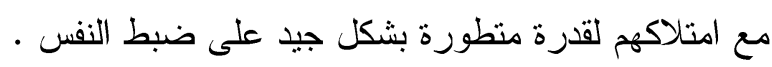

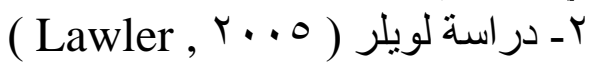

هدفت هذه الدراسة إلى التعرف على أثز التسامح و الصفح على الصحة البدنية و المعنوية

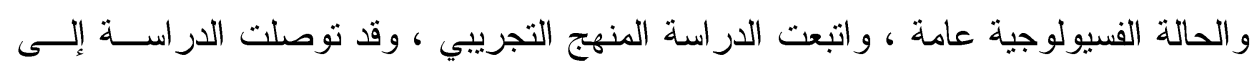
النتائج التالية : والفة - أن الصفح و النسامح يزيد من حجم الطاقة التتبؤية المقترحة لمواجهة الصــر اع و العنـــ و إدارته.

- أن هناك علاقة ارتباطيه دالة موجبة بين التسامح و الصفح وبين استقرار الحالة الصحية . 
بعض قيم التسامح في الفكر التربوى الاسلامى وكيفية تعزيزها داخل الجامعات المصرية لمواجهة العنف المجتمعى

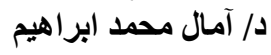

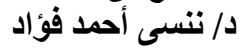

- أن هناك علاقة ارتباطيه دالة موجبة بين التسامح و الصفح وبين مؤشرات الكفاءة الثخصية

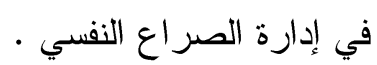

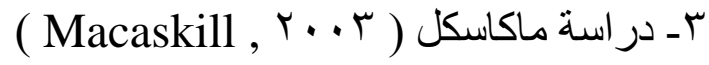

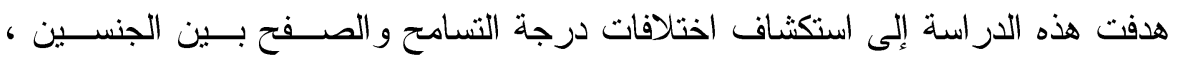

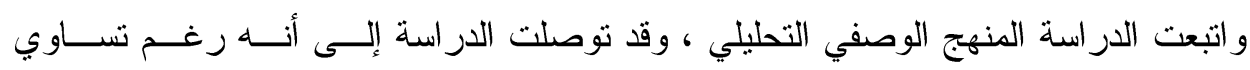

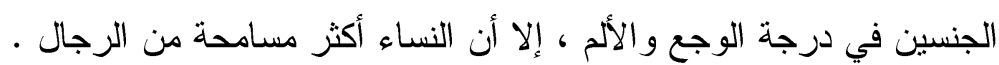

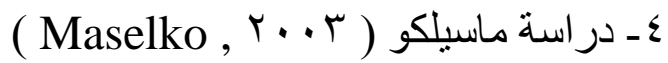

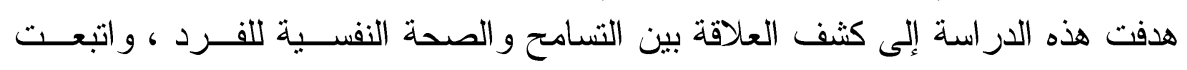

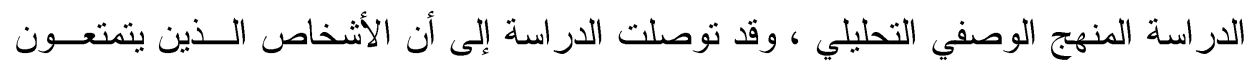

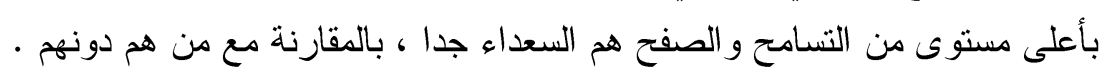

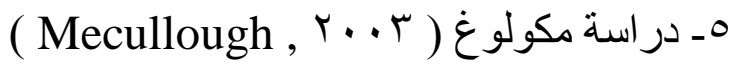

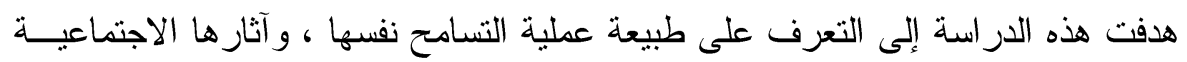

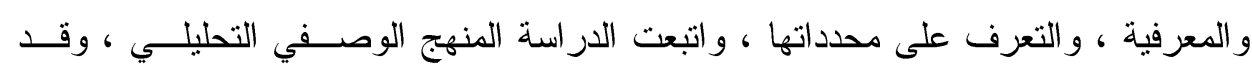
توصلت الدراسة إلى النتائج التالية :

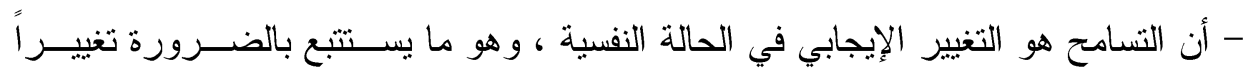

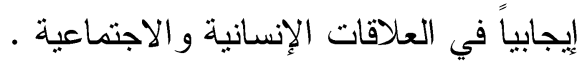

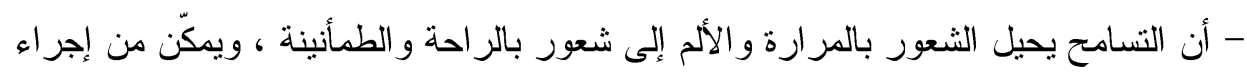

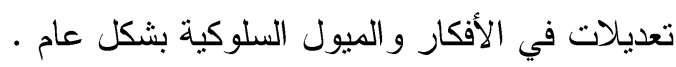

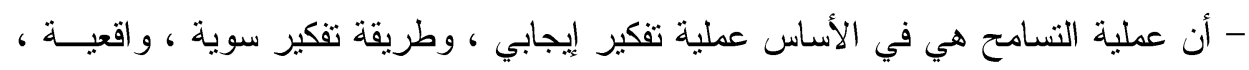

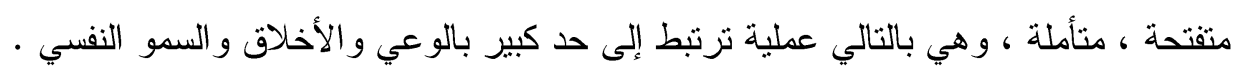

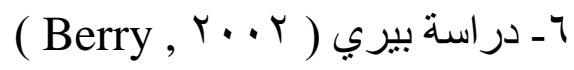

هدفت هذه الدر اسة إلى التعرف على موقع قيم التسامح بين بقية القيم الأخلاقية ، و اتبعت

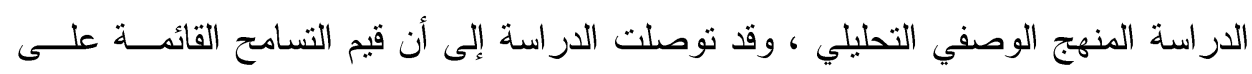

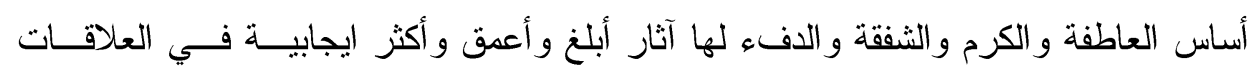
الإنسانية من التسامح القائم على الصبر وضبط النفس و العدل .

$$
\text { تعقيب على الدر اسات السابقة }
$$

يمكن الوقوف من عرض الدراسات السابقة إلى عدة نقاط : 
بعض قيم التسامح في الفكر التربوى الاسلامى وكيفية تعزيزها داخل الجامعات المصرية لمواجهة العنف المجتمعى د/ آمال محمد ابر اهيم المنف المجنم

د/ نتسى أحمد فؤاد الدي

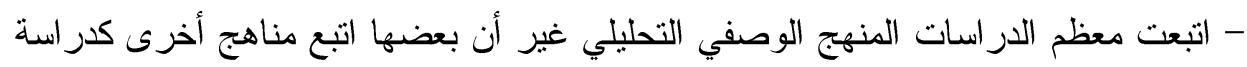

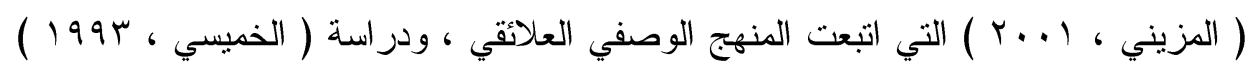

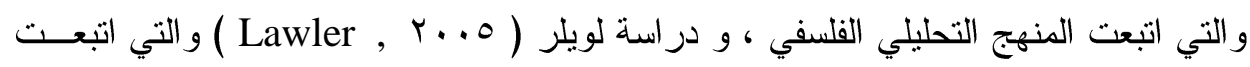
المنهج التجريبي.

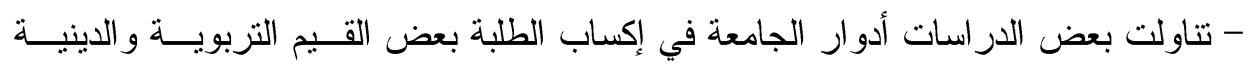

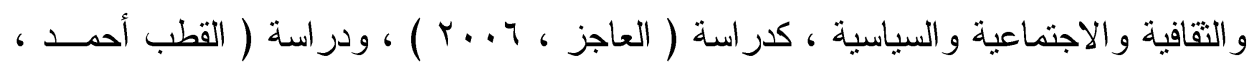

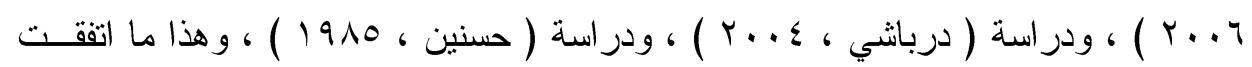

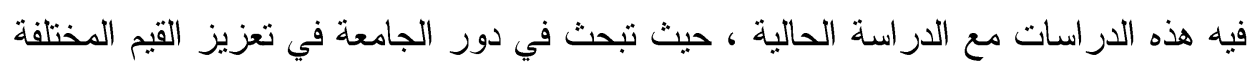

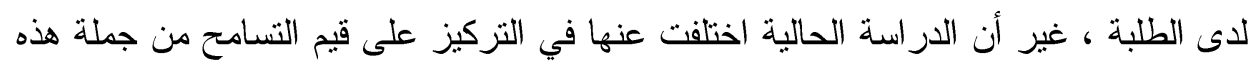
القيم

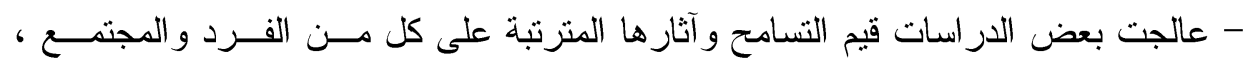

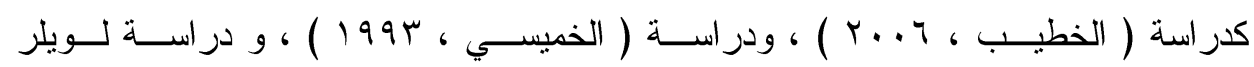

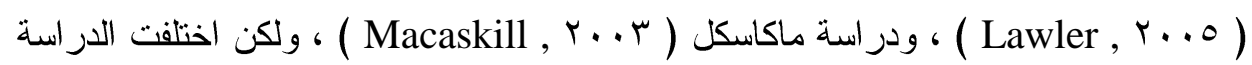

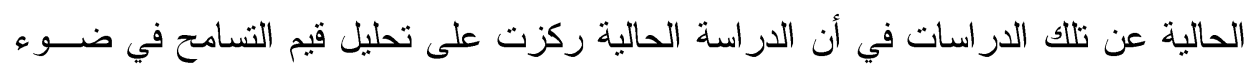

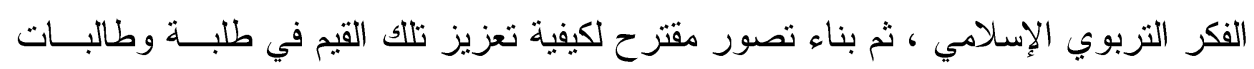
الجامعات المصرية لمو اجهة العنف المجتمعي.

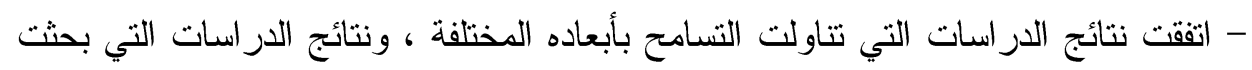

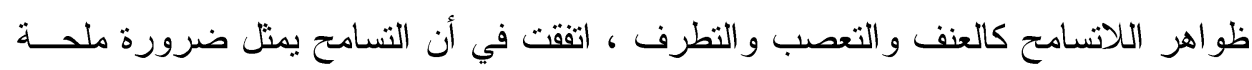

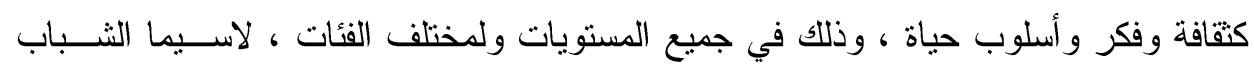

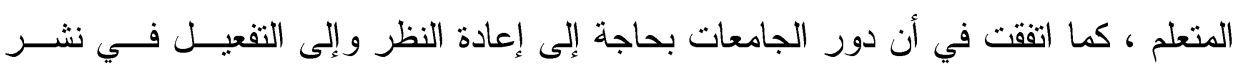

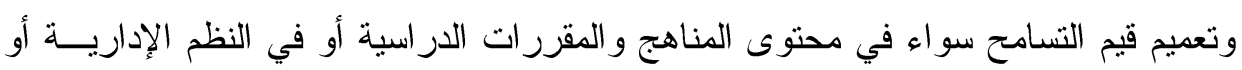

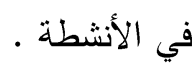

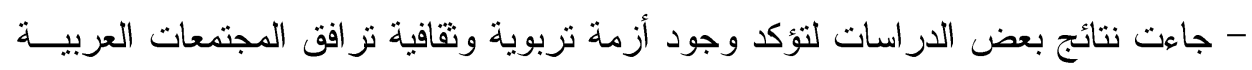

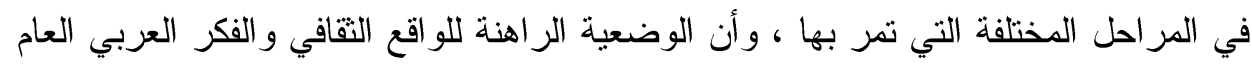

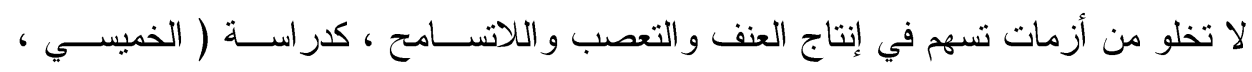

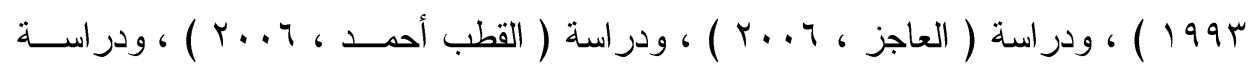

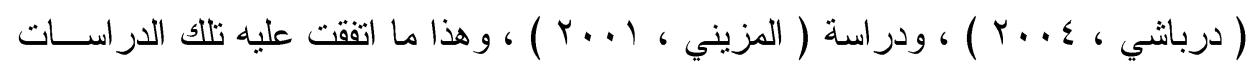

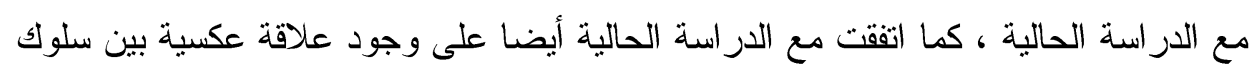


بعض قيم التسامح في الفكر التربوى الاسلامى وكيفية تعزيزها داخل الجامعات المصرية لمواجهة العنف المجتمعى

الأفر اد من عنف وتعصب وتطرف وبين الوعي الديني و الفهم الصـــحيح للــدين ومقاصـــه الكبرى وتعاليمه السمحة . ما استفادته الدر اسة الحالية من الدار اسات السابقة - توفير المجال الخصب للاطلاع وبلورة مشكلة الدراسة وتحديدها وعمل الخطة وإجراءات التهات الدراسة .

- توفير العديد من المصادر و المر اجع العلمية اللازمة و المفيدة للدر اسة الحالية .

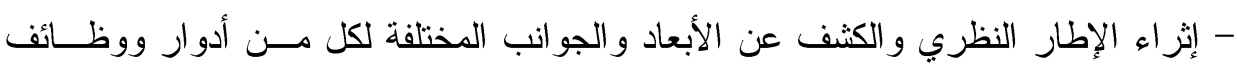

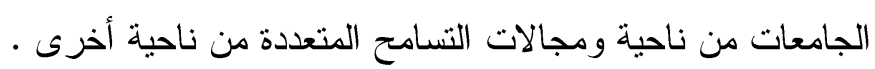

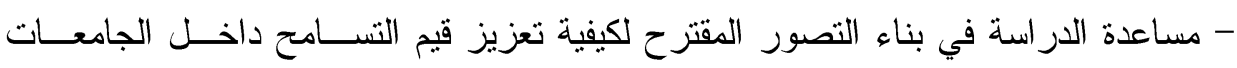
المصرية، من خلال المناهج الدراسية ، الإدارة الجامعية ، أعضاء هيئة التدريس ، و الأنشطة النداء

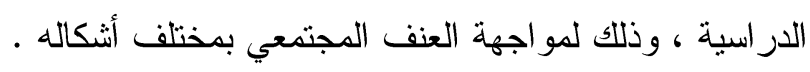

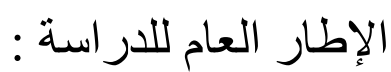

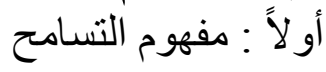

قد تم تعريف النسامح لغوياً واصطلاحياً مسبقًا في مصطلحات الدراسة ، وفي ضوء ما

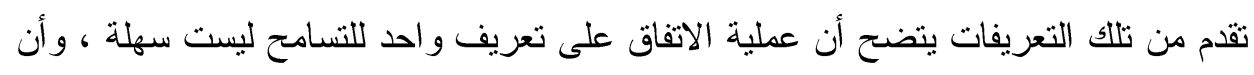

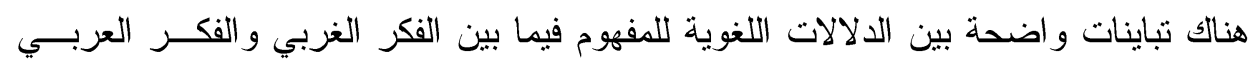

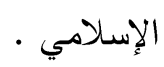

ويمكن من التعريفات السابقة لمفهوم التسامح ، ومن تحليل مختلف الفلاسـفة و العلىــاء

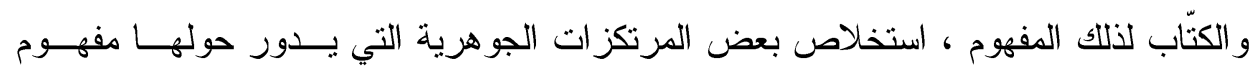

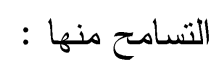

1- أن التسامح قد عرفته الحضارات الإنسانية ، كما عرفت ما يقابله من مفاهيم العنف

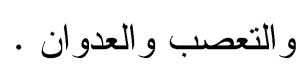

r- أن مفهوم التسامح شغل مساحات كبيرة في الآداب الفكرية لمختلف الأديان السماوية ، وكذلك مختلف الفلسفات الإنسانية القديمة .

ب- اختلاف الدلالة اللغوية للفظة التسامح فيما بين اللغة العربية و اللغات الأجنبية .

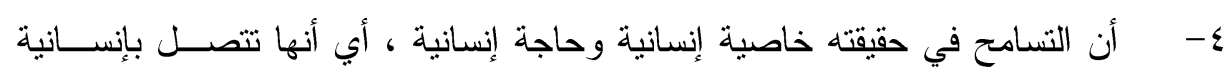
الإنسان التي كرمها الله و التي ينبغي أن تُحترم وتُصان . 
بعض قيم التسامح في الفكر التربوى الاسلامى وكيفية تعزيزها داخل الجامعات المصرية لمواجهة العنف المجتمعى د/ آمال محمد ابر اهيم المنف المجنم

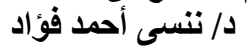

ه- أن التسامح لا يُلغي الاختلاف و لا ينفي التعارض ، ولكنه يساعد على إحالـــة هـــا

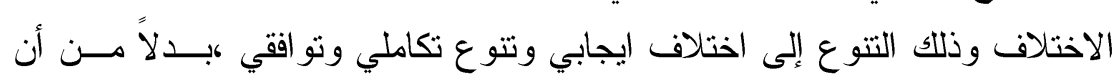

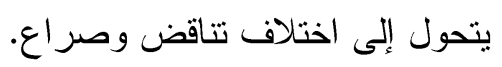

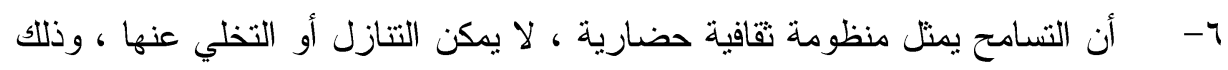

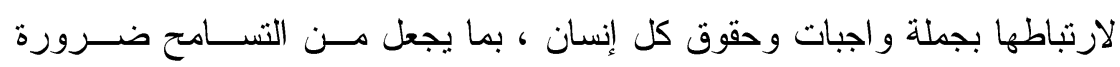
حتمية . لارتباط

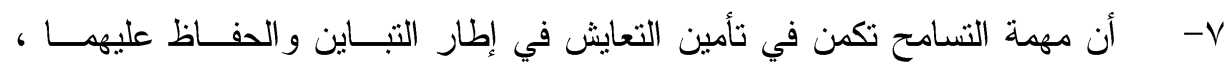
وحماية ما ينطويان عليه من مضامين اجتماعية للوجود الإنساني .

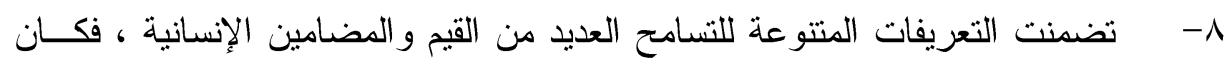

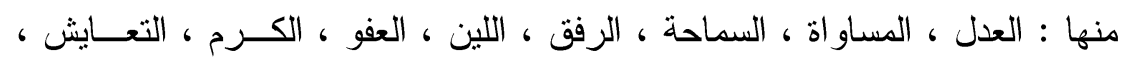

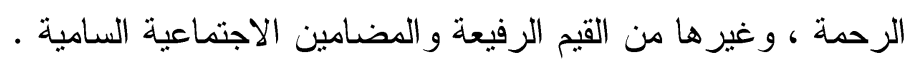

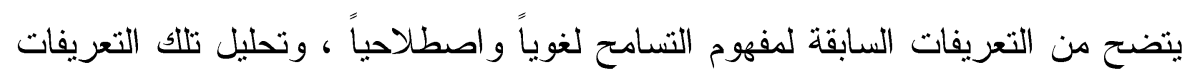

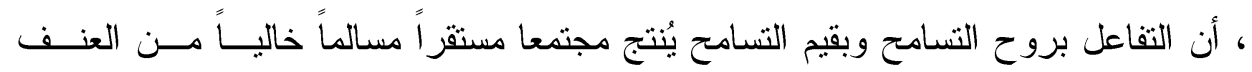

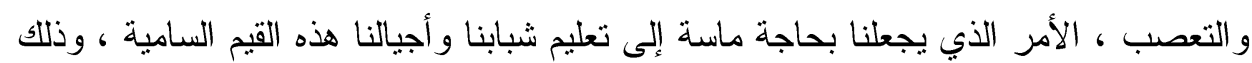

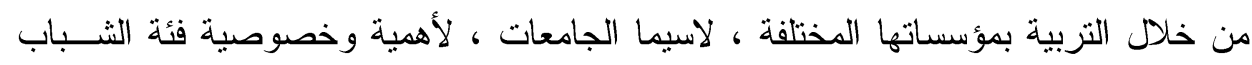

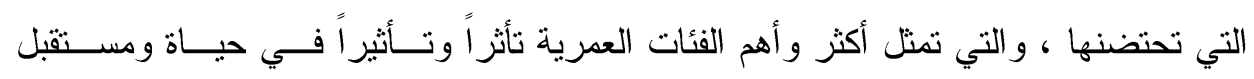
ثانياً: : عو ائق التسامح التسامح هو معالجة لقضية الإنسانية المعذبة بغيــاب التســامح و انحســاره ، فالتســامح

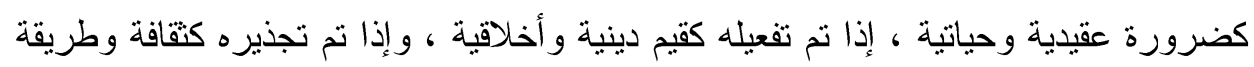

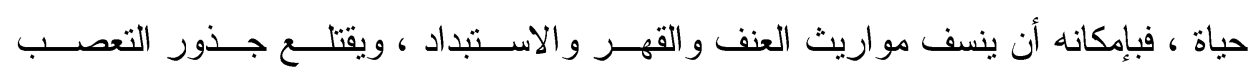
و الكر اهية.

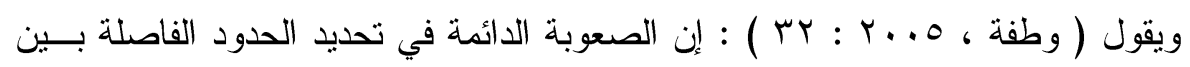
الخير و الثر وتغايرها وفقاً لتباين وجهات النظر ، هذه الصعوبة هي الأساس للعنف في الحياة

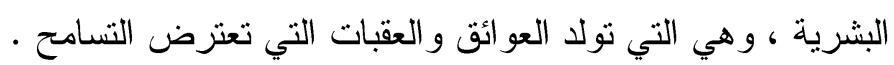

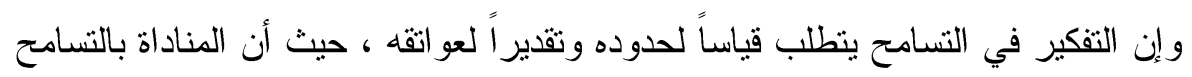

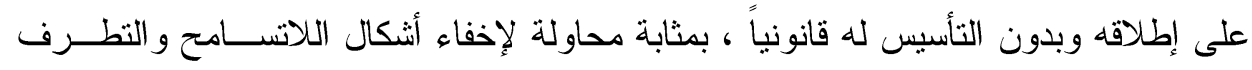

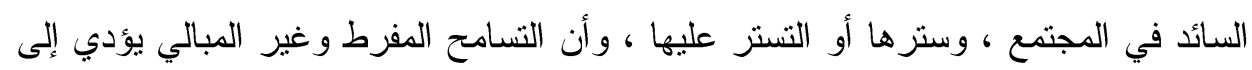

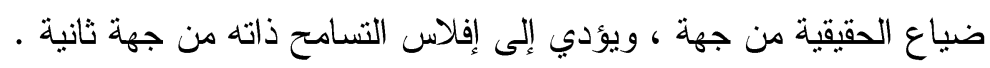




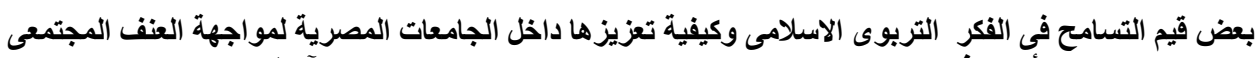
د/ آمال محمد ابر اهيم المهن

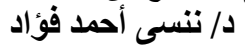

ولقد أكد على ذلك ( بغداد محمد ، 1. . r : 17 ) بقوله : إن التفكير في التسامح ينطلب

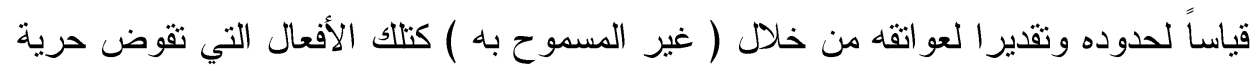

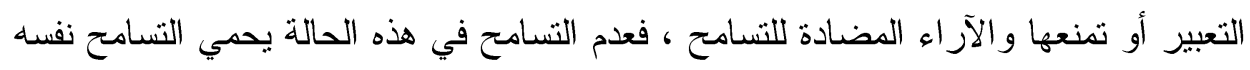

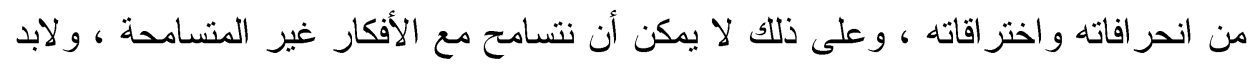

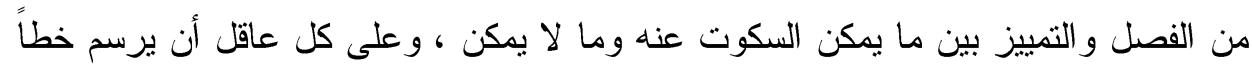

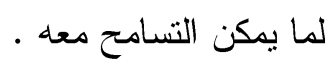
و هكذا يكون التسامح مشروطاً بالسماح لكل فرد في التفكير و التعبير عن آرائه من جهة

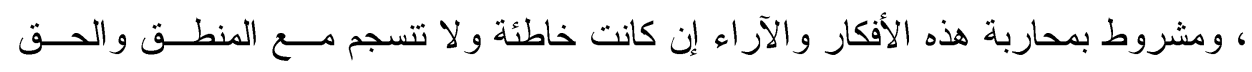
و الخير من جهة ثانية ، ولكن ذلك ييقى في إطار الحوار النقدي الذي يعلو إلى مرتبة أعلـى الإنى

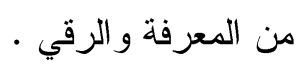

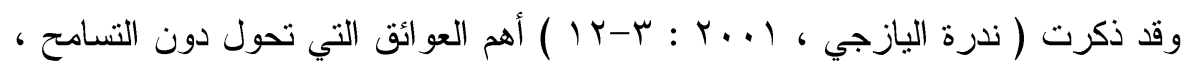

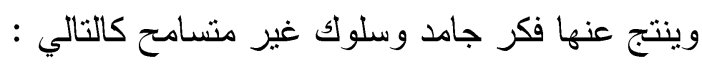

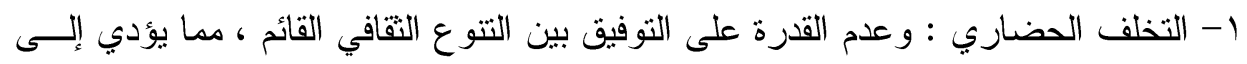

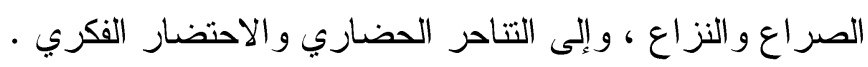

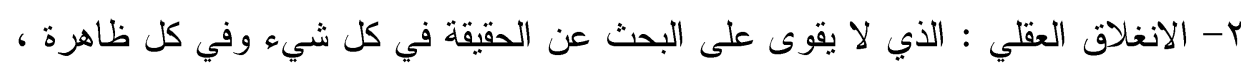

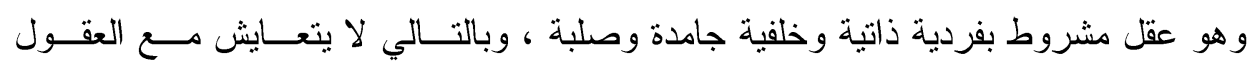

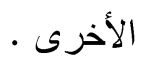
ب- جهل المنعلم : ذللك الجهل الذي ير افق المتعلم بحيث يجعل من علمه ثقافة تتمثل في رقي

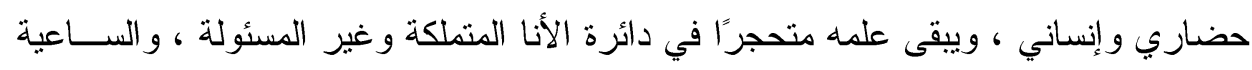
إلى مصلحتها الذاتية ع- إنكار العقل العام المشترك : فلابد من الاعتر اف بالعقل العام المشترك بين الناس ، حيث

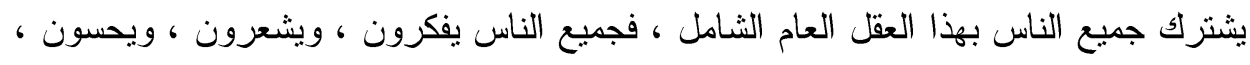

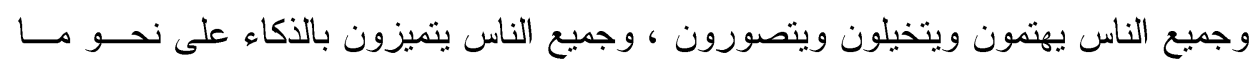

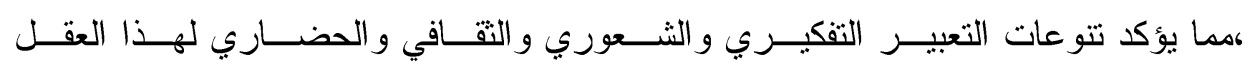

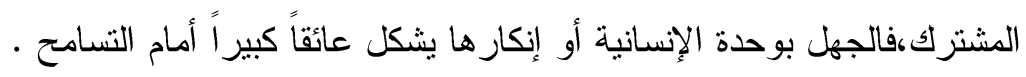

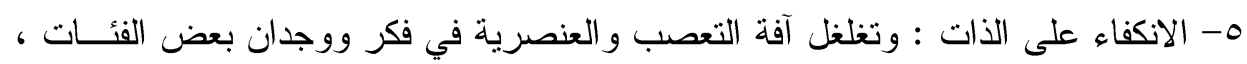

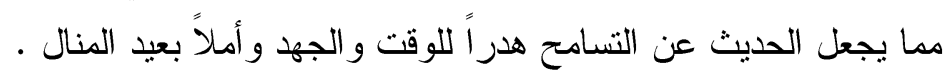

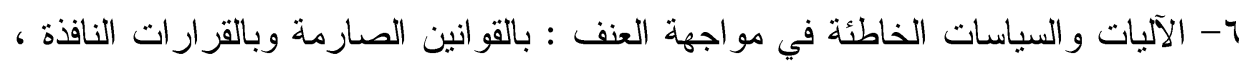

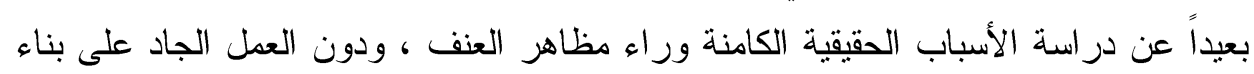


بعض قيم التسامح في الفكر التربوى الاسلامى وكيفية تعزيزها داخل الجامعات المصرية لمواجهة العنف المجتمعى د/ آمال محمد ابر اهيم المنف المجنم

د/ نتسى أحمد فؤاد الفري

الروح الإنسانية المناهضة للعنف ، حيث أن رفض العنف يجب أن ينبع من داخـل الأفــر اد

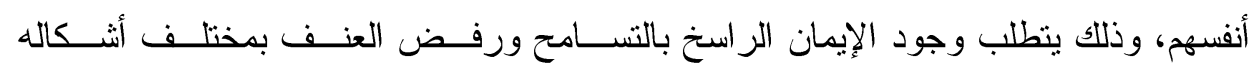
ومظاهره.

V- غياب شروط العدالة الاجتماعية و الديمقر اطية بمختلف مستوياتها : فقد بينـت الأبحـاث

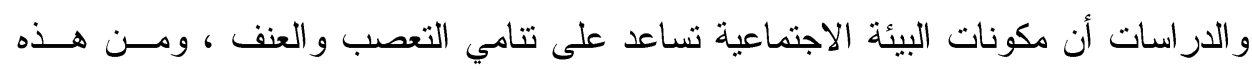

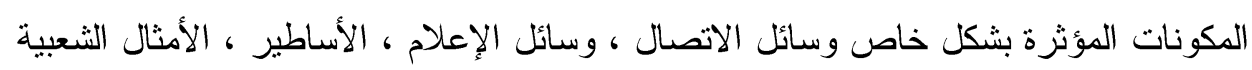

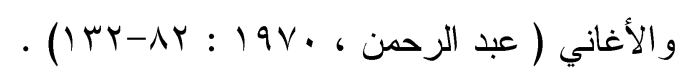

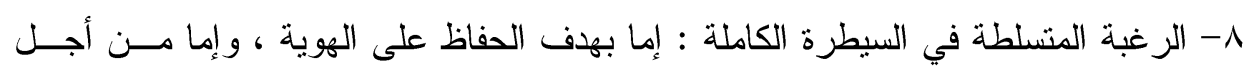

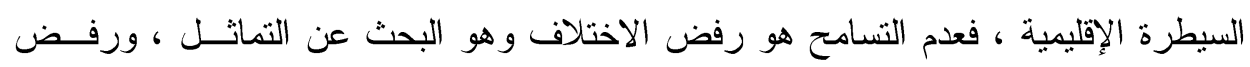

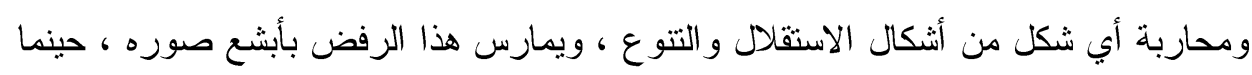

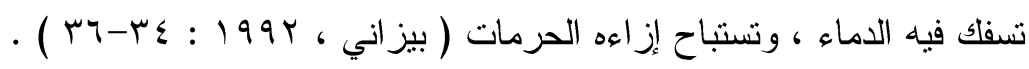

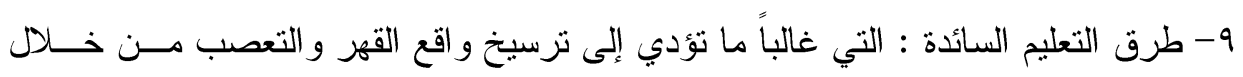

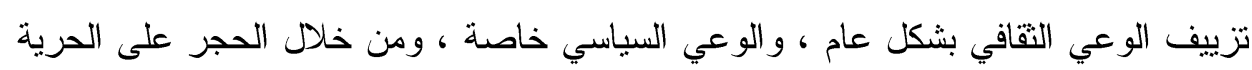

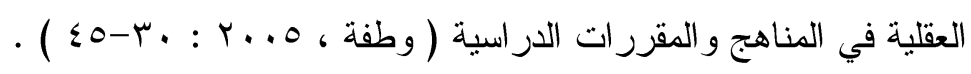

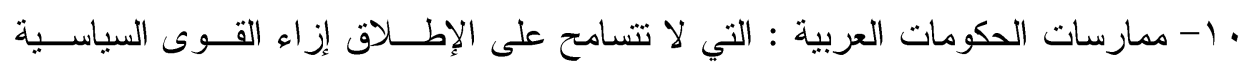

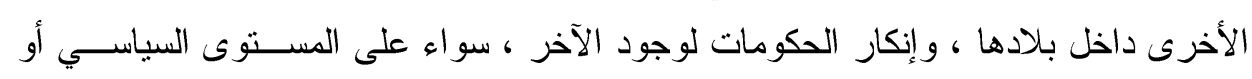

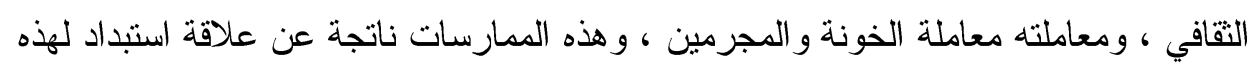

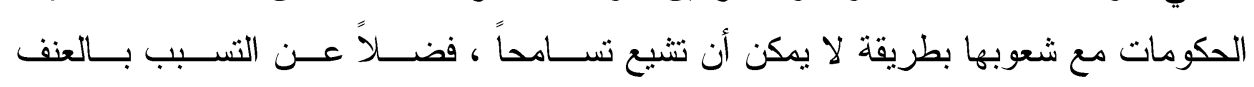

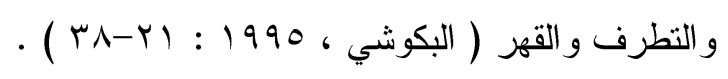

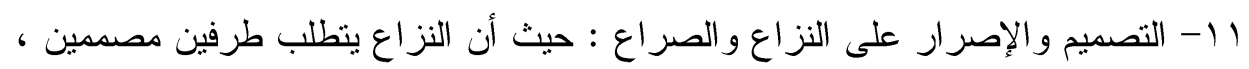

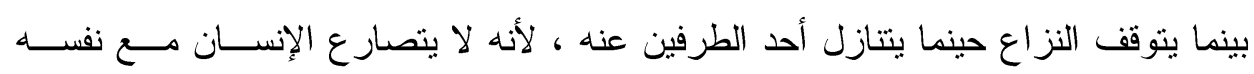

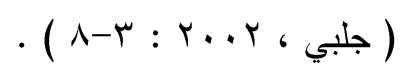

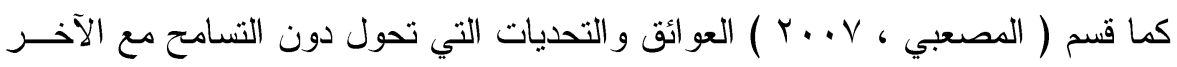

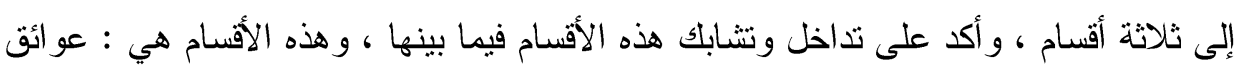

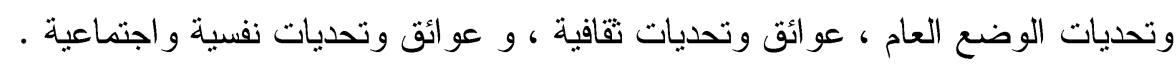

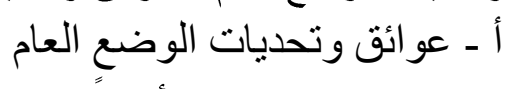

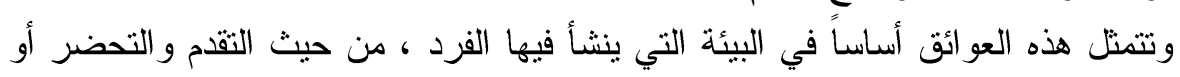

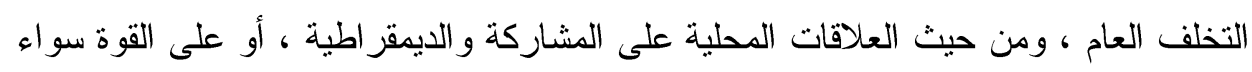

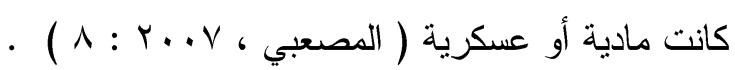


بعض قيم التسامح فى الفكر التربوى الاسلامى وكيفية تعزيزها داخل الجامعات المصرية لمواجهة العنف المجتمعى إلمال د/ آمال محمد ابر اهيم المهن

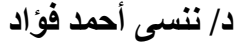

اـ التخلف العام : أن التحضر و التخلف ظاهرتان مجتمعيتان ، أب يتأثر بهما سائر نواحي ،

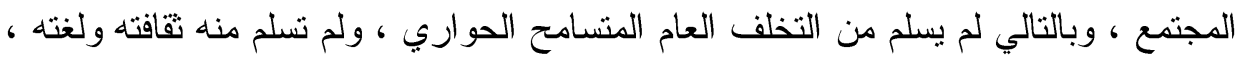

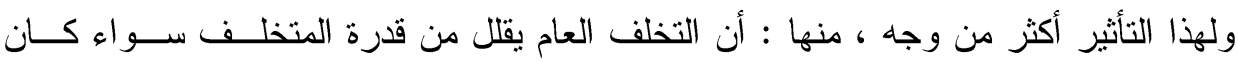

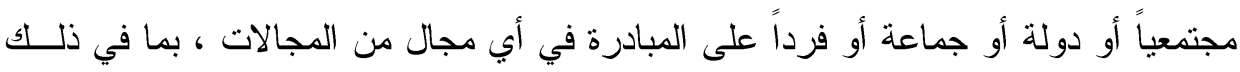

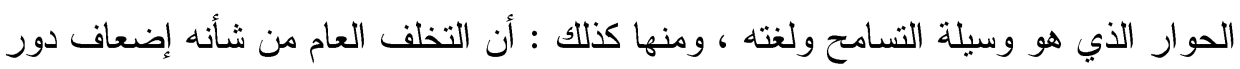

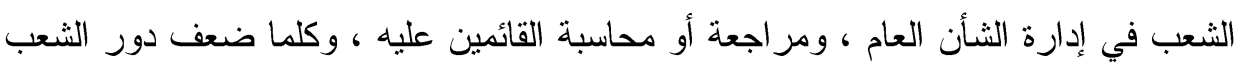

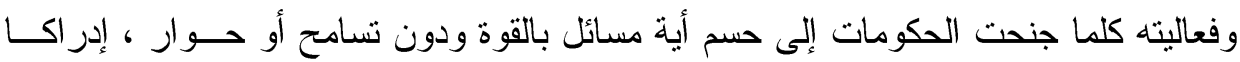

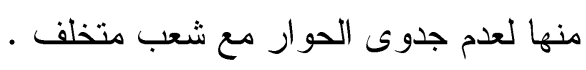
r ـ قيام العلاقات على القوة : إن من أبرز ملامح المجتمع المتخلف هو قيــام العلاقــات

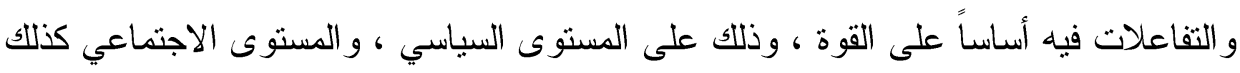

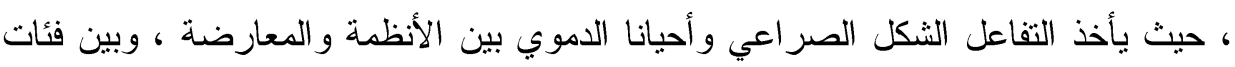

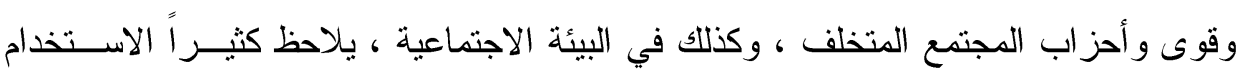

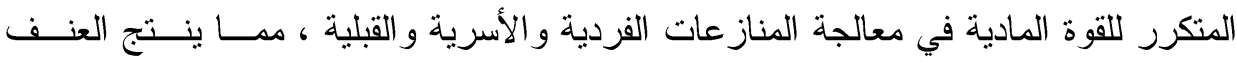

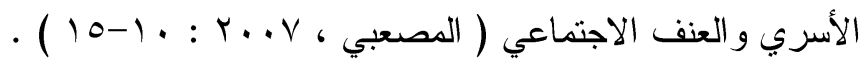

$$
\begin{aligned}
& \text { ب ـ العو ائق و التحديات الثنقافية }
\end{aligned}
$$

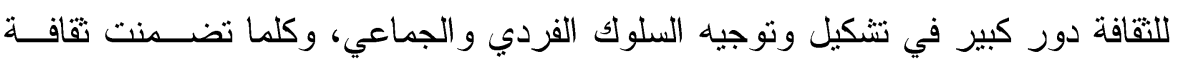

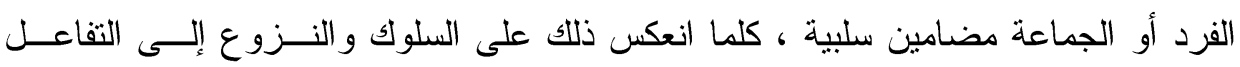

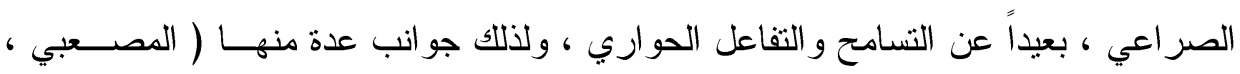
: (r.-17: r...V

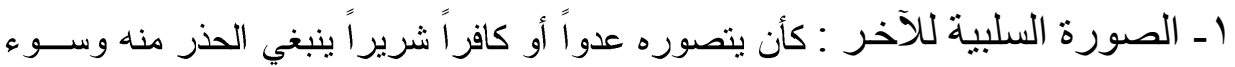

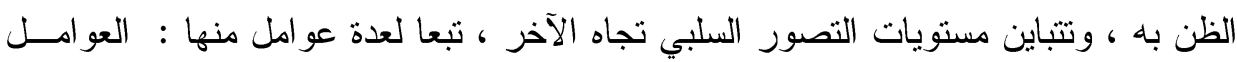

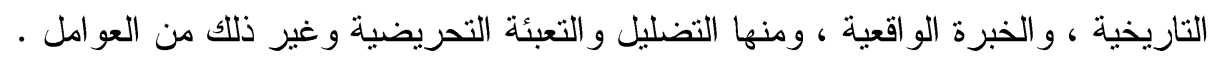

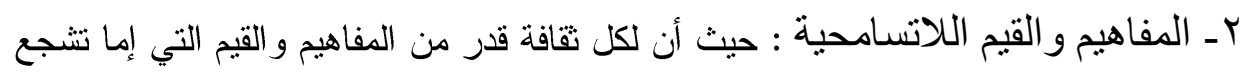

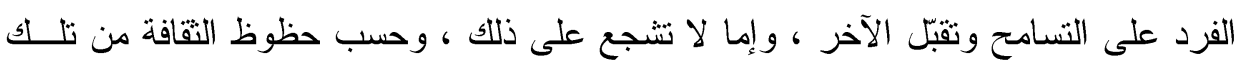

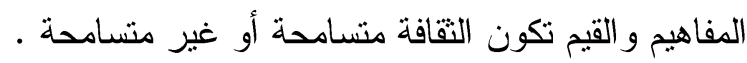

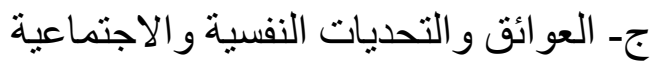

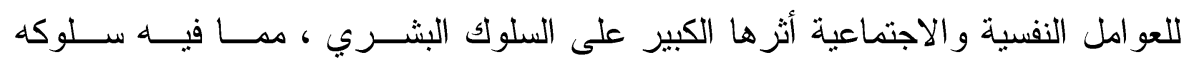

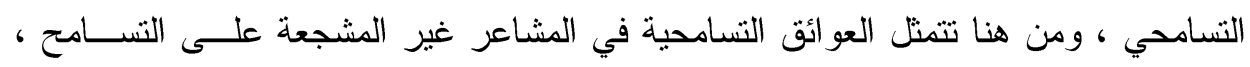


بعض قيم التسامح في الفكر التربوى الاسلامى وكيفية تعزيزها داخل الجامعات المصرية لمواجهة العنف المجتمعى

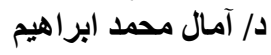

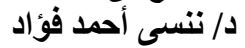

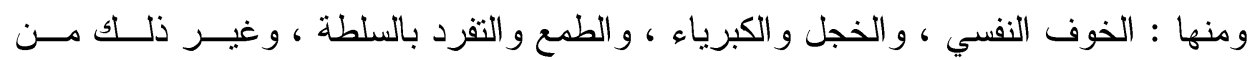
المشاعر و الصفات السلبية .

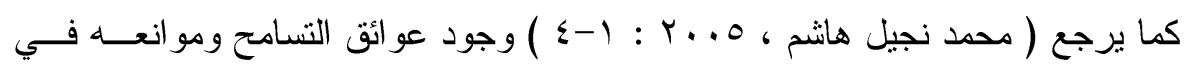

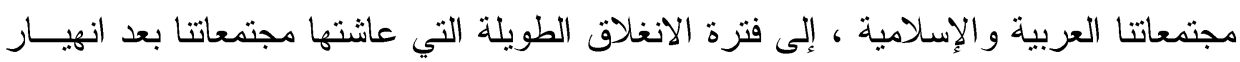

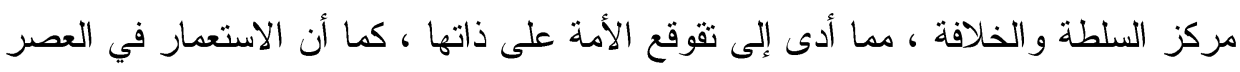

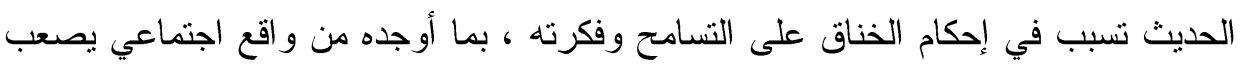

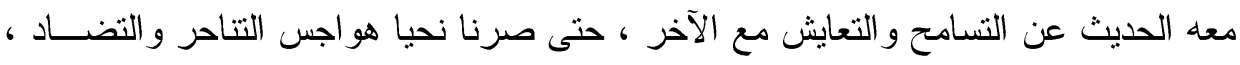

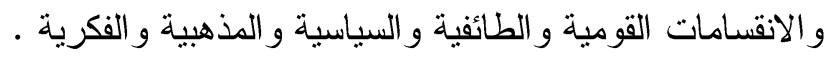

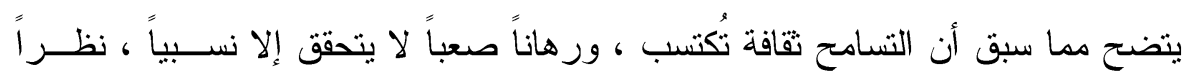

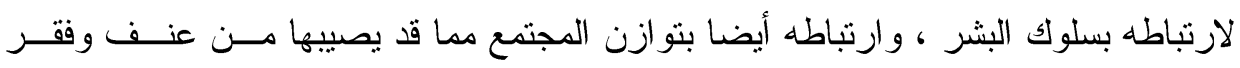
وحروب .

ومن هنا يمكن للجامعة أن تتجاوز الكثبر من هذه العقبات التي تعوق ممارسة التسامح ،

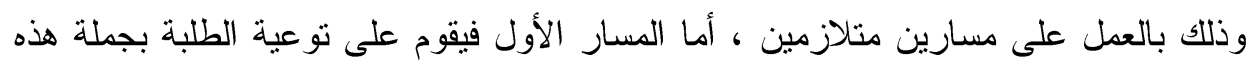

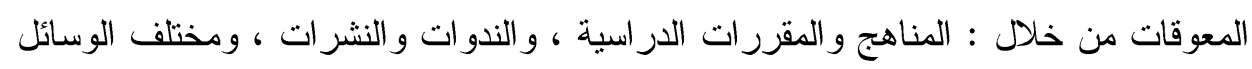

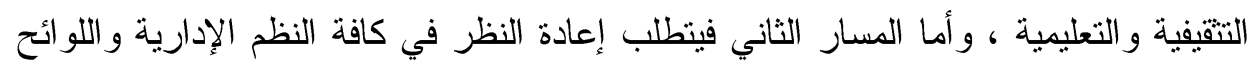

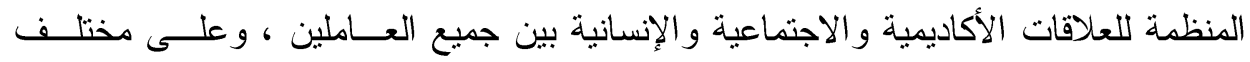

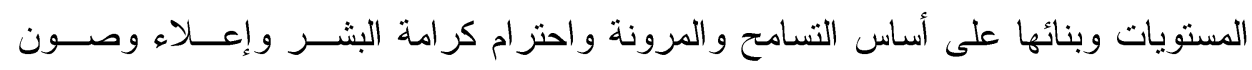
- إنسانيتهر :

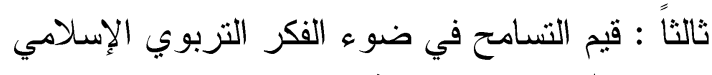

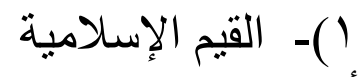
أـ مفهومها :

القيم الإسلامية هي القيم السستمدة من الدين الإسلامي الحنيف ، الذي يَعتبر ( الحسـن )

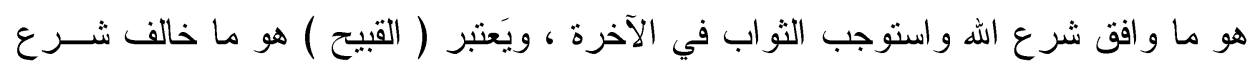
الله ويترتب عليه العقاب في الآخرة. فالمنظور الإسلامي ينظر إلى القيم على أنها " مجموعة الأو امر المستمدة من كتــاب الله

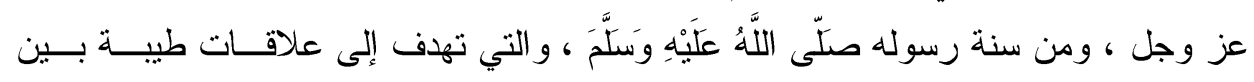

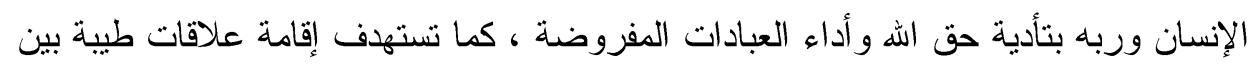

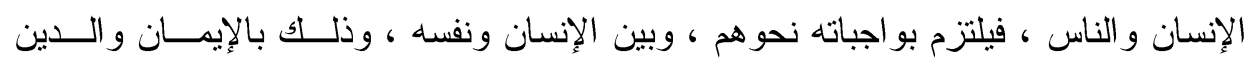

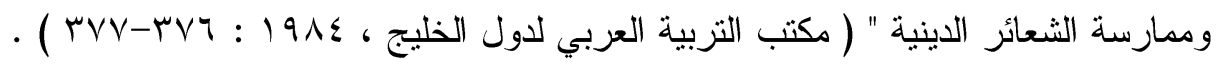


بعض قيم التسامح في الفكر التربوى الاسلامى وكيفية تعزيزها داخل الجامعات المصرية لمواجهة العنف المجتمعى د/ آمال محمد ابر اهيم المنف المجنم

د/ نتسى أحمد فؤاد الدي

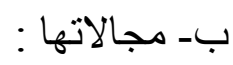

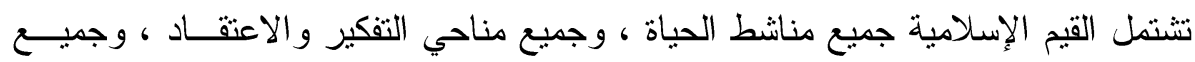
العلاقات التي تربط المسلم بخالقه وبغيره من البشر ، بل وبالكون جميعاً. .

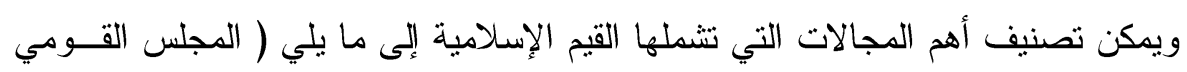

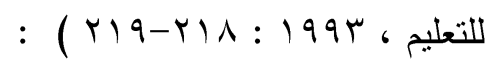

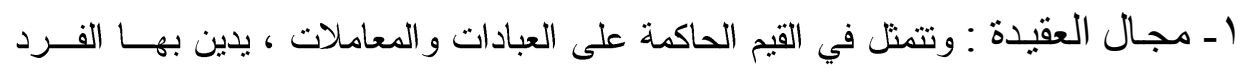

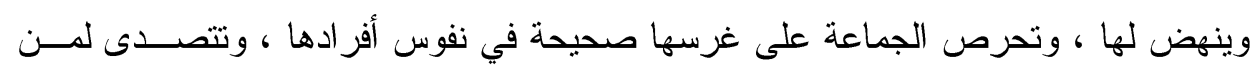

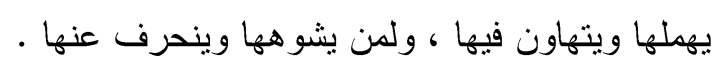

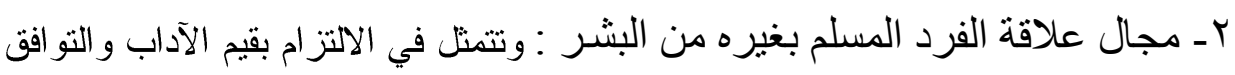

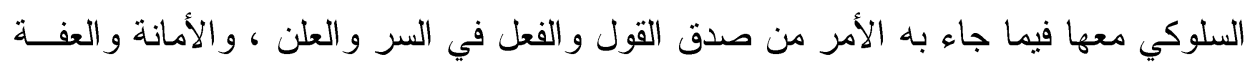

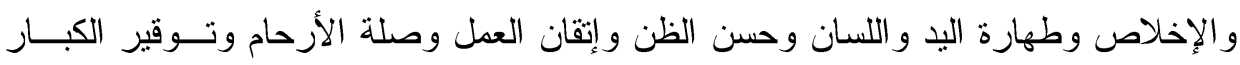

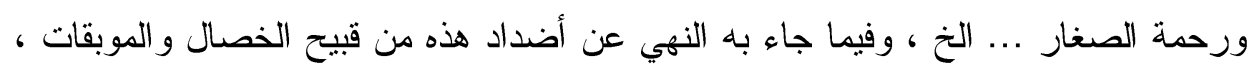

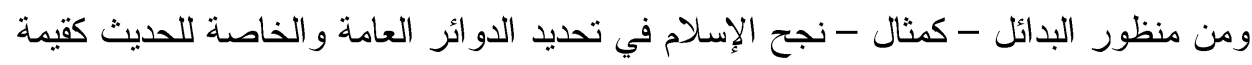

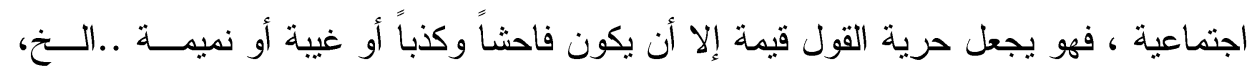

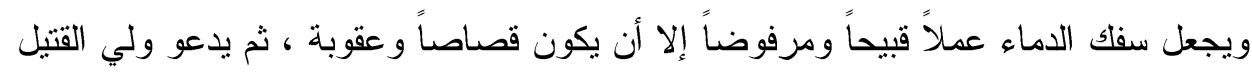

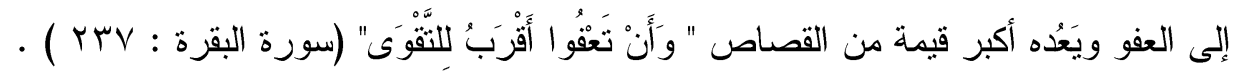

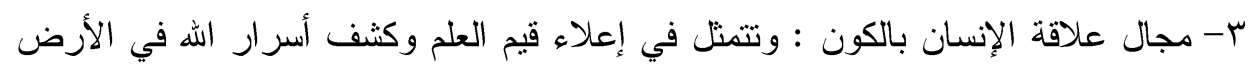

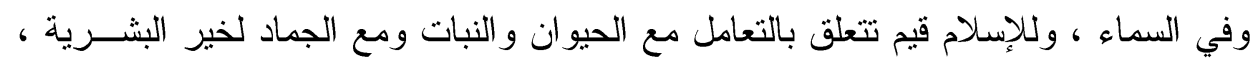

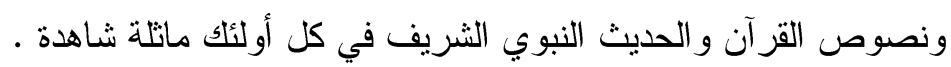

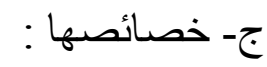
القيم الإسلامية تتميز بخصائص تميز ها عن القيم في المجتمعات غير الإســلامية ، وهـــه

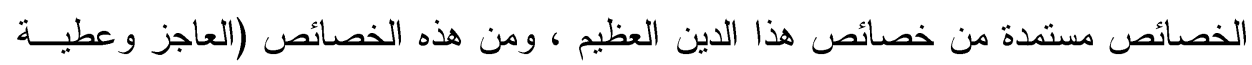
العمري ، 1999

1- الربانيـة : فالقيم الإسلامية ربانية المصدر ، بمعنى أنها مستمدة من كتاب الهه وسنة

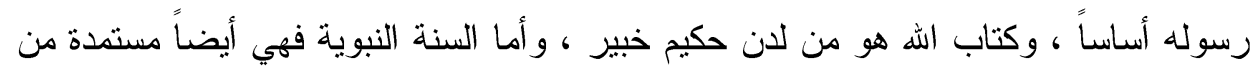

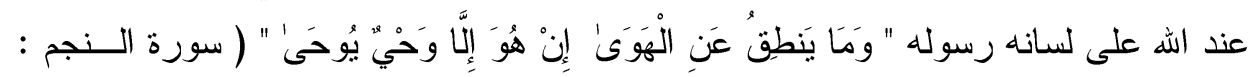

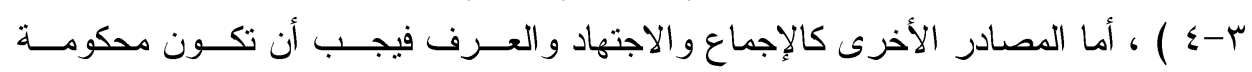

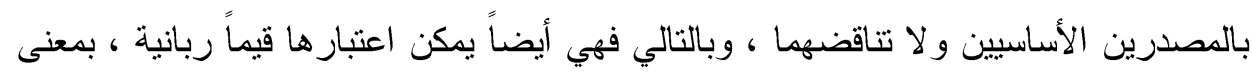

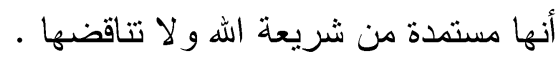


بعض قيم التسامح في الفكر التربوى الاسلامى وكيفية تعزيزها داخل الجامعات المصرية لمواجهة العنف المجتمعى آلمال د/ آمال محمد ابر اهيم المهن

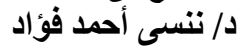

ويتضح مما سبق أن كون القيم الإسلامية ربانية المصدر لا ينفي دور العقل في الاجتهــاد

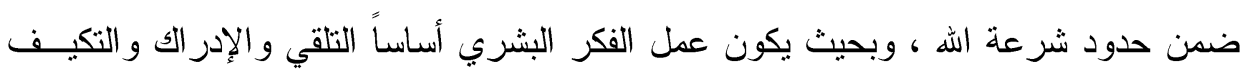

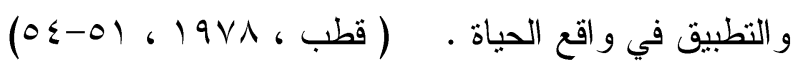
r- - الثبـات : و الثبات هنا لا يعني الجمود ، بل هو كما يقول ســيد قطــب " خاصــية الحركة داخل إطار ثابت حول محور ثابت " . ويقول:" هناك ثبات فــي مقومــات التصــور الإسلامي وقيمه الذاتية ، فهي لا تتغير ولا تتطور حينما تتغير ظو اهر الحياة الو اقعية وأثكال

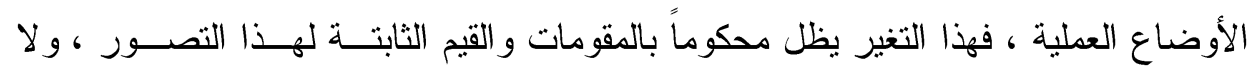
يقتضي هذا " تجميد " حركة الفكر و الحياة ، ولكنه يقضضي السماح لها بالحركة - بل دفعهــا

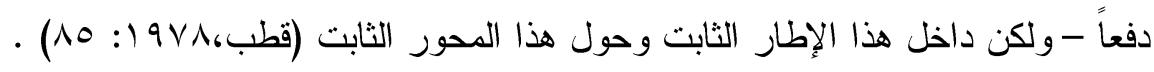
س- - الثـمول : فالقيم الإسلامية تتمثل فيها صفة الثمول من نواح عدة : فهي شاملة لكل

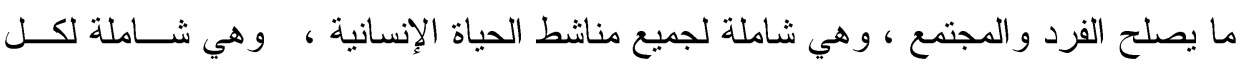
العلاقات التي تزبط المسلم بغيره سواءً علاقته بربه أو بالمسلمين أو غير المسلمين أو علاقته

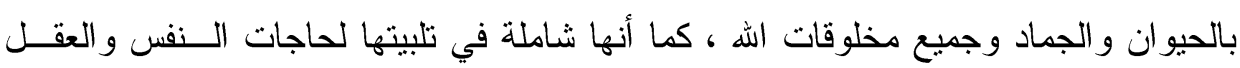

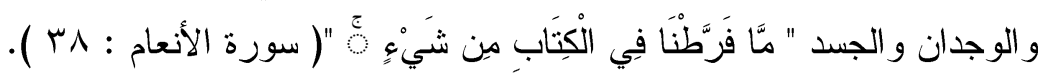
ع- - التوازن : فهنالك التوازن و الوسطية وعدم الإفر اط أو التفريط ، وهذا التو ازن يظهر بمظاهر شتى : فهناك نوازن بين الجانب الذي تتلقاه الكينونة الإنسانية لتدركة وتسلّمّ به وبين الجانب الذي تتلقاه لتدركه وتبحث حججه وبر اهينه وتحاول معرفة علله وغاياته وتقكر فـي مقتضياته العملية وتطبقها في حياتها الو اقعية ، وهناك توازن بين متطلبات الفرد ومتطلبــات

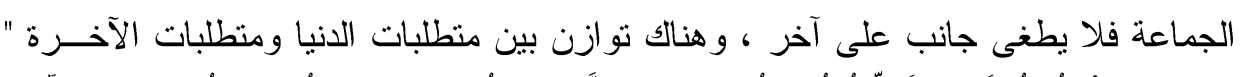

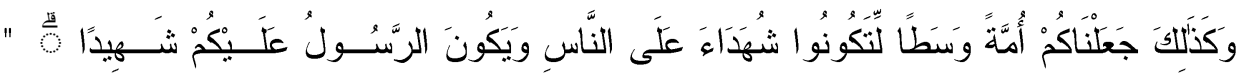

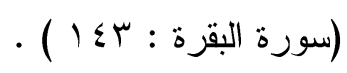

ه- - الإيجابية : فالقيم الإسلامية قيم إيجابية بكل ما تعني هذه الكلمة ، فهي إيجابية خيرة تؤدي بمن بعتققها إلى سعادة الدنيا و الآخرة ، وهي إيجابية فاعلة في علاقة الله سبحانه بالكون و الحياة والإنسان ، وهي إيجابية فاعلة في دور الإنسان ووظيفته في هذا الكون .

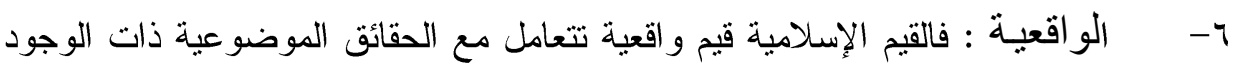
الحقيقي المستيقن و الأثز الو اقعي الإيجابي ، لا مع تصورات عقلية مجردة ، و لا مع مثاليــات

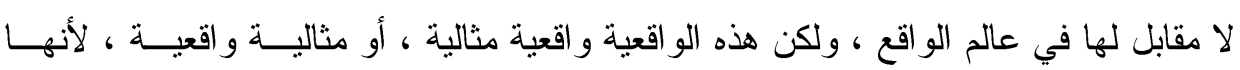
تهدف إلى أرفع مستوى و أكمل نموذج تملك البشرية أن تصعد إليه . 
بعض قيم التسامح في الفكر التربوى الاسلامى وكيفية تعزيزها داخل الجامعات المصرية لمواجهة العنف المجتمعى د/ آمال محمد ابر اهيم المنف المجنم

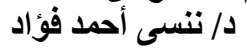

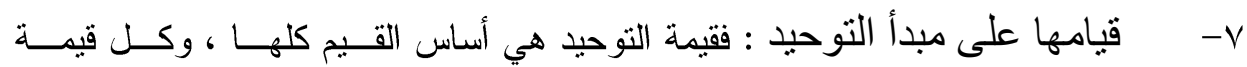

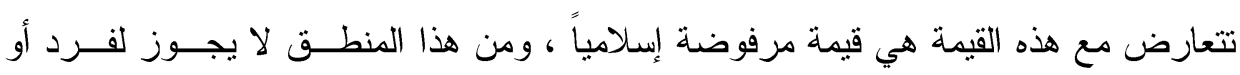

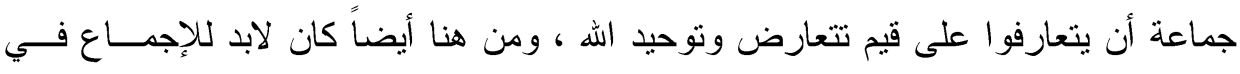

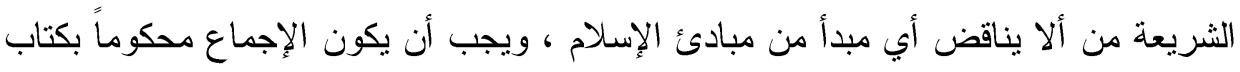

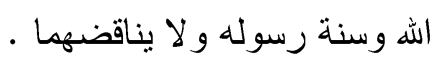

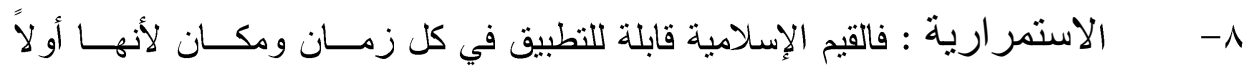

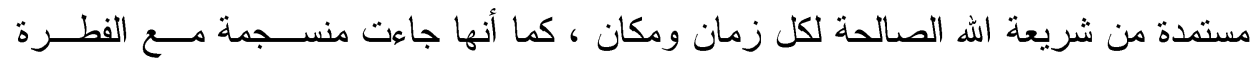

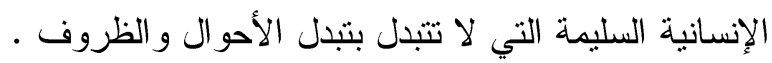

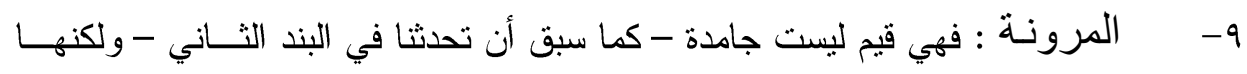

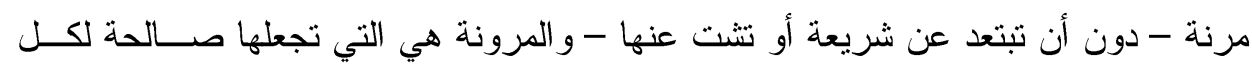

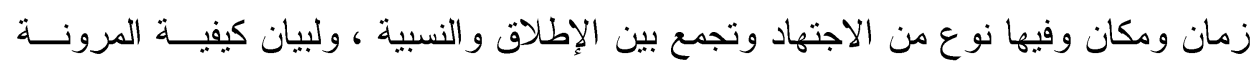

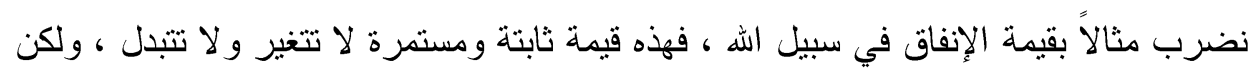

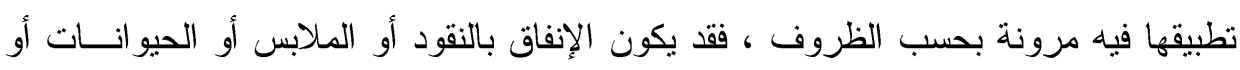

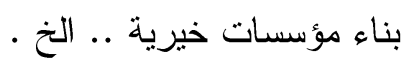

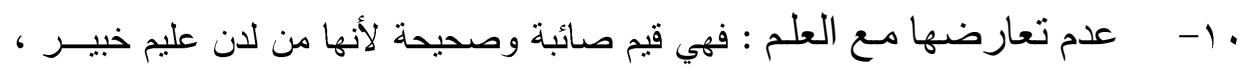

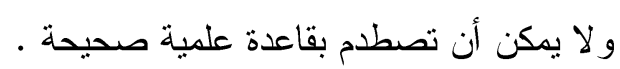

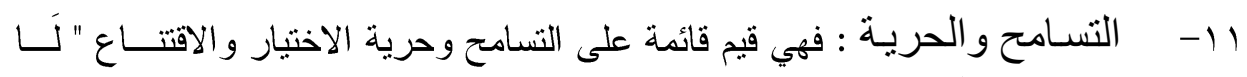

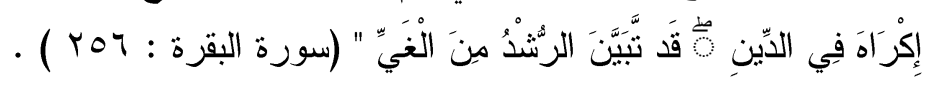

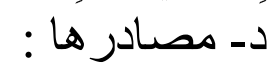

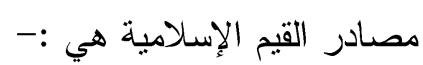

ا- القرآن الكريم : القرآن الكريم هو أساس الثريعة الإسلامية و أصل سائر أدلتهـــا فــال

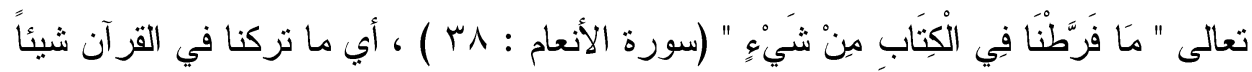

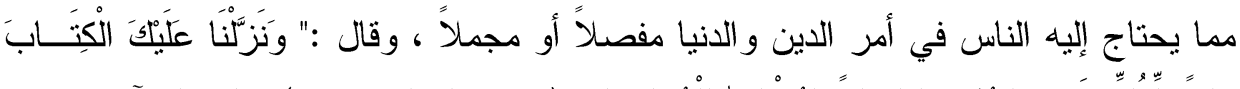

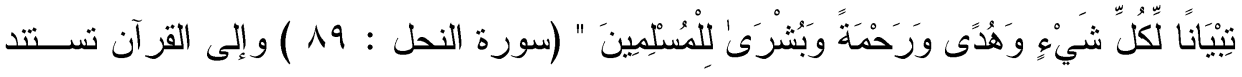

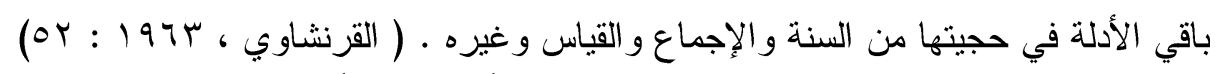

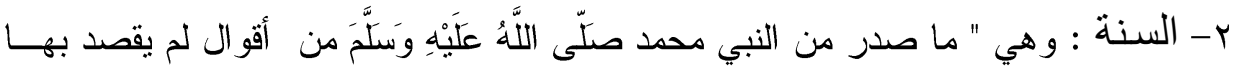

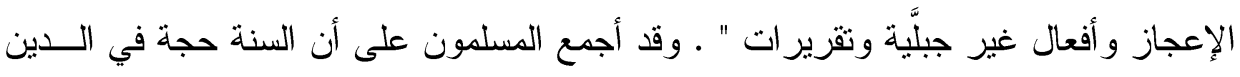

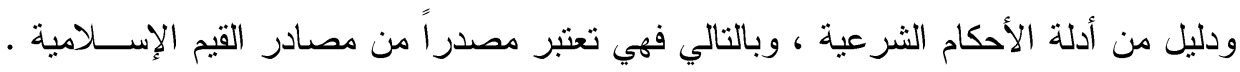

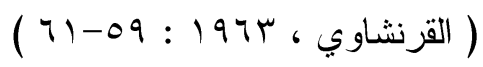


بعض قيم التسامح فى الفكر التربوى الاسلامى وكيفية تعزيزها داخل الجامعات المصرية لمواجهة العنف المجتمعى إلمال د/ آمال محمد ابر اهيم المهن

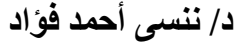

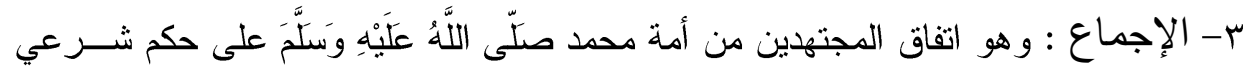

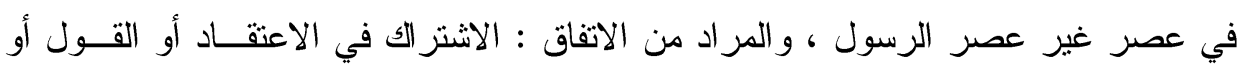

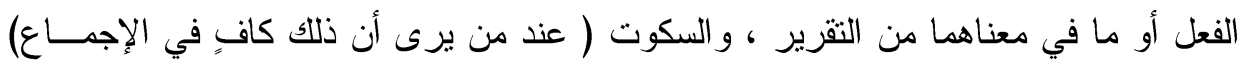

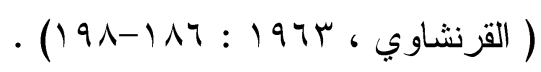

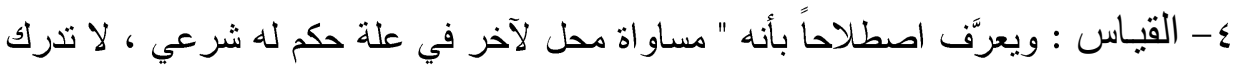

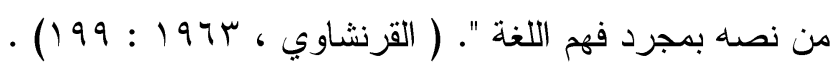

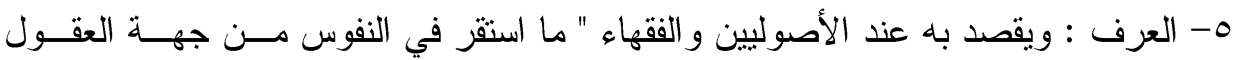

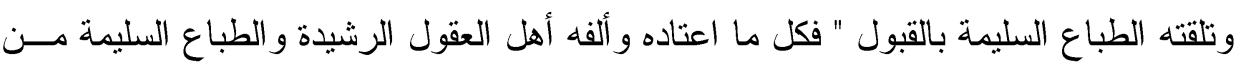

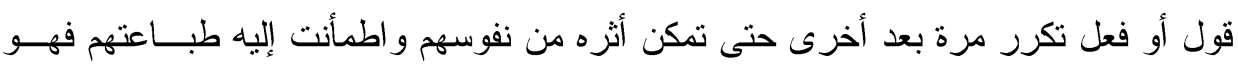

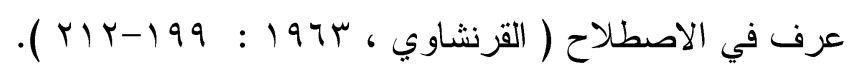

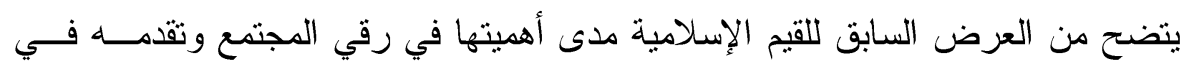

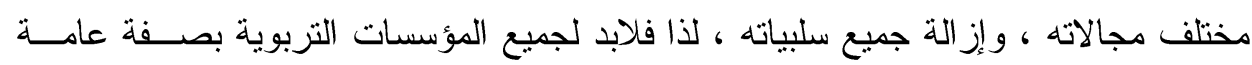

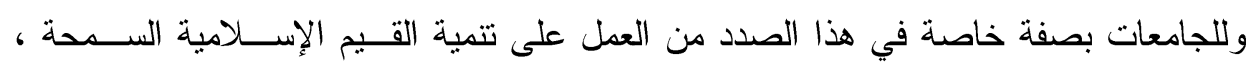

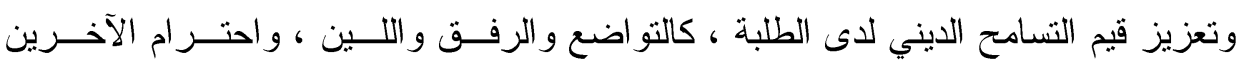

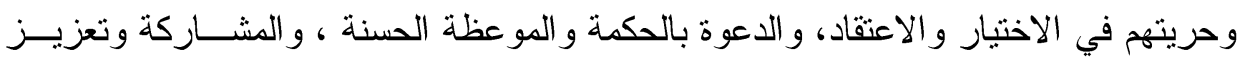

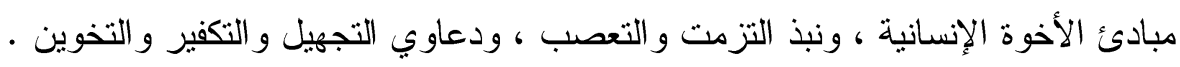

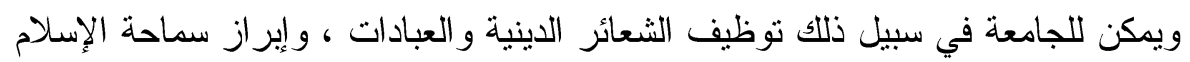

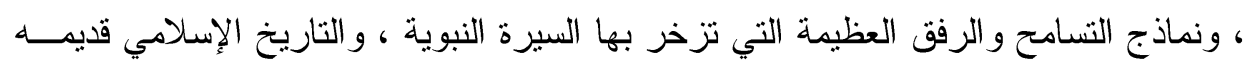

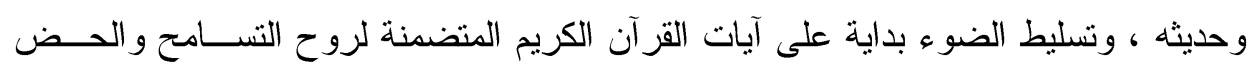

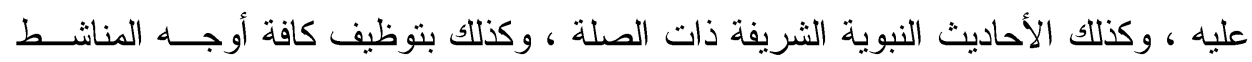

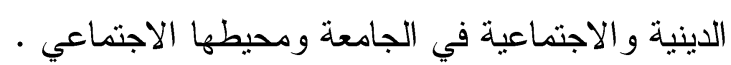

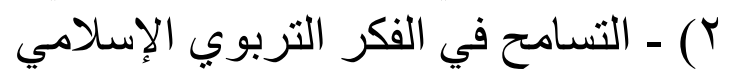

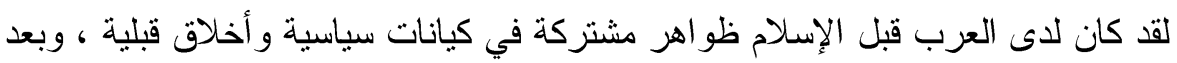

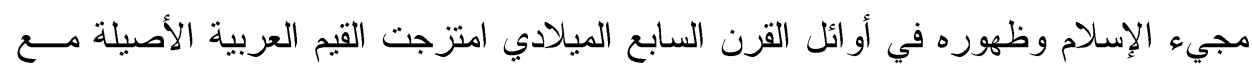

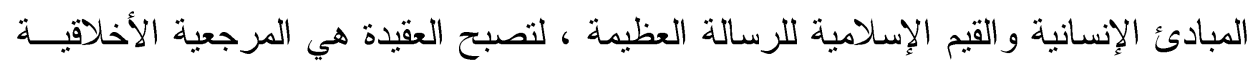

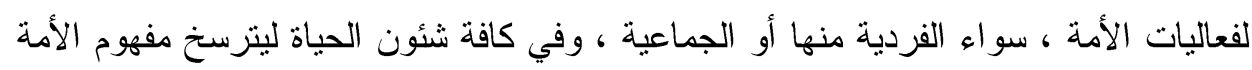

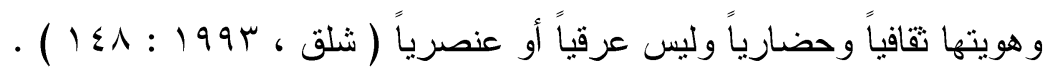

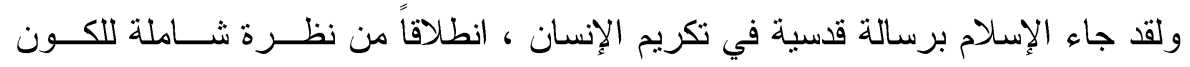

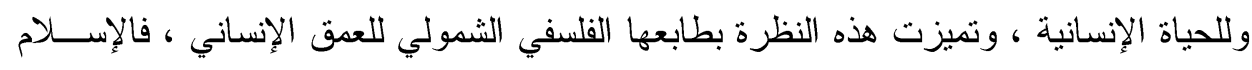


بعض قيم التسامح في الفكر التربوى الاسلامى وكيفية تعزيزها داخل الجامعات المصرية لمواجهة العنف المجتمعى آلمال د/ آمال محمد ابر اهيم المهن

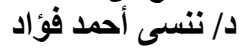

دين عالمي يتجه برسالته إلى البشرية كلها ، تلك الرسالة التي تأمر بالعدل وتتهي عن الظلـــ وترسي دعائم الأمن و السلام على الأرض ، وتدعو إلى التعايش الايجابي بين البشر جميعاً ،

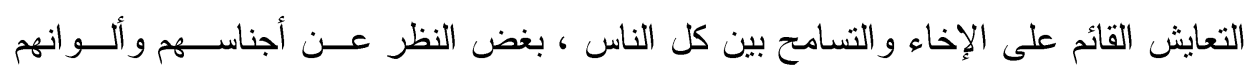

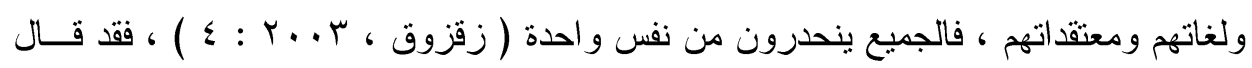

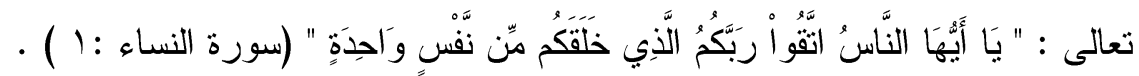
فالإنسان هو هدف الإسلام ، لذلك نظم الإسـلام علاقات الإنسان على أسس من المحبــة

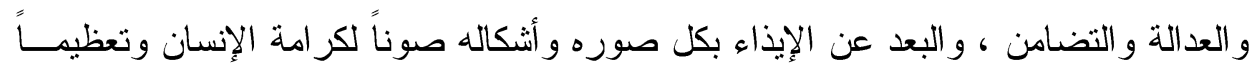

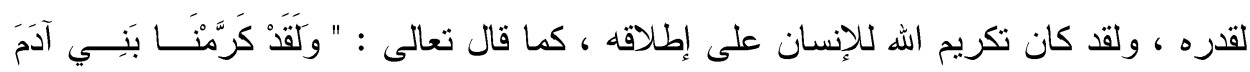

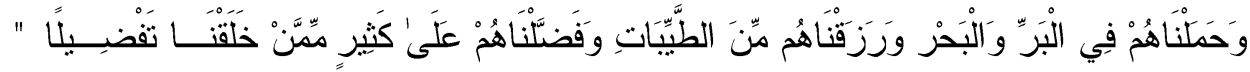
(سورة الإسر اء : V ) ، فلم يكن التكريم لجنس دون آخر أو لأصحاب دين معين دون سائر الأديان أو للرجال دون النساء الاءلراء ،

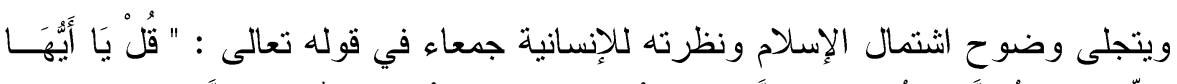

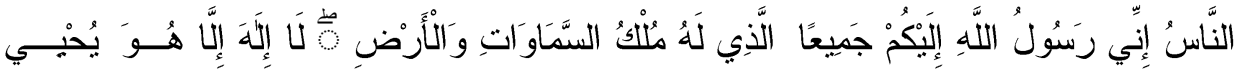

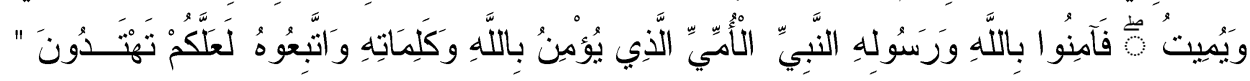

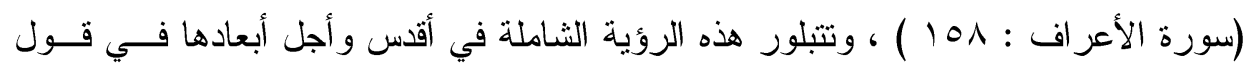

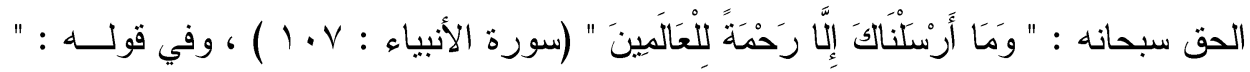

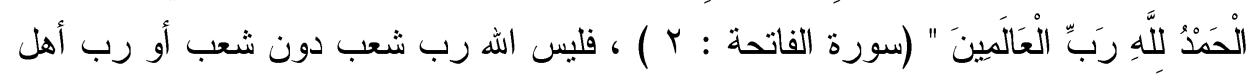

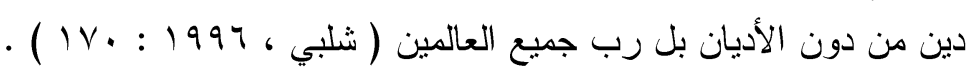

وفي هذه الآيات البينات بيان قطعي الدلالة على مكانة الإنسان وعظمته في الإســلام ، حيث تتجاوز حدود ما يسمى بحقوق الإنسان ، إلى صيغة أصيلة جامعة تتمثل فــي كر امـــة الإنسان ، التي هي جوهر كل حق ، وغاية كل مسعى ، لتحقيق حريات الإنسان وحقوقــهـ ،

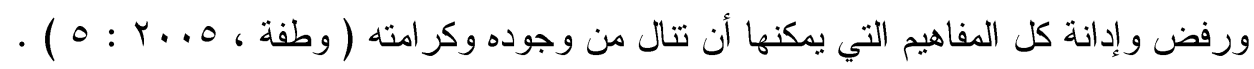

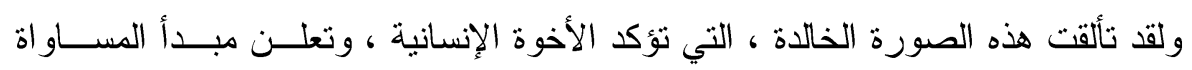

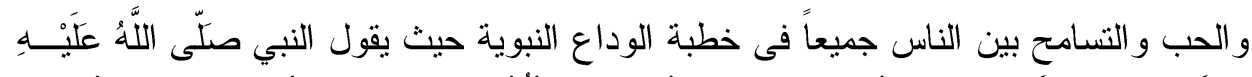

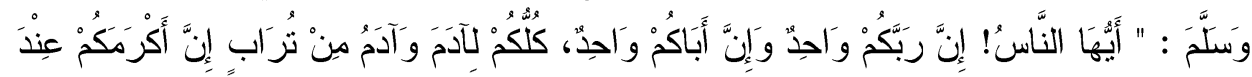

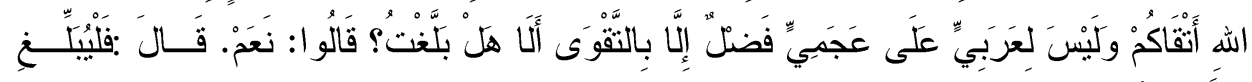

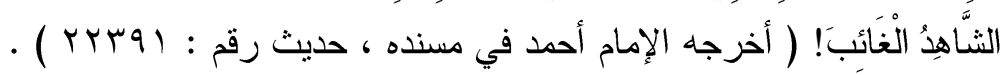


بعض قيم التسامح فى الفكر التربوى الاسلامى وكيفية تعزيزها داخل الجامعات المصرية لمواجهة العنف المجتمعى آمال د/ آمال محمد ابر اهيم المهن

د/ تنسى أحمد فؤاد الفئر

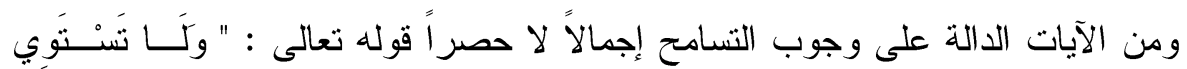

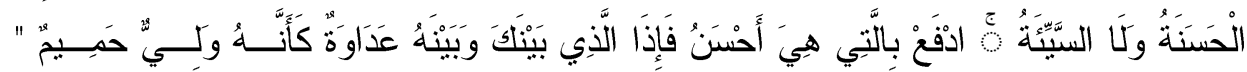

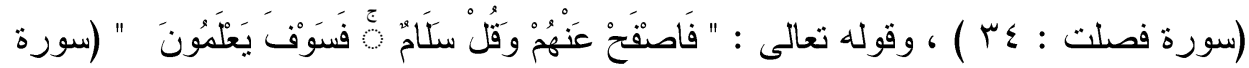
الزخرف : 9 ) ) ، ففي الآية الأولى أمر من الله عز وجل في كل عصر بمواجهــة الســيئة بالحسنة ، وفي الآية الثانية خطاب من الله تعالى لنبيه و أمته بالصفح وتزك المؤاخذة ، و هــذا الأمر يتضمن النهي عن الانتقام والمؤاخذة ، وقرن الله تعالى الصفح بقول سلام ، و السلام هو

الأمل المنشود الذي سعى إليه المسلمون عبر تاريخهم الطويل ( جمعة ، ع . . ب : ع ) . ولعل أروع الأمتلة على التسامح في تاريخ الإنسانية ، تسامح النبي الأكرم في تعامله مع

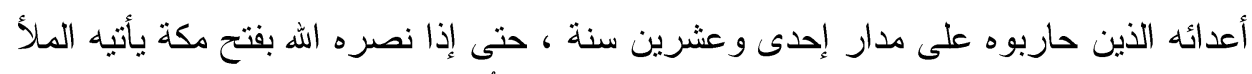

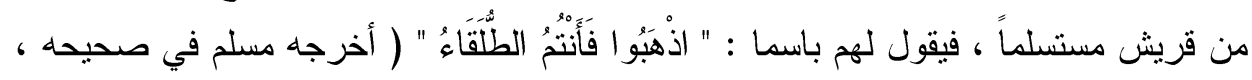

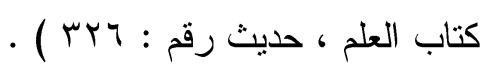

وقد تعايش في ظل الإسـام وحكمه أقو ام وشــعوب ، وعـروق وقوميــات ، وأجنــاس وثقافات مختلفة ، وكان الفاتحون العرب أكثر الفاتحين تسامحاً في التاريخ ، ولقد بلغ الإسلام

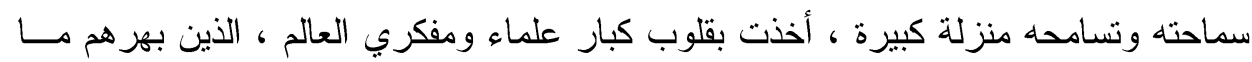
تميز به هذا الدين القويم من قيم التسامح و الحب و العدل و المساواة ، حيـــث يقــول المــؤرخ ( غوستاف لوبون) في كتابه تاريخ العرب : ما عرف التاريخ فاتحاً أعدل و لا أرحــم مــن العرب ، ويقول ( أرنولد توينبي ) في كتابه الدعوة إلى الإسلام : لقد كانت هـــه المعاملــة

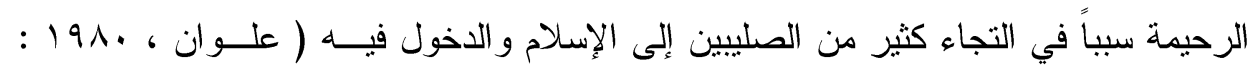
107 - 101 ) ، كما يقول (واثنجتون إرفنج ) وهو مستشرق ومؤرخ غربي : إن من أبرز

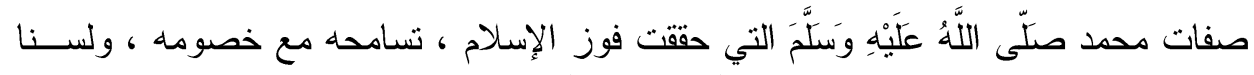

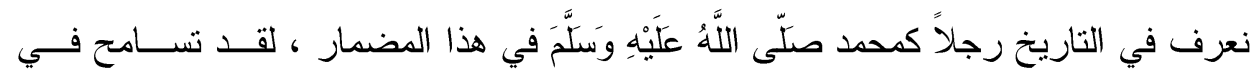
أوقات كان الزعماء في أمثالها ينكلون ممن كانو ا معارضين لهم تتكيلاً بشعاً ، ولكن تنــامح

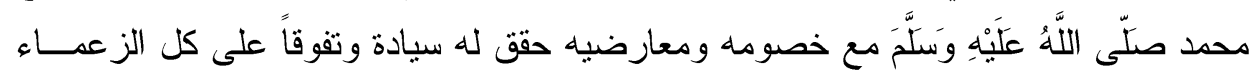

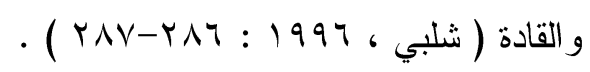

ولقد ضمن الإسـام حرية الاعتقاد للمسلمين ، ومنع الإكر اه في الدين ، و أقــر التشــامح

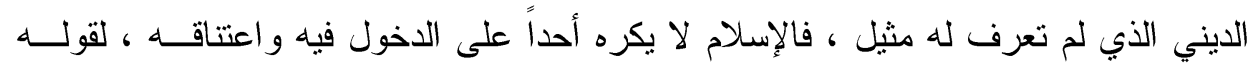

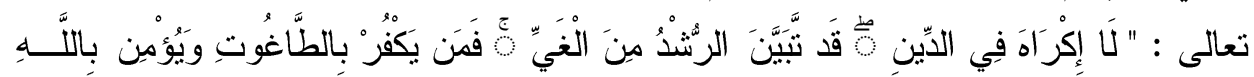

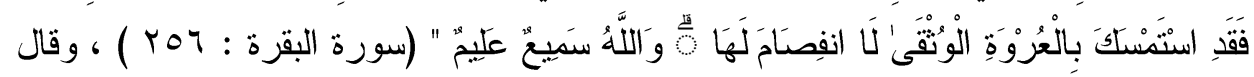


بعض قيم التسامح في الفكر التربوى الاسلامى وكيفية تعزيزها داخل الجامعات المصرية لمواجهة العنف المجتمعى آلمال د/ آمال محمد ابر اهيم المهن

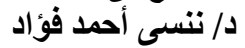

ابن كثير في هذا السياق : " أب لا تكرهوا أحداً على الدخول في دين الإسلام ، فانـــهـ يقـين و اضح ، جلي في بر اهينه ودلائله " .

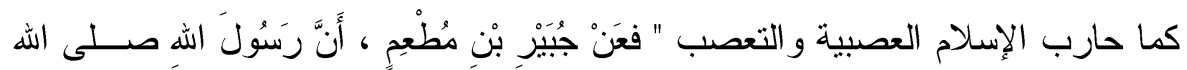

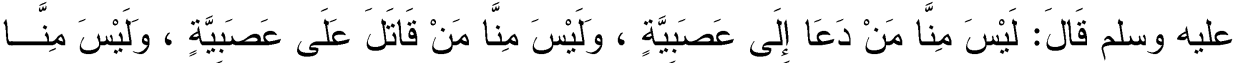

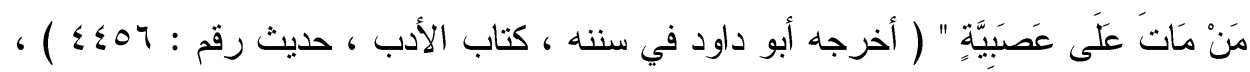

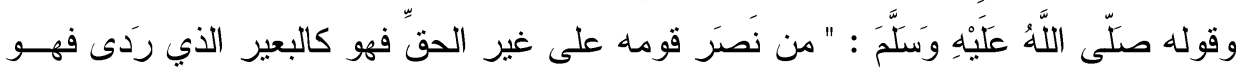

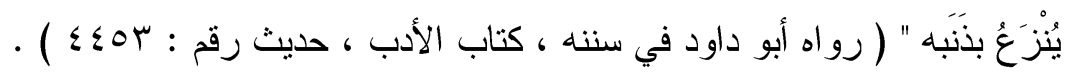

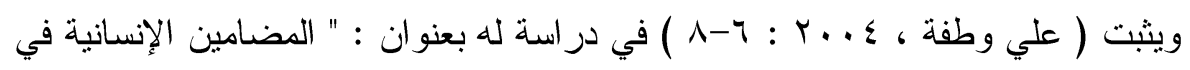

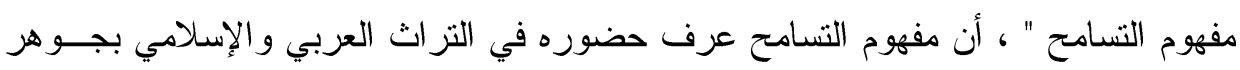

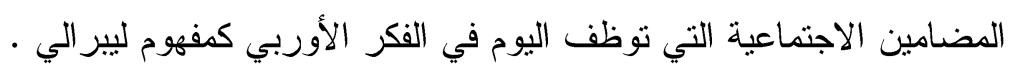

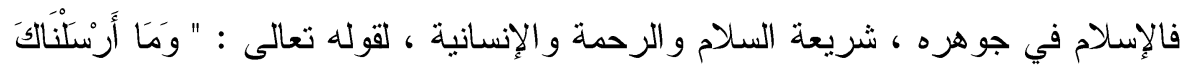

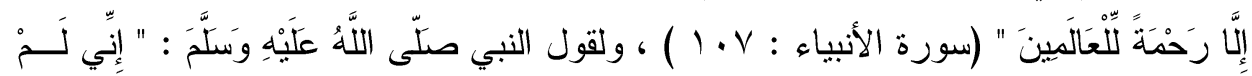

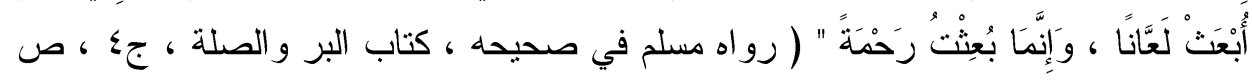

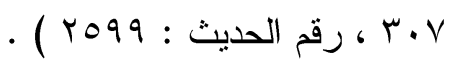

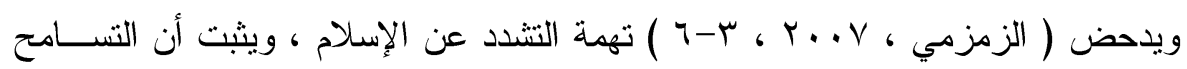

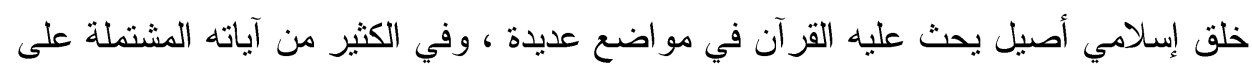

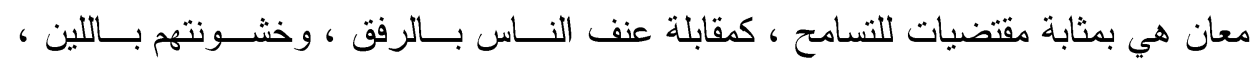

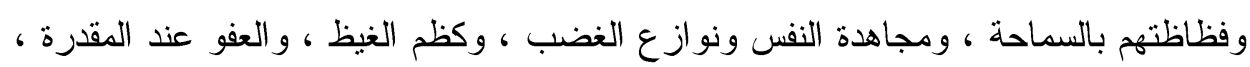

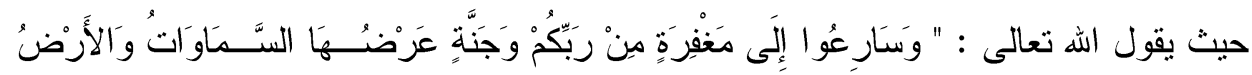

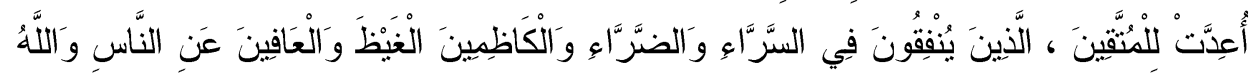

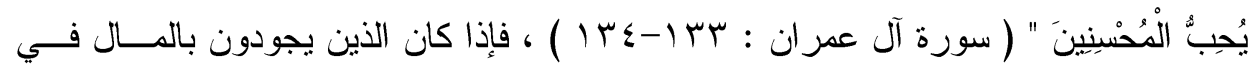

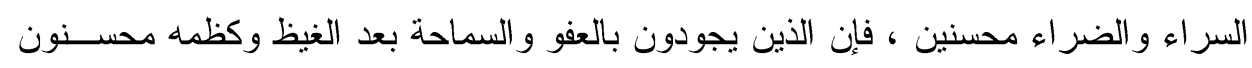

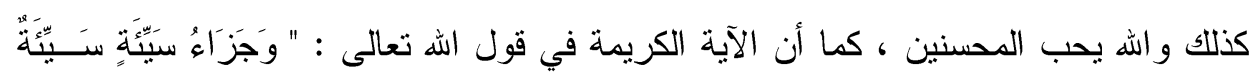

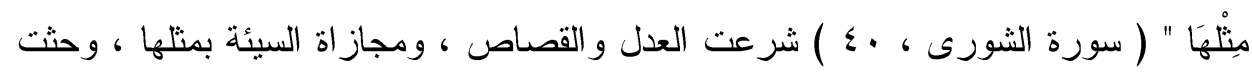

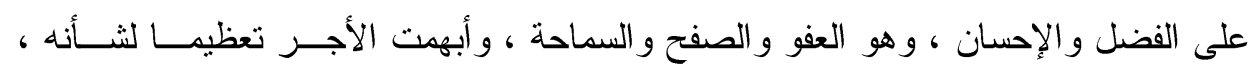

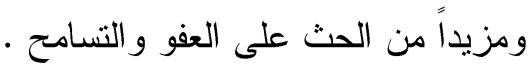
و على هذا الأساس ، ومن ذلك المنطلق ، قدم الإسلام مفهوماً جديداً للإنسـانية تجــاوز

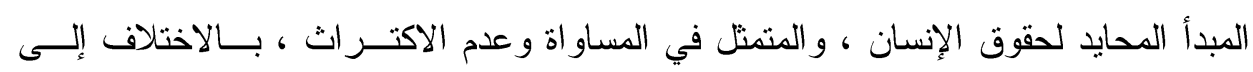

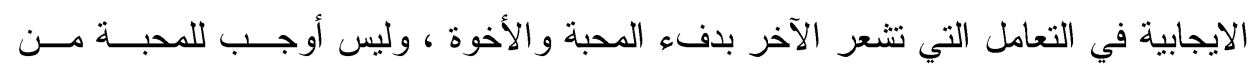


بعض قيم التسامح في الفكر التربوى الاسلامى وكيفية تعزيزها داخل الجامعات المصرية لمواجهة العنف المجتمعى آلمال د/ آمال محمد ابر اهيم المهن

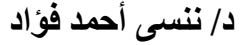

التسامح و السماحة ، فالسلوك الفاضل و التسامح من شأنه أن يقنع الآخر الذي يحمـل نفـس الإعجاب لهذا السلوك ولهذه القيم - قيم التسامح - فالخير يدعو للخير و التسامح يدعو للتسامح

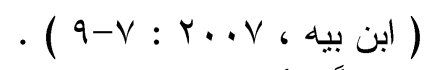

رابعاً : أهم القيم المتضمنة للتسامح في ضوء الته الفكر التربوي الإسلامي هناك الكثير من القيم المتضمنة للتسامح ، وسوف تنتاول الدراسة بعض منها كالآتي :

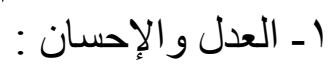

العدل حالة للففس وقوة بها تسوس الغضب و الثهوة ، وتحملها على مقتضى الحكمــة ،

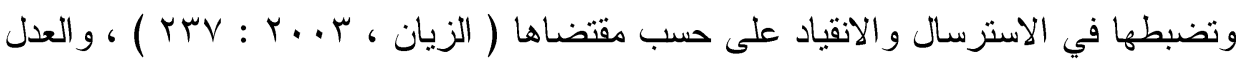

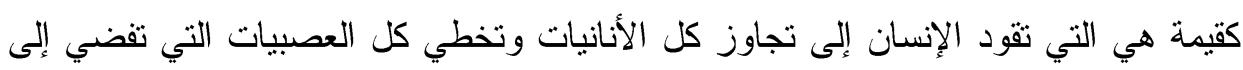

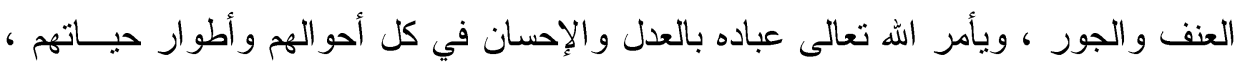

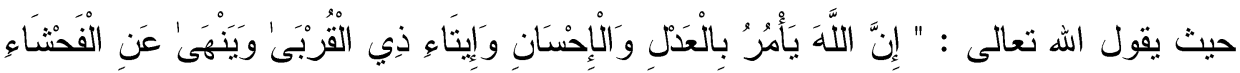

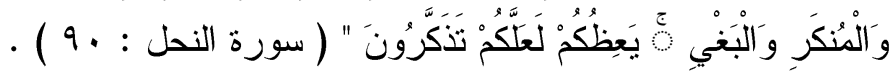

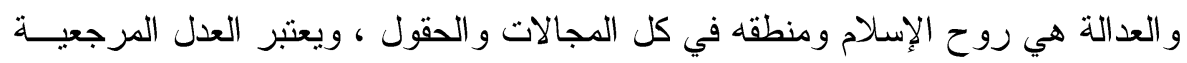

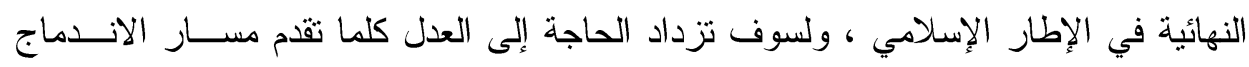

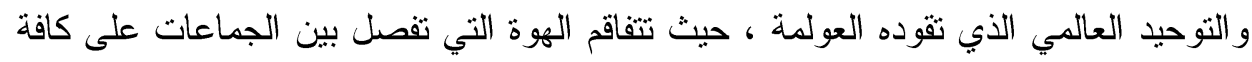

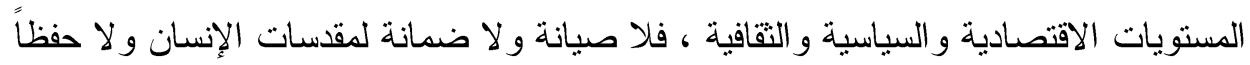

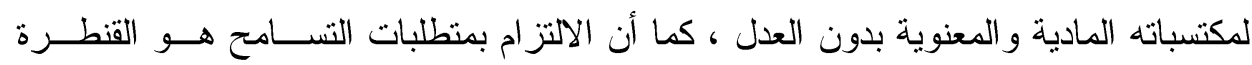

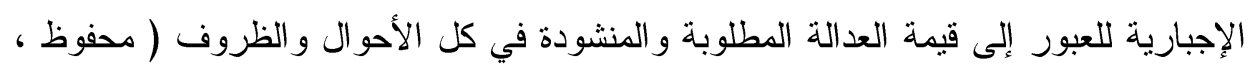
. ( $1 \wedge \varepsilon-1 \wedge \cdot:$ : r. .

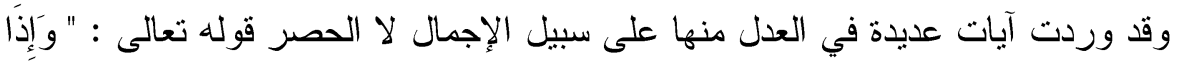

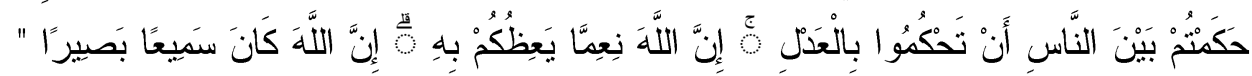

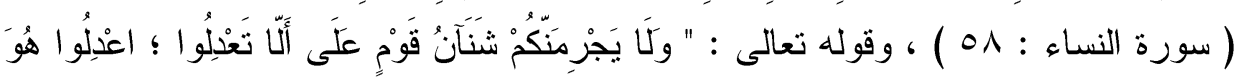

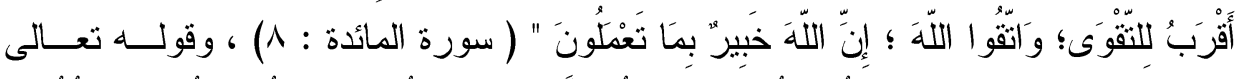

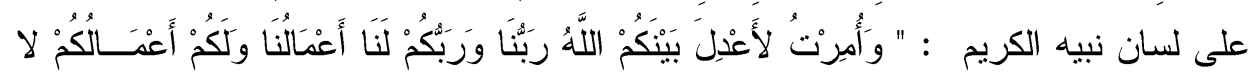

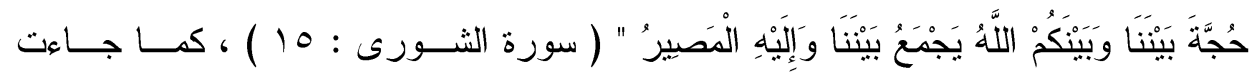

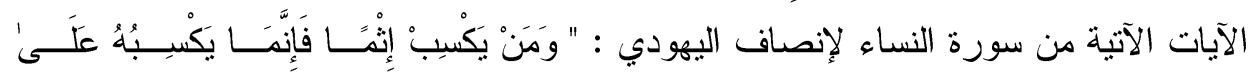

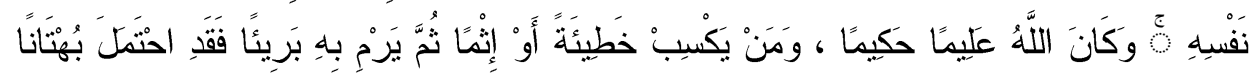




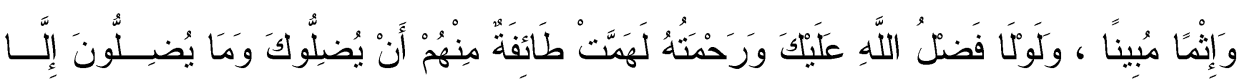

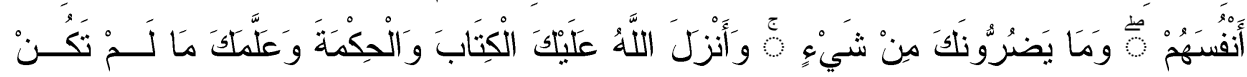

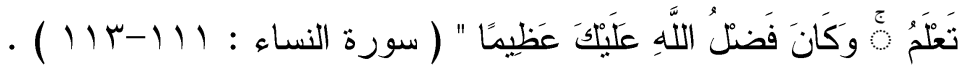

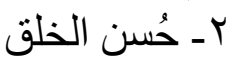
و هو أن يكون الفرد لين الجانب ، طلق الوجه قليل النفور ، طيب الكلمة ، وقد قــال الله

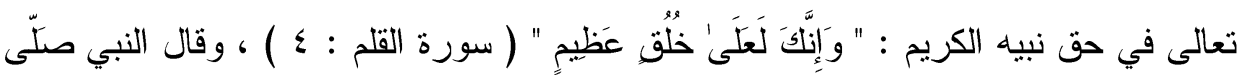

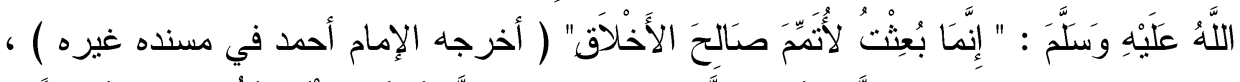

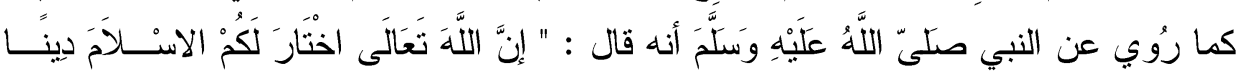

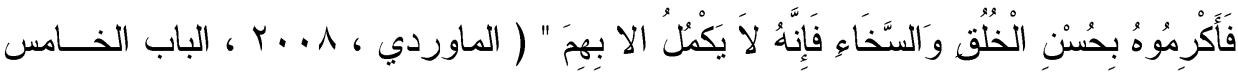

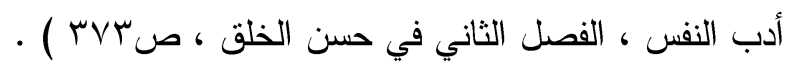
و الخلق هيئة في النفس راسخة ، تصدر عنها الأفعال بسهولة ويسر ، ومن غير حاجـة إلى فكر وروية ، ومن أكثر ما يرجح كفة الحسنات يوم القيامة حســن الخلــق ( قر اعــة ،

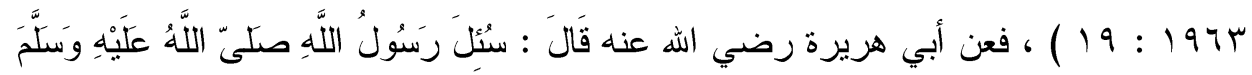

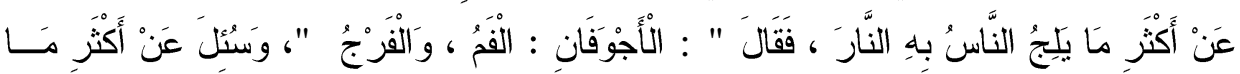

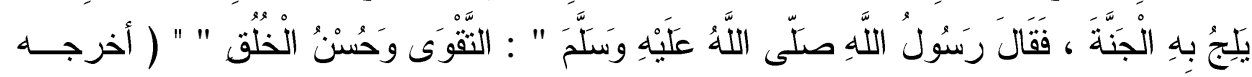

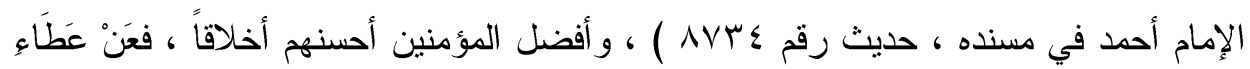

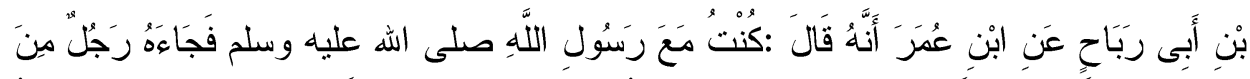

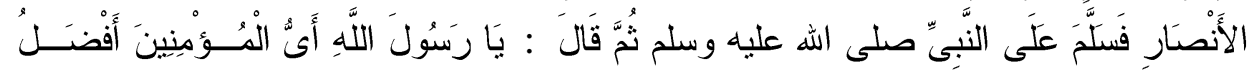

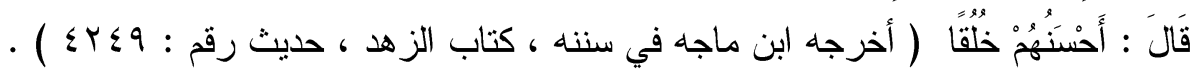
و المتدين الذي يباشر العبادات ، ثم يظل بادي الثر ، كالح الوجه ، قريــب العــدوان ،

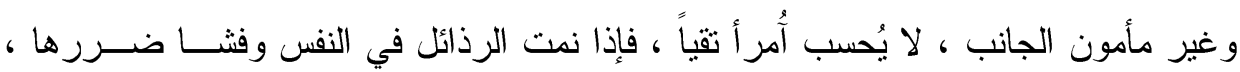
انسلخ صـاحبها من دينه ، كما ينسلخ العريان من ثيابه ، و أصبح ادعاؤه للإيمان زوراً ، فــلا

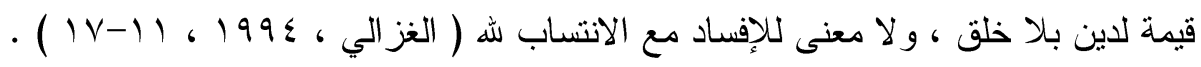

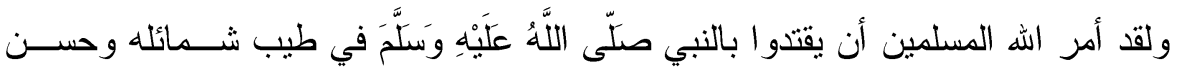

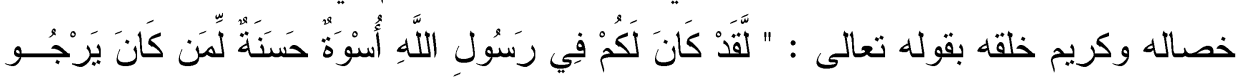

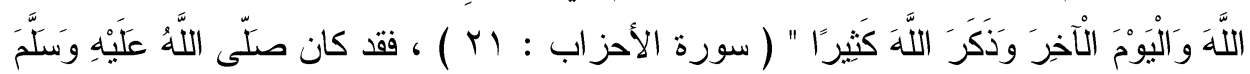
غاية في حسن الخلق ، يؤلف بين أصحابه ، ويكرم كريم كل قوم ، وكان سهل الطبع ، لـين الجانب ، رحيما ليس بفظ و لا غليظ ، و لا فحاش و لا عتاب ، وكان يجيب دعوة العبــد كمــا

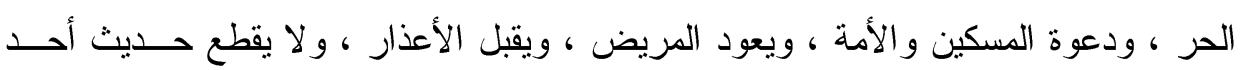


بعض قيم التسامح في الفكر التربوى الاسلامى وكيفية تعزيزها داخل الجامعات المصرية لمواجهة العنف المجتمعى آلمال د/ آمال محمد ابر اهيم المهن

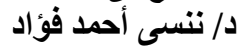

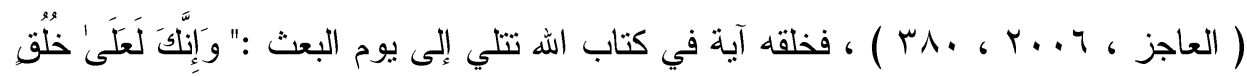

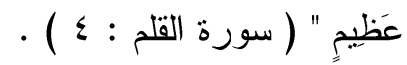
فما أجدر بنا أن نهتدي بسيد الخلق ، ونقتفي أثره ، ونتخلق بخلقه السمح الكريم ، فيتعزز

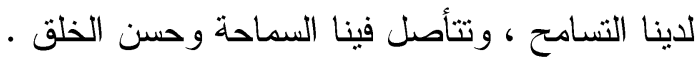

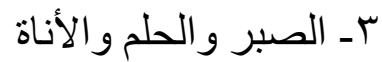

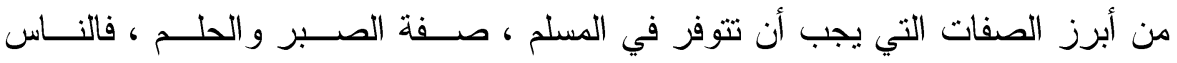

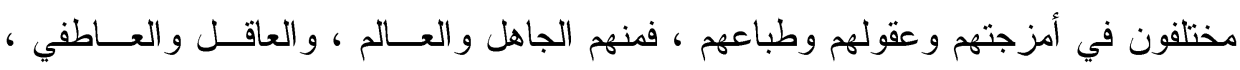

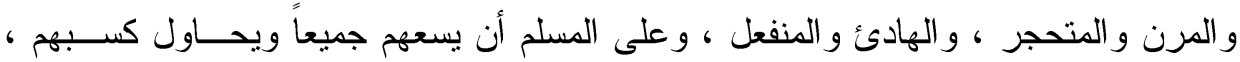

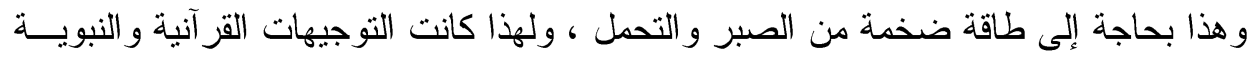

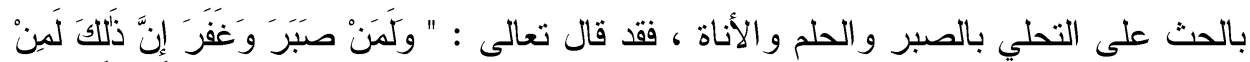

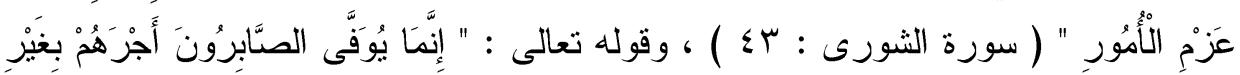

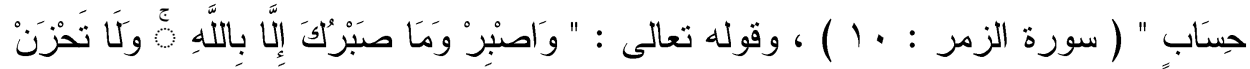

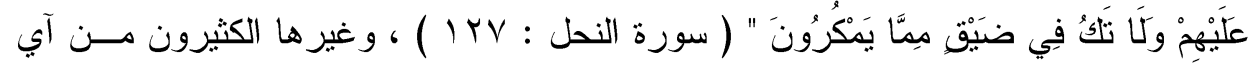

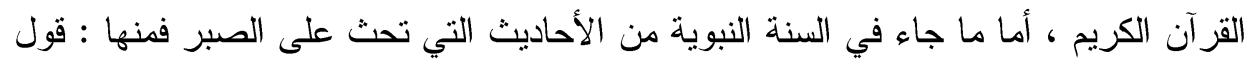

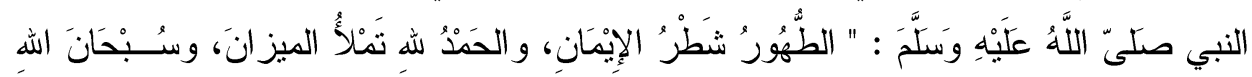

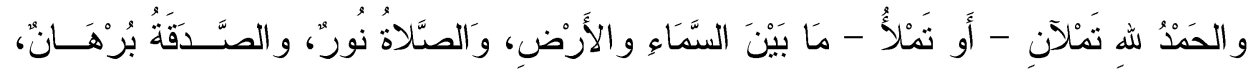

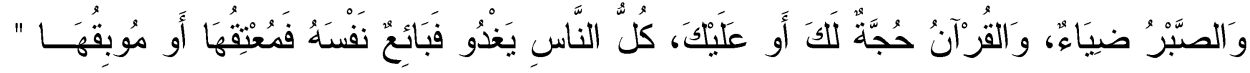

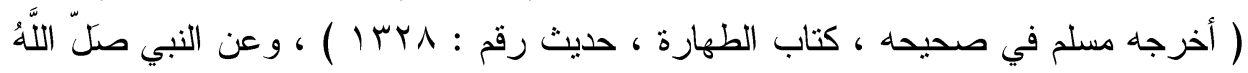

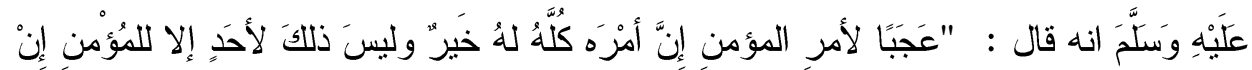

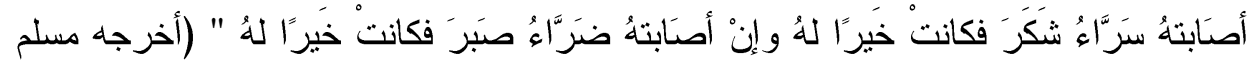

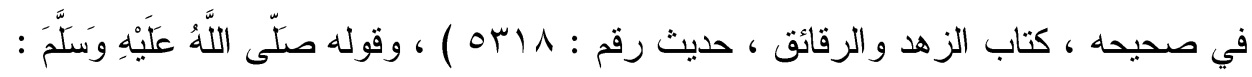

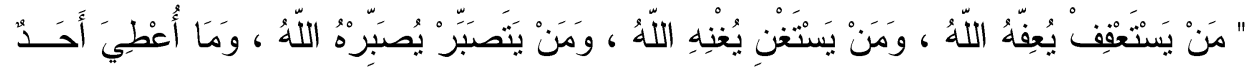

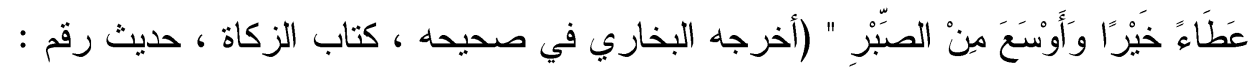

(I) rVT

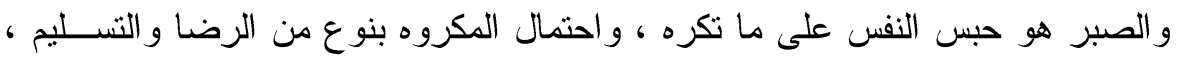

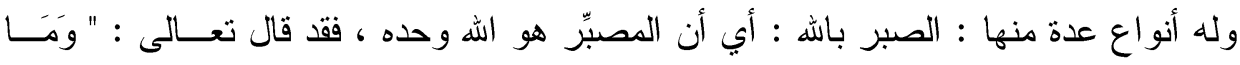

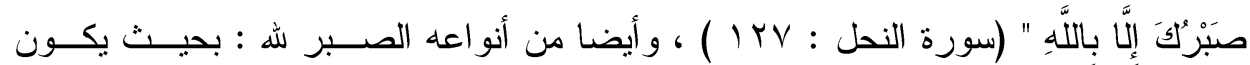

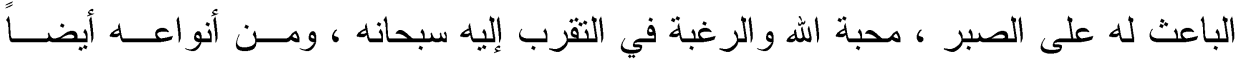


بعض قيم التسامح في الفكر التربوى الاسلامى وكيفية تعزيزها داخل الجامعات المصرية لمواجهة العنف المجتمعى

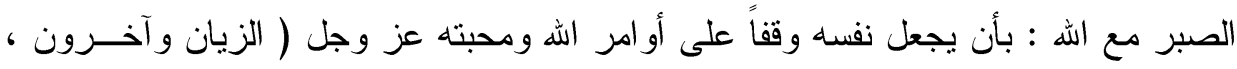

$$
\text { . }(r \leq r-r \leq): r \cdot r
$$

وتتمثل قمة الأدب في الصبر في احتمال الأذى ، و هذه من طبقات النبيــين و الصـــيقين

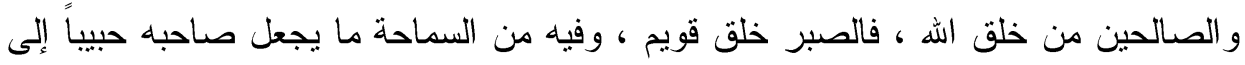

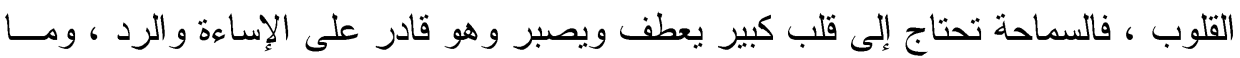

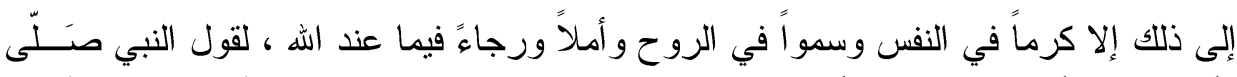

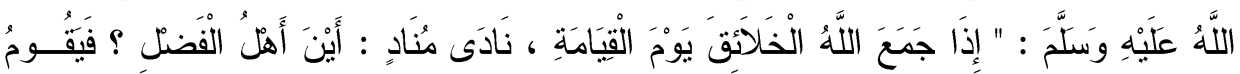

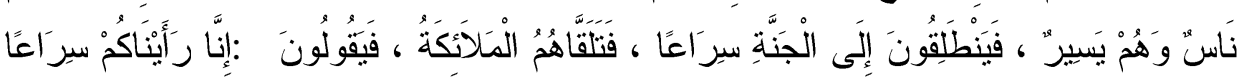

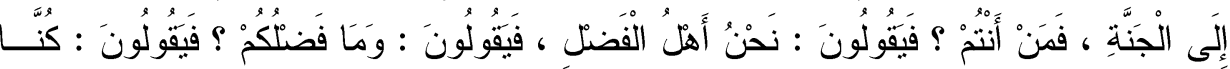

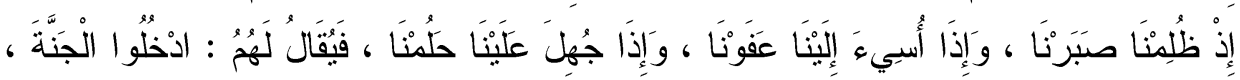

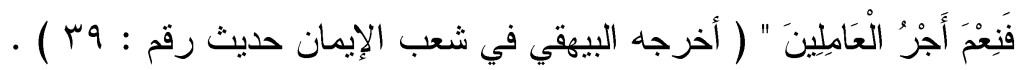

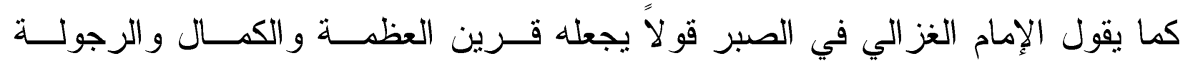

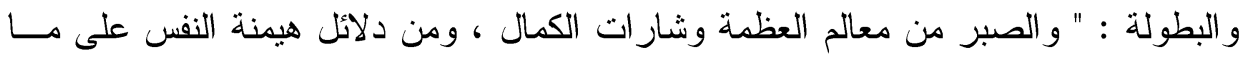

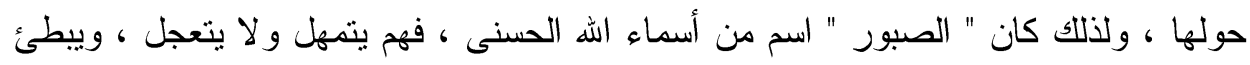

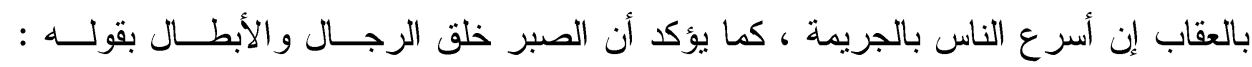

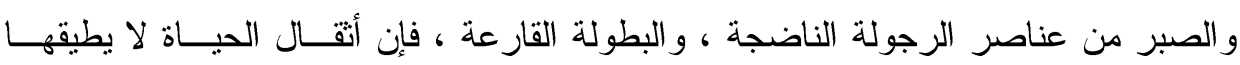

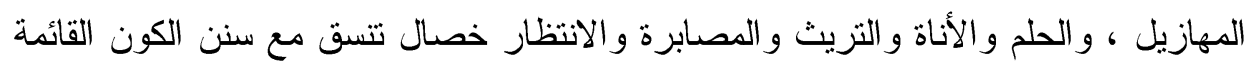

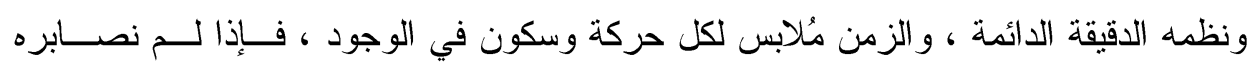

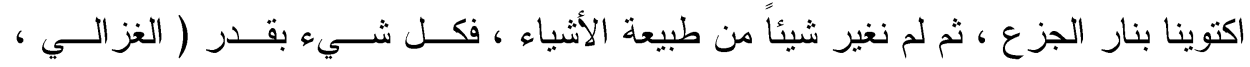
· (1 (1)-1rv: 199 فأحرى بأمة الإسلام أن تتصف بالصبر لما له من تأثير ايجابي على نفس المسلم وعلى

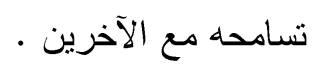

ع ـ العفو و الصفح وكظم الغيظ

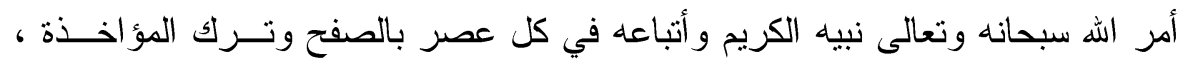

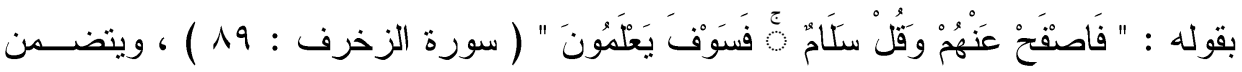

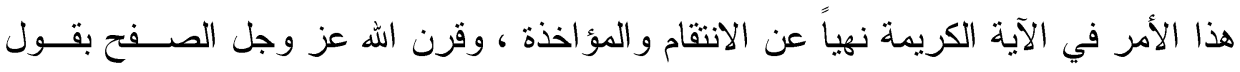

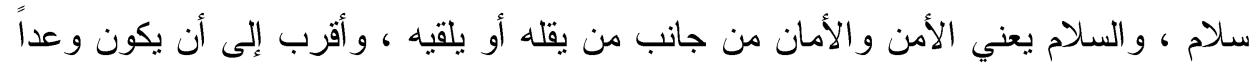

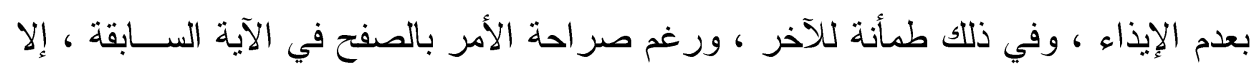


بعض قيم التسامح في الفكر التربوى الاسلامى وكيفية تعزيزها داخل الجامعات المصرية لمواجهة العنف المجتمعى آلمال د/ آمال محمد ابر اهيم المهن

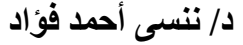

أنه سبحانه وتعالى أر اد تأكيد هذا الأمر وزيادته جمالاً وبهاءً ، فقد قال تعــالى : " فَاصْــفحَح

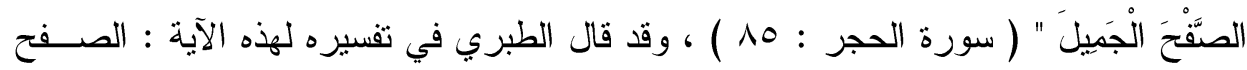

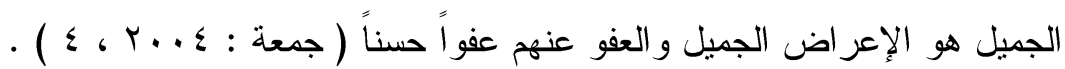

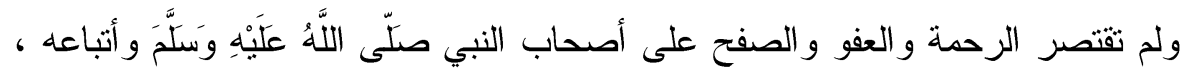

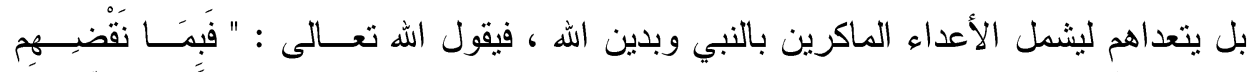

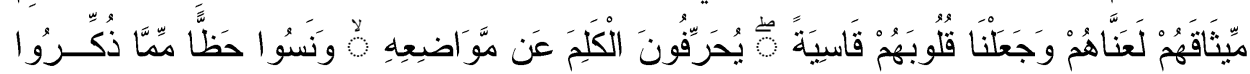

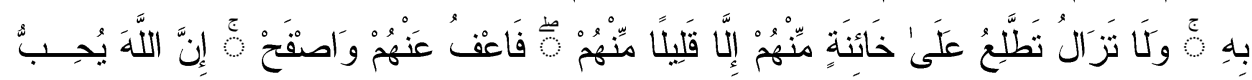

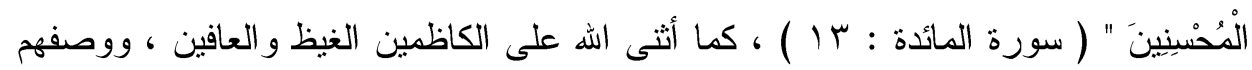

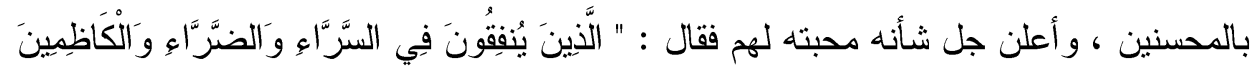

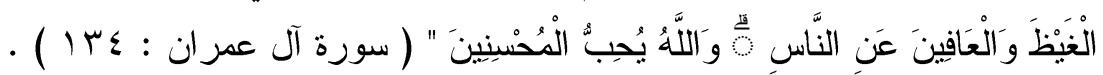

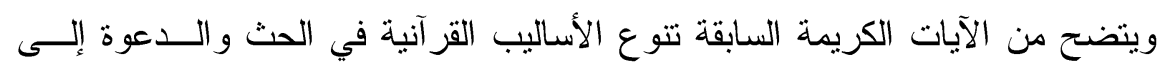

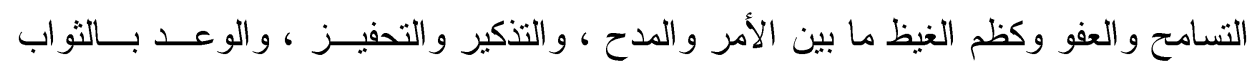

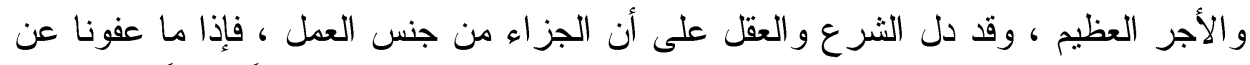

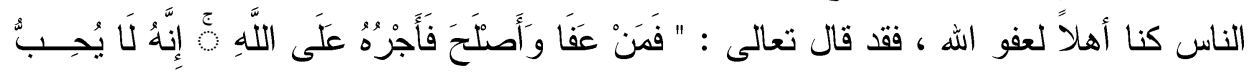

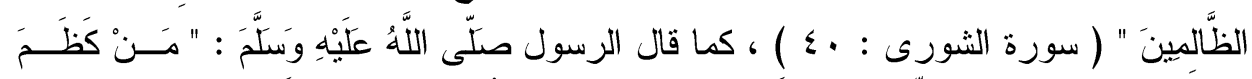

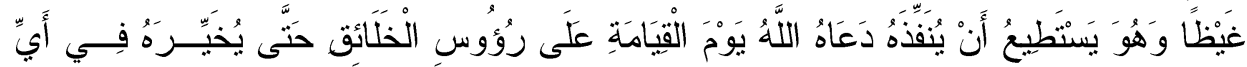

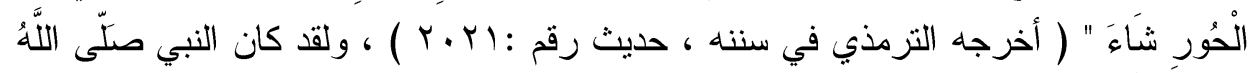

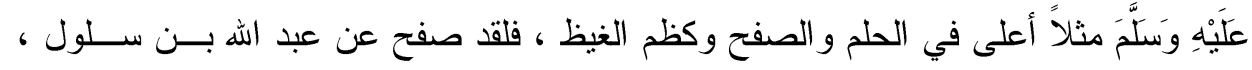

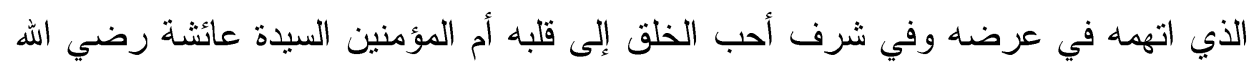

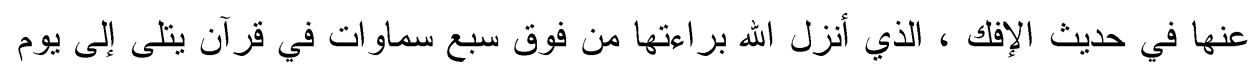

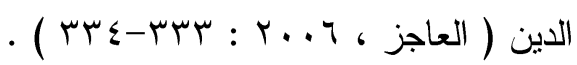

فالعافون عن الناس الذين يسامحون عمن أساء إليهم مع القدرة على الاعتداء ، أولئك لهم الهم منزلة في ضبط النفس ، تدل على سعة العقل ورحابة الفكر وقوة الإرادة .

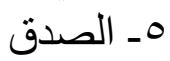

يعتبر الصدق دعامة خُلق المسلم ، وصبغته التي تصبغ سلوكه قو لاً وفعـلاً ، و الكـــب

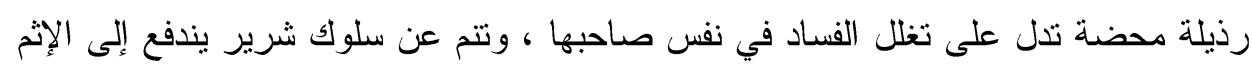

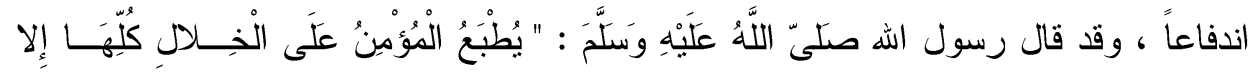

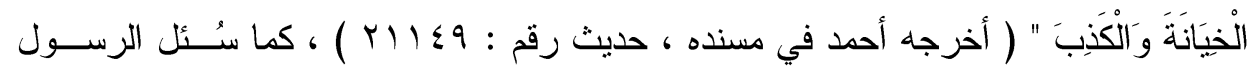

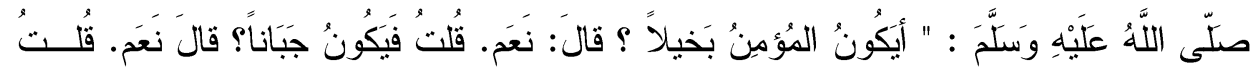




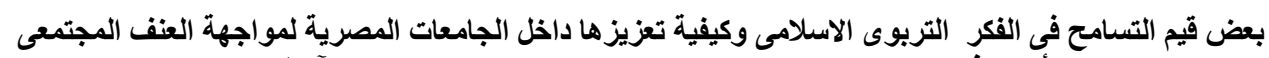
د/ آمال محمد ابر اهيم المهن

د/ تنسى أحمد فؤاد الفئر

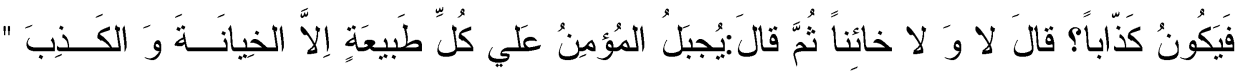

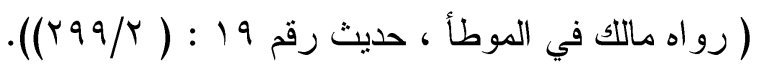

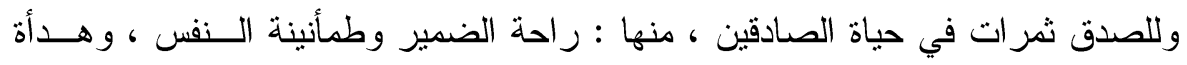

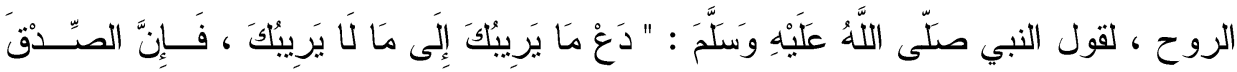

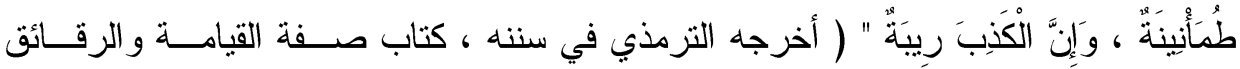

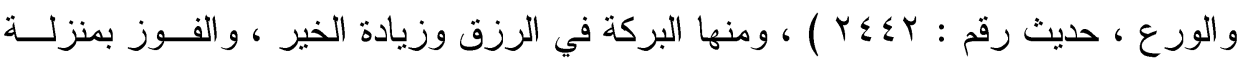

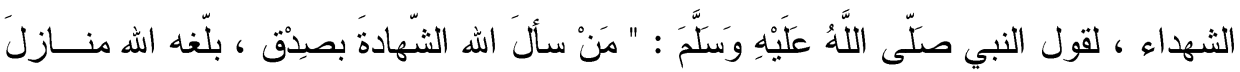

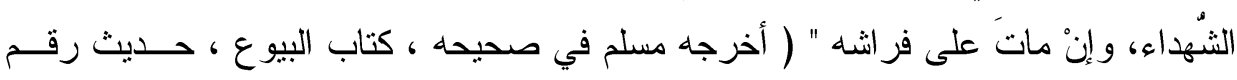

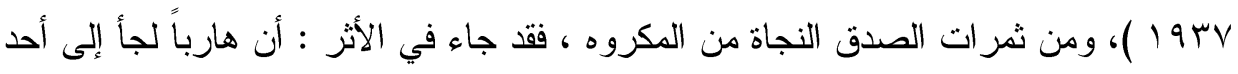

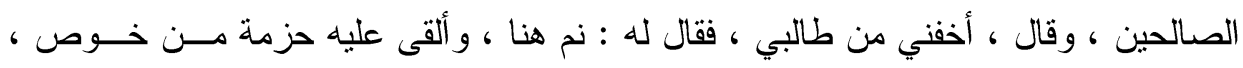

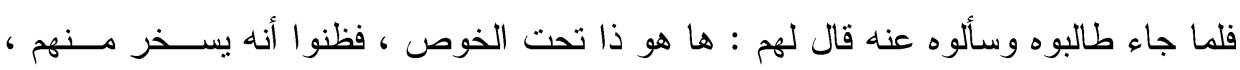

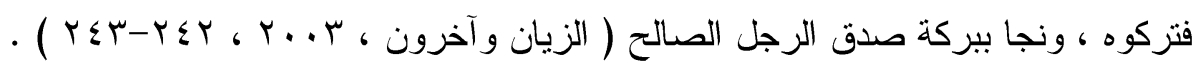

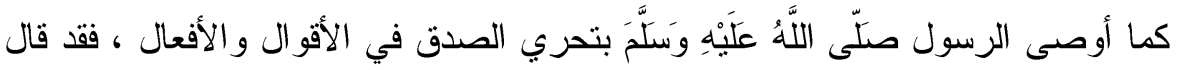

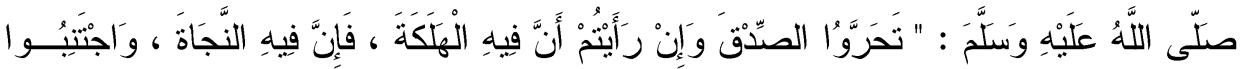

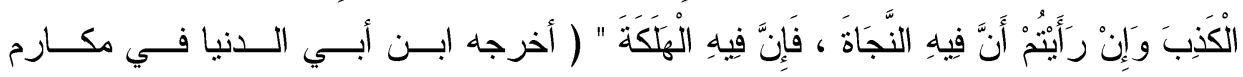

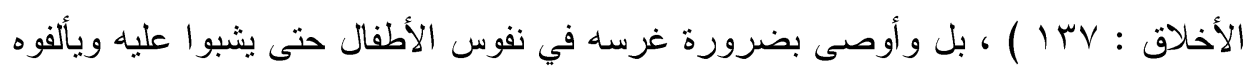

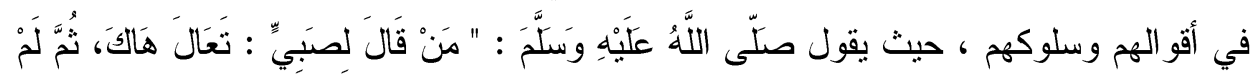

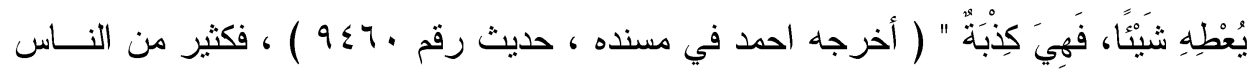

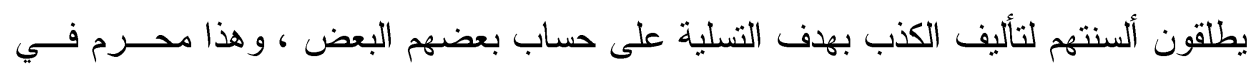

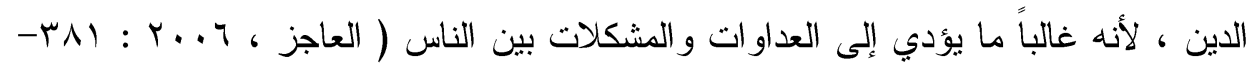
. (rNT وعلاقة الصدق بالتسامح علاقة وثيقة وطيدة ، فبقدر ما يعم الصدق بين النــاس فــولاً وفعلاً ، بقدر مل يهيأ المناخ للتسامح و التجاوز عن الأخطاء . 7- الرحمة

هي صفة لها كمال وجلال تجعل المرء برق لآلام الناس ، ويسعى لمساعدتهم و التخفيف

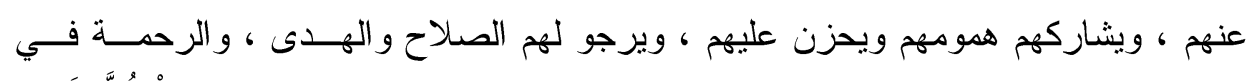

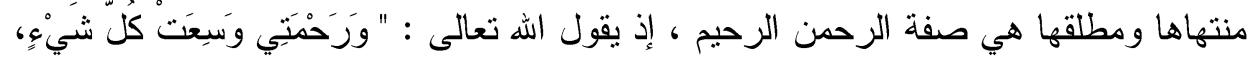

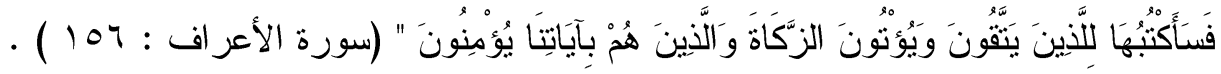




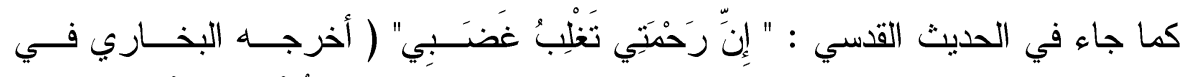

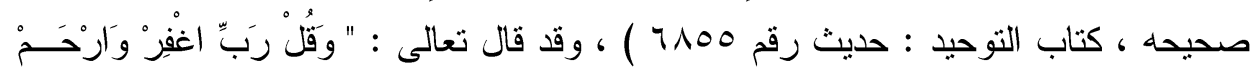

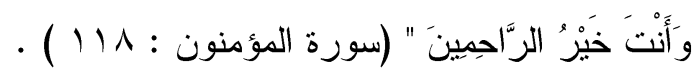

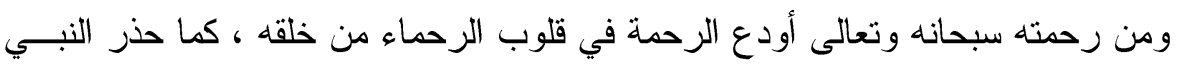

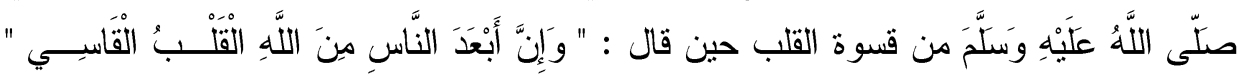

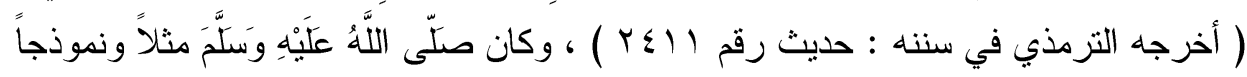

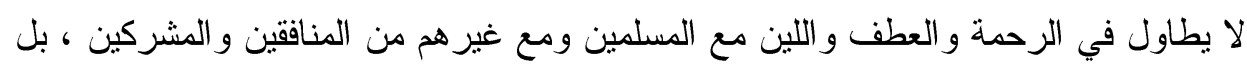

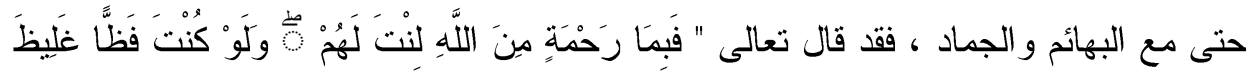

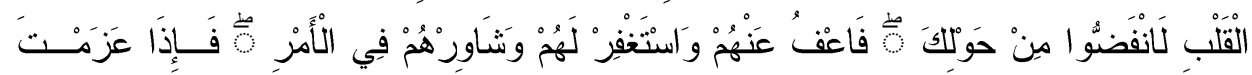

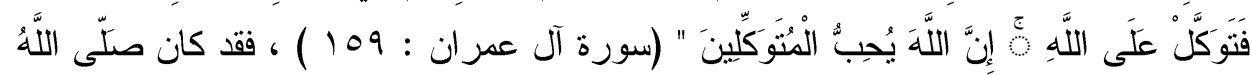

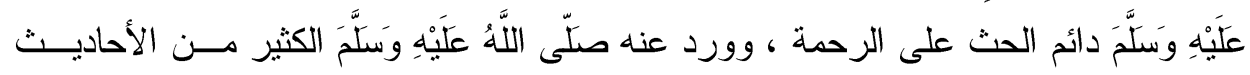

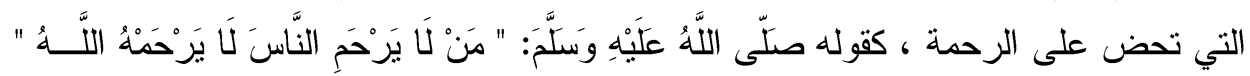

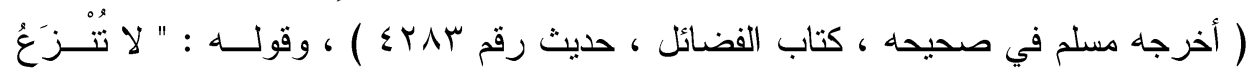

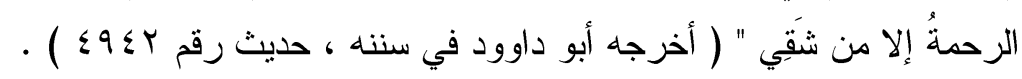

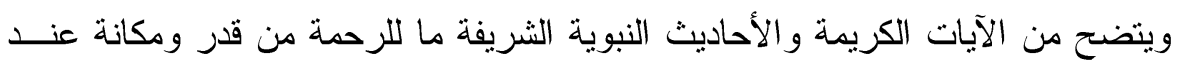

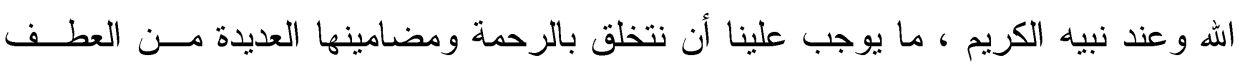

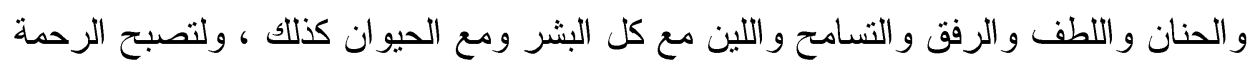
أصلاً في سلوكنا ومنطلقاً في تعاملنا و إحساسنا بالآخرين .

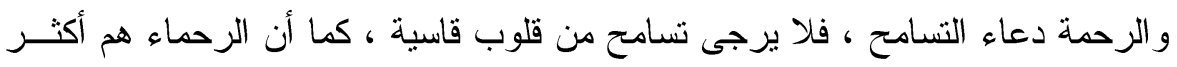

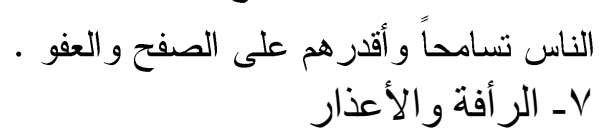
من قيم التسامح الر أفة والأعذار ، فالر أفة خلق إسلامي و إنساني رفيع يؤلف بين القلوب

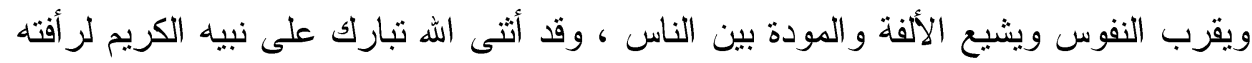

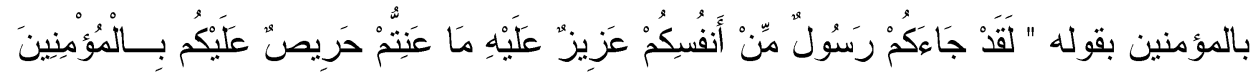

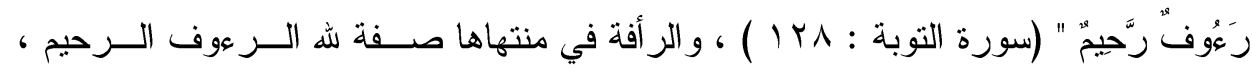

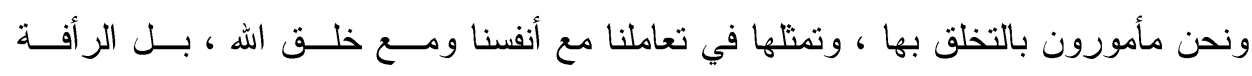

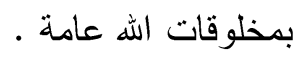

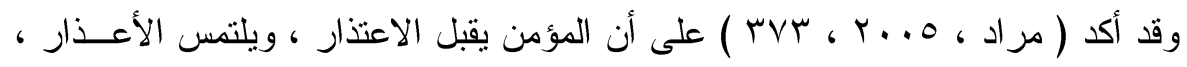

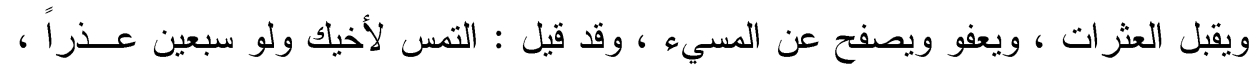




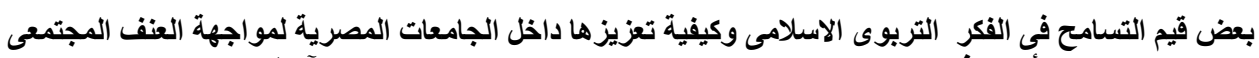
د/ آمال محمد ابر اهيم المهن

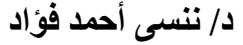

فان لم تجد فابحث له عن عذر ، و إذا كان التماس الأعذار للناس محموداً ، فان قبول اعتذار

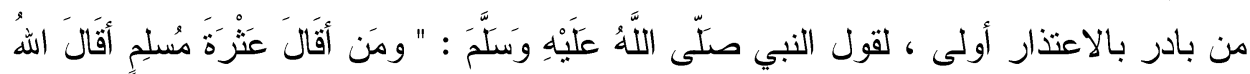

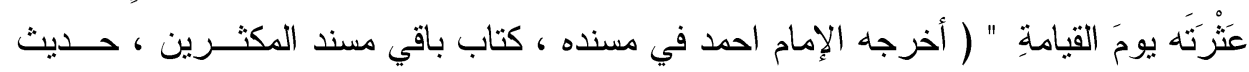

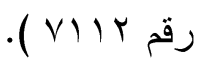

ومن لا يقبل الاعتذار غير منصف لنفسه و لا لغيره ، فلا يأمن أحسـنـا هفــوة أو خطــأ

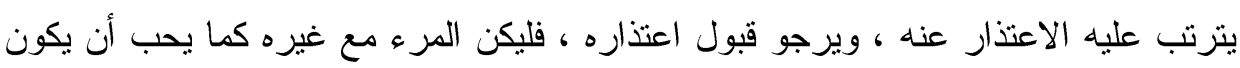

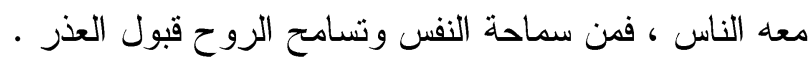
A- م- الإيثار

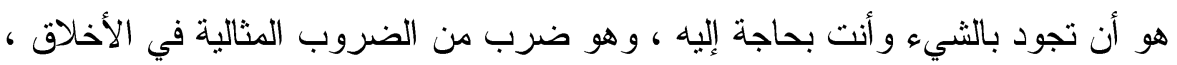

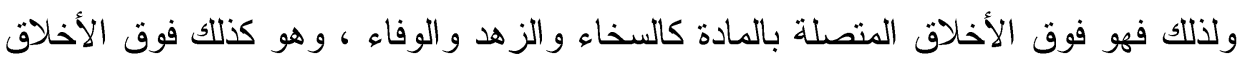

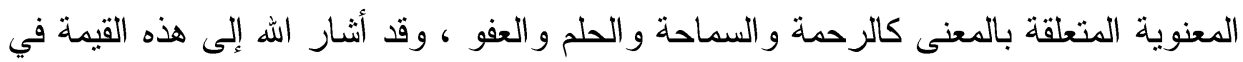

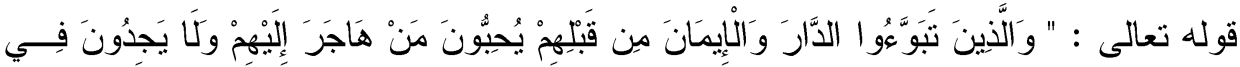

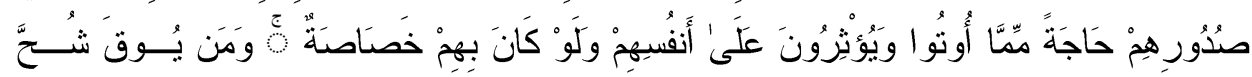

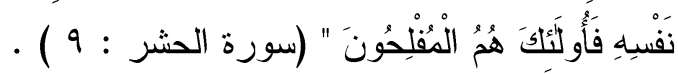

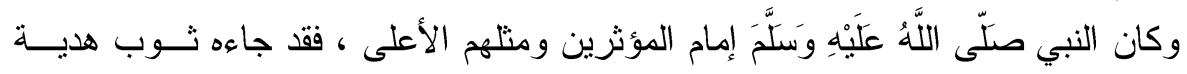

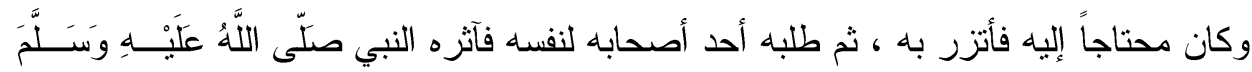

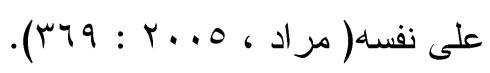

وغريزة حب النفس أصيلة في بني آدم ، ولكن الأخوة الإنسانية التي جعلهــا الإســلام نظاماً عادلاً تصان به الحقوق و الواجبات ، هذه الأخوة تهذب غريزة حب النفس وتقي المسلم

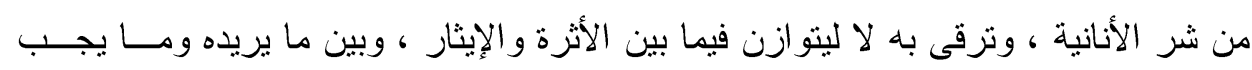

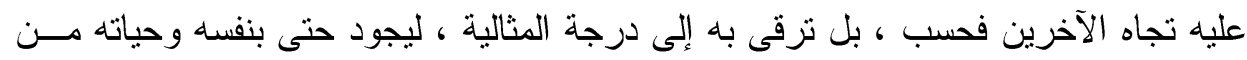

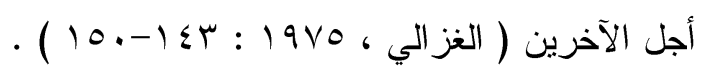

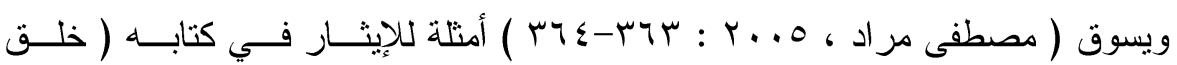

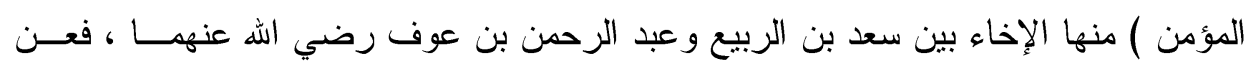

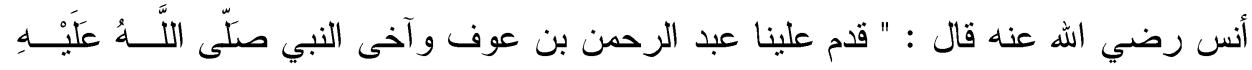

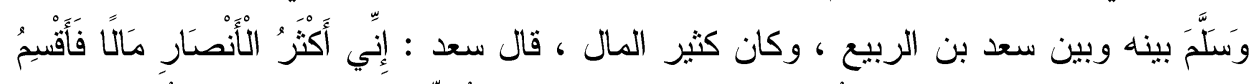

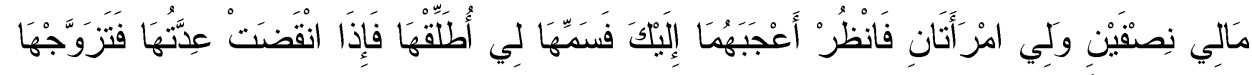

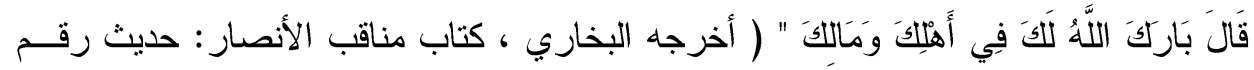
. 


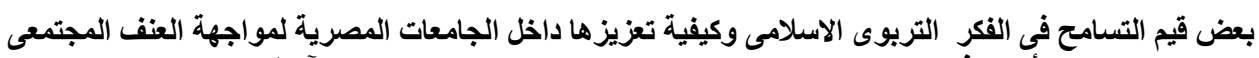
د/ آمال محمد ابر اهيم المهن

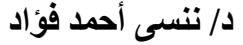

بن أبي ثابت رضي الله عنه أن الحارث بن هشام ، و عكرمة بن أبي جهل ، وعياش بن أبي

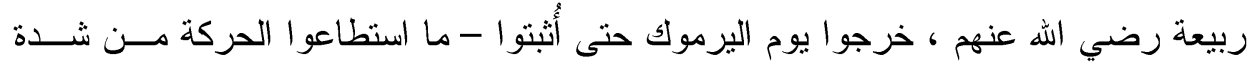

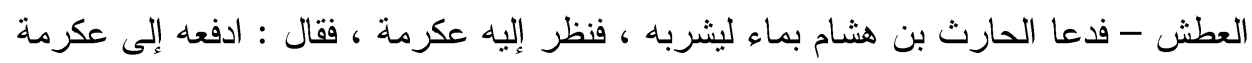

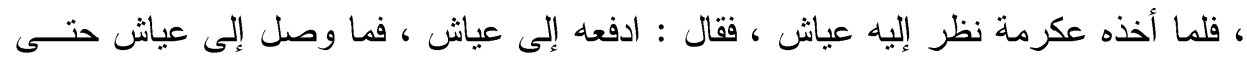

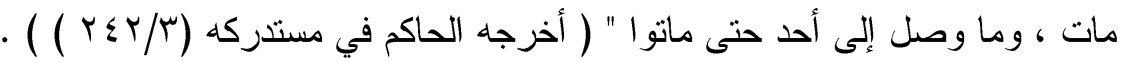
9- الإخاء و الاتحاد

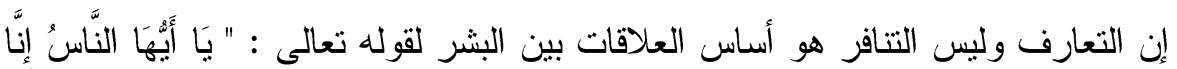

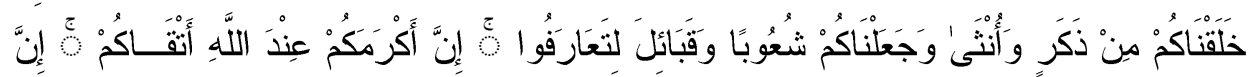

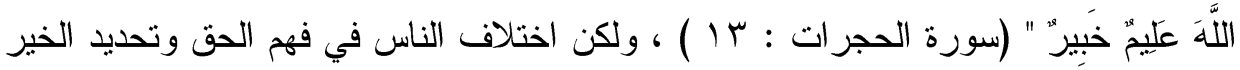

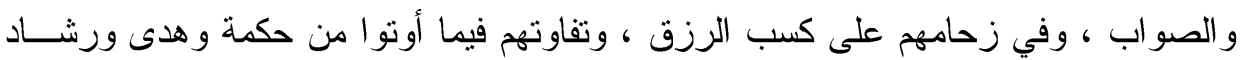

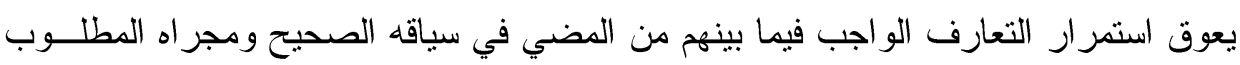

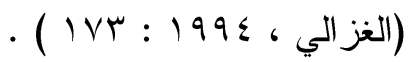

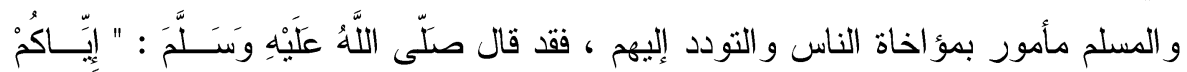

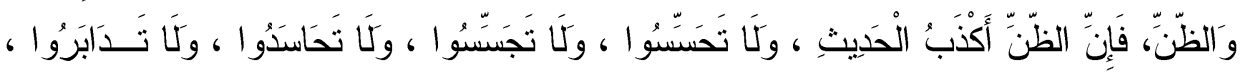

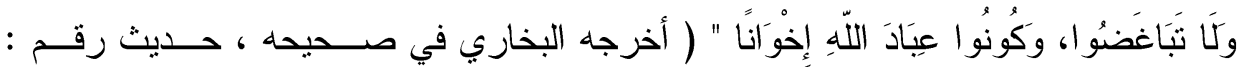

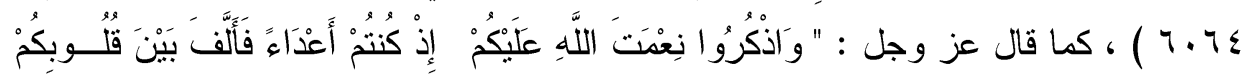

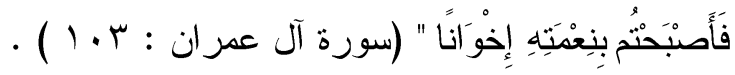

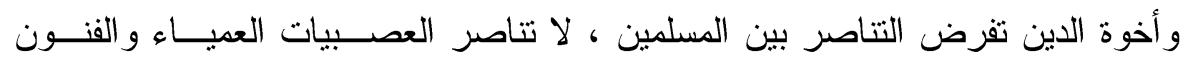

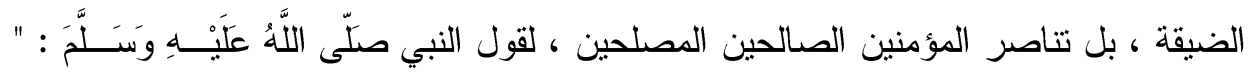

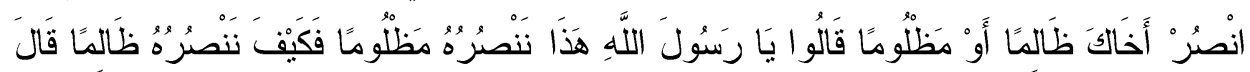

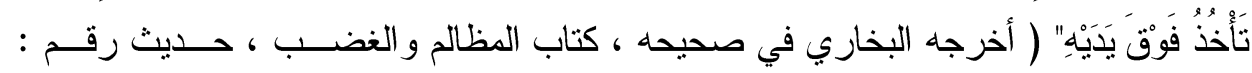

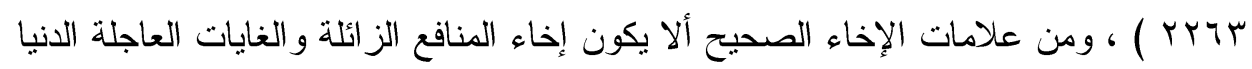

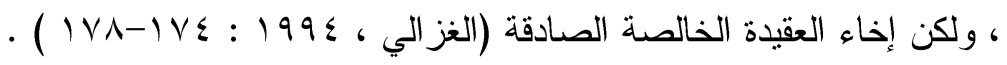

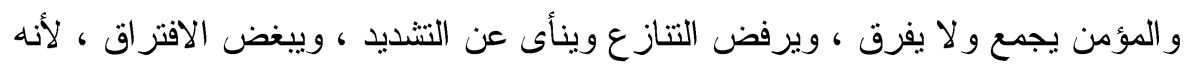

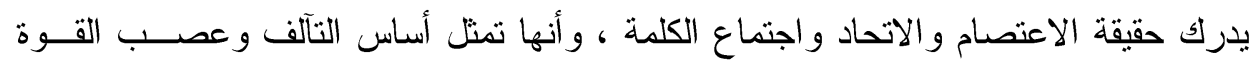

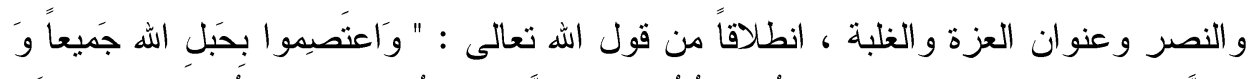

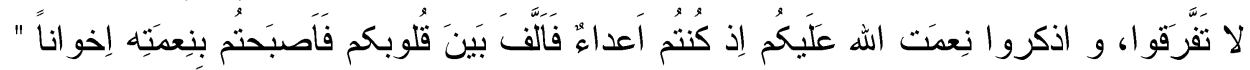

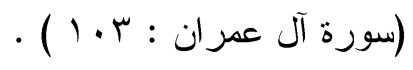




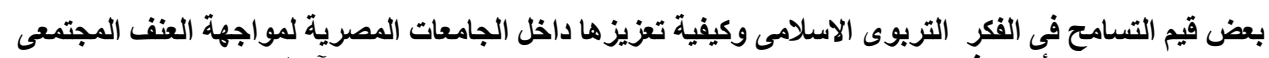
د/ آمال محمد ابر اهيم المنف المجنم

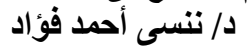

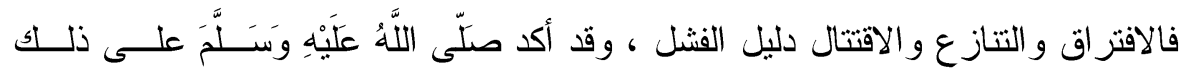

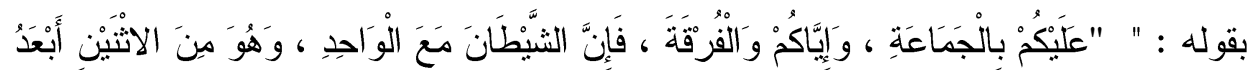

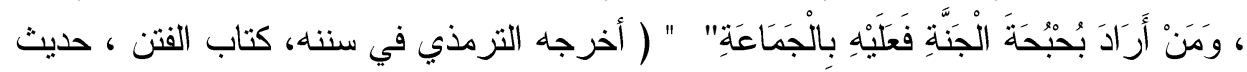

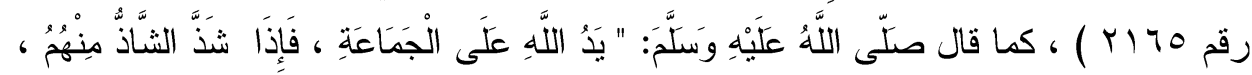

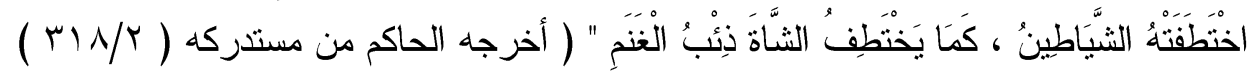

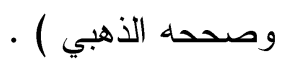

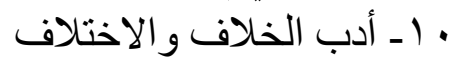

الاختلاف هو التباين في الرأي و المغايرة في الطرح وقد ورد فعل الاختلاف كثيراً فــي

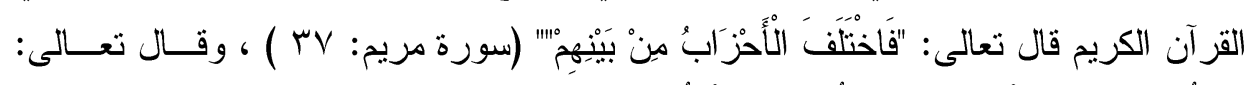

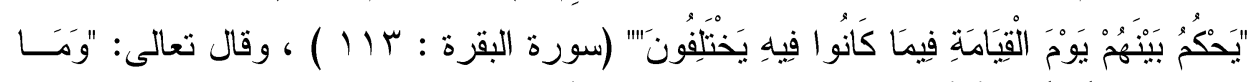

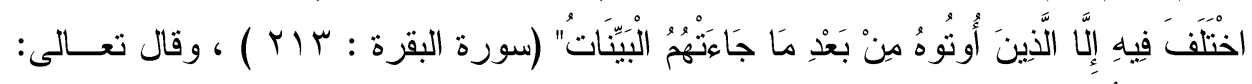

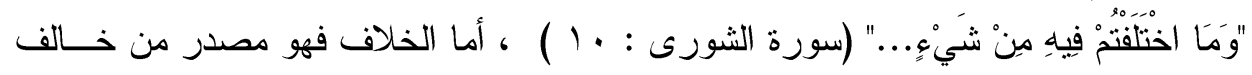

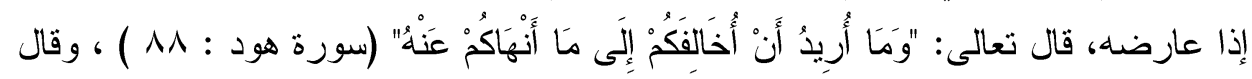

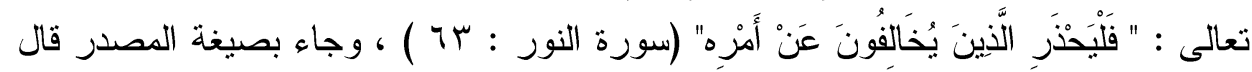

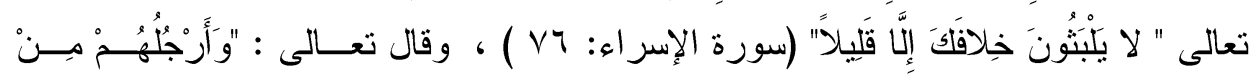

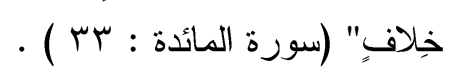

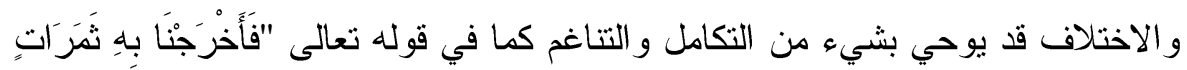

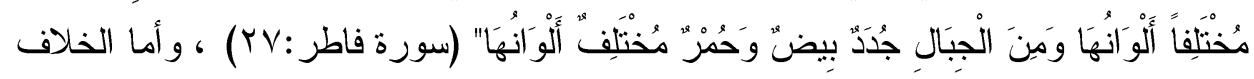

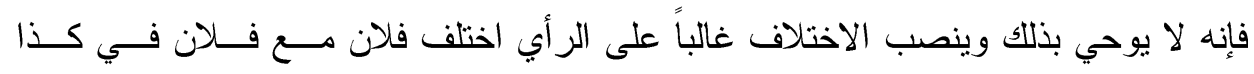
و الخلاف ينصب على الثخص. والاختلاف ظاهرة لا يمكن تحاثيها باعتبار ها مظهراً من مظاهر الإرادة الإنسانية التي قد تؤدي إلى وقوع الاختلاف و التفاوت في الرأي . وقد انتبه لذلك العلامة ابن القيم عندما يقول: "وقوع الاختلاف بوت بين الناس أمر ضروري

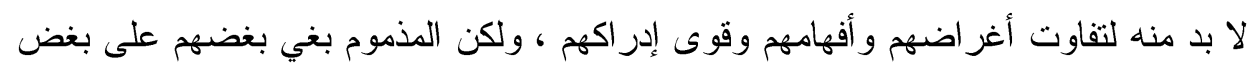

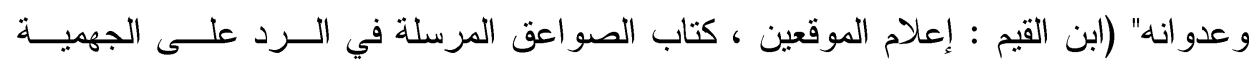
و المعطلة ( / / / ( ) ) ، فإن الثقاق يمكن تفاديه بالحوار الذي من شأنه أن يقدم البدائل العديدة لتجنيب مأزق الاصطدام في زاوية الثقاق.

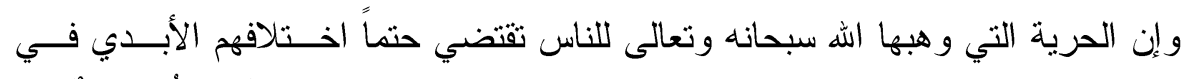

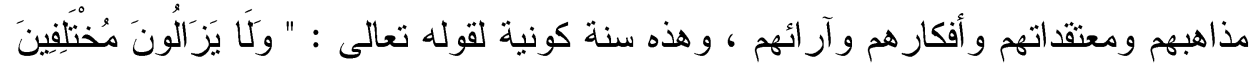


بعض قيم التسامح في الفكر التربوى الاسلامى وكيفية تعزيزها داخل الجامعات المصرية لمواجهة العنف المجتمعى

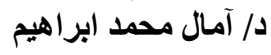

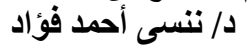

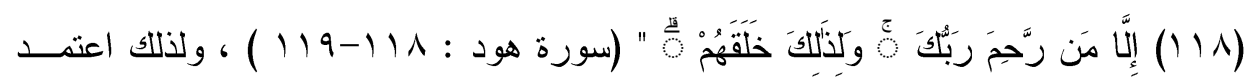

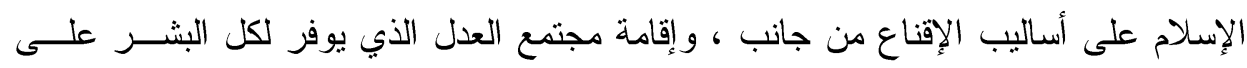

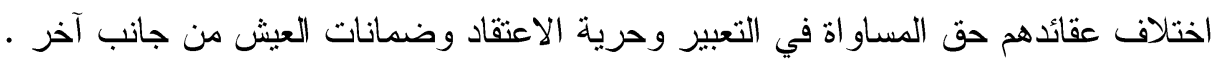

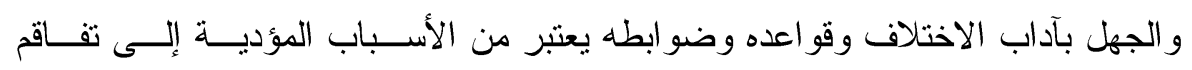

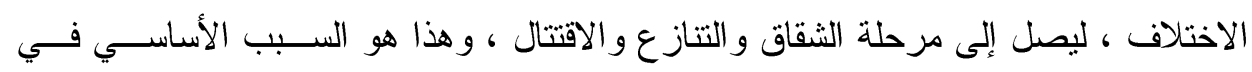

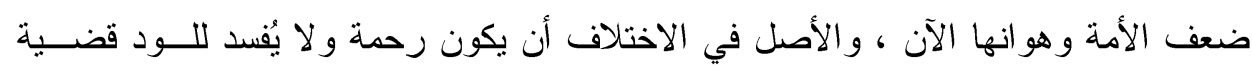

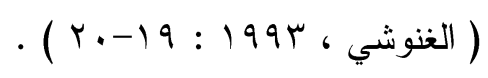

ولقد حظيت مسألة الاختلاف باهتمام بالغ في الآونة الأخيـرة ، و لالـــيما مــع تتـامي

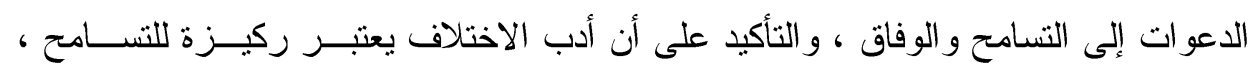

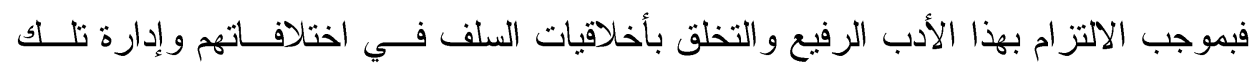

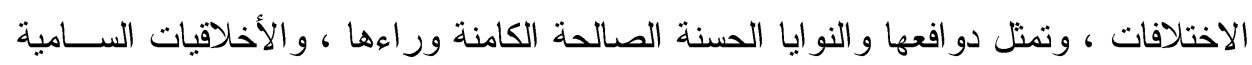

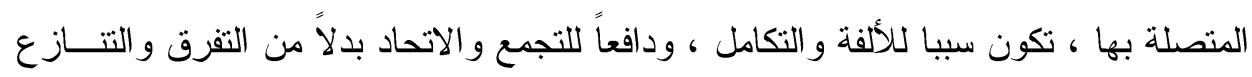
و الثقاق . خامساً : العنف المجتمعي ( ) - ماهية العنف المجتمعي.

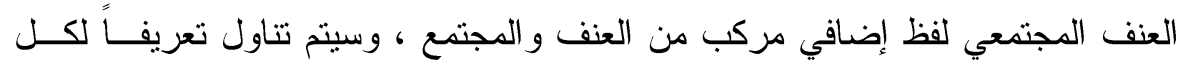
منهما على حده لغة و اصطلاحاً :

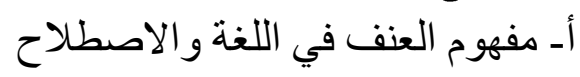

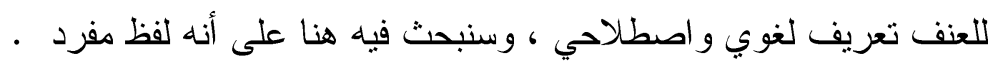
تعريف العنف لغة:

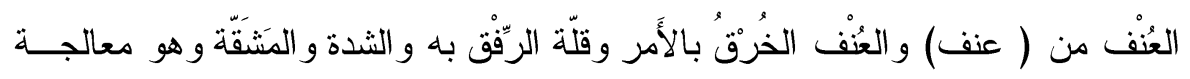

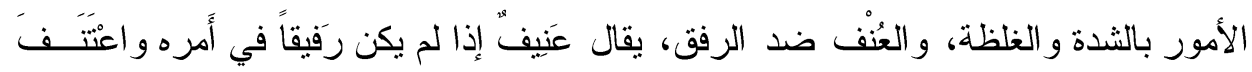

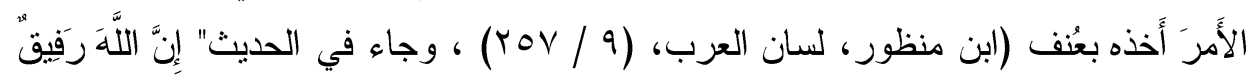

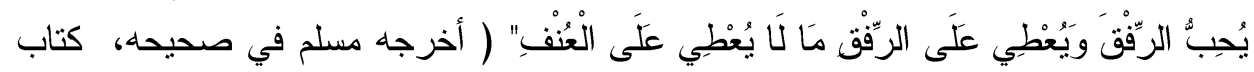

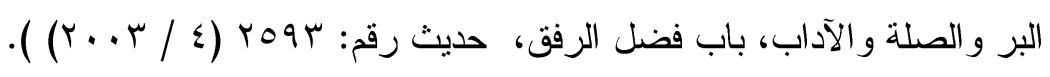
العنف في الاصطلاح ،عرف بأكثر من تعريف:

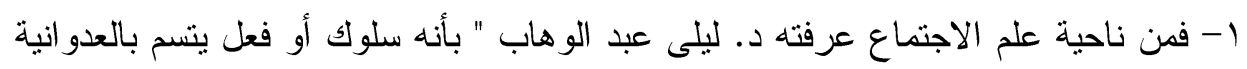

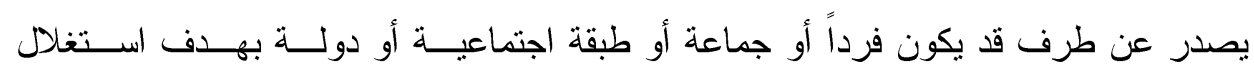

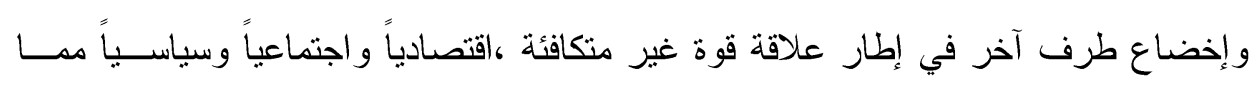


بعض قيم التسامح في الفكر التربوى الاسلامى وكيفية تعزيزها داخل الجامعات المصرية لمواجهة العنف المجتمعى آمال

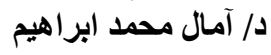

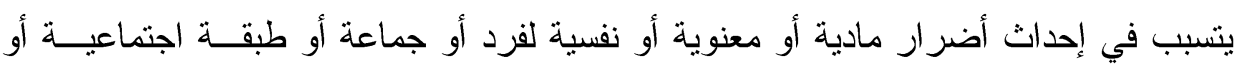

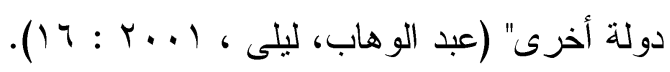

r- وعرفه بعض علماء النفس على أنه" نمط من أنماط السلوك ينتج عن حالة : إحباط،ويكون

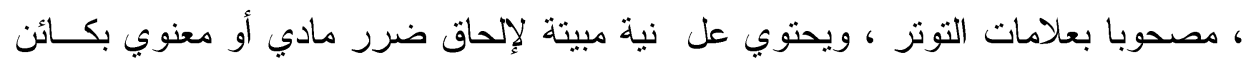

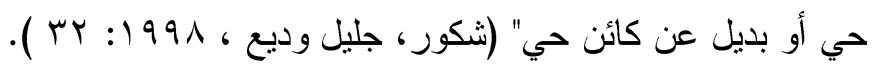

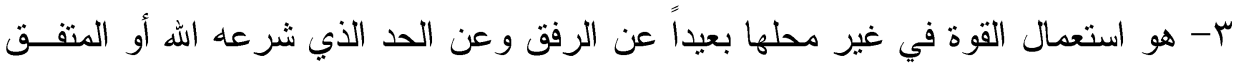

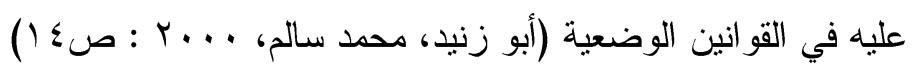

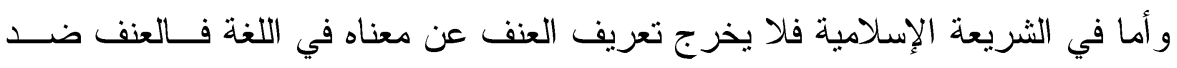

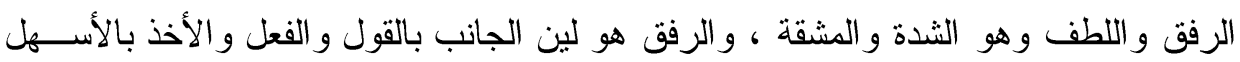

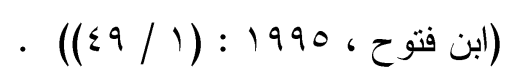

إذن العنف هو الضرر بأنو اعه لمن لا يستحقه شرعاً.

$$
\text { مفهوم المجتمع لغة و اصطلاحاً }
$$

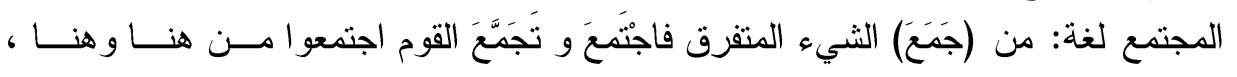

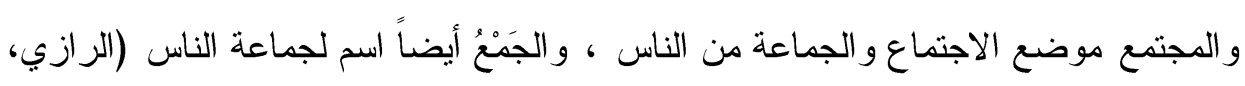

$$
\text { المجتمع في الاصطلاح: : (1) / (1) ). }
$$

عُرِّت بأنه" مجموعة منظمة من الناس يعيشون سوياً نربط أفر ادهم مجموعة مشتركة من

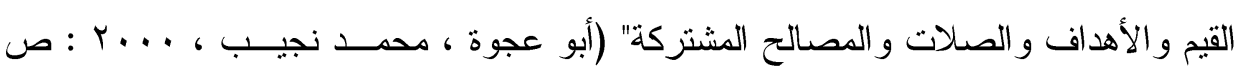

ويُعرَّت المجتمع الإسلامي بأنه" المجتمع الملتزم بتعاليم الله وشرعة و المطبـق لحــدوده

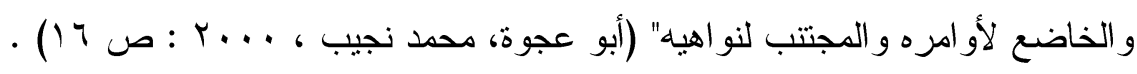

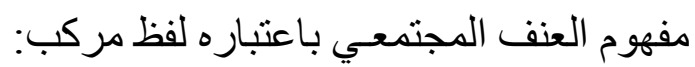

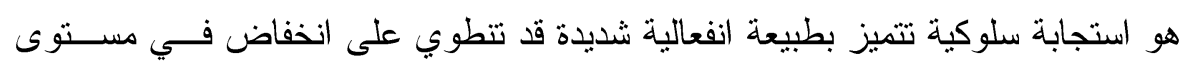

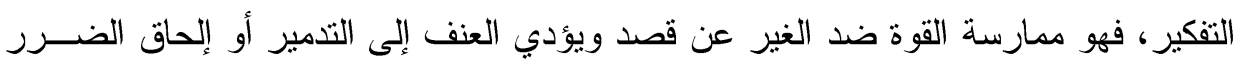
المادي وغير المادي بالنفس و الغير.

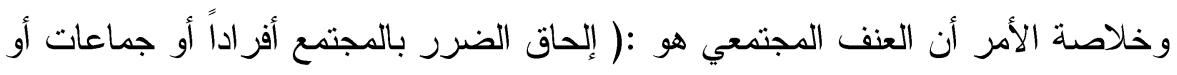
مؤسسات، مسلمين و أهل كتاب و أهل أمان بدون وجه حق مخالفا للشريعة بأية وسيلة مؤذية) 
بعض قيم التسامح في الفكر التربوى الاسلامى وكيفية تعزيزها داخل الجامعات المصرية لمواجهة العنف المجتمعى آمال

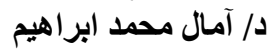

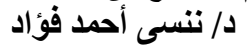

\section{Y ( ب) - أشكال العنف المجتمعي}

لمعرفة ماهية العنف المجتمعي لابد من التعرف على أنثكاله ، فالعنف المجتمعي له أثــكال

عدة منها:

$$
\begin{aligned}
& \text { العنف الأسري. } \\
& \text { العنف ضد الأقارب و الجيران. } \\
& \text { العنف في التعليم. } \\
& \text { العنف ضد الحيو انات و الأشجار و الجمادات. } \\
& \text { العنف العشائري . } \\
& \text { العنف الديني. } \\
& \text { أـ العنف الأسري }
\end{aligned}
$$

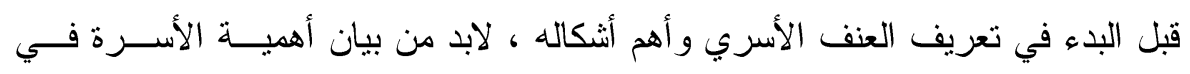

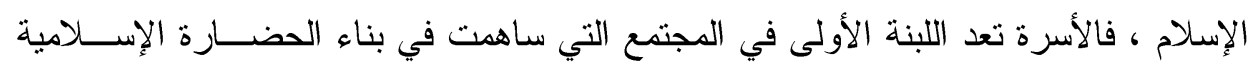

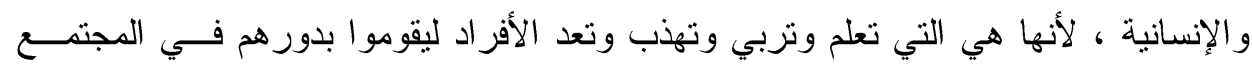

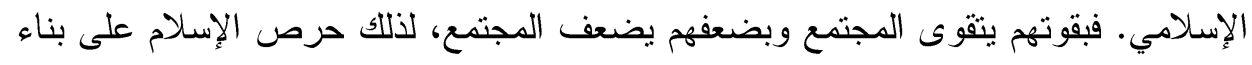

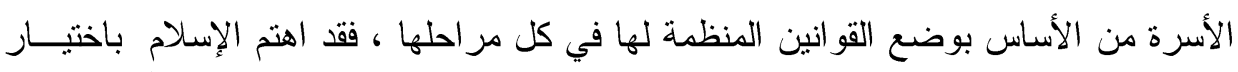

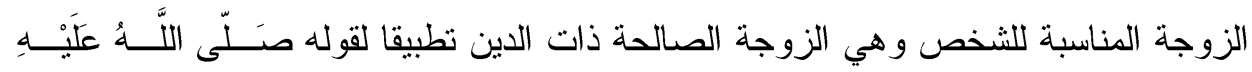

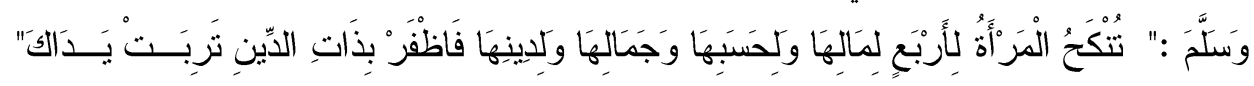

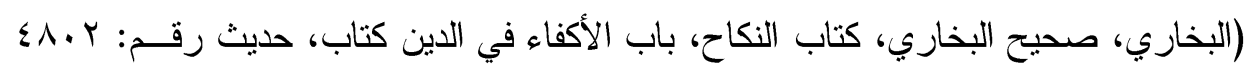

$$
.(1901 / 0)
$$

وقال الصنعاني في سبل السلام" ودل الحديث على أن مصاحبة أهل الدين في كل شيء

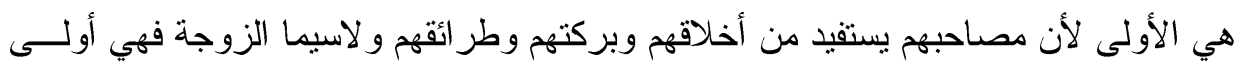

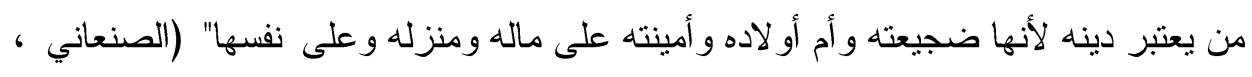

$$
\text { . (11)/ } 197 \text { : } 197 .
$$

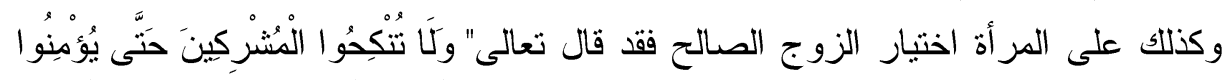

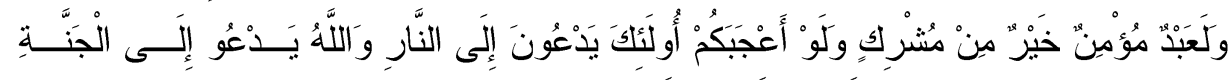

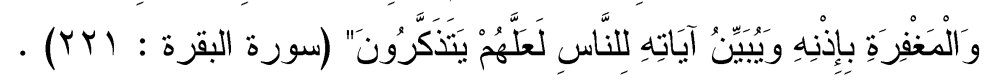

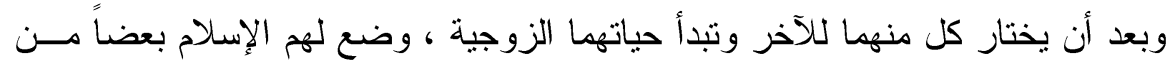

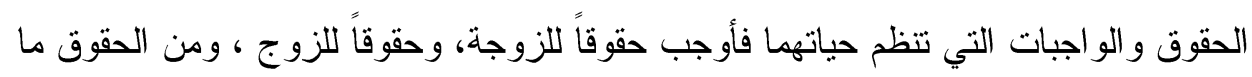


بعض قيم التسامح في الفكر التربوى الاسلامى وكيفية تعزيزها داخل الجامعات المصرية لمواجهة العنف المجتمعى

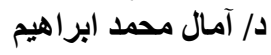

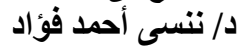

هو مشترك بينهما مثل حق العشرة بالمعروف بينهما وهو حق مشترك قال تعالى :" وَََهُنَّ مِنْلُ

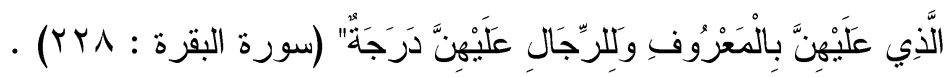
وقد قال الجصاص في تفسيره لهذه الآية:" أخبر اللّه تعالى في هذه الآية أن لكل و احــد

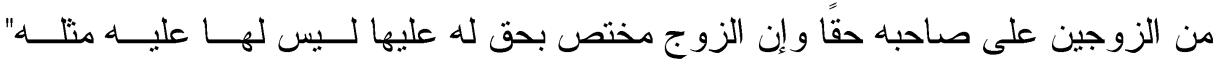

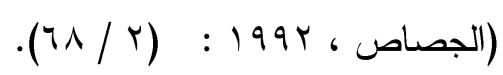

كما قال القرطبي:" أي لهن من حقوق الزوجية على الرجال مثل ما للرجــال علـيهن، ولهذا قال ابن عباس: إنى لأنزين لامر أتي كما تنزين لي، وما أحب أن استتظف" (القرطبـي، r

و إذا رزقهم الله الذرية فعليهم أن يتعاملو المعهم ضمن سلسلة من الأنظمة و التوجيهـات

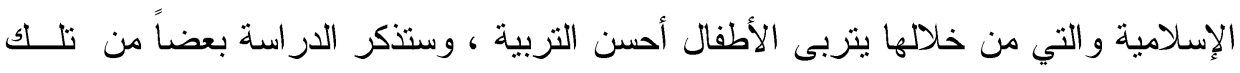
التوجيهات على سبيل المثال لا الحصر:

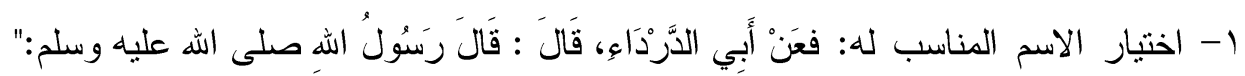

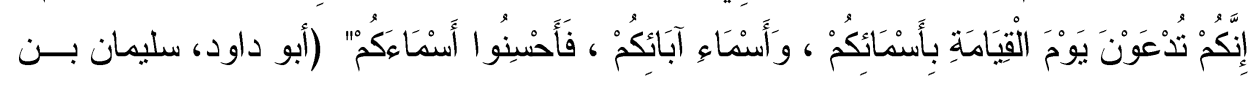

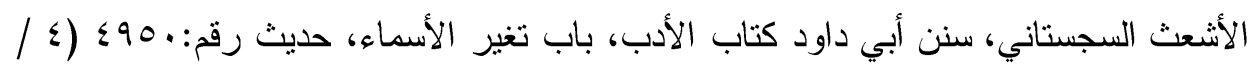
r- أن يحسن الأب تعليم الأولاد وتربيتهم التربية الصحيحة من الأخــلاق والآداب وتعــاليم

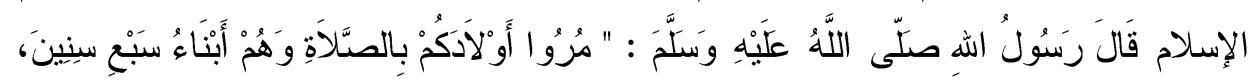

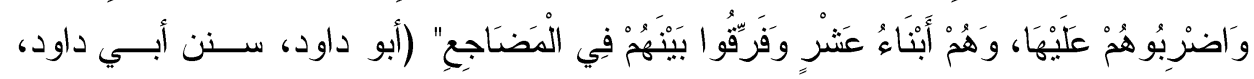
كتاب الصدلاة، باب متى يؤمر الغلام بالصدلاة، حديث رقم: 90؛ (1 / 1 ( ) ).

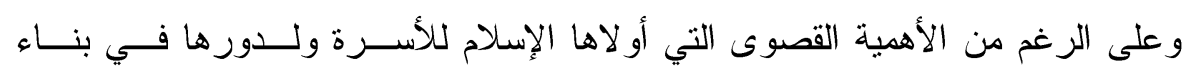

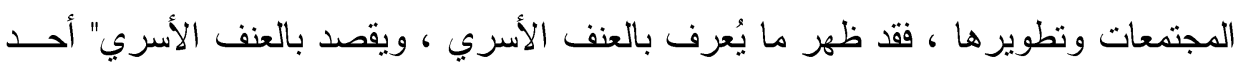
أنماط السلوك العدو اني الذي ينتج عن وجود علاقات قوة غير متكافئة في إطار تقسيم العمـلـل بين المر أة والرجل داخل الأسرة" (ليلى عبد الوهاب، . . . . : 7 ( ) . ويمكن تقسيم العنف الأسري إلى العنف ضد المر أة

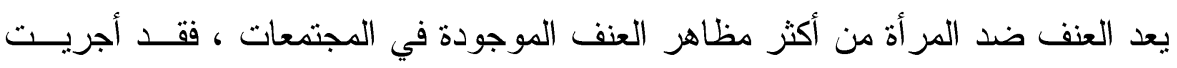
در اسات كثيرة لمظاهر العنف ضد المر أة وخلصت تلك الدر اسـات إلى نتــائج متعــددة منهـــا

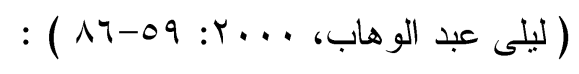


بعض قيم التسامح في الفكر التربوى الاسلامى وكيفية تعزيزها داخل الجامعات المصرية لمواجهة العنف المجتمعى د/ آمال محمد ابر اهيم المنف المجنم

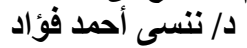

1. أن العنف ضد المرأة قد يكون على أثكال متعددة فقد يكون عـن طريــق الثـــتم

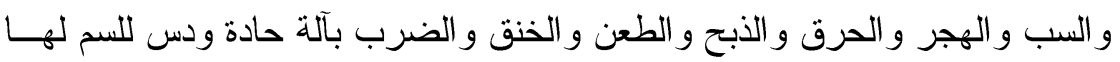

في الطعام.

r. من أثنكال العنف ما هو من أقل الدرجات مثل السب و الثنتم و الهجر ومنها ما قــد

يصل إلى أقصى الدرجات مثل القتل والحرق و الصعق بالتيار الكهربائي وغيرها.

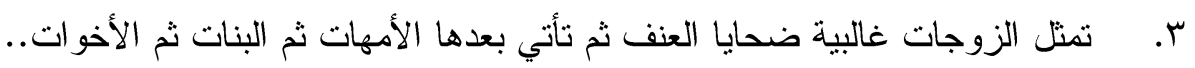

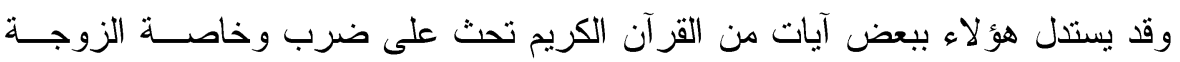

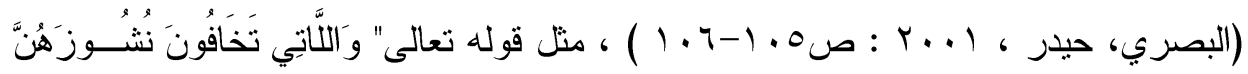

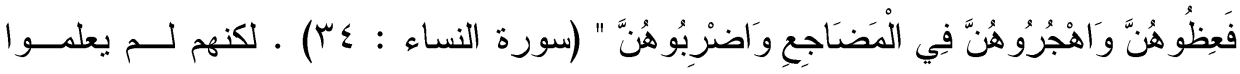

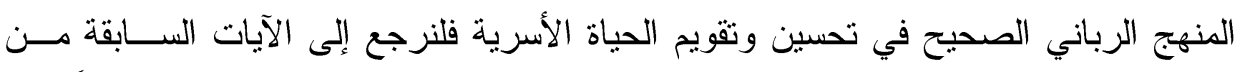

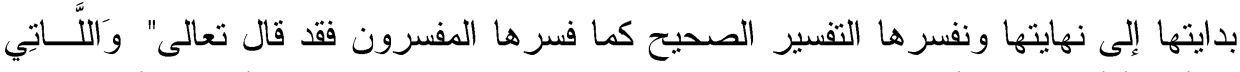

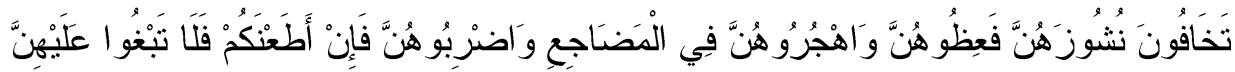

سَبيثًا إنَّ اللَّهَ كَانَ عَلَيَّا كَبيرًا.

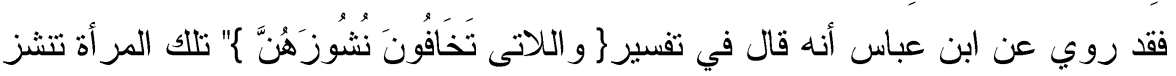

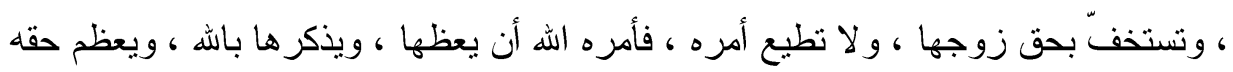

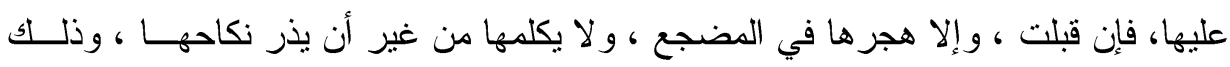

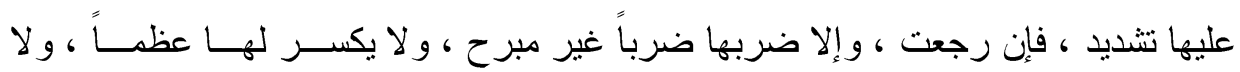

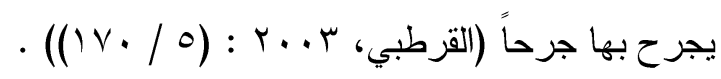

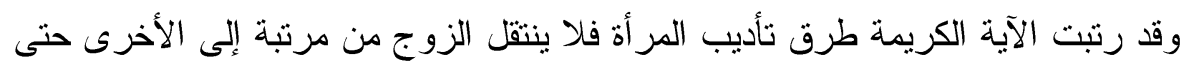

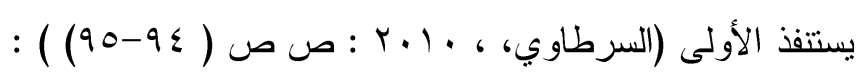

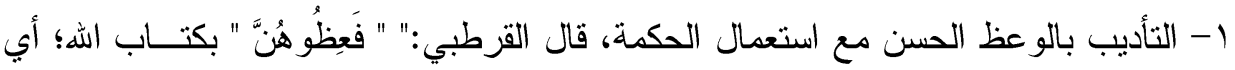

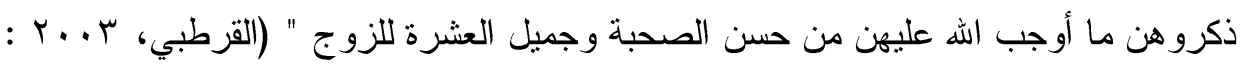

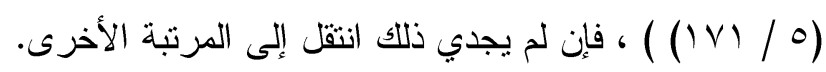

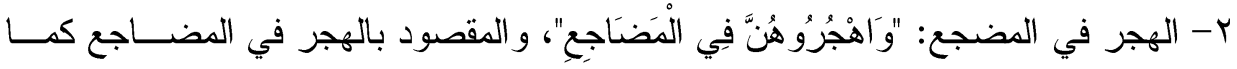

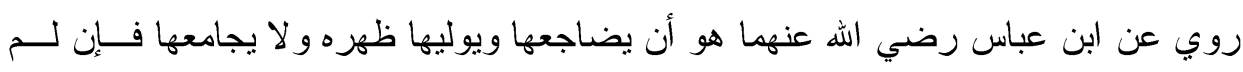

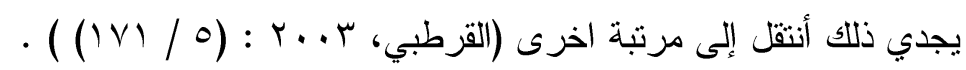

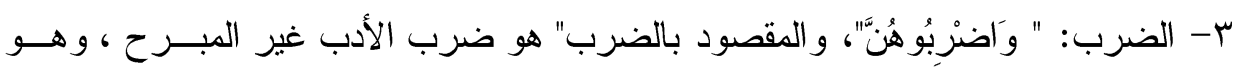

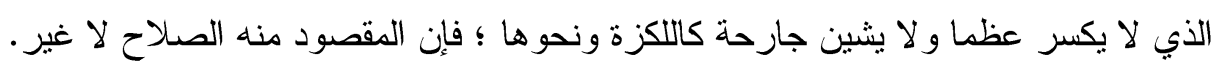

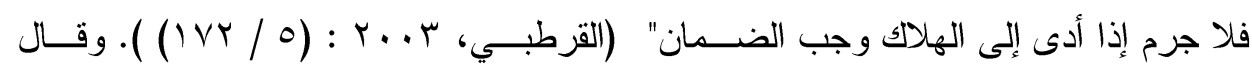




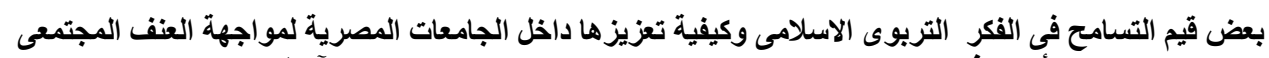
د/ آمال محمد ابر اهيم المهن

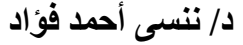

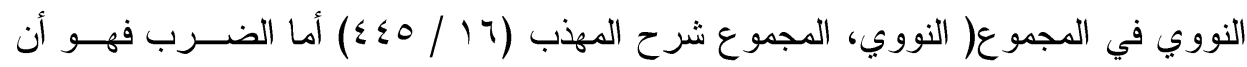
يضربها ضرباً غير مبرح ويتجنب المو اضع المخوفه و المو اضع المستحسنة". العنف ضد الأطفال

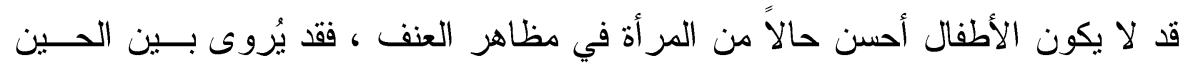

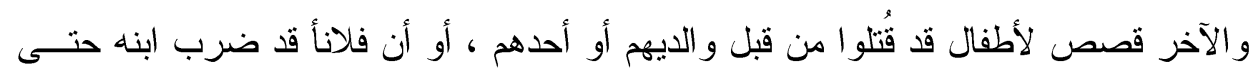

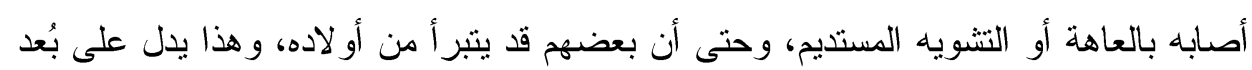

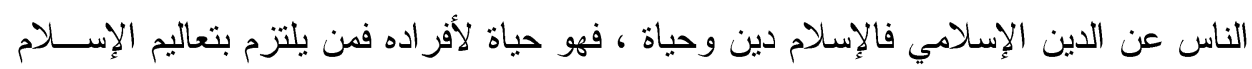
يعلم أن الأطفال أمانة من اله تعالى استأمننا عليهم.

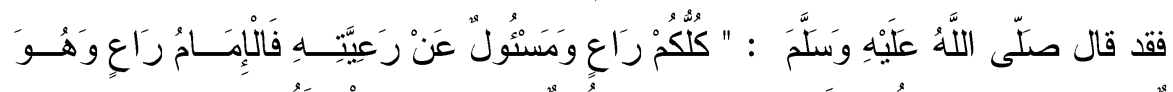

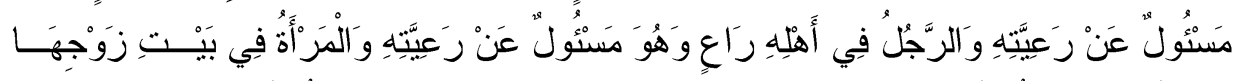

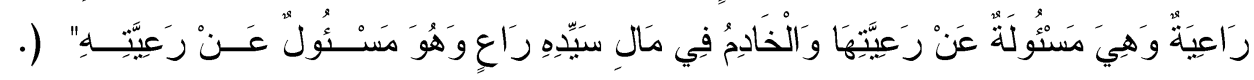

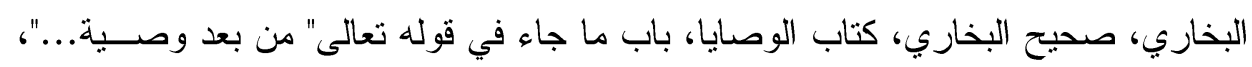

$$
\text { رقم: . . آب }
$$

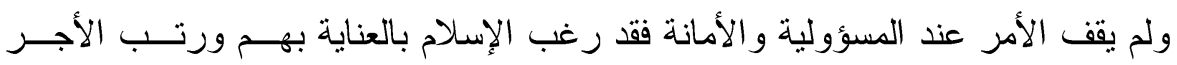

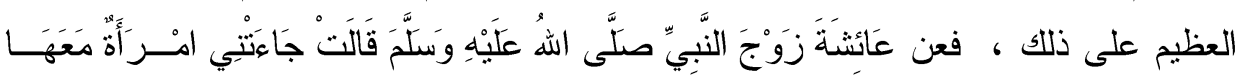

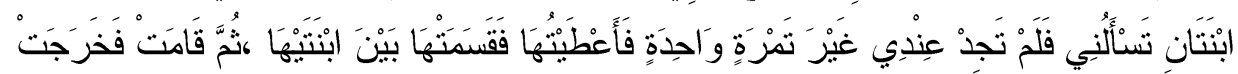

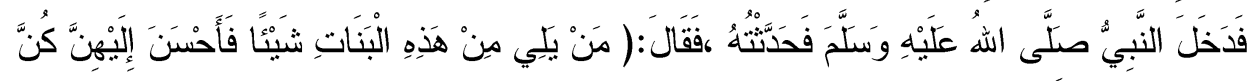

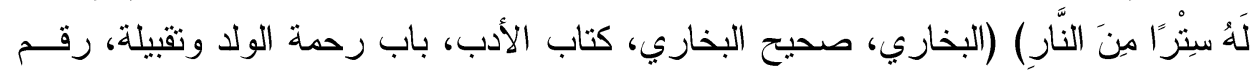

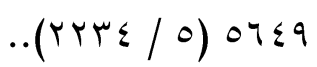

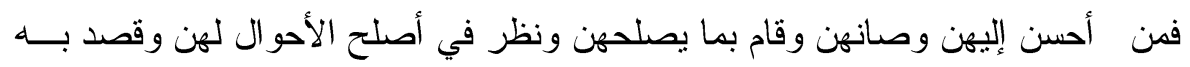

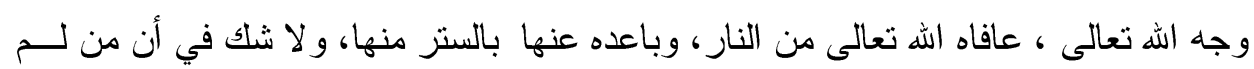

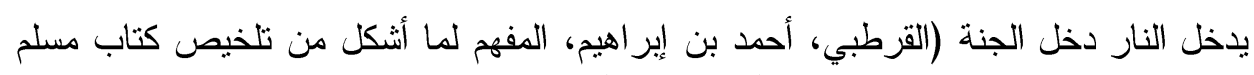

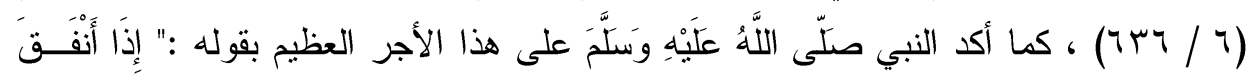

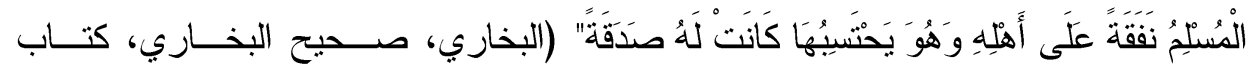

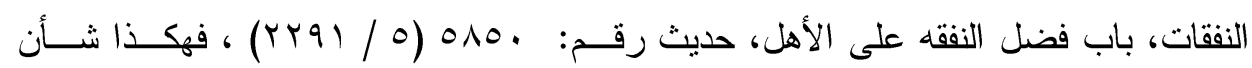
الإسلام دائما بالتز غيب في فعل الخير .

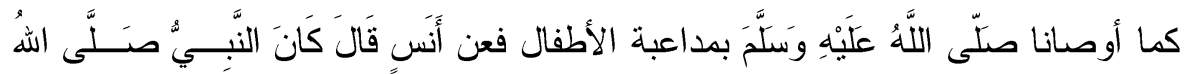

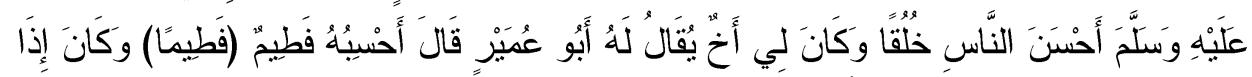

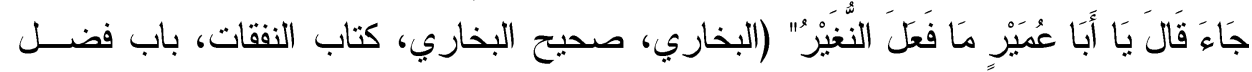


بعض قيم التسامح في الفكر التربوى الاسلامى وكيفية تعزيزها داخل الجامعات المصرية لمواجهة العنف المجتمعى آمال

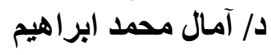

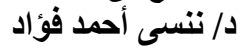

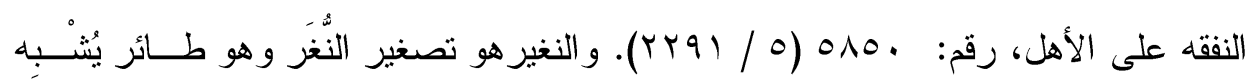

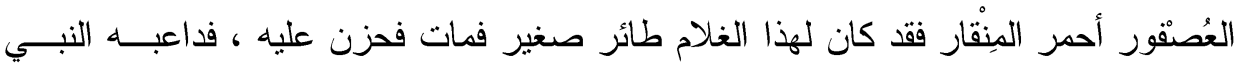

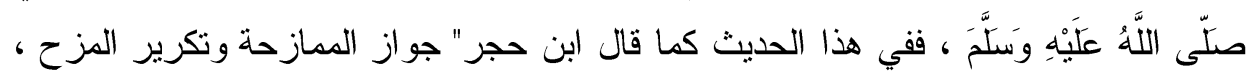

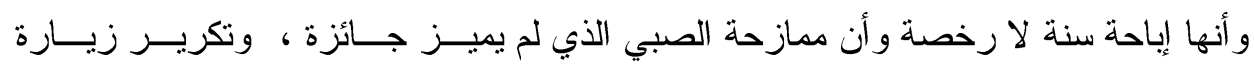

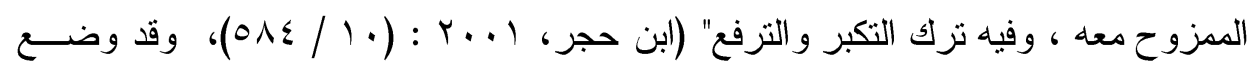
الإسلام حقوقاً عدة للأطفال لا يجب التهاون أو التقصبر فئها منها:

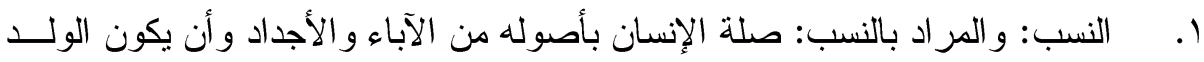

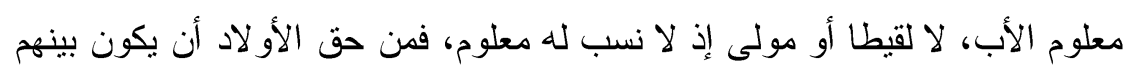

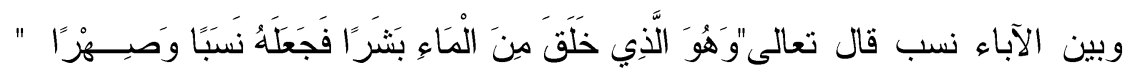

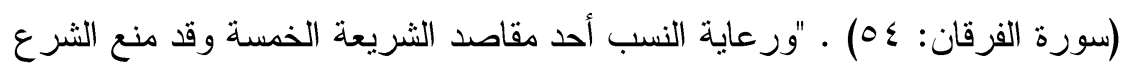

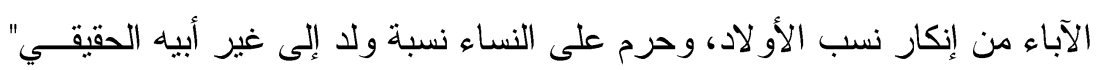

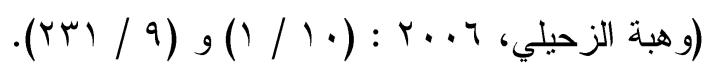

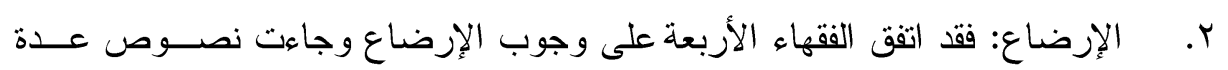

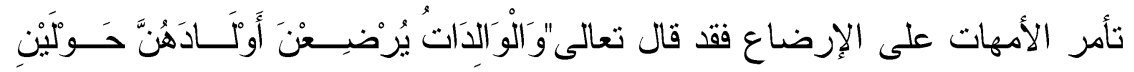

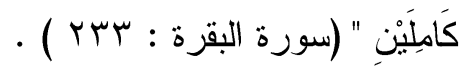

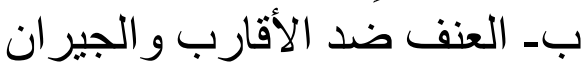

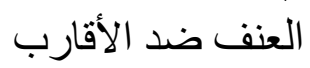

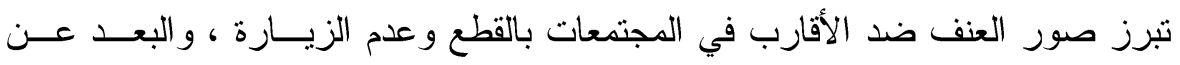

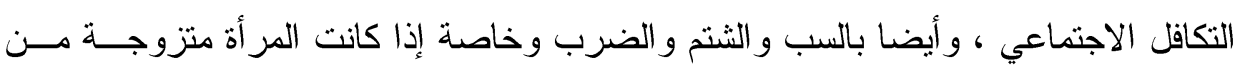

$$
\text { شخص قريب منها. }
$$

لكن هذا عكس ما يحث عليه الإسلام فقد حث على صلة الرحم في كثير مـن الآيـات و الأحاديث الثريفة ، و المقصود بالرحم الأقارب سواء كانوا من المحارم أو من غيرهم هم، فال

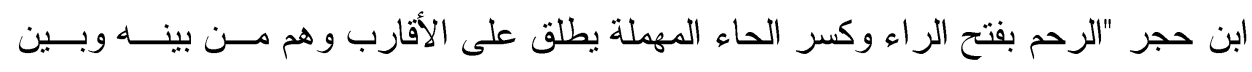

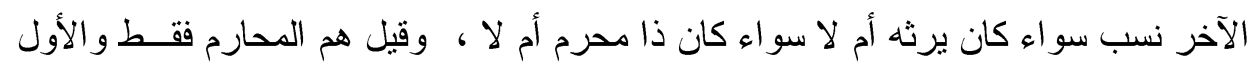

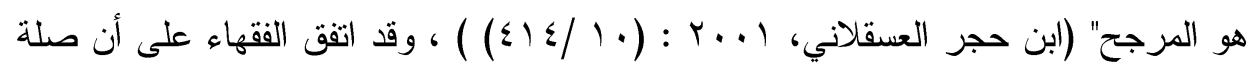

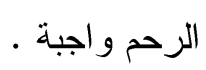

ومن الآيات و الأحاديث التي تحث على صلة الرحم:

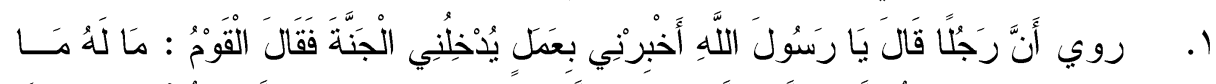

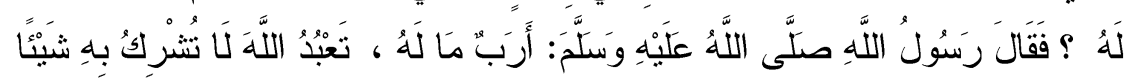




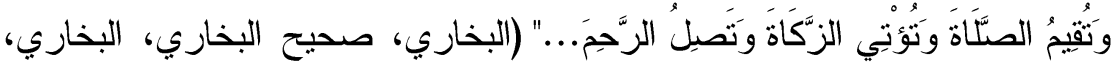

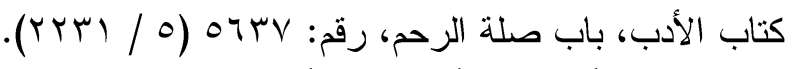

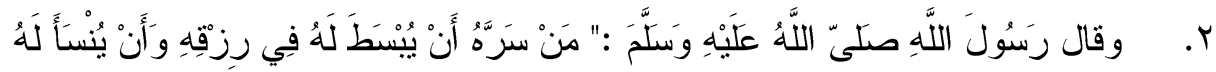

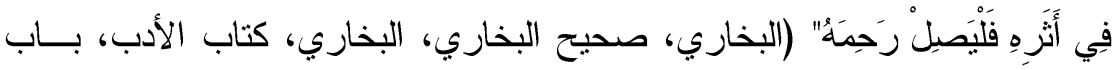

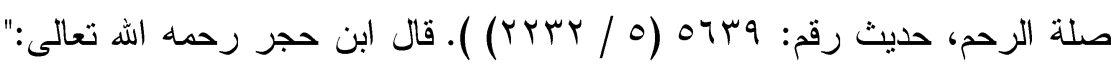

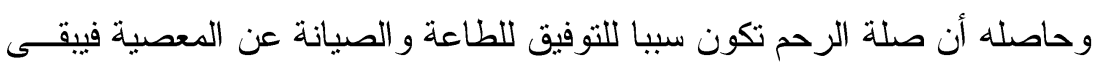

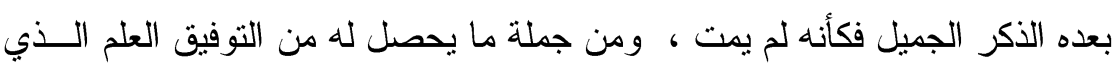

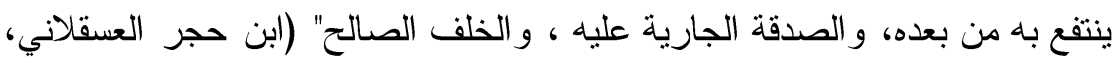

$$
\text { ( ) ( }(17 / 1 \cdot): \text { : r...) }
$$

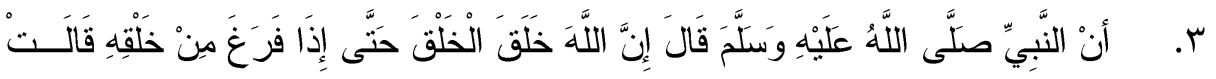

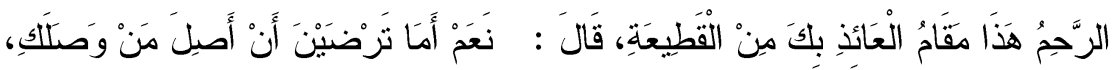

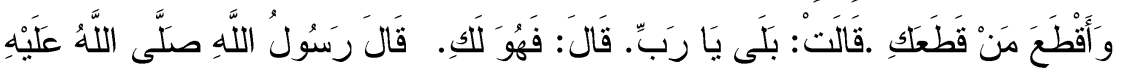

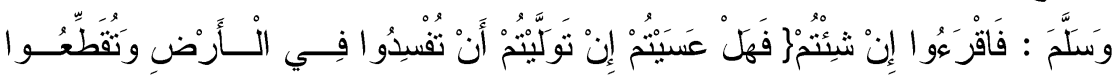

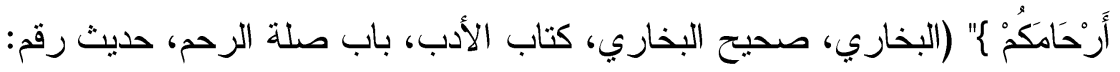

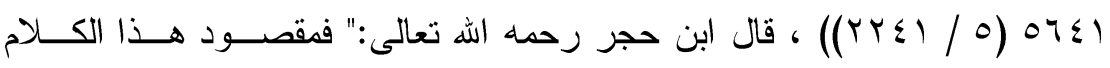

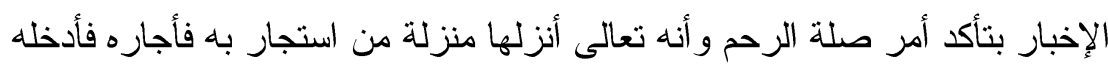

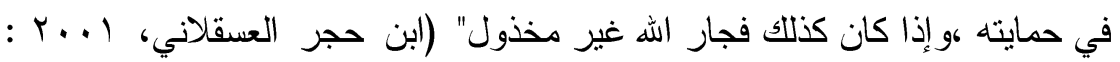

$$
\text { . (( } 1 \wedge / 1 \cdot)
$$

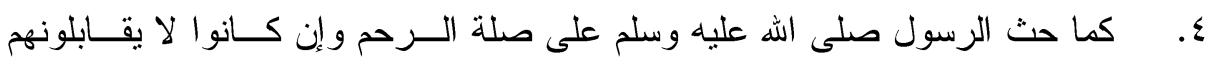

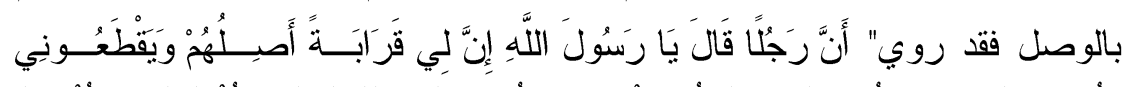

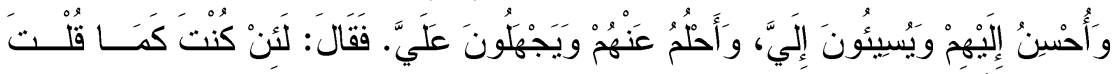

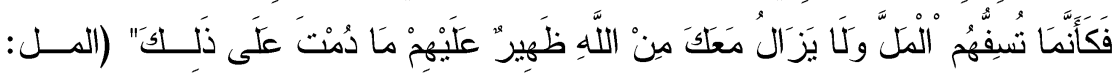

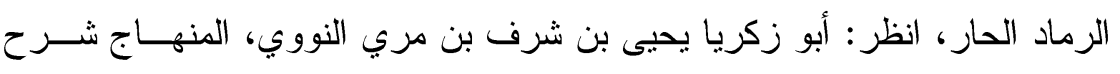

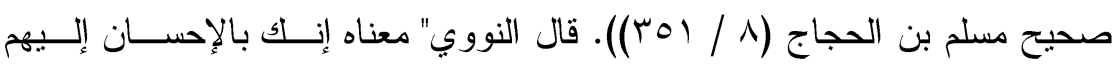

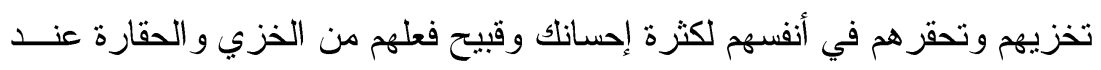

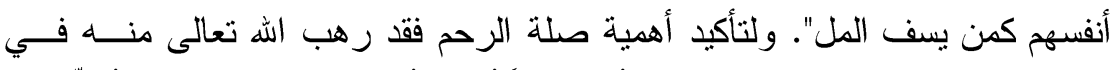

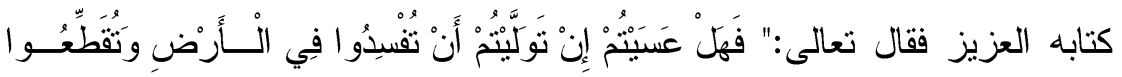

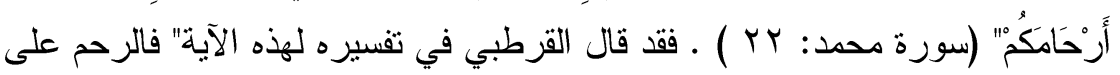

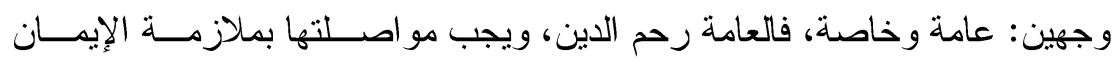




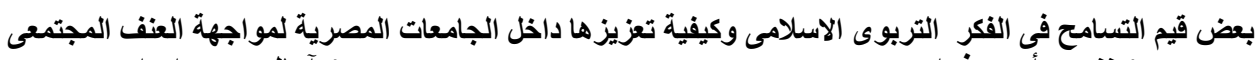
د/ آمال محمد ابر اهيم المنف المجنم

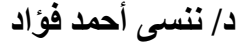

و المحبة لأهله ونصرتهم، و النصيحة وترك مضارتهم و العدل بينهم، و النصــفة فــي

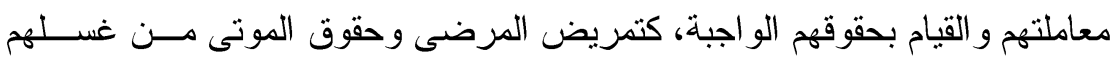

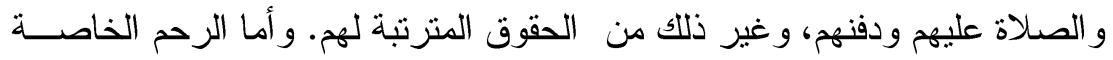

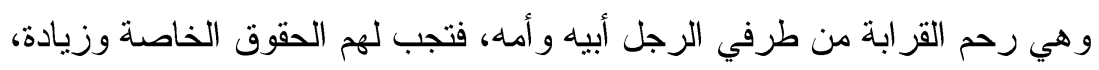

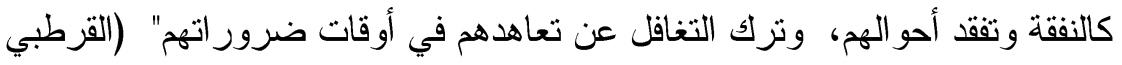

$$
\text { . }(r \leqslant \Lambda-r \leqslant V / 17): r \ldots r \text { ، }
$$

العنف ضد الجيران

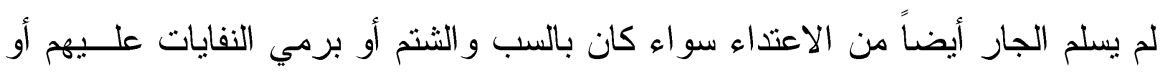

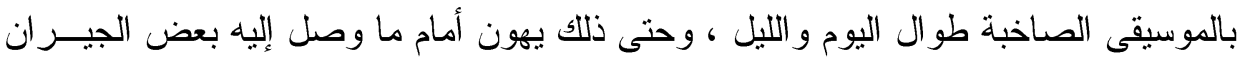

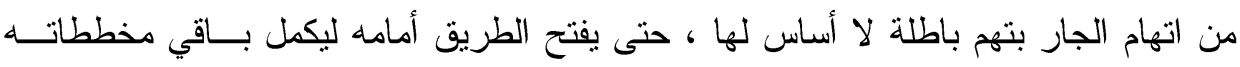

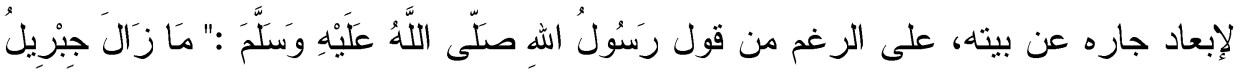

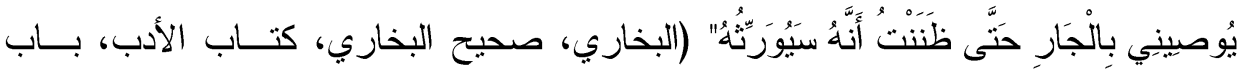

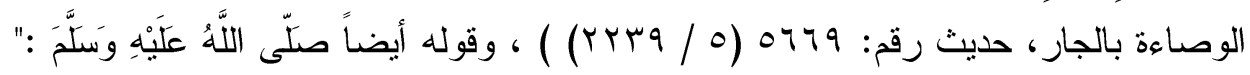

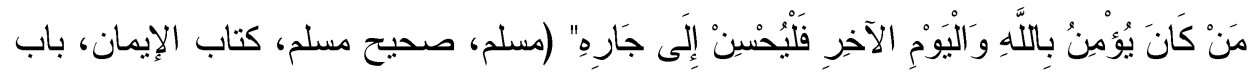

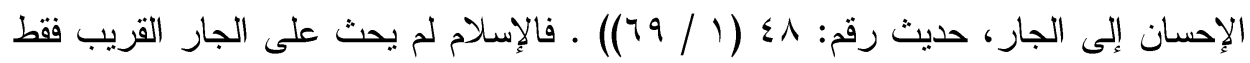

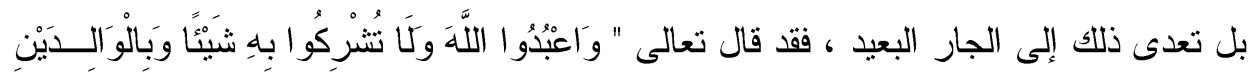

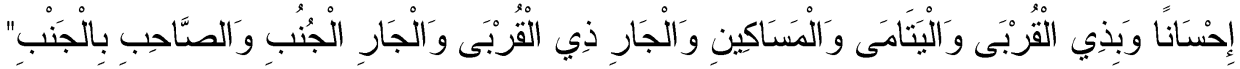

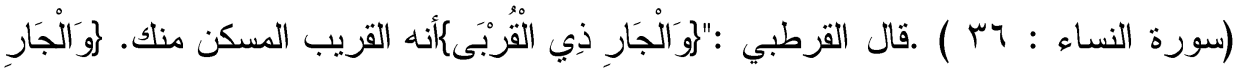

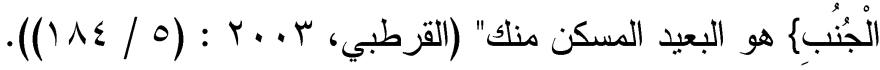

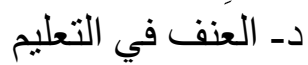

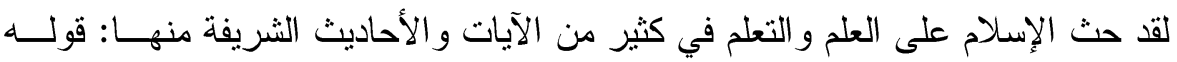

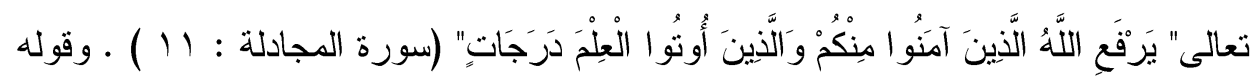

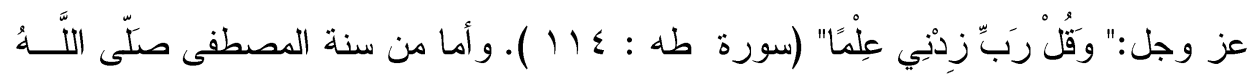

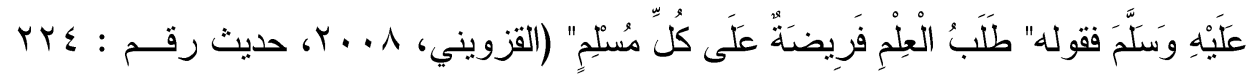

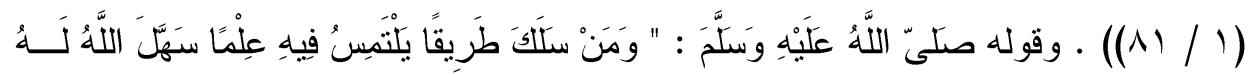

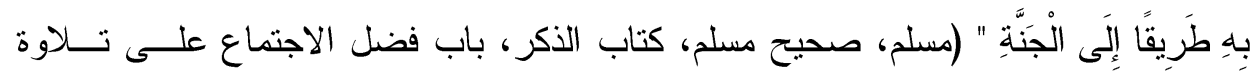

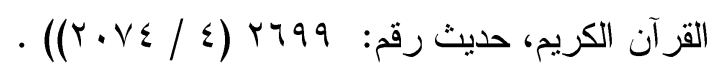




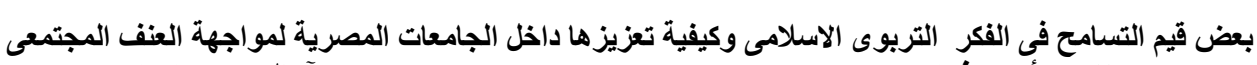
د/ آمال محمد ابر اهيم المنف المجنم

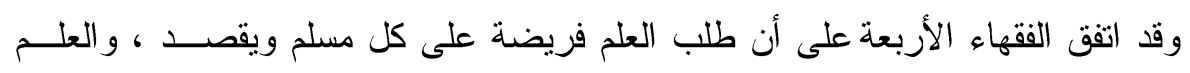
المفروض على كل شخص هو ما يحتاج إليه لإقامة الفرائض. وقد بعتري طلب العلم الألمكام

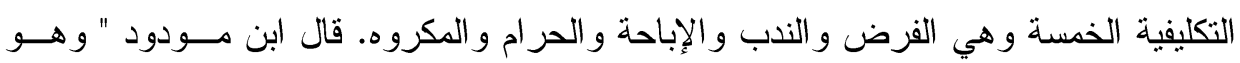

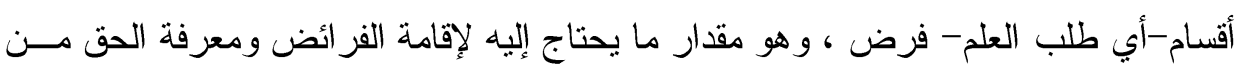

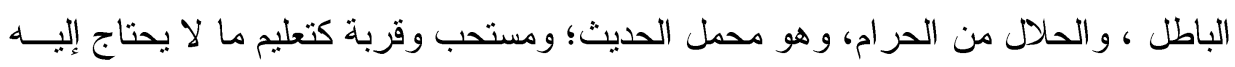

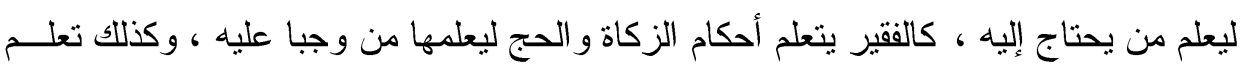

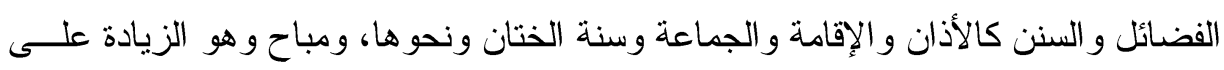

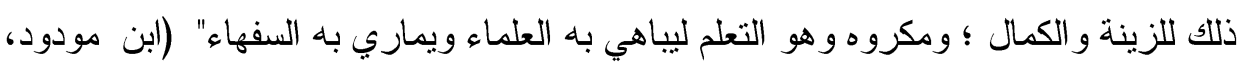

$$
\text { - (() }(1 / \varepsilon): \text { r... }
$$

وقد فضل الإسلام أيضـا العلماء على غيرهم وجعلهم في منزلـــة الصـــيقين و النبيــين

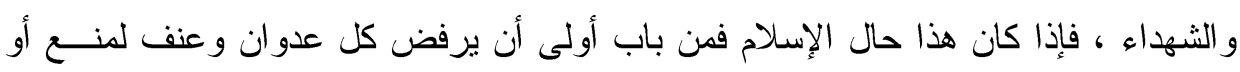

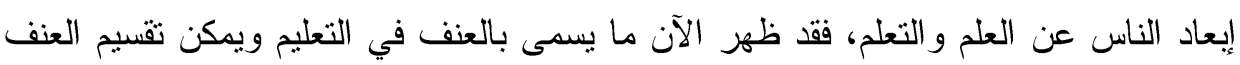

$$
\text { في التعليم إلى قسمين: }
$$

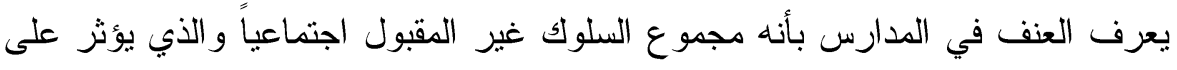
النظام العام للمدرسة ويؤدي إلى نتائج سلبية بخصوص التحصيل الدر اسي (حمدان، V. . . ب : . (ro

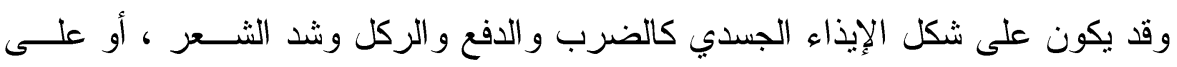
شكل الإيذاء اللفظي كالثتنم و السب و السخرية. العو امل التي تؤدي إلى العنف المدرسي قد تتجلى في عدة نقاط.

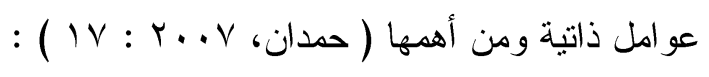

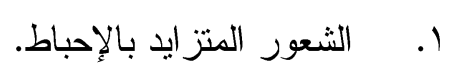
r. بعف التقة بالنفس.

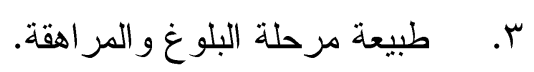

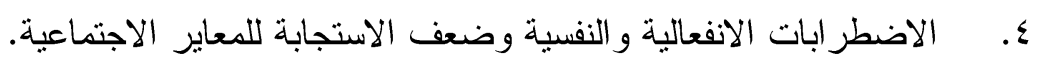

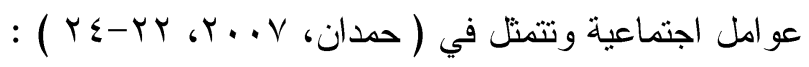

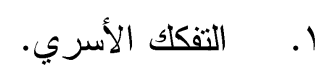

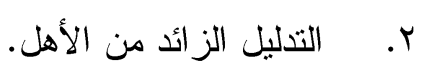




$$
\begin{aligned}
& \text { س. القسوة الز ائدة من الأهل. } \\
& \text { ع. عدم متابعة الأسرة للأبناء. }
\end{aligned}
$$

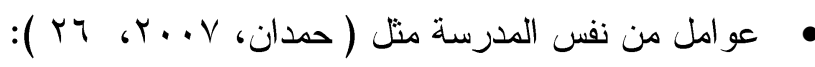

$$
\begin{aligned}
& \text { ا ـ غياب القدوة الحسنة. } \\
& \text { r. غياب التوجيه و الإرشاد. } \\
& \text { r. ممارسة اللوم المستمر من قبل المدرسين. } \\
& \text { ع. عدم الاهتمام بمشكلات الطلبة } \\
& \text { العنف في الجامعات }
\end{aligned}
$$

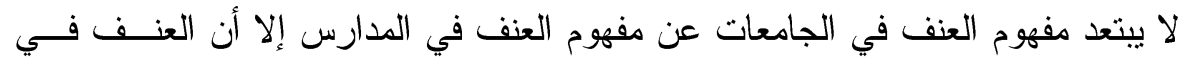

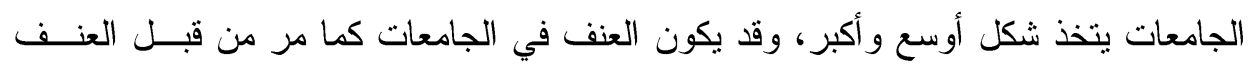

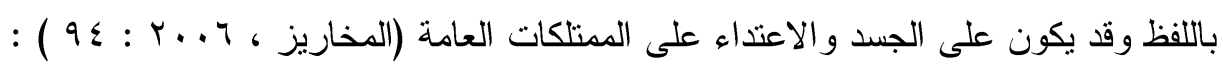

$$
\text { ويرجع الباحثون المعاصرون إلى أن أهم أسباب العنف في الجامعات هو : }
$$

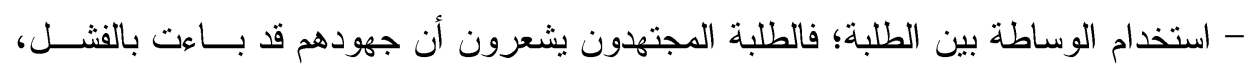

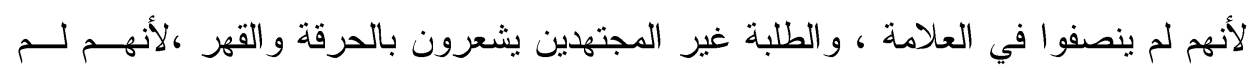
يحصلو ا على وساطة لرفع مستو اهم المتدني من التعلم في حين أن أصحاب الوساطة يتمتعون

$$
\text { بأعلى العلامات (المخاريز، } 7 \text {. . ب : 9^-9 ) ). }
$$

- ظلم بعض أعضاء هيئة التدريس وعدم إعطاء الطالب حقه في العلامات ، فنتائج البحوث

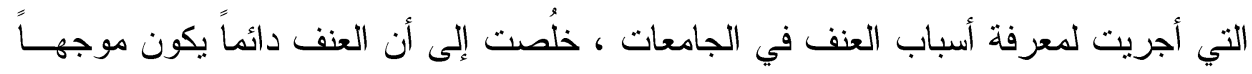
إلى أعضاء هيئة التذريس ، لأن هدف الطالب إكمــال تعليمـــه الجــامعي ، وأن أي قــرار

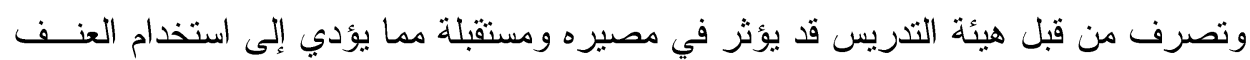

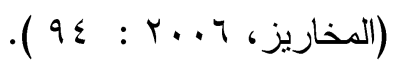

- الفراغ الروحي الذي تعيشه الأجيال و البعد عن الالتزام بشرع الله و أخلاقيات الإسلام.

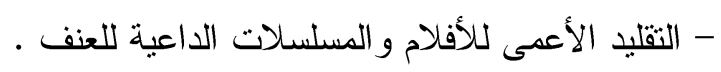
هـ- العنف ضد الحيو انات و الأشجار لقد أهتم الإسـلام بالحيو انات و الأشجار في كثيــر مــن الآيــات و الأحاديــث، فــبعض النصوص رغبت بالاعتتاء بالحيو انات ، ومنها ما نهت عن ضربها ، ومنها ما نهـت عـن وسمها وتعذيبها.

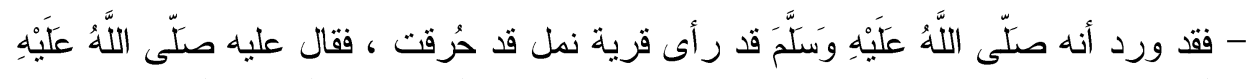

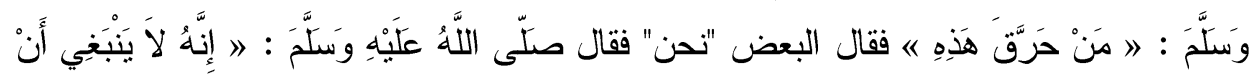


بعض قيم التسامح في الفكر التربوى الاسلامى وكيفية تعزيزها داخل الجامعات المصرية لمواجهة العنف المجتمعى د/ آمال محمد ابراهيم الهنف

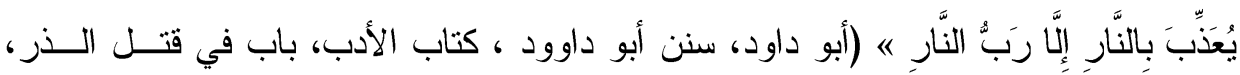

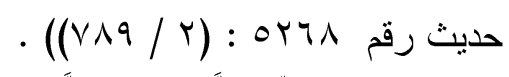

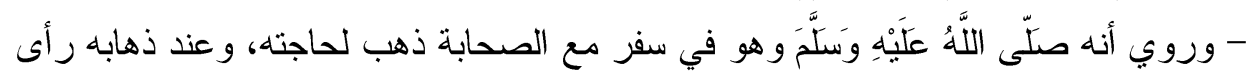

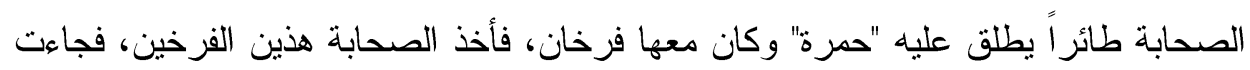

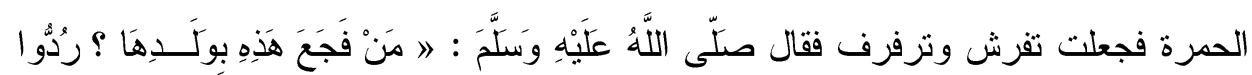

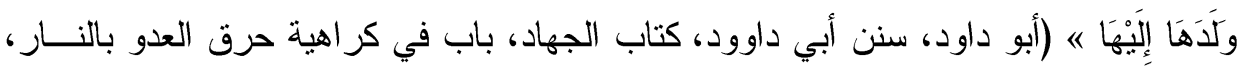

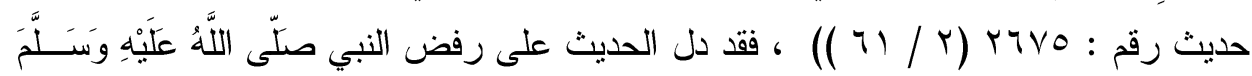

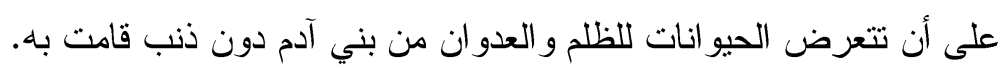

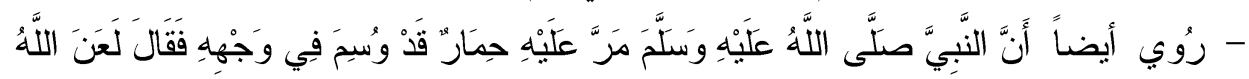

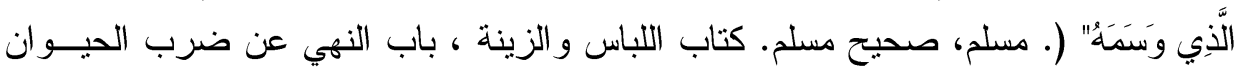

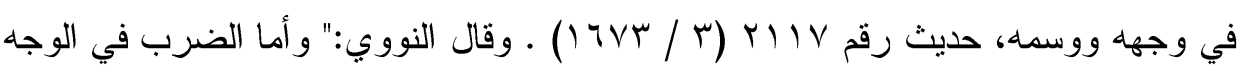

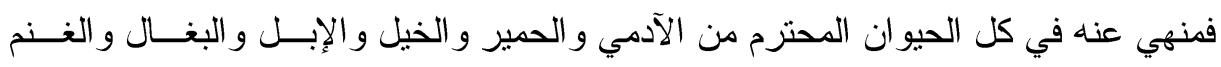

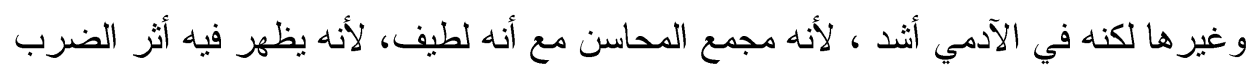

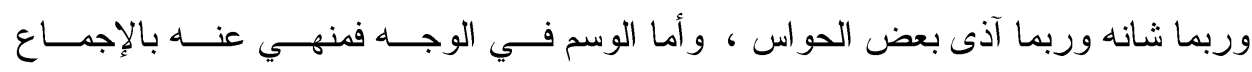

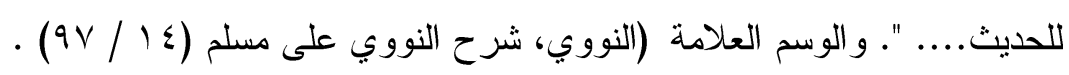
ولم يكتف الأمر على ذلك بل قد جعلت بعض الأحاديث جز اء الاعتداء على الحيوانـات

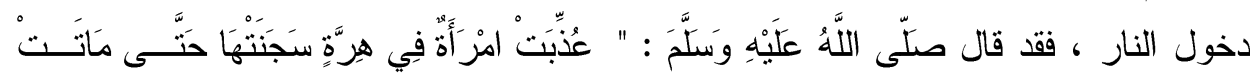

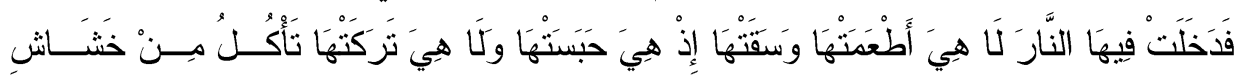

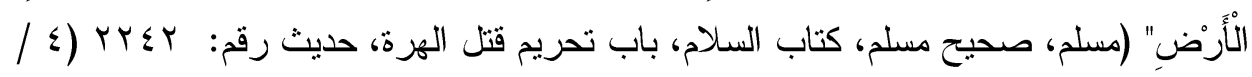
( ) 1 V .

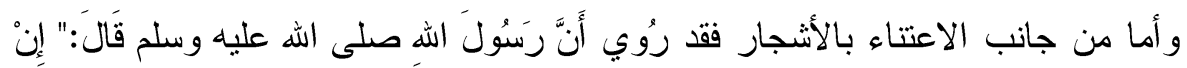

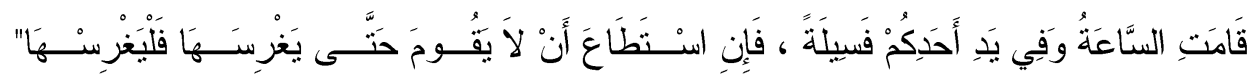

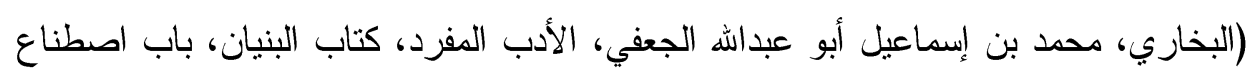

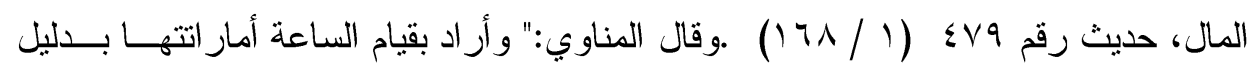

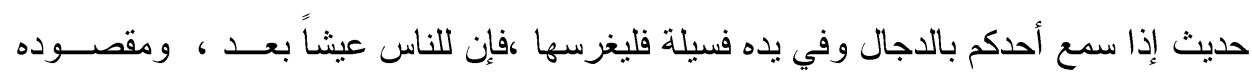

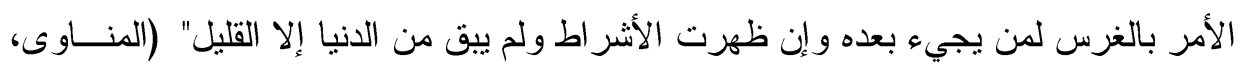
- $((\operatorname{vor} / 1): 1911$ 


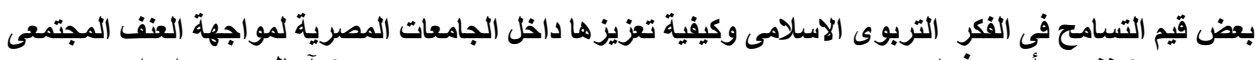

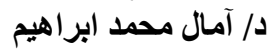

كما حث الإسلام على العناية بالأشجار و نهى عن إهلاكها ، وعُدَّ ذللك من الفساد المنهي

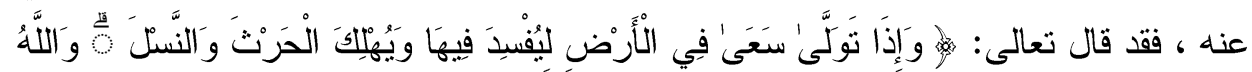

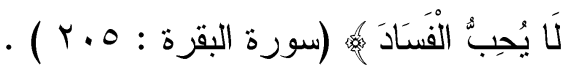
فقد دلت الآية على أن الحرث وزر اعة الأرض وغرسها بالأشجار شيء مفيد للإنســان، وأن

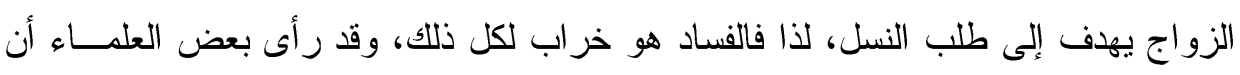
قطع الدر اهم من الفساد في الأرض ، فالآية بعمومها تعم كل فساد كان في أرض أو مــال أو هو

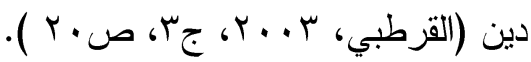

$$
\begin{aligned}
& \text { و - العنف العشائري و الديني }
\end{aligned}
$$

العشيرة هي الأهل والعون إذ يشتركون في الدية عن القتل الخطـأ، ويتعــاونون فـي الثدائد، وقد دخلت العشيرة في سياق التظيم السياسي في دولة الإسلام وقد حاول صلّى اللَّهُ عَلَيْهِ وَسَلَّمَ دمج العشائر في المجتمع الإسلامي لما لها من دور كبير في إرساء مبادئ الإسلام

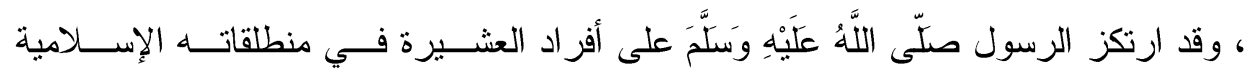

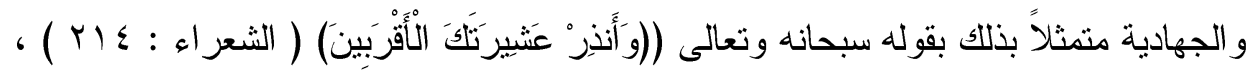

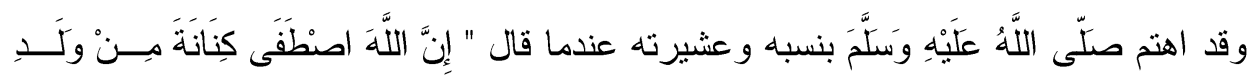

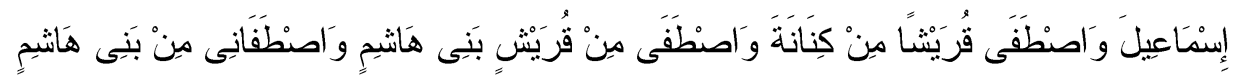

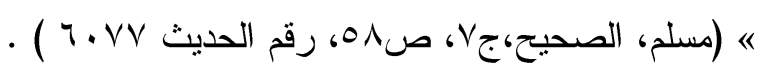

ومع محاسن وجود العشيرة المنطلقة من مبادئ إسلامية ، إلا أن البعض قد يسئ استخدام ا العشيرة ، اذ يلجأ البعض لتغطية جريمته بالغطاء العشائري، مع أن الإســلام لـــ يشــع العنصرية و لا الطائفية ، إذ لا فضل لجنس على جنس، ولا للون على لون ، و الميزان الوحيد

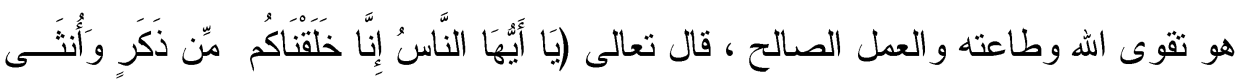

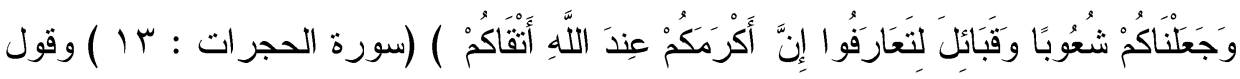

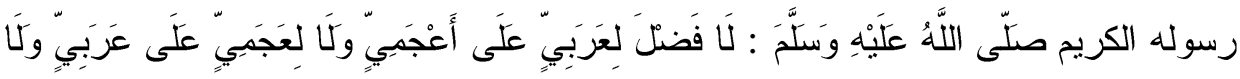

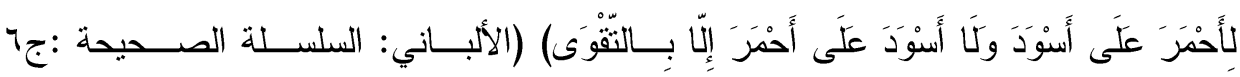
،صو9 99 ، رقم الحديث. . rV ) ، وقد أمر اله عز وجل بالإحسان إلى أهل الكتاب وأن لا

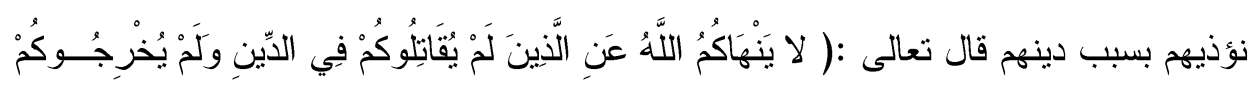

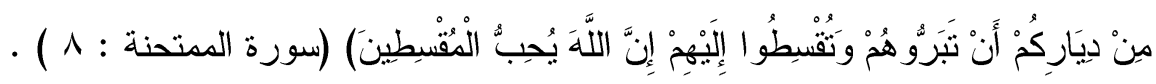




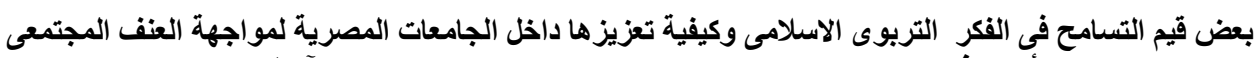

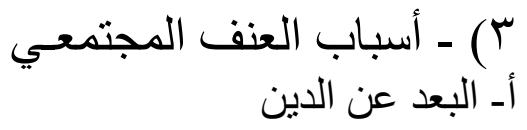

الإسلام دين الفطرة السليمة جاء ليخاطب العقل والفكر وهو دين المنهج الرباني لا يقر به نقص ولا تشوبه شائبة ، هو نظام الحق المستقيم الذي رضيه الله تعالى لنا ديناً ، فقد قــال

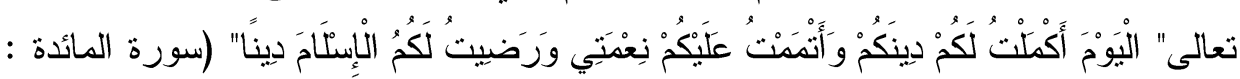
ץ ) ، ولن يكون الإسلام فقط بالقول باللسان بل اعتقاد بالقلب و عمل بالجو ارح، فاله تعالى لن يقبل العمل بالقول فقط أو بالاعتقاد فقط بل يقبله متمثلاً في حياة الأفر اد بالعمــل ، و عنــدما

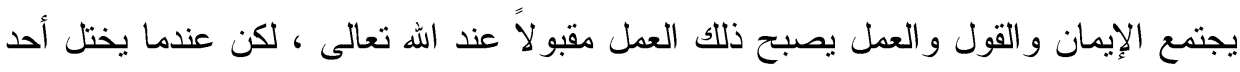
الأركان يؤدي إلى ضياع وشتات الأفر اد فينعكس ذلك على المجتمع بصورة سـلبية ، ويعـد البعد عن الدين السبب الأول و الرئيس لظاهرة العنف وذلك يتلخص بعدة أمور (أبو ليلى، فرج

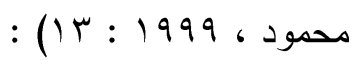

ا. أن من لا يلتزم بتعاليم الإسلام يكون قريباً من كل شيء حرمــه الله تعـالى ، فــلا يستطيع أن يفرق بين ما هو حلال وما هو حرام ، فيلجأ الثخص إلى السب و الثتن

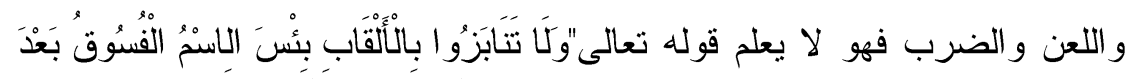

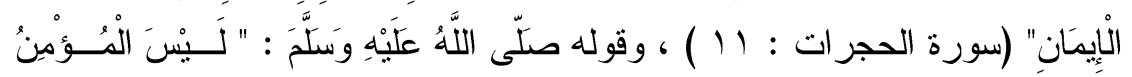

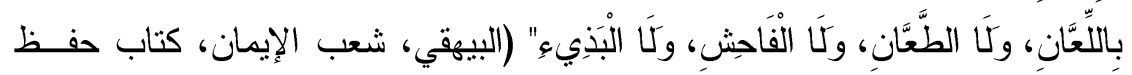

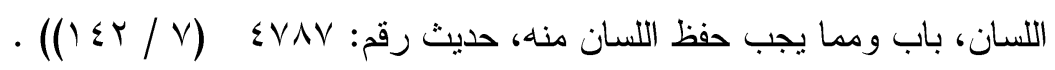

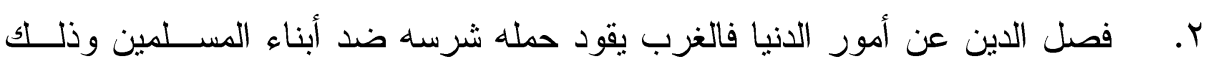
بنشر العلمانية بينهم و إبعادهم عن الدين ولم يعلم أبناء المسلمين أن ديننا الإســلامي هئي نظم جميع أمور الحياة بكافة جو انبها. س. تحكيم غير شرع الله تعالى بين أبناء المسلمين وقد أدى ذللك إلى الثــعور بــالظلم و عدم العدل لأنه لم يشعر أنه قد أخذ حقه من غريمه فيضطره ذللك إلى العنف وذللك

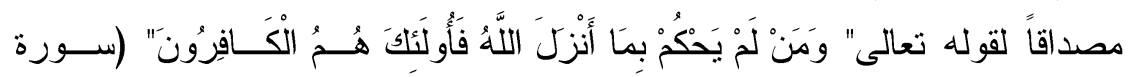

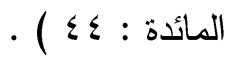

$$
\begin{aligned}
& \text { بـ الأسباب الاجثماعية }
\end{aligned}
$$

ويتمثل ذلك في العادات والتقاليد التي اعتادها المجتمع والتي تتطلب من الرجل قدراً من الرجولة فإن الرجل في بيته يجب عليه أن يستخدم العنف مع أسرته و العنف هو المقياس الذي يمكن من خلاله معرفة المقدار الذي يتصف به الإنسان من الرجولة وإلا فهو ساقط من عداد

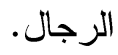


بعض قيم التسامح في الفكر التربوى الاسلامى وكيفية تعزيزها داخل الجامعات المصرية لمواجهة العنف المجتمعى

ومن الأسباب الاجتماعية أيضا تعدد الزوجات بدون مبرر شرعي وخاصة إذا صــاحبه

تفضيل إحدى الزوجات على أخرى أو إهمال الزوجة الأولى وعدم تلبية احتياجاتها.

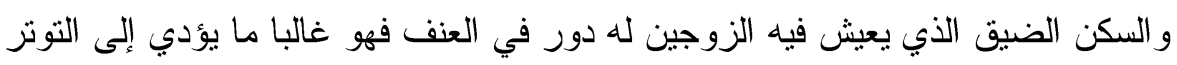

الدائم بين أفراد الأسرة بسبب عدم توفر المساحة اللازمة للحركة وينعكس هذا التوتز علــى لـونى

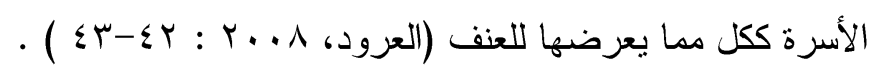

و أيضـا قد يكون من أسباب العنف العنف المنتشر عربياً وعالميــاً والتـي تثتقـلـل عبــر

الفضائيات و الانترنت ، فالتغيرات التي تحدث في المجتمع الكبير تتنقل وبشكل غير مباشــر

$$
\text { جـ المى المجتمعات الصغيرة . }
$$

يرى بعض الباحثين أن العنف نابع عن اضطراب في نفسية الثخص الذي يمارسه قولاً وفعلاً دون أن يعيروا اهتماماً للظروف والأوضاع المحيطة بالفرد وتزجع الأسباب النفسـية

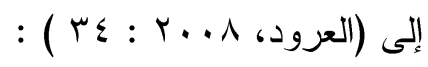

ا . أسباب ذاتية ترجع إلى شخصية القائم بالعنف كأن يكون لديه خلل فـي الشخصـية

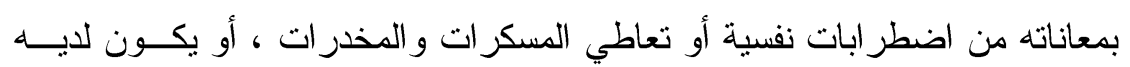

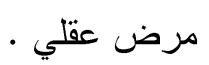

r. وقوع العنف على الأشخاص منذ صغرهم ، فقد أكدت الدراســات الحديثــة التــي أجريت على الأطفال أن الذي يُمارس عليه العنف باستمرار يتلبد الحس لديه ويصبح

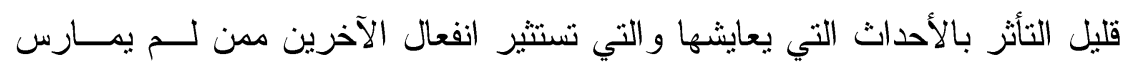

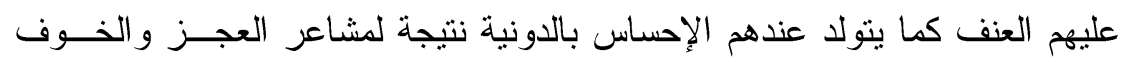
المترسخة مرة بعد مرة، وأن من يُمارس عليه العنف وهو صغير سيمارسه لاحقًا

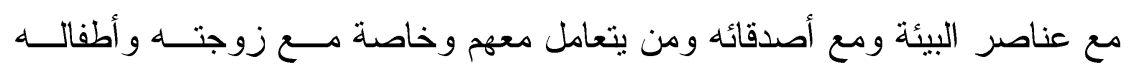

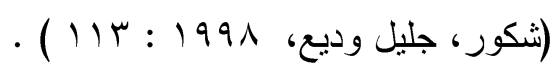

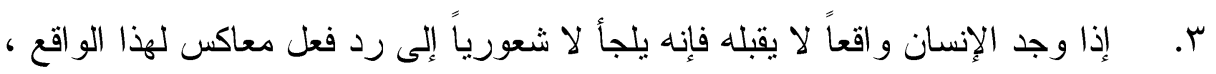

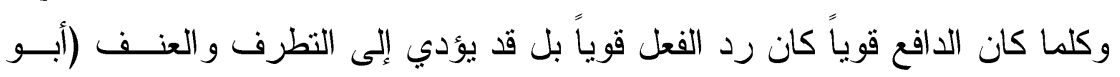

$$
\text { زنيد، ... }
$$

ء. أغلب أثنكال العنف الصادرة من الأفراد تكون وسيلة من الفرد لإيجاد حل لإعــادة التو ازن بينه وبين بيئته و التخلص من الصر اع الداخلي ، فيؤديه ذلك إلــى وســائل

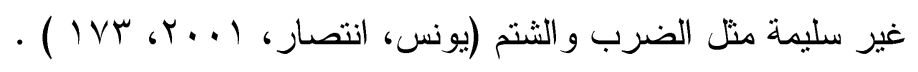


بعض قيم التسامح في الفكر التربوى الاسلامى وكيفية تعزيزها داخل الجامعات المصرية لمواجهة العنف المجتمعى آمال

ه. ومن الأسباب أيضاً شعور الشخص المتز ايد بالإحباط وضعف الثقة في النفس فيدفع

$$
\begin{aligned}
& \text { ذللك إلى العنف (حمدان، V . . r: هץ) . } \\
& \text { دـ الأسباب الاقتصسادية }
\end{aligned}
$$

قد تكون الأسباب الاقتصادية من أهم أسباب العنف مثل الفقز أو الدخل الضعيف الذي لا يكفي المتطلبات الأسرية ، أو حالة المسكن أو المنطقة التي يعيش فيها واستخدام الأب للعنف في الأسرة ليس لتحصيل المال منهم ولكن تفريغا لشحنات الخيبة و الفقر الداخلية ، و إذا كــان العنف في خارج حدود الأسرة فالسبب إنما هو الحصول على النفع المادي .

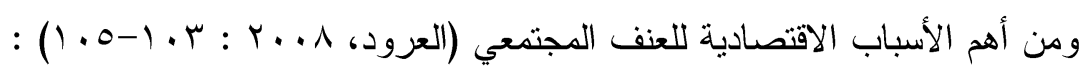

ا. سوء توزيع الثزوات ، فهناك الفئات التي تتصف بالغنى الفاحش وتتمتع بامتيــاز ات كثيرة بينما فئات أخرى لا تتال من الدنيا إلا الفقر المدقع. r. انتشار الطرق غير المشروعة في الكسب والحصول على الرزق مثــل : الرشــوة

$$
\text { و الربا و السرقة و غير ها. }
$$

r. غياب روح التكافل الاجتماعي ، وسبب ذللك أن الأغنياء لا يخرجون زكاة أمو الهم

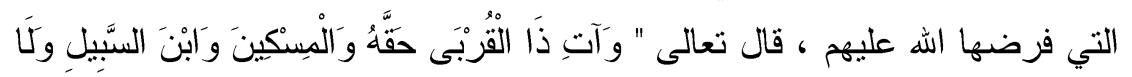

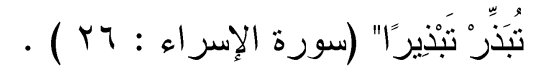

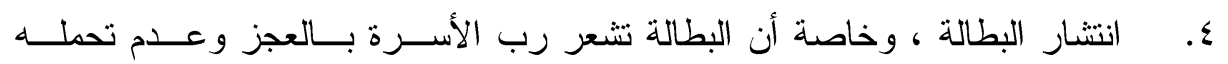
المسؤولية ، مما يؤدي إلى فقدان ثقته بنفسه وتفقده الثعور بالاطمئنان فيظهر العنف ولف وله

$$
\text { و الثقاق و النز اع في الأسرة. }
$$

ويتضح مما سبق أن الإسلام قد اعتنى اثد العناية بتربية أفراده وتتظيم حياتهم في أمورهم

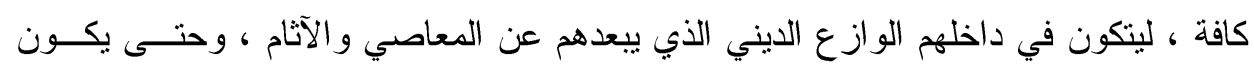
المجتمع في أوج قوته ، ولكن إذا خالف الأفر اد تعاليم الإسلام انحرفو ا وأصــــح كـلـ مــنهم

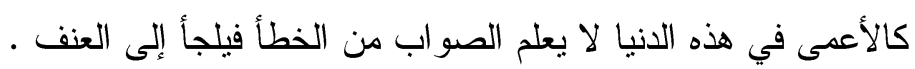
لذا كان لز اماً على جميع المؤسسات التربوية عامة و وعلى الجامعة خاصة أن تُحصنّن كل لأل فرد داخلها بمختلف أنو اع القيم وعلى رأسها قيم التسامح ، حتى تضمن خروج كو ادر مؤهلة

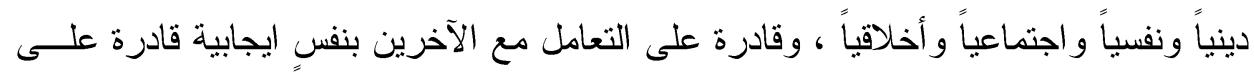

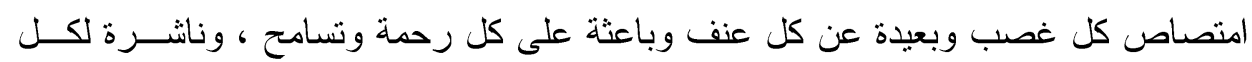

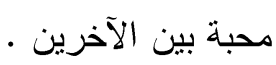
نتائج الدر اسـة

لقد توصلت الدراسة إلى العديد من النتائج منها : 
بعض قيم التسامح في الفكر التربوى الاسلامى وكيفية تعزيزها داخل الجامعات المصرية لمواجهة العنف المجتمعى آلمال د/ آمال محمد ابر اهيم المنف المجنم

د/ نتسى أحمد فؤاد الدي

ا- إن مواجهة العنف و التسلط لا يمكن أن تأتي عبر القرارات و القو انين النافذة ، و إنما تــتم

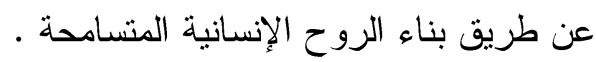

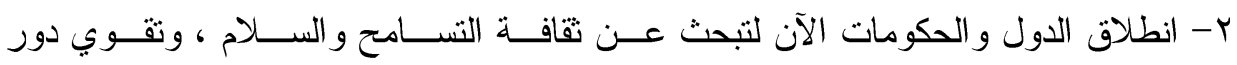

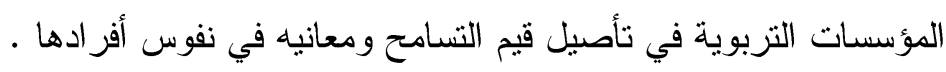

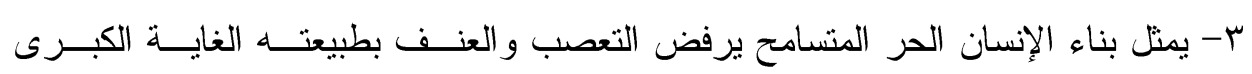
للتربية .

ع- يمثل التعليم الجامعي أخطر مراحل التعليم وأثدها تأثير اً في توجيهات حركة الفكر ، لأن الجامعات تستقطب مجتمع الثنباب الذين سيشكلون في المستقبل النخبة المثقةــــة ، القياديـــة ،

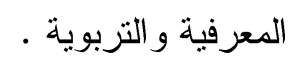

ه- ضرورة تكثيف الجهود وتنظيمها في الوسط الجامعي لتنشئة الطلبة و الطالبات على قـيم التسامح حتى تتنقل هذه القيم من خلالها إلى المجتمع بأكمله .

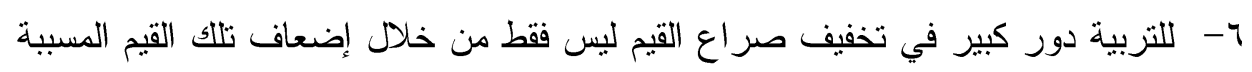

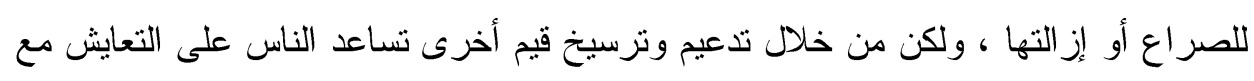

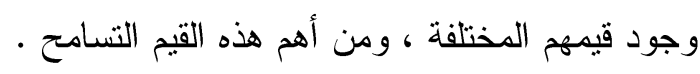

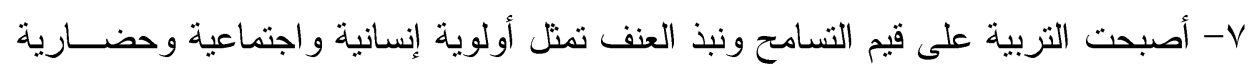

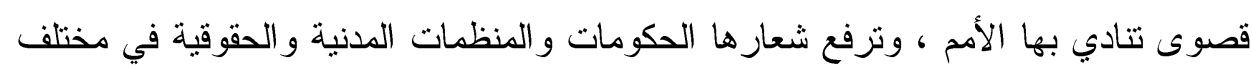

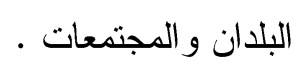
^- قد بلغت ظاهرة اللجوء إلى العنف كبديل للتحاور و التسامح الفكري مرحلة تتذر بأخطــاء

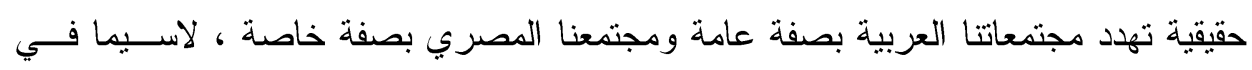

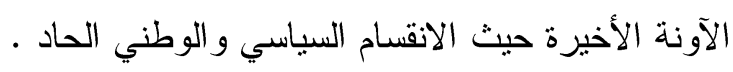
9- يتعين على القيادات التزبوية وو اضعي السياسات التعليمية و التزبوية اعتماداً على التربية

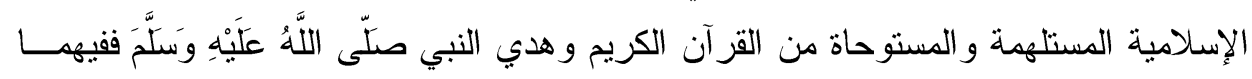

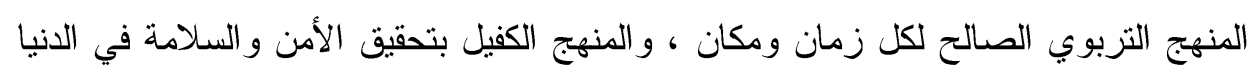
و الآخرة.

• 1- التسامح سلوك معبر عن امتتال الفرد لمنظومة من القيم الإنسانية والأخلاقية و الدينيــة

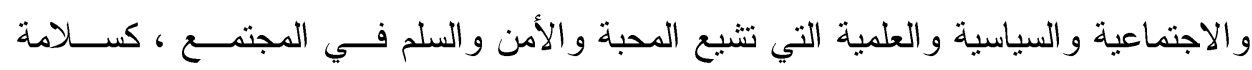

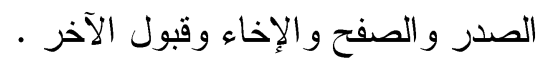

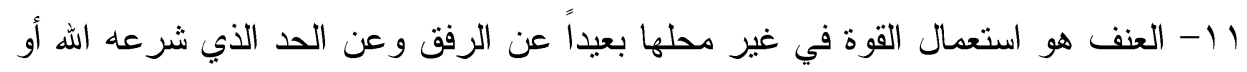

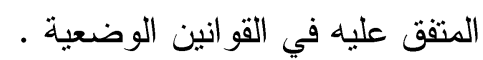


بعض قيم التسامح في الفكر التربوى الاسلامى وكيفية تعزيزها داخل الجامعات المصرية لمواجهة العنف المجتمعى آلمال د/ آمال محمد ابر اهيم المنف المجنم

r ا أن مشكلة العنف و التعصب و التطرف هي في أصل نشوئها وتتاميها مشكلة تربويــة ، لأنها تتعلق أساساً بغياب ثقافتي التسامح و الحرية في مختلف مناحي الحياة .

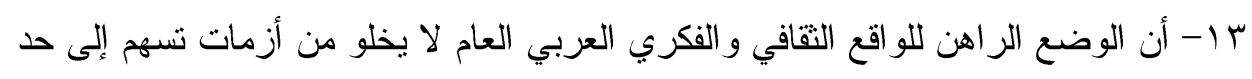

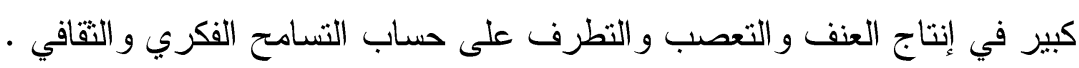

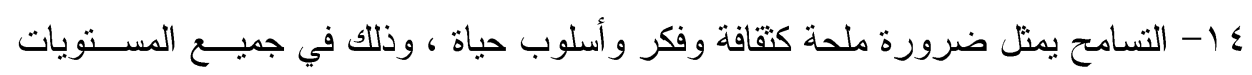

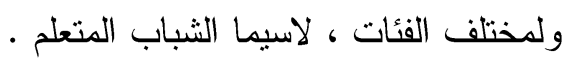

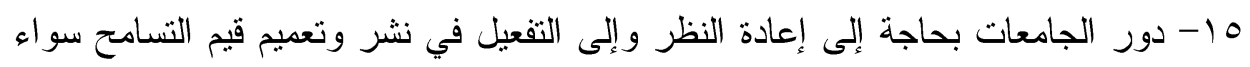

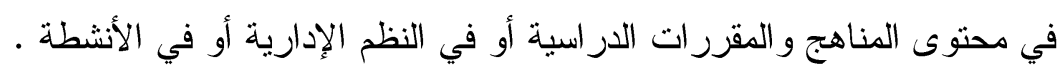

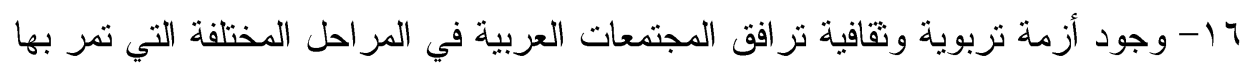

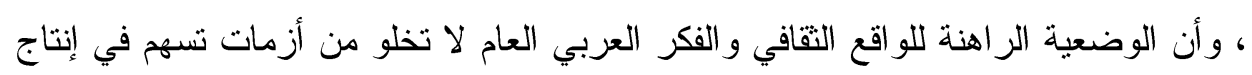

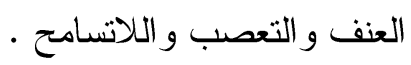

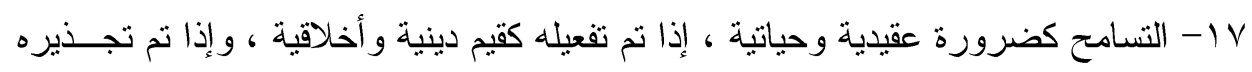

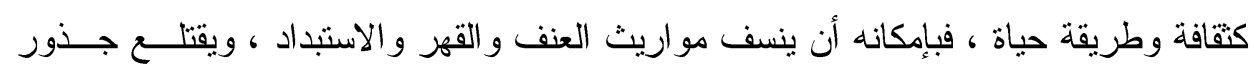
التعصب و الكر اهية. 11 - يمكن للجامعة أن تتجاوز الكثير من العقبات التي تعوق ممارسة التسامح ، وذللك بالعمل

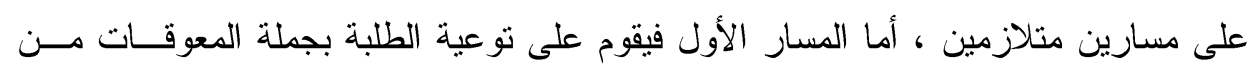

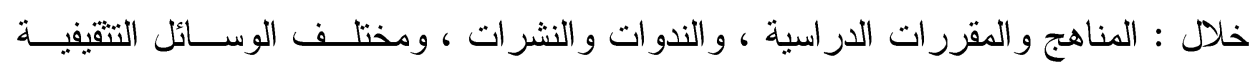

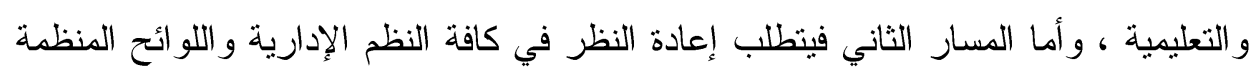
للعلاقات الأكاديمية و الاجتماعية و الإنسانية بين جميع العاملين.

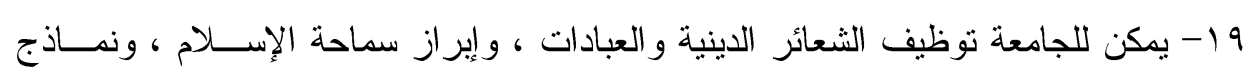

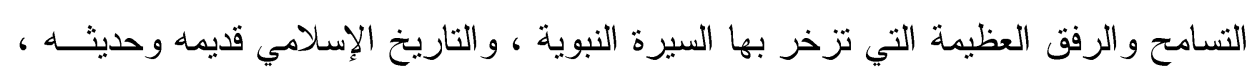
وتسليط الضوء بداية على آيات القر آن الكريم المتضمنة لروح التسامح و الحض عليه ، وكذلك

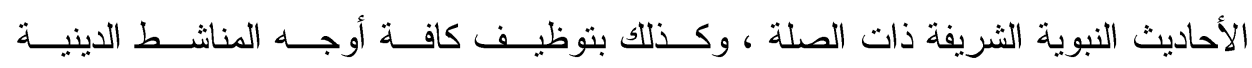
و الاجتماعية في الجامعة ومحيطها الاجتماعي · بل • r- هناك الكثير من القيم الإسلامية المتضمنة للتسامح مثل : العدل و الإحسان ، حُسن الخلق

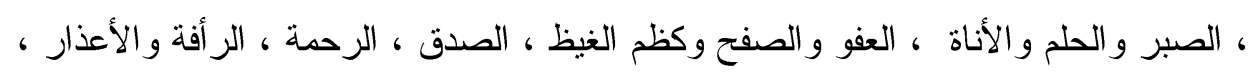

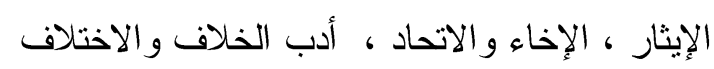




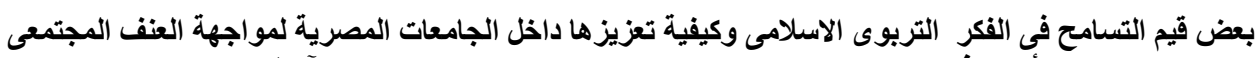
د/ آمال محمد ابر اهيم المهن

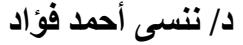

التصور المقترح لدور الجامعات في تعزيز قيم التسامح لمو اجهة العنف المجتمعي انطلاقاً من أهمية الجامعات كحاضنات لهذه الفئة الهامة في التكوين العلمي و المهــاري و القيمي للطلاب وتكوين شخصياتهم ونسقهم القيمي ، لابد للجامعات من الوقوف على دورها في تعميق القيم الفاضلة لدى طلابها ، و التركيز على قيم التسامح بشكل خــاص ، حيـــث أن ولن مسئولية الجامعة هي جملتها دعم ورعاية القيم وتتميتها من أجل بناء مجتمع الغد .

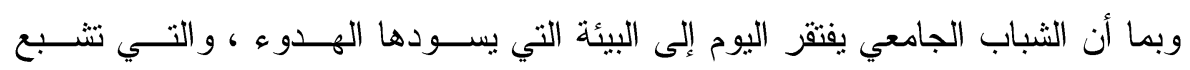

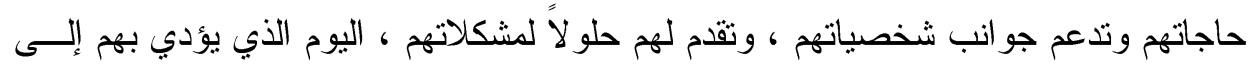
انتهاج علاقات العنف و الكر اهية و التعصب و البغض للناس ، و النفور من المجتمع ( عــوف ، . $(r-r: r \cdot v$

ومن هنا تبدو الأهمية الكبيزة لتحصين الثباب الجامعي برصــيد مــن القــيم الدينيــة

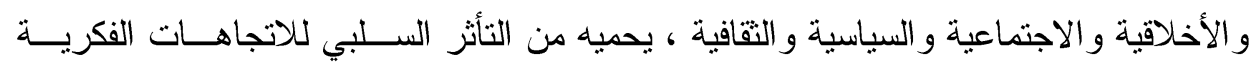
و القيمية التي تطر أ على المجتمع ، لذا لابد من توطيد دعائم هذه القيم بالسلوك الفعلـي مــن قبل : أساتذة الجامعة و الساسة العلماء و المفكرين على مختلف المســتويات لتجســيد القـدوة و المنثل

و على الجامعات أيضناً أن تشيع أجو اء الحوار العقلاني العملي المتسامح مـــع الطلبــة ،

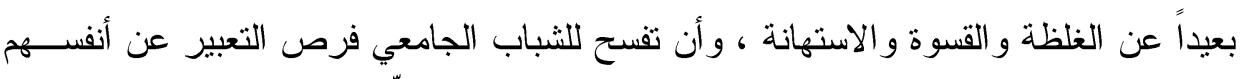

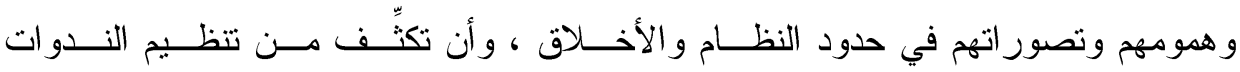
و المحاضرات وورش العمل للتوعية بالقيم وترسيخها بما يخدم واقع المجتمع ويســاهم فـي

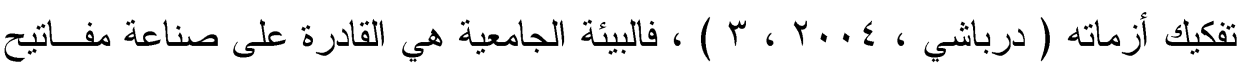
التحضر و التقدم ومحاربة التخلف وأشكال التعصب و العنف و التطرف ، ولعب الدور الأكبـــر

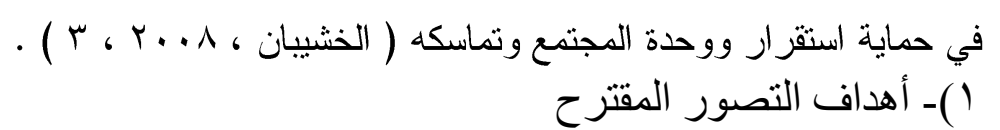

ستقوم الدر اسة بوضع تصور مقترح يهدف إلى تعزيز قيم التسامح لدى طلبتها من خلال المقومات الأساسية للجامعة و المتمثلة في : الإدارة الجامعية ، الهيئـة التذريسـية ، المــنهج الجامعي، الأنشطة الطلابية .

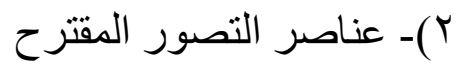
يتكون هذا التصور من عدة أدو ار متر ابطة ، ويمكن أن تُكوّن في النهاية نموذجاً يمكـن الاسترشاد به في بث وتعزيز القيم بصفة عامة للشباب الجامعي وقيم التسامح بصفة خاصة ، وفيما يلي شرح تفصيلي لكل دور: 
بعض قيم التسامح فى الفكر التربوى الاسلامى وكيفية تعزيزها داخل الجامعات المصرية لمواجهة العنف المجتمعى د/ آمال محمد ابر اهيم المنف المجنم

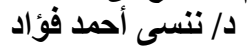

$$
\text { أـ الدور المقترح للإدارة الجامعية }
$$

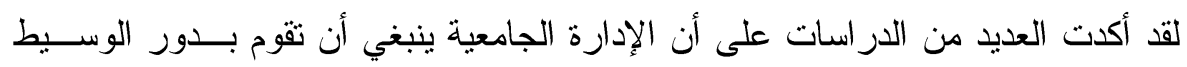

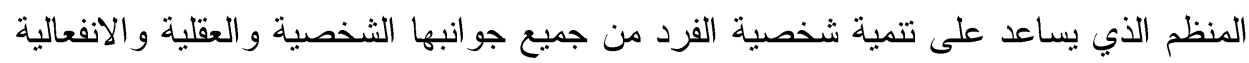

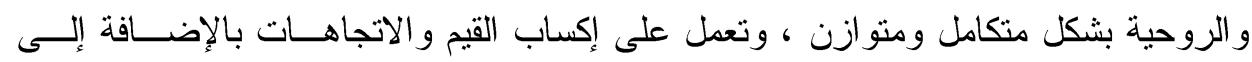

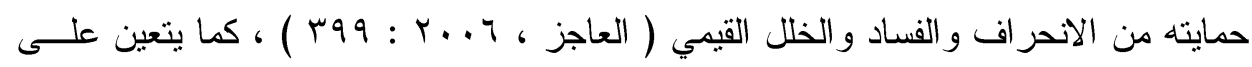

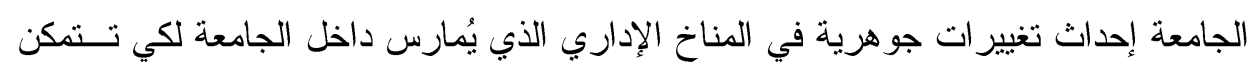

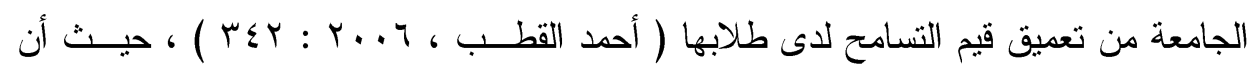

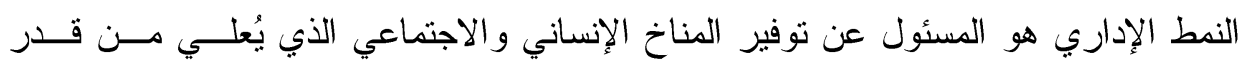

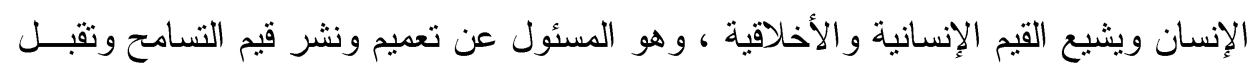

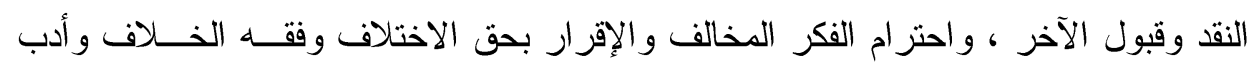

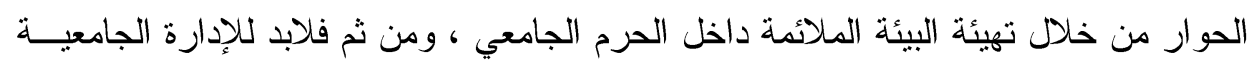

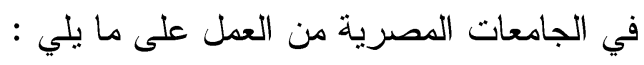
1- إعادة النظر في الأهداف القيمية بإعطائها قدر أكبر من الاهتمام و التركيز ، لتحقيق

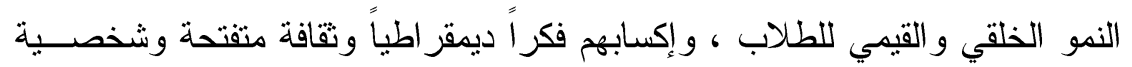

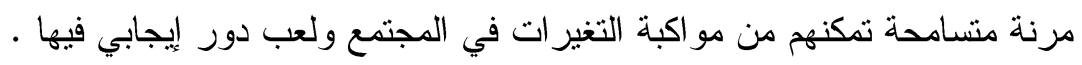

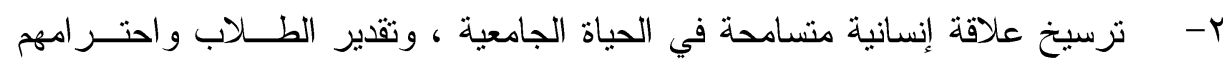

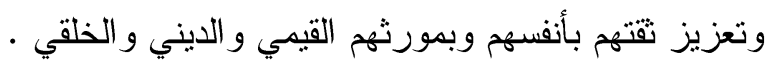

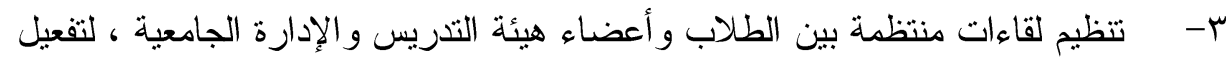

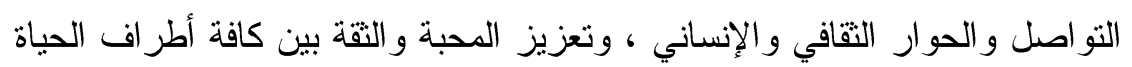

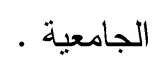
ـ-إعداد مقرر عام لجميع الطلاب بمختلف تخصصاتهم ، يتتاول ثقافة المجتمع وتر اثه الفكري و الوطني والاجتماعي ، ويتضمن هذا المقرر منظومة مــن قـيم التســامح

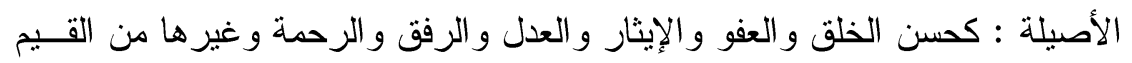

$$
\text { الرفيعة . }
$$

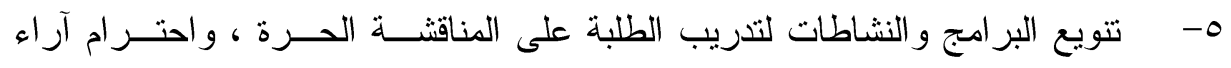

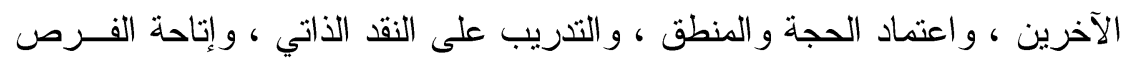

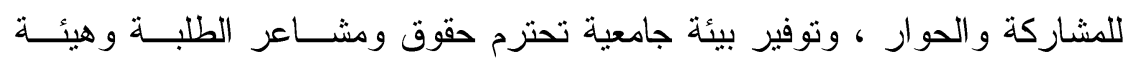
التدريس وتتسم بالتعامل الإنساني الر اقي . 
بعض قيم التسامح في الفكر التربوى الاسلامى وكيفية تعزيزها داخل الجامعات المصرية لمواجهة العنف المجتمعى د/ آمال محمد ابر اهيم المنف المجنم

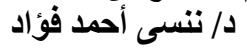

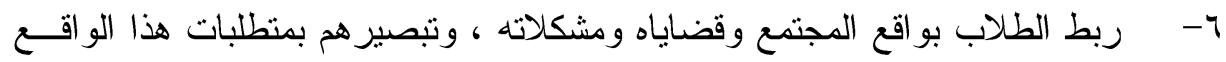

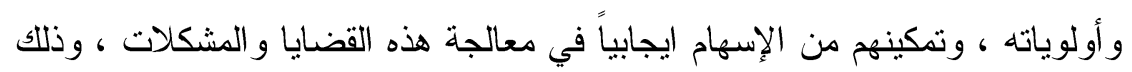

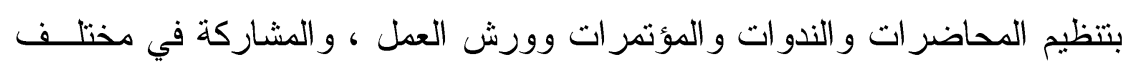

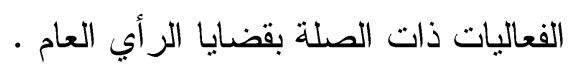

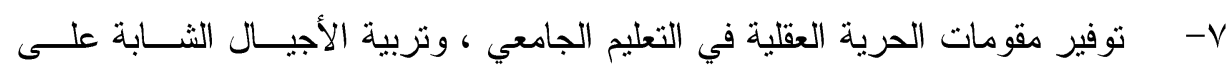

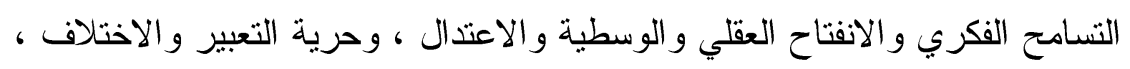

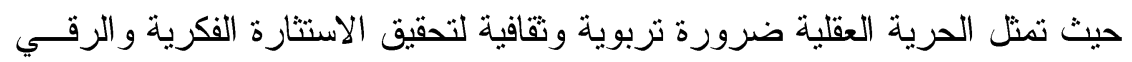

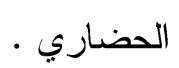

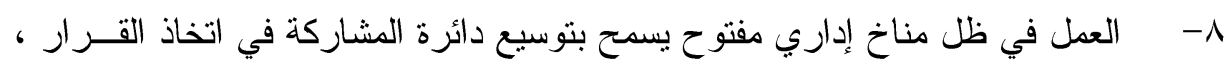

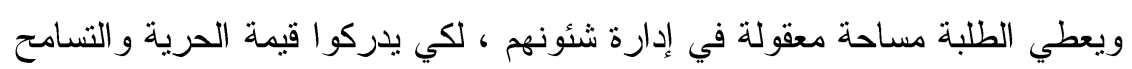

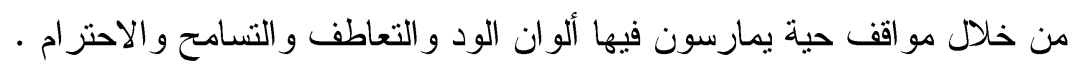

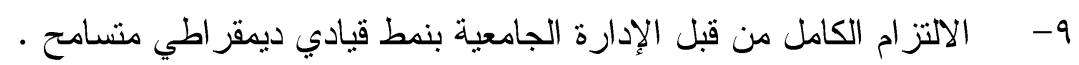

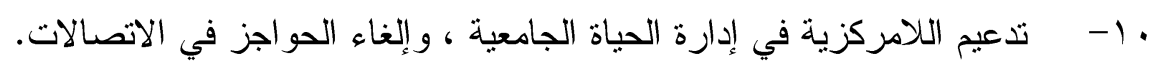

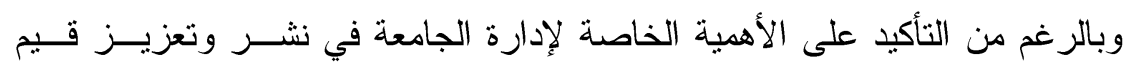

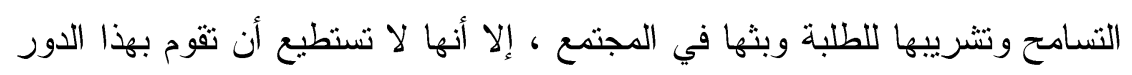

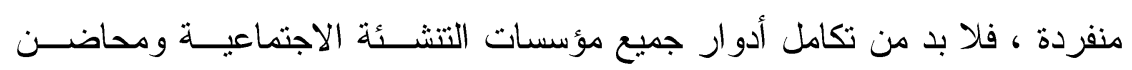

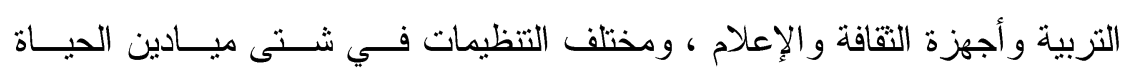

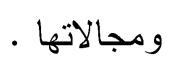

$$
\begin{aligned}
& \text { بـ- الدور المقترح للهيئة التدريسية }
\end{aligned}
$$

الهيئة التدريسية هي الهيئة التي تضم أعضاء هيئة التدريس بالجامعة ، ويعد عضو هيئة

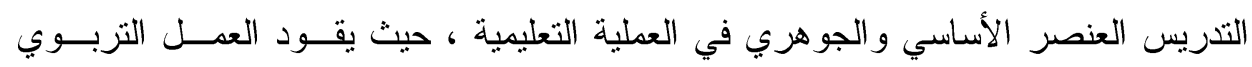

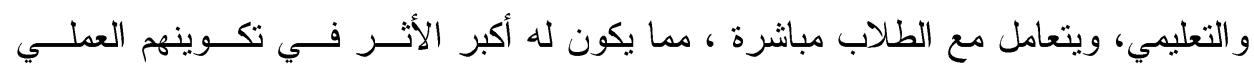

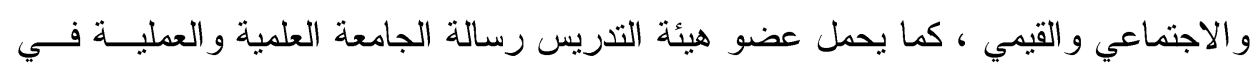

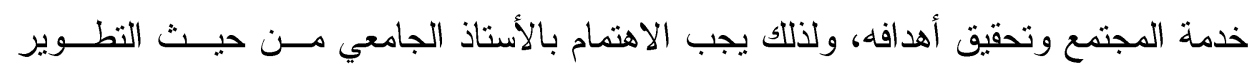
و التقويم

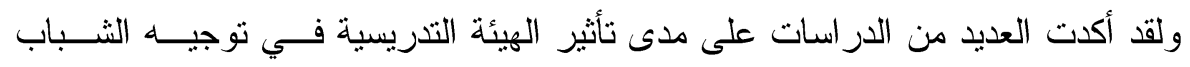

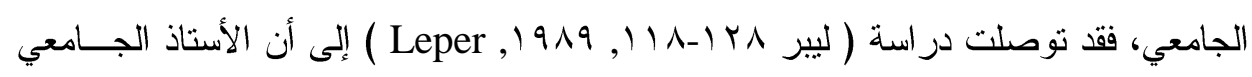

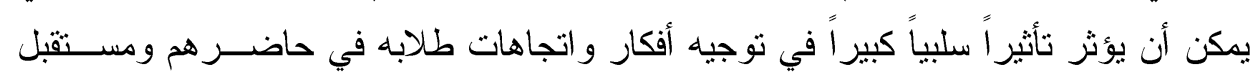

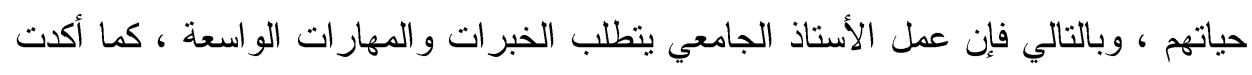


بعض قيم التسامح في الفكر التربوى الاسلامى وكيفية تعزيزها داخل الجامعات المصرية لمواجهة العنف المجتمعى آلمال

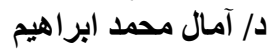

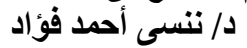

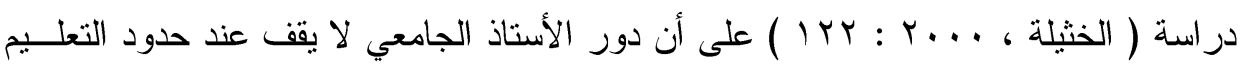
فحسب ، بل ينطلق من السلبيات فيجعل منها إيجابيات ذات أثز مهم في تشكيل الواقع .

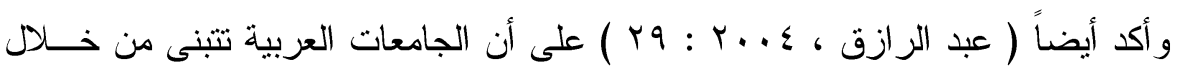
الهيئة التذريسية نظاماً تعليمياً يُرسخ لدى الطالب حفظ المادة العلمية دون تمكينه من الإبداع ،

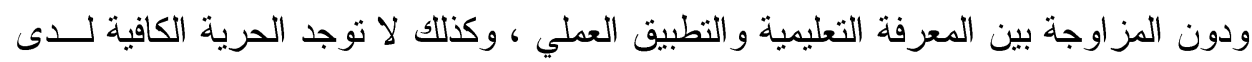

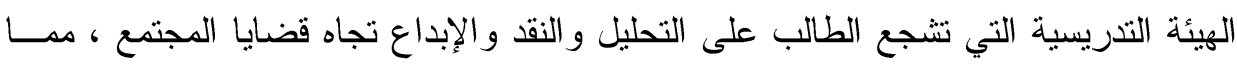
يخلق لديه روح العنف و التعصب و الانغلاق .

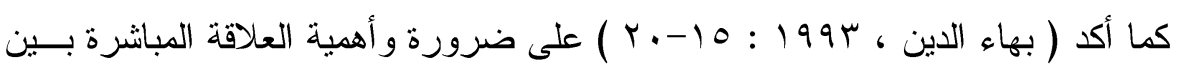
الأستاذ الجامعي والطلاب في تكوين الشخصيات الايجابية الناضجة و المتكاملة لهم ، فبغيـر وجود هذه العلاقة يصبح من العسبر تحقيق الأهداف التربوية والاجتماعية ، وبالتالي هنــاك حاجة ملحة لكي يصبح المناخ الجامعي أكثر ملائمة لتحقيق أهدافه في الثباب الجامعي داخل - المجتمع

يتضح مما سبق أهمية الدور المنوط بالهيئة التدريسية في الجامعة في توجيـهـ الطـلاب وتعديل سلوكهم ، وتتمية القيم الفضلى و المنل الرفيعة لديهم ومنها قيم التسامح ، لذا كان لز اماً على الهيئة التدريسية القيام بالآتي : 1- التحلي بقيم التسامح وبعاطفة قوية نحو هذه القيم ، و التحلي بحب جم للطلبة وللناس وللحياة ، وتجسيد هذه القيم في حياتهم الجامعية و الاجتماعية .

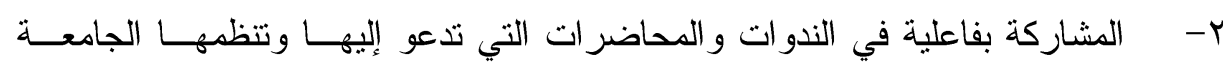
و المؤسسات العامة و الخاصـة ، و التي تتتاول قضـايا القيم ، و التي من شــأنها نشــر ثقافة التسامح ، إلى جانب المشاركة في مختلف الندوات و المؤتمرات و الفعاليات في ولي ولي

$$
\text { · المجتمع }
$$

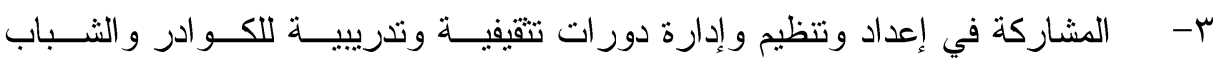

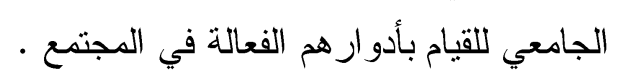

ع- - المشاركة في التخطيط لبر امج التوجيه الديني و القيمي و الخلقي في الجامعة .

0- - الإسهام في توضيح وترسيخ الجانب التطبيقي لقـيم التســامح فـي حيــاة الفــرد

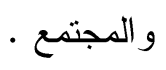

7- لقت نظر الطلاب في حجرة الدر اسة إلى خطورة الأوضلاع القائمة ، و القيم الدخيلــة التي شاعت مؤخراً من الاتجاهات التعنيفية التعصبية ، ليحل محلها التسامح و التآلف 
بعض قيم التسامح في الفكر التربوى الاسلامى وكيفية تعزيزها داخل الجامعات المصرية لمواجهة العنف المجتمعى د/ آمال محمد ابر اهيم المنف المجنم

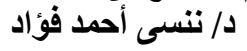

-V

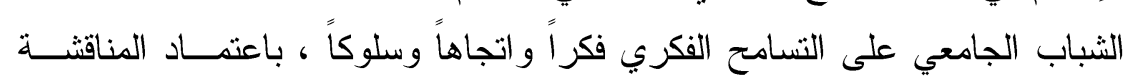

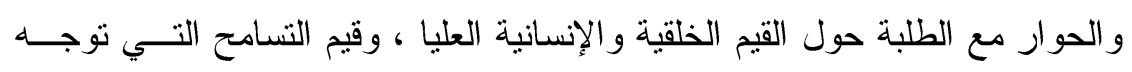
سلوك عامة الناس وخاصتهم في المجتمع توجيهاً صحيحاً. 1- - متوظيف النشاط غير الصفي في تتمية قيم الحرية و التعاون و العمل الجماعي ، و إقامة

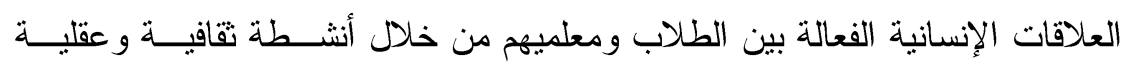
و اجتماعية من شأنها الإسهام في تزبية التسامح الفكري بين الطلاب . 9- تعويد الطلاب على التلقائية وروح الجرأة الأدبية و المبادرة في تقديم الرأي وتبريره

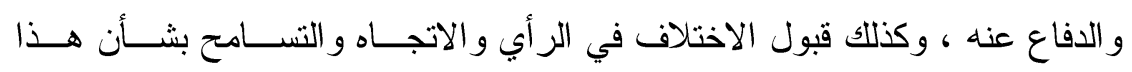

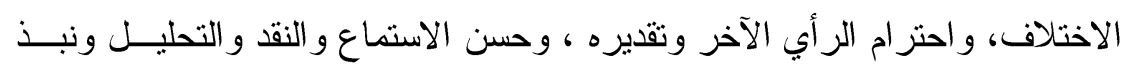

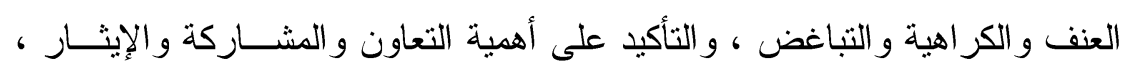
وتبصير هم بمشروعية الاختلاف وقيمته في تجديد الفكر ووضوح الرؤية والوصول إلى الحقيقة . ومن هنا يترتب و اجب وطني و أخلاقي واجتماعي و إنساني علــى الهيئـات التذريسـية

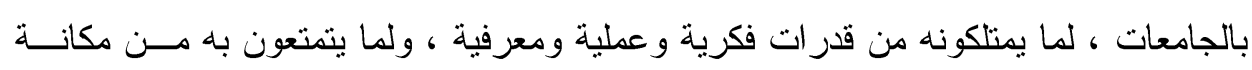

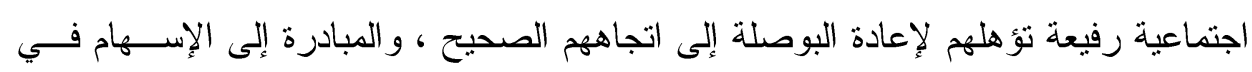

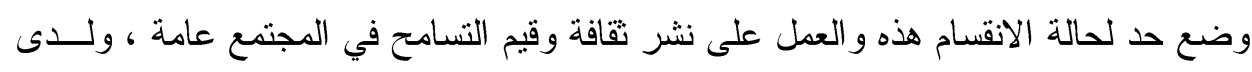

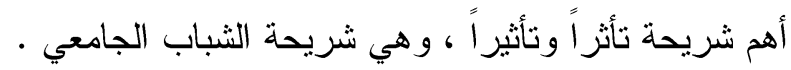
ج- الدور المقتر ح للمنهج الجامعي تمثل المناهج الدراسية البنية المعرفية الأساسية لتعليم الطلاب ، حيث ثقوم على أساسها معظم فعاليات التعليم و التعلم و الأنشطة التعليمية ، من تقاعلات ونقاشــات وقيــاس وتقــويم

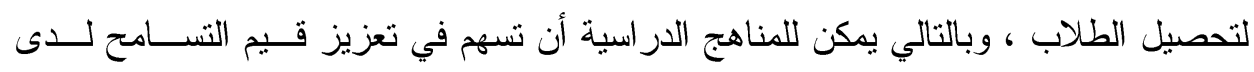
الطلبة ، فالدر اسات الإسلامية و الأدبية والاجتماعية وفروع التربية و العلوم الإنسانية عامــة ، غنية بالموضوعات و المضامين التي تحض على التسامح وتسمو بالنفس إلى مر اتب إعــلاء كر امة الإنسان ، ونبذ الكر اهية و العنف ، وتثير بو اعث العطاء و الإيثار و التعــاون و الصــفح

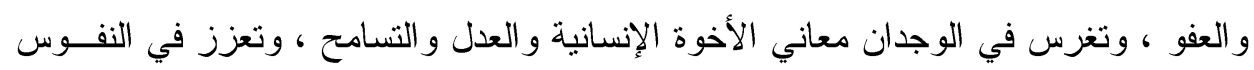
و العقول قيم الديمقر اطية و الوئام و السلام . وبالرغم من الأهمية السامية لدور المنهج الدراسي في تعزيز مختلف القيم عامـــة وقـيم

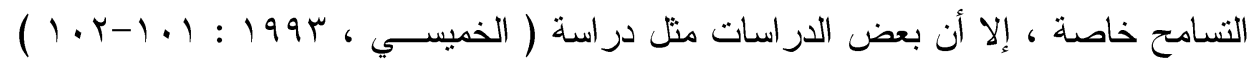


بعض قيم التسامح فى الفكر التربوى الاسلامى وكيفية تعزيزها داخل الجامعات المصرية لمواجهة العنف المجتمعى إلمال

توصلت إلى أن الدراسات الدينية و المقررات الدراسية الإسلامية تحتاج إلى إعادة النظر فـي

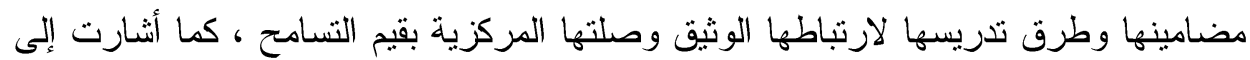

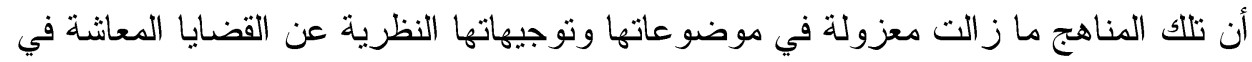

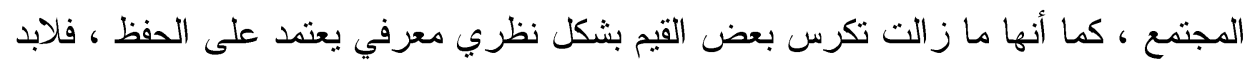
من التركيز على الموضوعات و السير و القصص و السور والآيات القر آنية والأحاديث النبوية

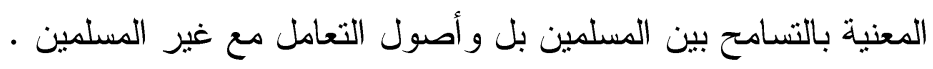

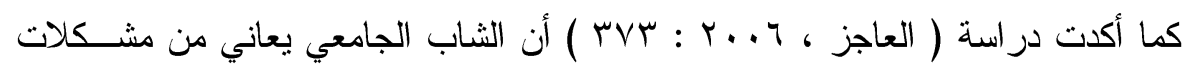

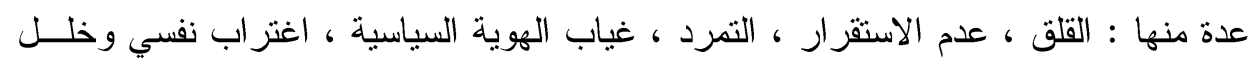

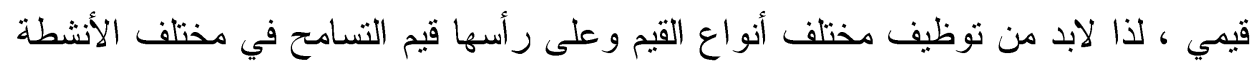

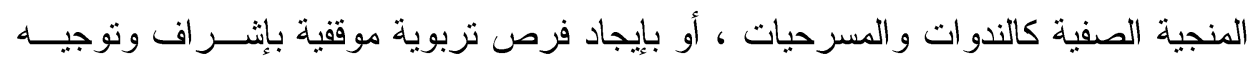

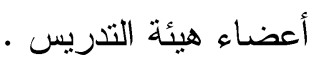

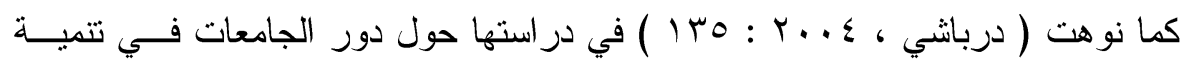

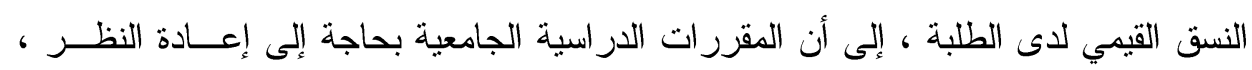

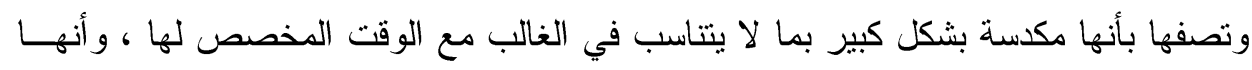

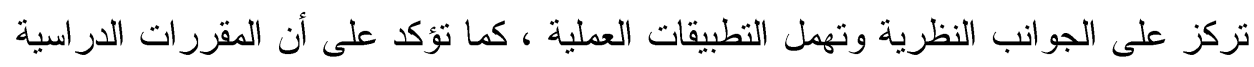

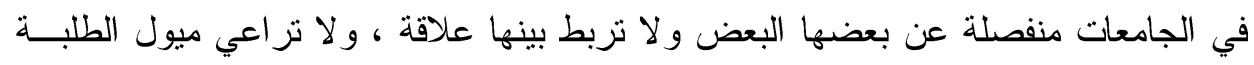

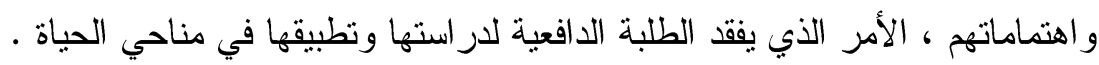

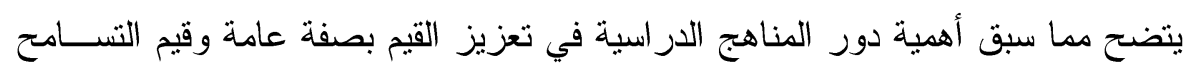

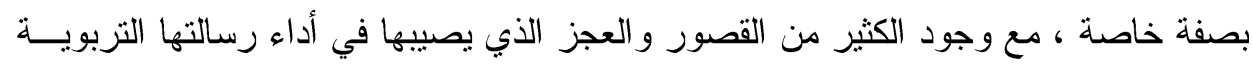

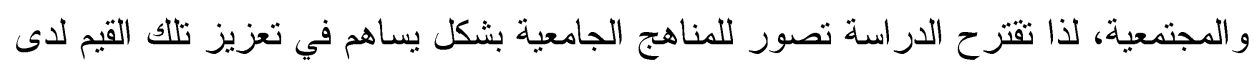
الثباب الجامعي ، ويمكن وضعها في النقاط التالية : ا- برمجة خبر ات و استر اتيجيات تعليمية في مقرر در اســـي بعنـــوان ( المــو اد التعليميــة

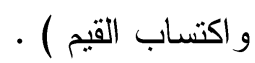

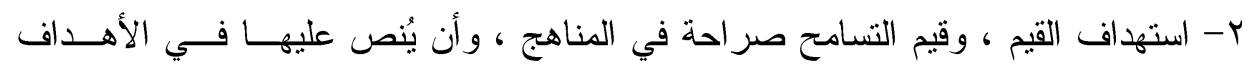

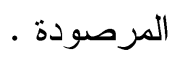
ب- الاعتماد على التعليم التعاوني ، لما يوفزه من تفاعل اجتماعي يؤدي إلى اكتســاب القـيم

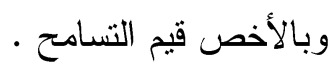
ع - المو اعمة بين الخبرات العلمية ومرحلة النمو الأخلاقي للشباب الجامعي . 
بعض قيم التسامح فى الفكر التربوى الاسلامى وكيفية تعزيزها داخل الجامعات المصرية لمواجهة العنف المجتمعى آمال د/ آمال محمد ابر اهيم المنف المجنم

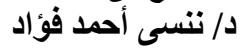

ه- مر اعاة الإطار الزمني المناسب لاكتساب قيم التسامح ، حيث تحتاج تلك القيم إلى أثنـــر

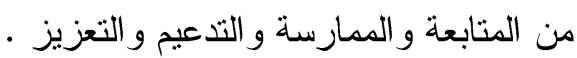

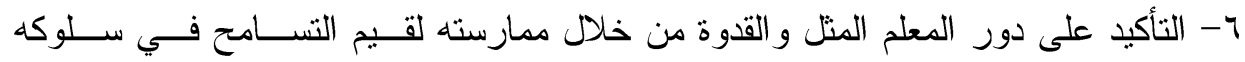
وتفاعلاته المختلفة ، فالتعلم بالقدوة من أكثر الاستر اتيجيات سهولة وأبلغها أثراً.

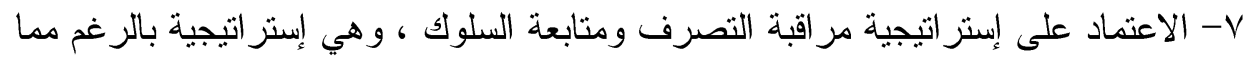
تتصف به من صعوبة إلا أنها مناسبة ومجدية في حقل القيم .

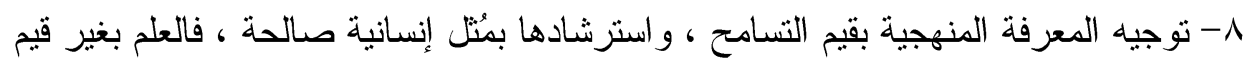

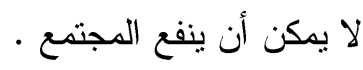

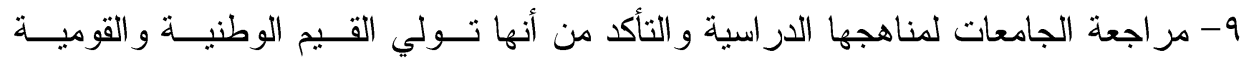

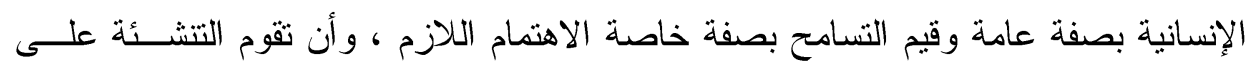

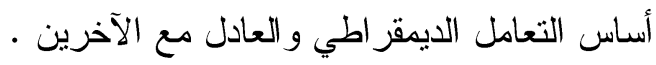

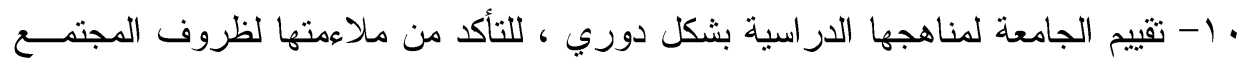
ومو اكبتها لما يُستجد من العلم و المعرفة .

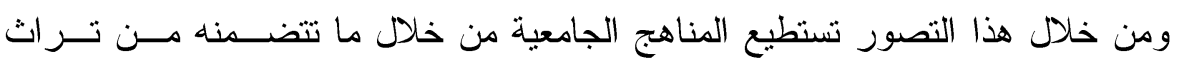

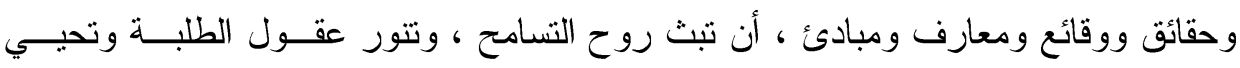

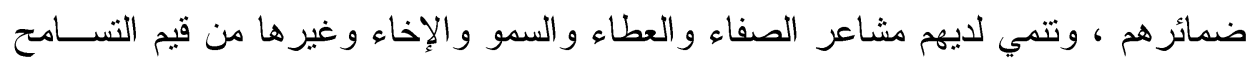
النيلة .

\section{د- الدور المقتر ح للأنشطة الطلابية}

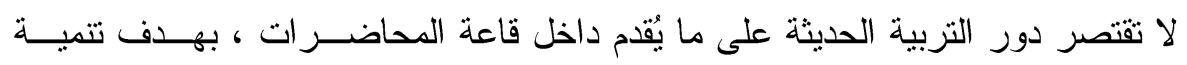

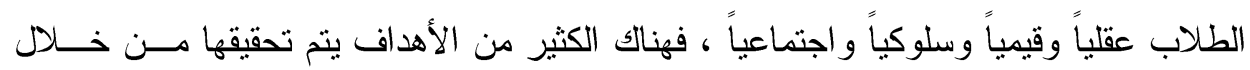
الأنشطة الطلابية التلقائية التي يمارسها الطلاب داخل الجامعة ، ولهذه الأنشطة إمكانية كبيرة

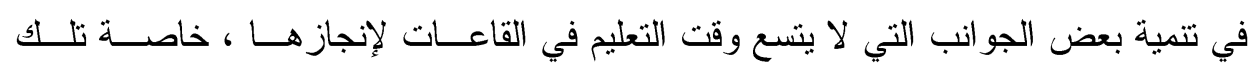

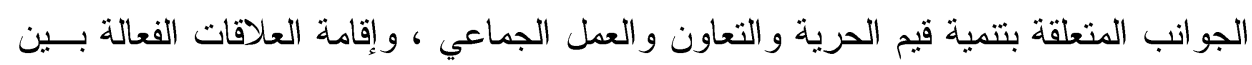

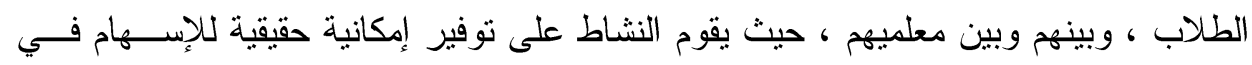

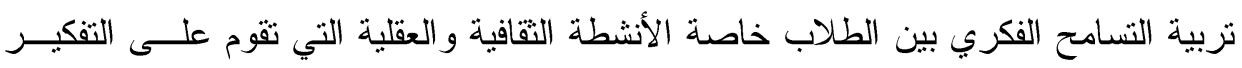

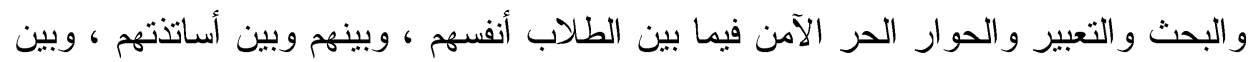

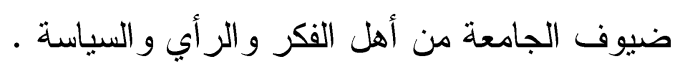

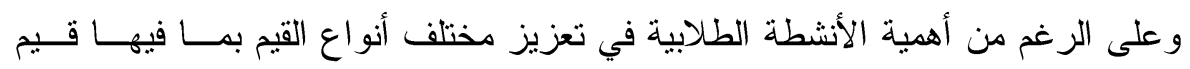

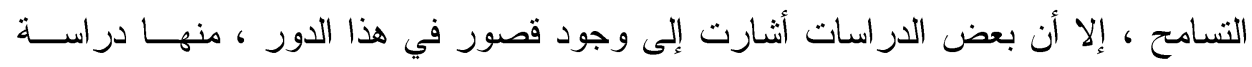


بعض قيم التسامح في الفكر التربوى الاسلامى وكيفية تعزيزها داخل الجامعات المصرية لمواجهة العنف المجتمعى آلمال

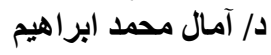

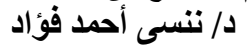

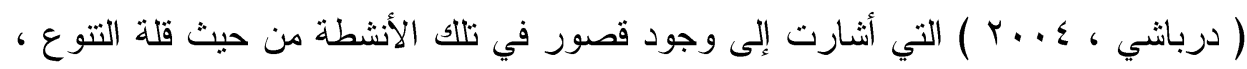

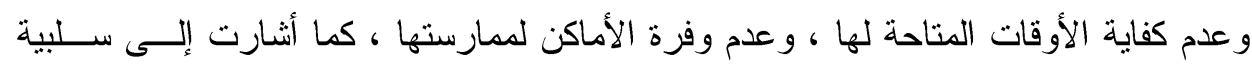

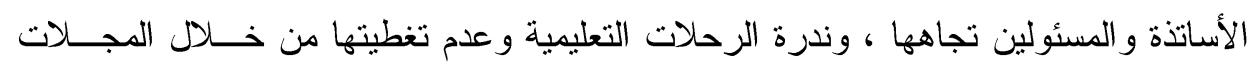

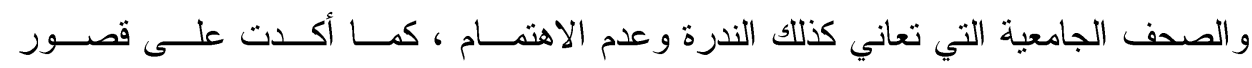

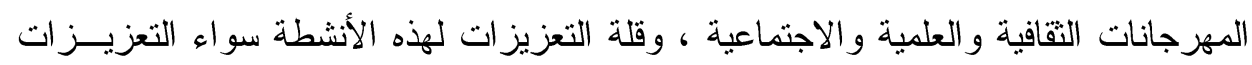
المادية أو المعنوية .

ومن ثم تقترح الدراسة الحالية تصور للأنشطة الطلابية داخل الجامعة لتساهم في تعزيز

قيم التسامح لدى الثباب الجامعي ، ويمكن وضعه في النقاط النالية :

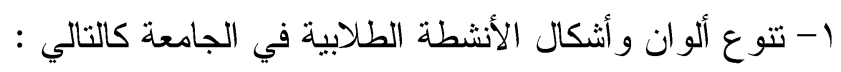

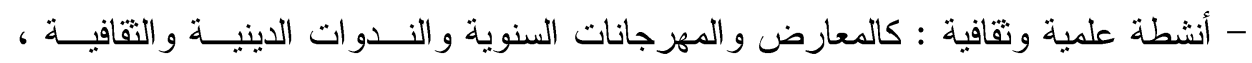

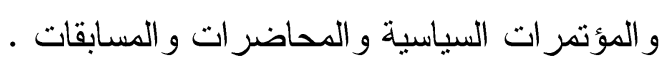

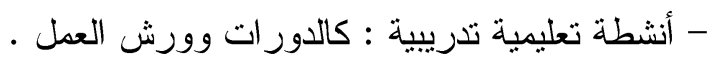

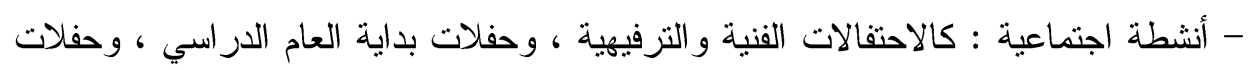

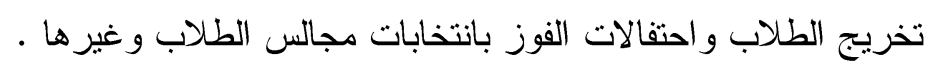

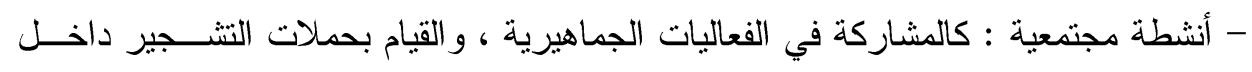

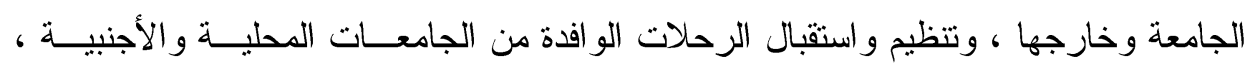

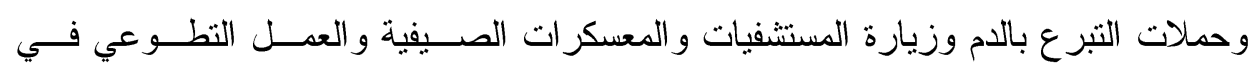

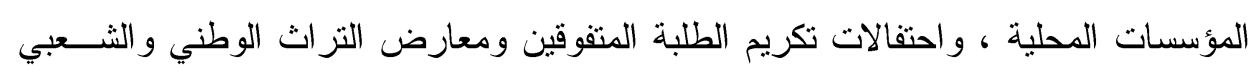
و غير ذلك .

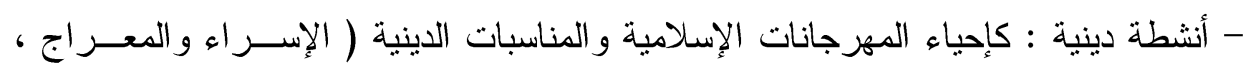

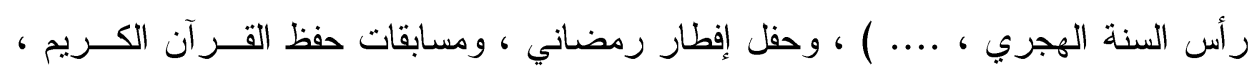
وعمل مجلات دينية ونشرات وندوات تتتاول القضايا الإسلامية المختلفة .

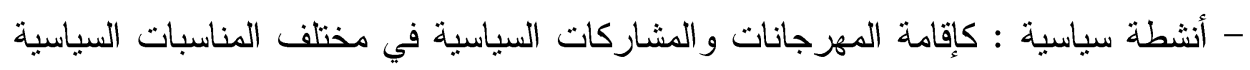

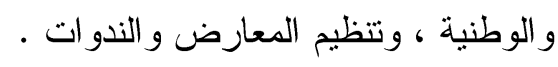

- أنشطة رياضية ورحلات : كإقامة مختلف المسابقات الرياضية ( كرة القدم - كرة السلة -

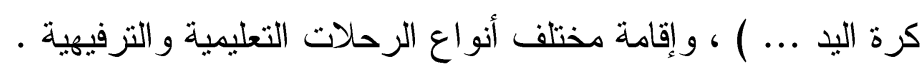

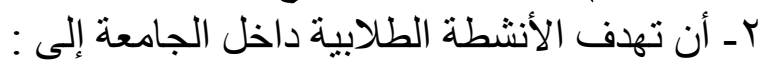

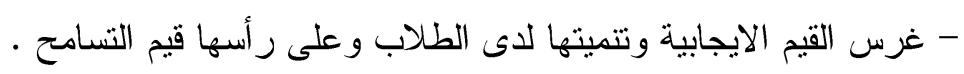


بعض قيم التسامح في الفكر التربوى الاسلامى وكيفية تعزيزها داخل الجامعات المصرية لمواجهة العنف المجتمعى آمال

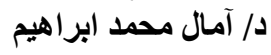

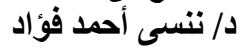

- تدريب الطلاب على ممارسة الديمقر اطية في الانتخابات ، و التخطيط و التنفيـــــ والتـــابير

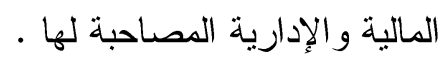

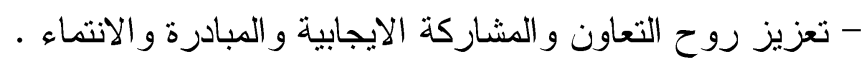

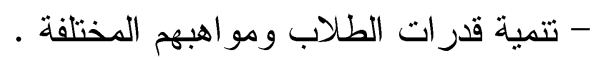

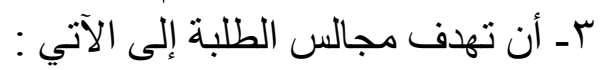
- تعميق التزام الطلبة بقضاياهم العامة وترسيخ قيم الانتماء و التسامح لديهم.

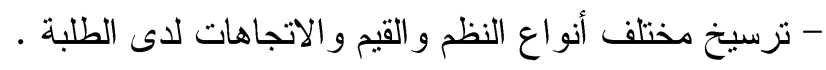

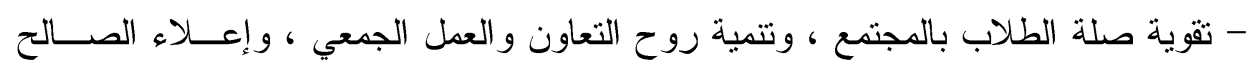
العام - مشاركة الطلاب الواسعة في صياغة القرارات وتتفيذها و التعامل الحضـاري القـائم علـى الحى

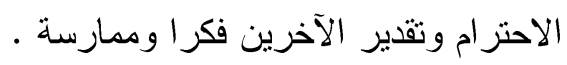

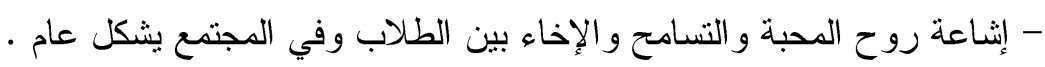

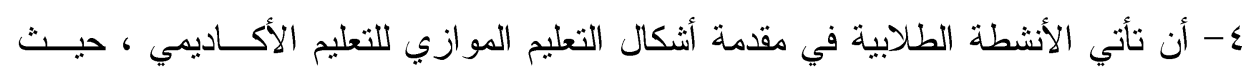

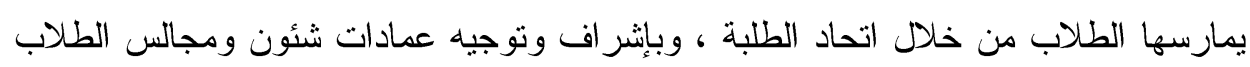

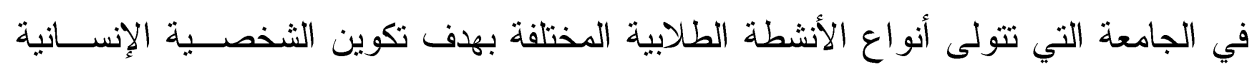

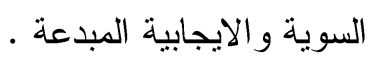

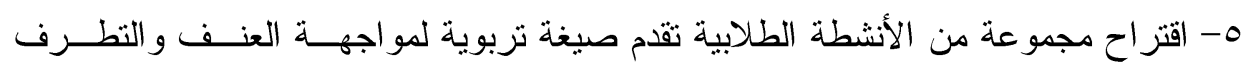

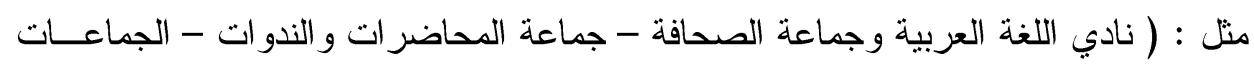

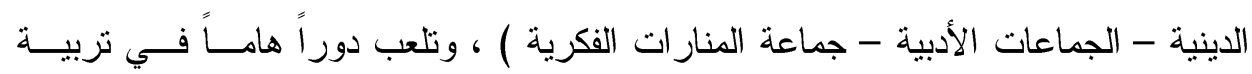

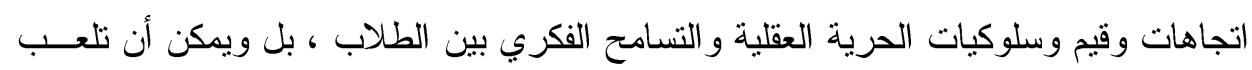

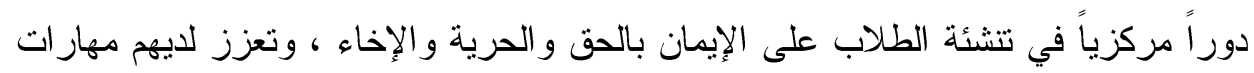

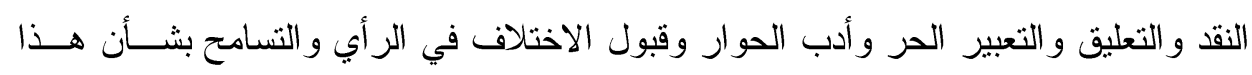

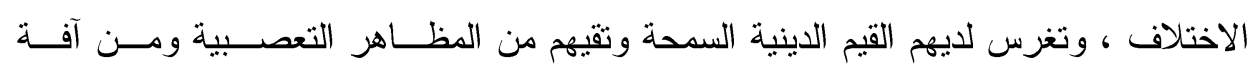
الانغلاق الفكري وما يتبعه من سلوكيات عنيفة . توصيات الدر اسة الفئة

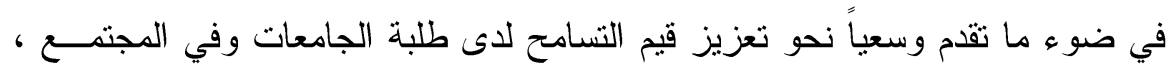

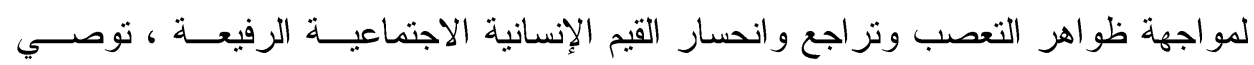

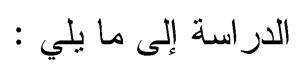




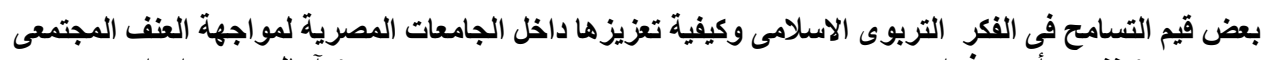

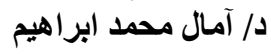

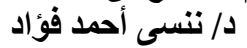

1- - تقديم الأسس العلمية للتصدي للمشكلات التي تو اجه الشباب الجامعي وفي مقـدمتها أزمة القيم وبلبلة الأفكار وحرب الأيديولوجيات و الاستقطابات الفكريــة و السياسـية وية الحادة التي يعاني منها الثباب عامة و الجامعيين منهم خاصة . ץ- - إثـاعة مناخ تسامحي داخل الجامعة وذلك بانتهاج نمط إداري تســامحي وترســيخ احتر ام كر امة الطلبة وتفعيل أجو اء التو اصل و الحو ار الحضاري داخل الجامعة وفي

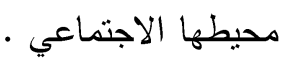
r- تضمين المناهج و المقررات الدراسية المزيد من المواد و المسابقات الغنية بمضامين

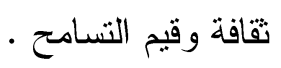
توجيه و إجر اء الأبحاث العلمية و التربوية المرتبطة بثقافة وقيم التسامح ودعمهـــا

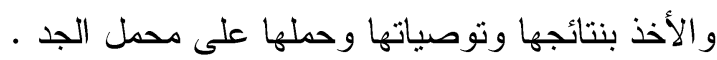

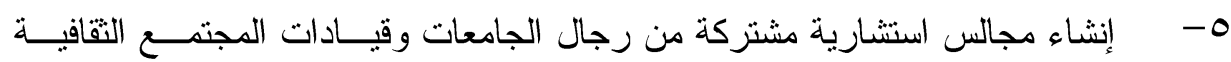
و السياسية و علماء الدين ، لنشر وتعزيز قيم وثقافة التسامح في المجتمع ·

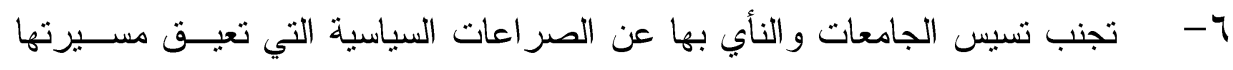
وتحرفها عن وجهتها ووظائفها الأساسية .

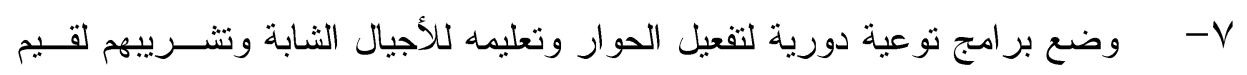

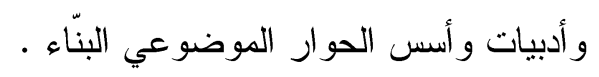

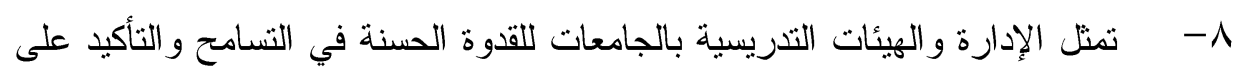
دور التعليم بالقدوة . مقتر حاث الدر اسة دورة 1- - إجر اء المزيد من الدراسات و الأبحاث العلمية لمعالجة ظواهر التعصــب و العنـــ المجتمعي و الانغلاق العقلي و التطرف وتتامي هذه الظو اهر في المجتمع .

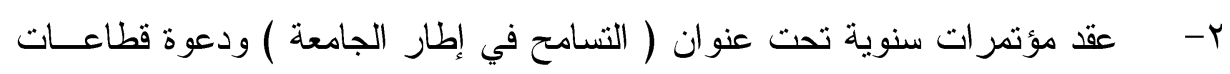
المجتمع للمشاركة فيها و الإفادة بهدف ترسيخ قيم وثقافة التسامح في المجتمع . س- - إصدار دورية فصلية أو شهرية أو مجلة تحمل عنوان ( التسامح في الجامعــة ) ، و العمل على نشرها عبر شبكة الانترنت على موقع الجامعة .

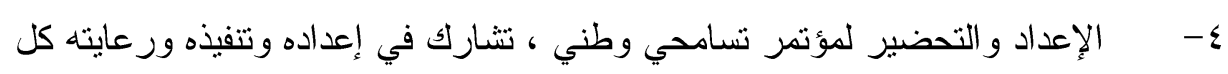
الجامعات المصرية ، بهدف إعادة الوحدة ولم شمل المجتمع وفئاته المتتافرة . 0 - تزيين مداخل الجامعات ومحيطها وطرقها وقاعاتها بلافتات وملصقات تدعو إلــى

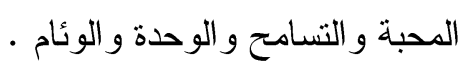


بعض قيم التسامح في الفكر التربوى الاسلامى وكيفية تعزيزها داخل الجامعات المصرية لمواجهة العنف المجتمعى

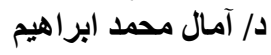

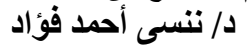

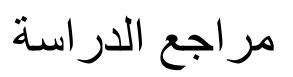

ا. ابن أبي الدنيا ، أبو بكر عبد الله بن محمد بن عبيـــ ( . 199 ) : مكـــارم الأخــلاق ، تحقيق : مجدي السيد إبر اهيم ، مكتبة القرآن ، القاهرة .

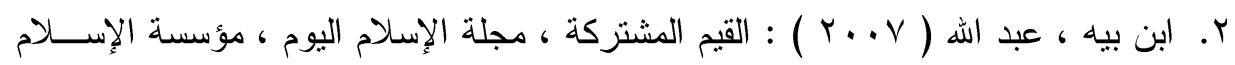

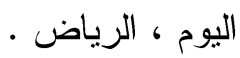

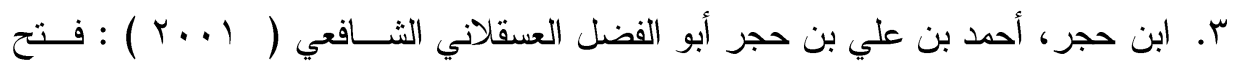
الباري شرح صحيح البخاري ، تحقيق : عبد القادر شيبة الحمد ، دار المعرفة، بيروت.

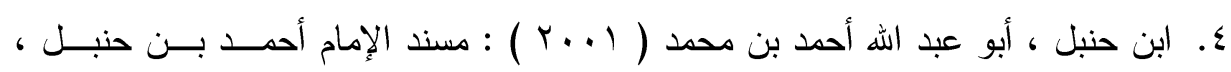
تحقيق : شعيب الأرنؤوط وآخرون ، إثراف : عبد الله عبد المحسن التركي ، مؤسسة

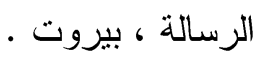
ه. ابن فارس ، أبو الحسن ( 9 ( ) ) : معجم مقاييس اللغة ، المجلد الثالث ، طץ ، تحقيق عبد السلام محمد هارون ، دار الجبل ، بيروت . 7. ابن فتوح ، محمد بن أبي نصر فتوح بن عبد الله بن فتـوح بـن حميــد ( 1990 ) ) :

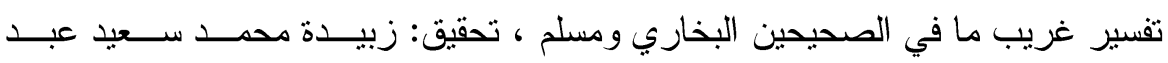
العزيز، مكتبة السنة، القاهرة . V. ابن قيم الجوزية ، محمد بن أبي بكر بن أيوب ( 1991 ) : إعلام الموقعين عـن رب مبر العالمين ، تحقيق : محمد عبد السلام إبر اهيم ، دار الكتب العلمية ، بيروت . ^. ابن ماجه ، أبو عبد الله محمد بن يزيد القزويني ( 1991 ) : سنن ابن ماجه ، تحقيق : بشار عو اد معروف ، مكتبة أبي المعاطي ، القاهرة . 9. ابن مالك ، مالك بن أنس بن عامر الأصبحي ( ع . . ؟ ) : الموطأ ، مؤسسة زايد بـن سلطان آل نهيان للأعمال الخيرية والإنسانية ، أبو ظبي ، الإمارات .

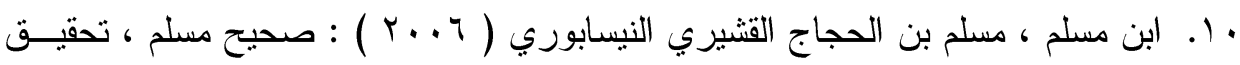

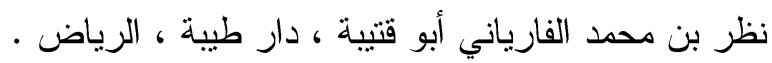
ا ا. ابن منظور ، محمد بن مكرم الأفريقي المصري ( 1907 ) : لسان العرب ، دار صادر

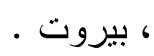

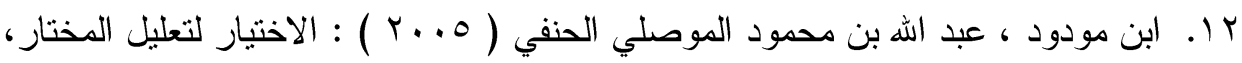
تحقيق : عبد اللطيف محمد عبد الرحيم ، طس ، دار الكتب العلمية، بيروت .

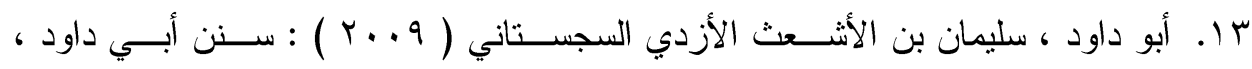
تحقيق : شعيب الأرنؤوط و آخرون ، دار الرسالة العالمية ، بيروت . 


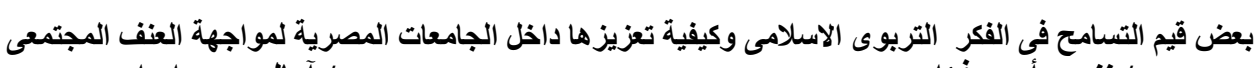

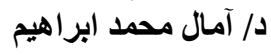

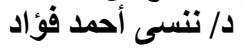

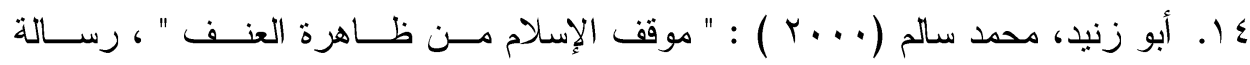

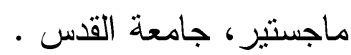
1. أبو عجوة ، محمد نجيب ( . . . . : المجتمع الإسلامي دعائمه و آدابه في ضوء القرآن ، مكتبة مدبولي ، القاهرة .

7 ا. أبو ليلى ، فرج محمود ( 1999 ) : الإسلام وبناء المجتمع ، الأرز، لبنان.

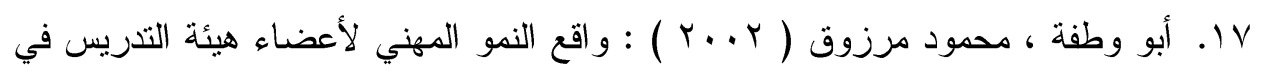
الجامعة الإسلامية وسبل تطويره من وجهة نظرهم ، المكتبة المركزية ، غزة .

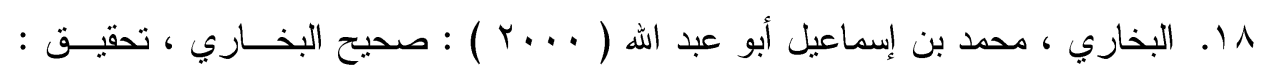
محمد زهير بن ناصر الناصر ، دار طوق النجاة .

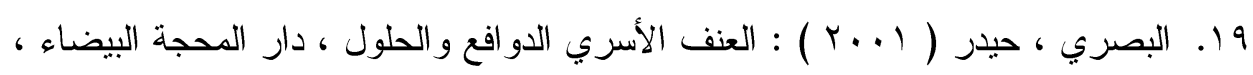
لبنان •r. البكوشي ، ناجي ( 1990 ) : " التسامح عماد حقوق الإنسان " ، المجلة العربية لحقوق

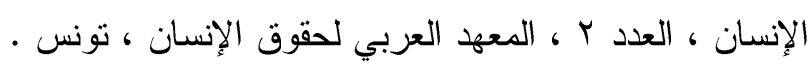

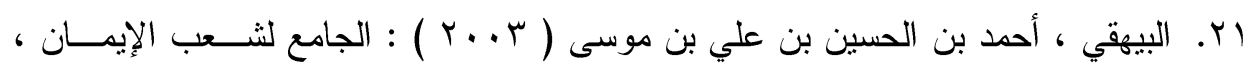
تحقيق : مختار أحمد الندوي وعبد العلي عبد الحميد حامد ، مكتبة الرشد . r r. الترمذي ، محمد بن عيسى بن سورة بن موسى بن الضحاك ( 1997 ) : سنن الترمذي

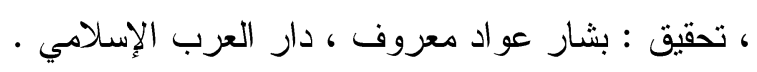

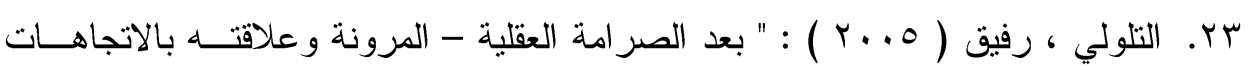

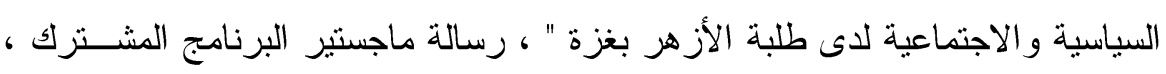
كلية التزبية بجامعة عين شمس ، القاهرة ، كلية التزبية بجامعــة الأقصــى ، غــزة ،

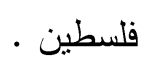

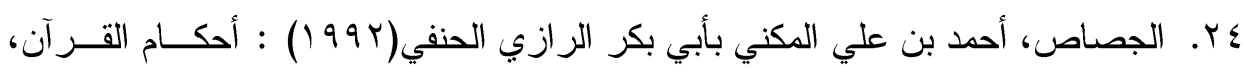
تحقيق : محمد الصادق قحاوي ، دار إحياء الكتب العربية ، القاهرة. هr. الجليل ، سمير ( r 199 ) : التسامح في اللغة العربية ، منشور ضمن كتاب التشــامح

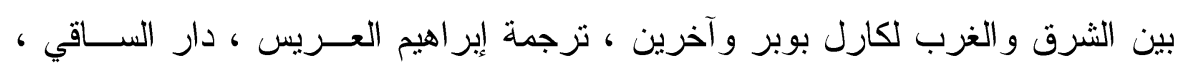
بيروت

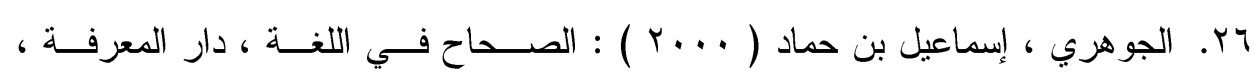
بيزوت 
بعض قيم التسامح في الفكر التربوى الاسلامى وكيفية تعزيزها داخل الجامعات المصرية لمواجهة العنف المجتمعى آلمال د/ آمال محمد ابر اهيم المنف المجنم

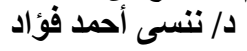

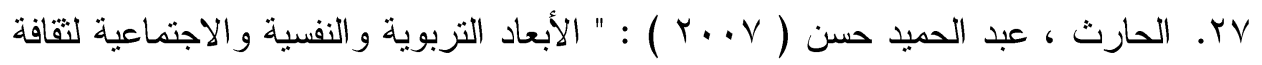

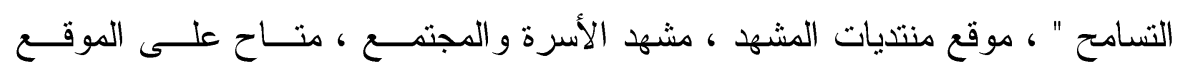

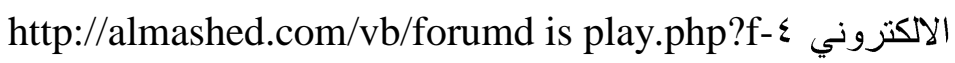
^r. الحاكم ، محمد بن عبد الله النيسابوري ( r . . r ) : المستدرك على الصحيحين ، تحقيق مصطفى عبد القادر عطا ، دار الكتب العلمية ، بيزوت .

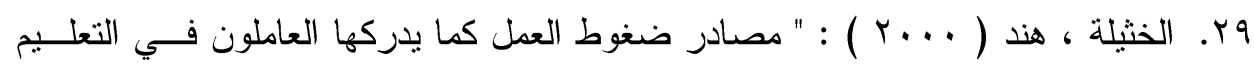
الجامعي " ، مجلة الملك سعود للعلوم التربوية والدراسات الإسلامية ، جدة ، المملكــة

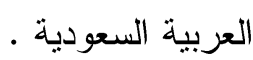
• ". الخشيبان ، علي بن حمد ( ^ . . r ) : " جامعاتتا هل تقدم خدمة المجتمع ؟ " ، جريــدة

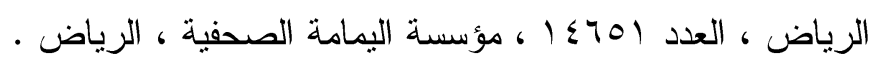

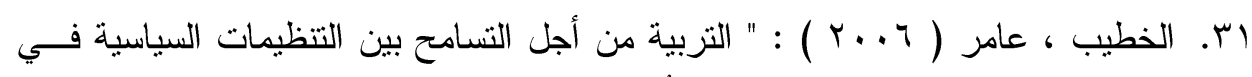
المجتمع الفلسطيني " ، در اسة نظرية قُمت للمؤتمر الشعبي من أجل نشــكيل حكومـــة

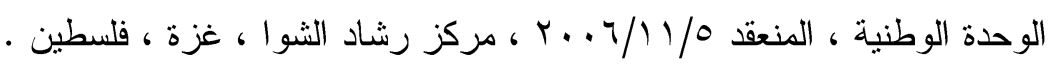

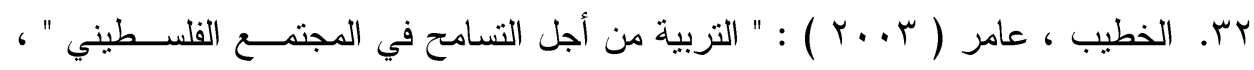
بحث مقدم للملتقى الفكري الثالث للمسلمين و المسيحيين الفلسطينيين ، المنعقد في الفتـرة من ع-7 مارس ب . . r ، قاعة المؤتمرات بجمعية الهلال الأحمر الفلسطيني ، غـزة ، فلسطين من مل سس. الخميسي ، السيد سلامة ( س991 ) ) : " تربية التسامح الفكري - صيغة تربوية مفترحة لمو اجهة التطرف " ، سلسلة أبحاث تصدر عن رابطة التزبية الحديثـة ، العـدد جب ، 6 السنة العاشرة ، دار المعرفة الجامعية ، الأزاريطة ، الإسكندرية .

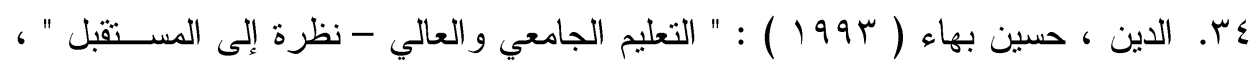
مجلة العلوم التربوية ، المجلد الأول - العدد الأول ، القاهرة . هـ. الرازي ، محمد بن أبي بكر ( . . . . ) : مختار الصحاح ، دار الحديث ، القاهرة .

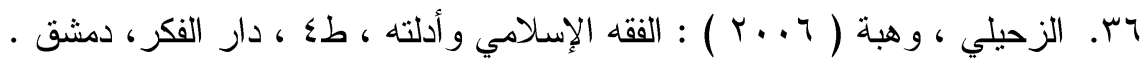

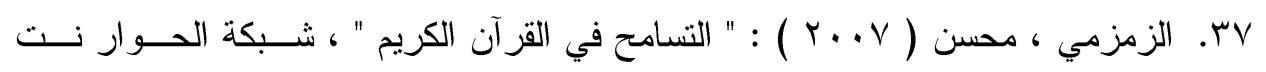

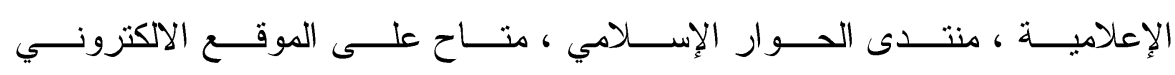
http://www.alhiwar.net ^ז. الزيان ، رمضان و آخرون ( r . . ) ) : محاضرات في الثقافة الإسلامية ، مطبعة دار

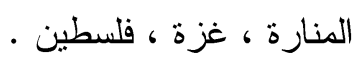


بعض قيم التسامح في الفكر التربوى الاسلامى وكيفية تعزيزها داخل الجامعات المصرية لمواجهة العنف المجتمعى آمال

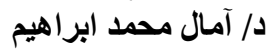

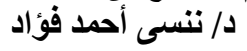

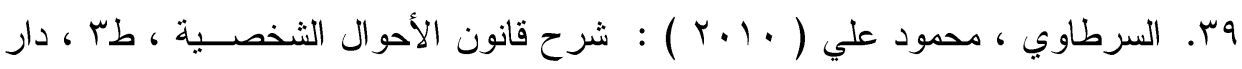

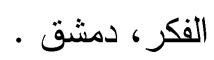

•ـــ الصنعاني، محمد بن إسماعيل الأمير الكحلاني (.97 (197) : سبل السلام ، ط؛ ، مكتبــة

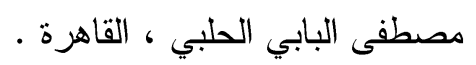

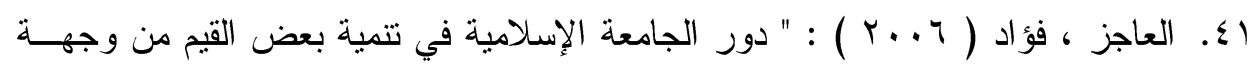

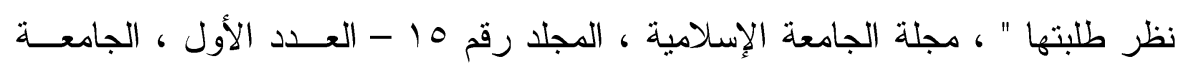

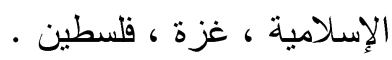

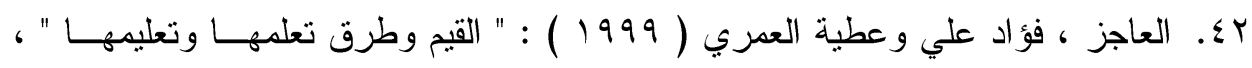

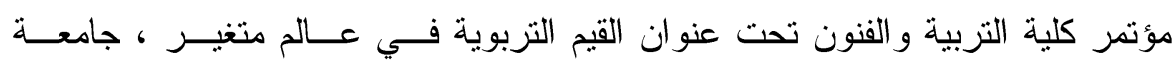
اليرموك .

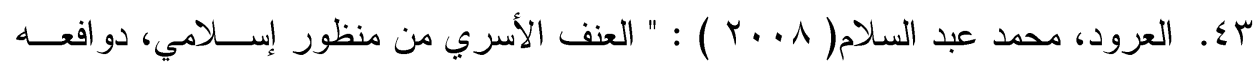

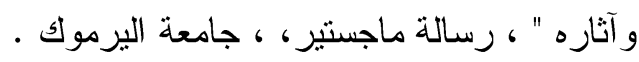

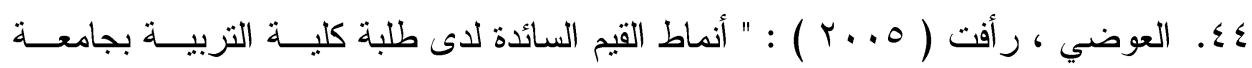

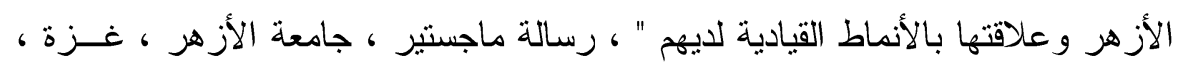
فلسطين - فالاز و

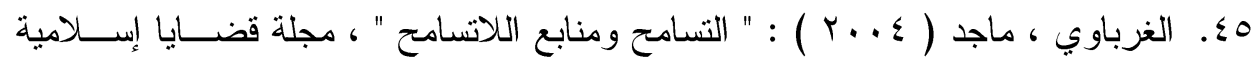

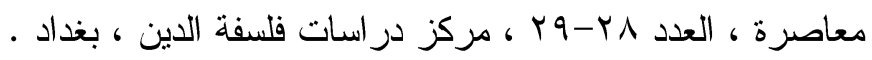

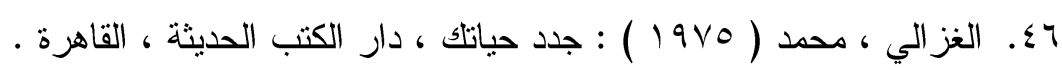

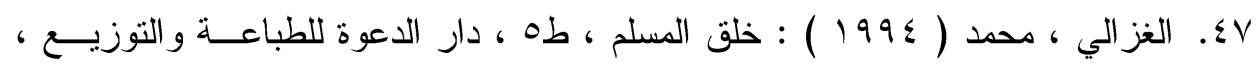
الإسكندرية .

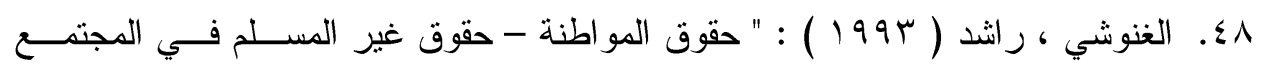

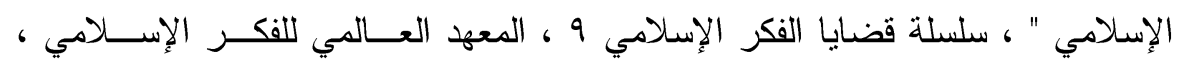

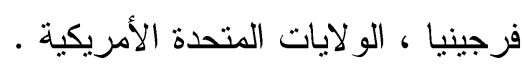

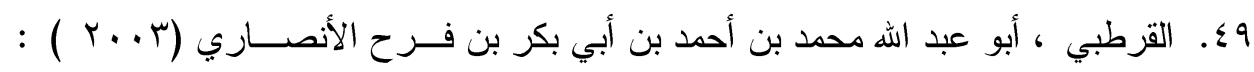

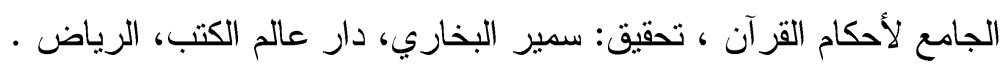

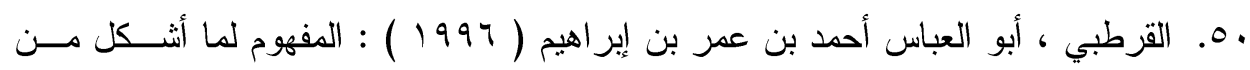

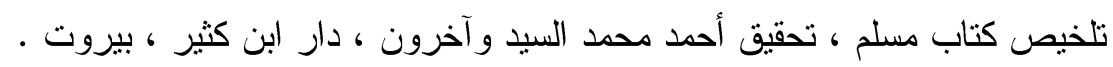

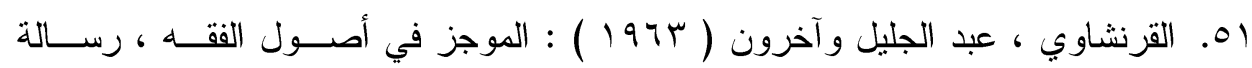

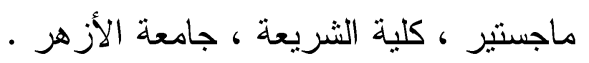




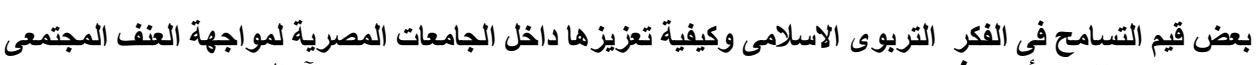

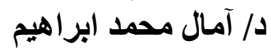

د/ نتسى أحمد فؤاد الدي

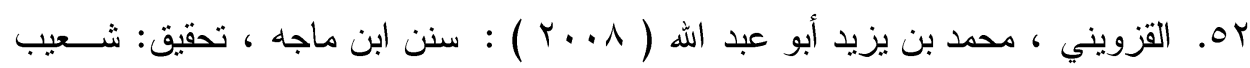
الأرنؤوط و آخرون ، دار الرسالة العالمية ، بيروت.

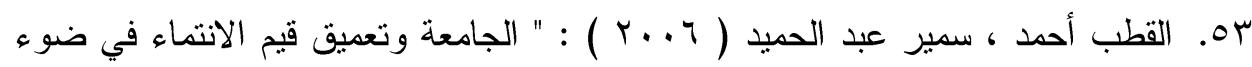
معطيات القرن الحادي و العشرين " ، مجلة كلية التربية ، جامعة المنصــورة ، العــدد . 7 .

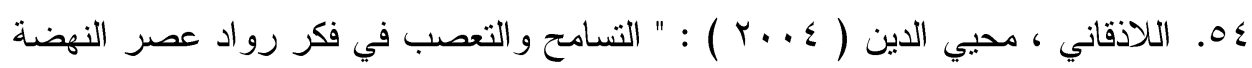

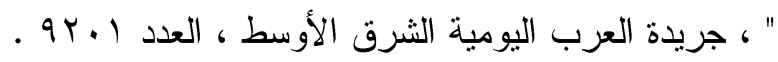

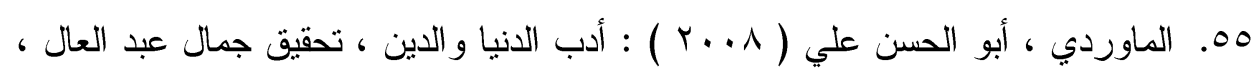
مكتبة عباد الرحمن ، المنصورة .

1. المجلس القومي للتعليم و البحث العلمي و التكنولوجيا ( ب99 1 ) : " تأصيل القيم الدينيــة

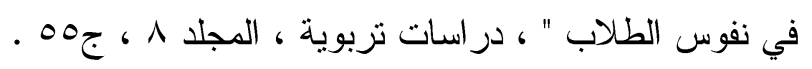
V. V. المخاريز، لافي صالح مقبل (T . r ) : " ظاهرة العنف الطلابي في الجامعات الأردنية

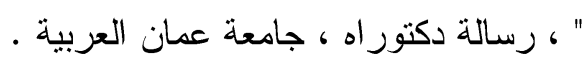

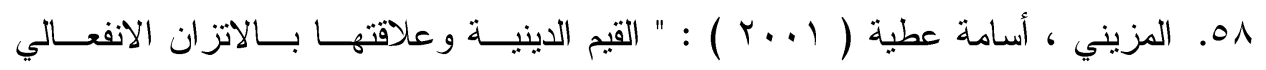
ومستوياته لدى طلبة الجامعة الإسلامية بغزة " ، رسالة ماجستير ، كلية التزبية بالجامعة

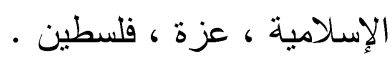
9. المصعبي ، عبد الملك منصور ( V. . . . ) : الحوار مع الآخر تذليل العوائق و التحديات

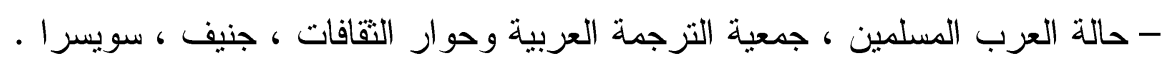

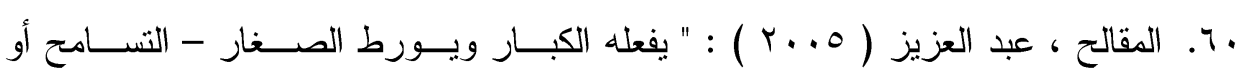
الانقر اض " ، مجلة المعرفة الأرشيفية ، العدد اب إ ، صنعاء ، اليمن .

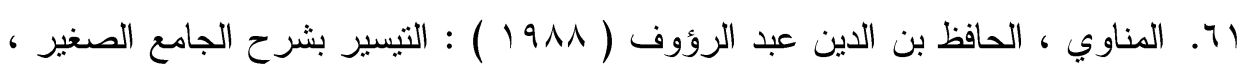
طس ، مكتبة الإمام الثافعي ، الرياض •

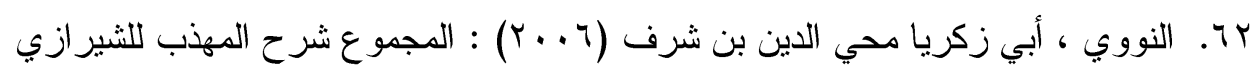
، عالم الكتب ، السعودية .

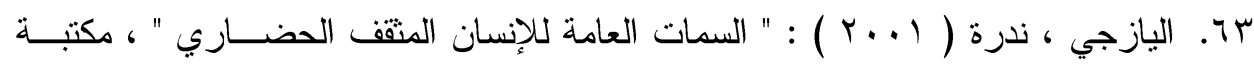

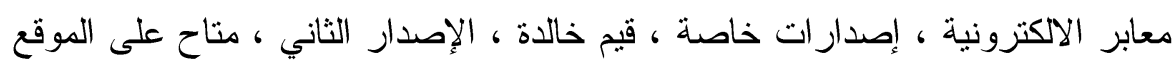
http://www.maaber.org الالكتروني

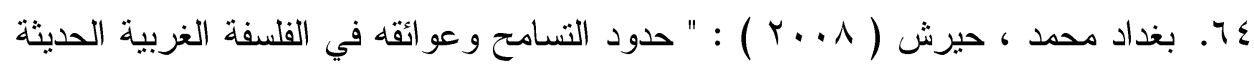
" ، مجلة علوم إنسانية ، السنة الخامسة ، العدد بس ، تونس . 
بعض قيم التسامح في الفكر التربوى الاسلامى وكيفية تعزيزها داخل الجامعات المصرية لمواجهة العنف المجتمعى

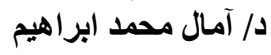

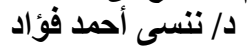

ه7. بيز اني ، ادجار ( (999 ) ) " في مواجهة عدم التسامح " ، رسالة اليونسكو ، يونيــو - $) 99 r$

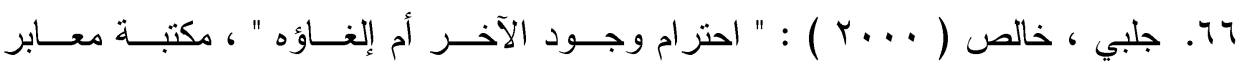

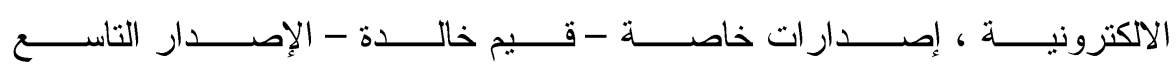
http://WwW.maaber.org

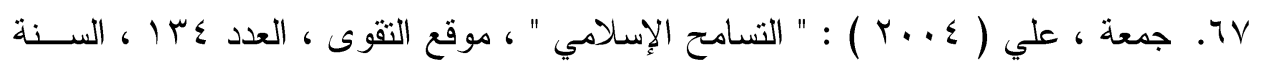
http://www.altakwa.net ro 1 4. حسنين ، أحمد جمعة (1910 ) : " دور كليات التزبية في تدعيم السلوك الــديمقر اطي لاى طلابها " ، رسالة ماجستير ، كلية التربية ، جامعة أسيوط .

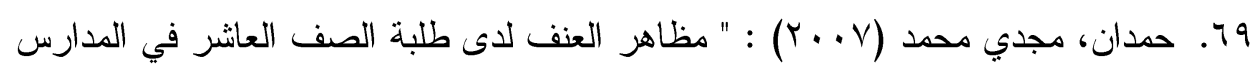

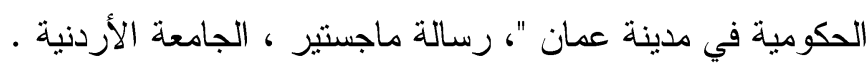

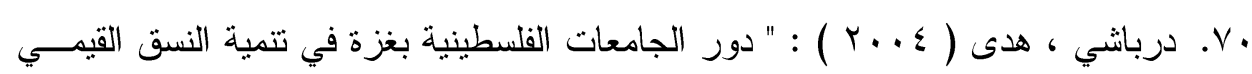
لدى الطلبة " ، رسالة دكتور اه ، برنامج الدراسات العليا المشترك ، كلية التربية بجامعة

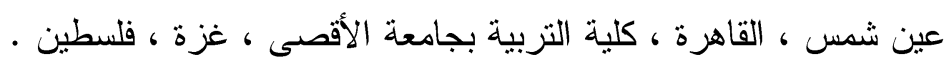
ا V. رضوان ، نادية ( 199V ) الثباب المصري المعاصر وأزمة القيم ، الهيئة المصــرية العامة للكتاب ، القاهرة .

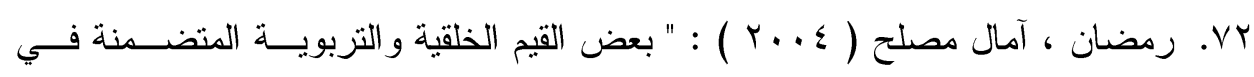
القصص القر آني ودورها في تربية النشء المسلم " ، مجلة كلية التربية ، جامعة عـين

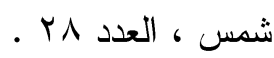
rV. زقزوق ، محمود حمدي ( r . . r ) : " التسامح في الإسلام " ، مجلة التسامح للار اسات الفكرية والإسلامية ، وزارة الأوقاف و الشُؤن الدينية ، سلطنة عمان .

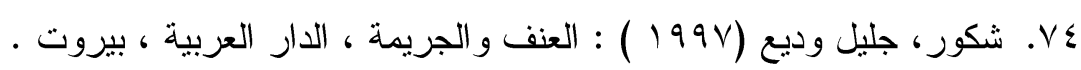

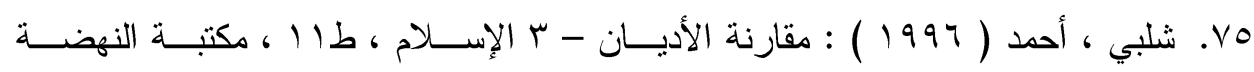

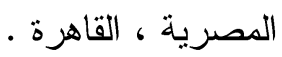

TY. شلق ، الفضل ( س 199 ) : الأمة و الدولة ، دار المنتخب ، بيروت .

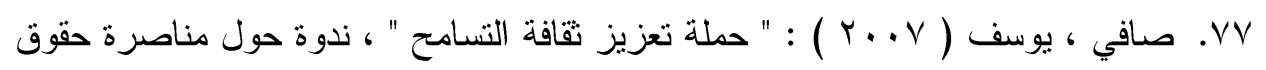
الثباب الفلسطيني ، جامعة القدس ، غزة ، فلسطين .

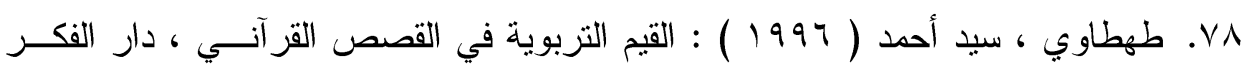

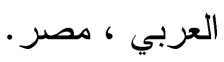


بعض قيم التسامح في الفكر التربوى الاسلامى وكيفية تعزيزها داخل الجامعات المصرية لمواجهة العنف المجتمعى آلمال

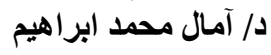

د/ نتسى أحمد فؤاد الدي

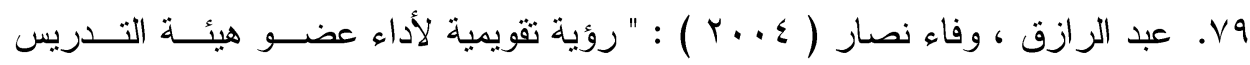
الجامعي في ضوء كل من أهداف مؤسسات التعليم الجامعي و التحديات " ، ندوة تتميــة أعضاء هيئة التدريس في مؤسسات التعليم العالي و التحديات و التطوير ، كلية التربية ، جامعة الملك سعود ، المملكة العربية السعودية . ماهية • ^. عبد الرحمن ، سعد ( . ( ) ) : عملية التطبيع الاجتماعي وأزمات التعصب و التحامل في مجتمعاتتا المعاصرة ، عالم الفكر ، الكويت .

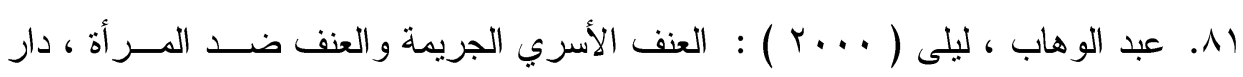
المدى للثقافة و النشر ، بيروت . لو هابث r. علوان ، عبد الله ( •191 ) : معالم الحضارة في الإسلام و أثزها في النهضة الأوربية ، دار السلام ، بيروت . سم. عوف ، ميرفت ( V. . . ) : " بفعل الاحتلال و الاقتتال جامعات فلسطين تصنع شــباباً

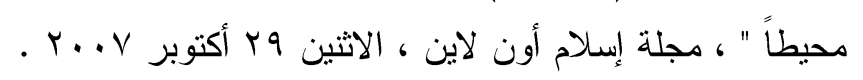
عـ. قر اعة ، محمود علي ( س79 19 ) : الأخلاق في الإسلام - من أحاديث الرســول ومــن فتاوي ابن تيمية ، مكتبة مصر الفجالة ، القاهرة .

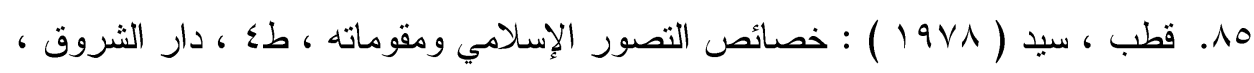
القاهرة .

؟1. مجمع اللغة العربية ( 1991 ) : المعجم الوسيط ، طب ، القاهرة . AV. محفوظ ، محمد ( ؟ . . F ) : " التسامح وجذور اللاتسامح - معنى التسامح و آفاق السلم

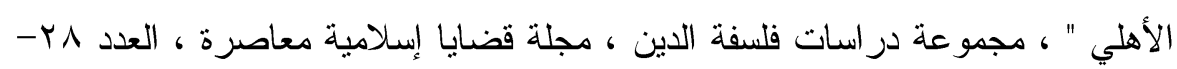

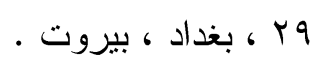
1^. محمد ، عبد الر اضي إير اهيم ( 1919 ) : " موقع القيم من بعض القلسفات " ، در اسات

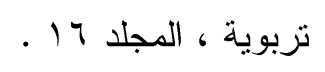

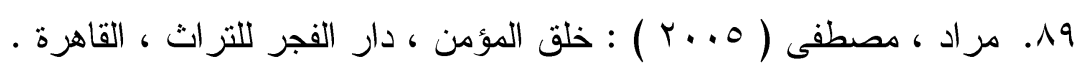
• 9. مكتب التربية العربي لدول الخليج ( ع^هو ) ) : " ماذا يريد التربويون من الإعلاميين " ، جم ، رسالة الخليج العربي ، الرياض ، المملكة العربية السعودية . ا9. منظمة الأمم المتحدة للتربية و العلم و الثقافة اليونسـكو (1990 ) : " "وثيقــة إعـلان اليونسكو حول التسامح " ، المؤتمر العام لليونسكو في دورته می ب ، باريس ، فرنسا. r. http://www.iraqlights.org العراق ، شبكة البرلمان العر اقي 
بعض قيم التسامح في الفكر التربوى الاسلامى وكيفية تعزيزها داخل الجامعات المصرية لمواجهة العنف المجتمعى

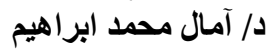

د/ نتسى أحمد فؤاد الترك التريو

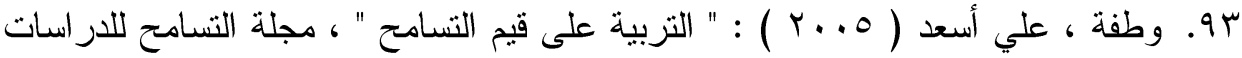

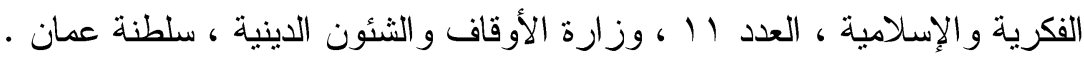

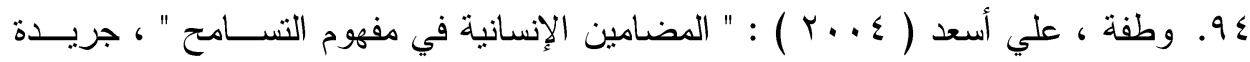

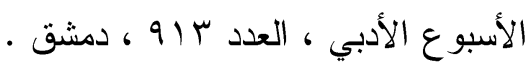

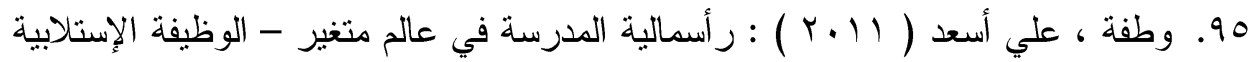
للعنف الرمزي و المناهج الخفية ، اتحاد الكتاب العرب ، سوريا.

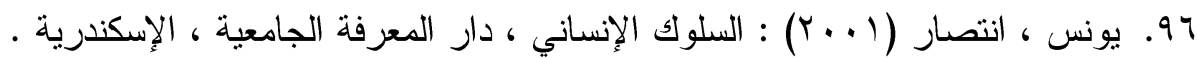

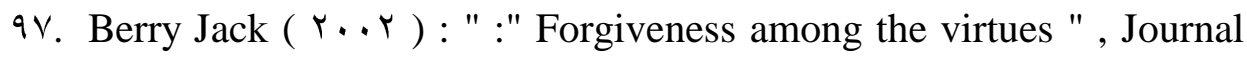
of Leadership , Organizational Studies . vol 9,No 1

9^. Lawler Kathleen $($ r..०) : The unique effects of forgiveness on health , An exploration of pathways, The university of Tennessee , Klawer@utk.edu

99. Leper, Sarah Hammond, et - al , ( 1919 ) : " Goods Schools for young children fifth Edition, Macmillan Publishing Company, New York .

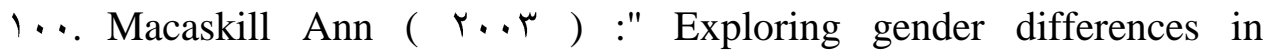
forgiveness ", Sheffield Hall am University .

1.1. Maselko Joanna ( $r \ldots r)$ : " Forgiveness is associated with psychological health " ,findings from the social survey Harvard School of public health.

1.r. Mecullough Michal $(r \ldots r): "$ Forgiveness is change ", Department of psychology and Religions studies, University of Miami .

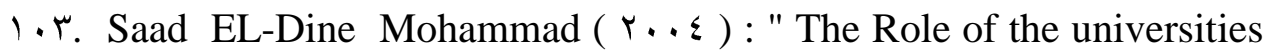
in fostering the Islamic - Christian mutual living and Dialogue ", central European University ( CEU ), Budapest, Hungary, $I r$ and ir November Y... .

1. . Tangney June (,$\ldots$. ) : " For giving the self conceptual issues and empirical findings " , Ed .Handbook of forgiveness, George Manson University .

1.0. Voltaire ( $197 \varepsilon)$ : Dictionnaire philosophique , GarnierFlammarion, Paris . 